IMISCOE

RESEARCH

\title{
Labour Migration
}

in Malaysia and Spain

Markets, Citizenship and Rights

BLANCA GARCÉS-MASCAREÑAS 
Labour Migration in Malaysia and Spain 


\section{IMISCOE \\ International Migration, Integration and Social Cohesion in Europe}

The IMISCOE Research Network unites researchers from, at present, 28 institutes specialising in studies of international migration, integration and social cohesion in Europe. What began in 2004 as a Network of Excellence sponsored by the Sixth Framework Programme of the European Commission has become, as of April 2009, an independent self-funding endeavour. From the start, IMISCOE has promoted integrated, multidisciplinary and globally comparative research led by scholars from various branches of the economic and social sciences, the humanities and law. The Network furthers existing studies and pioneers new scholarship on migration and migrant integration. Encouraging innovative lines of inquiry key to European policymaking and governance is also a priority.

The IMISCOE-Amsterdam University Press Series makes the Network's findings and results available to researchers, policymakers and practitioners, the media and other interested stakeholders. High-quality manuscripts authored by Network members and cooperating partners are evaluated by external peer reviews and the IMISCOE Editorial Committee. The Committee comprises the following members:

Tiziana Caponio, Department of Political Studies, University of Turin / Forum for International and European Research on Immigration (FIERI), Turin, Italy

Michael Collyer, Sussex Centre for Migration Research (SCMR), University of Sussex, United Kingdom

Rosita Fibbi, Swiss Forum for Migration and Population Studies (SFM), University of Neuchâtel / Institute of Social Sciences, University of Lausanne, Switzerland

Agata Górny, Centre of Migration Research (CMR) / Faculty of Economic Sciences, University of Warsaw, Poland

Albert Kraler, International Centre for Migration Policy Development (ICMPD), Vienna, Austria

Leo Lucassen, Institute of History, Leiden University, The Netherlands

Jorge Malheiros, Centre of Geographical Studies (CEG), University of Lisbon, Portugal

Marco Martiniello, National Fund for Scientific Research (FNRS), Brussels / Center for Ethnic and Migration Studies (CEDEM), University of Liège, Belgium

Patrick Simon, National Demographic Institute (INED), Paris, France

Miri Song, School of Social Policy and Sociology, University of Kent, United Kingdom

More information and how to join the Network can be found at www.imiscoe.org. 


\title{
Labour Migration in Malaysia and Spain
}

\author{
Markets, Citizenship and Rights
}

Blanca Garcés-Mascareñas

IMISCOE Research

Amsterdam UNiversity Press 
Cover design: Studio Jan de Boer BNO, Amsterdam Automated lay-out: Philos ${ }^{\circledR}$

$\begin{array}{ll}\text { ISBN } & 9789089642868 \\ \text { e-ISBN } & 9789048513628 \\ \text { NUR } & 741 / 763\end{array}$

(C) Blanca Garcés-Mascareñas / Amsterdam University Press, Amsterdam 2012

All rights reserved. Without limiting the rights under copyright reserved above, no part of this book may be reproduced, stored in or introduced into a retrieval system, or transmitted, in any form or by any means (electronic, mechanical, photocopying, recording or otherwise) without the written permission of both the copyright owner and the author of the book. 
C'est l'Etat qui se pense lui-même en pensant l'immigration, qui se pense selon la 'pensée d'Etat'

(Sayad i994: 164) 



\section{Table of contents}

Acknowledgements 9

Preface $\quad$ I3

$\begin{array}{ll}\text { I Regulating labour migration } & \text { I7 }\end{array}$

$\begin{array}{ll}\text { I.I The state } & \text { I7 }\end{array}$

$\begin{array}{ll}\text { I.2 Markets I9 } & \text { I9 }\end{array}$

I.3 Citizenship 22

I.4 Rights $\quad 26$

I.5 Migration policies 29

I.6 Law and illegal migration $3 \mathrm{I}$

$2 \quad$ Research design and methodology 35

2.I Research questions $\quad 35$

2.2 Case selection $\quad 37$

2.3 Elements of analysis 39

2.4 Methodological approach 4I

2.5 Fieldwork in two sites 45

3 Malaysia 49

3.I Introduction 49

3.2 Exporting goods, importing labour $\quad 5 \mathrm{I}$

3.3 Towards a guestworker policy 58

$\begin{array}{ll}3.4 & \text { Letting them in... } \\ & 64\end{array}$

3.5 ... but only as foreigners $\quad 74$

3.6 Turning illegal migrants into guestworkers 84

3.7 Detaining and deporting 'illegals' 93

3.8 Final remarks IOI

4 Spain 105

4.I Introduction $\quad$ I05

$\begin{array}{ll}\text { 4.2 From emigration to immigration } & \text { I07 }\end{array}$

4.3 From emigration control to immigration policies II5

4.4 Restricting entry $\quad$ I22

4.5 Between guestworkers and citizens $\quad$ I35 
4.6 Regularisation: an entry policy?

4.7 Deportation from within and from without

4.8 Final remarks

5 Comparative perspective $\quad 177$

5.I Towards closure $\quad 177$

5.2 The market response $\quad$ I80

5.3 Rights' constraints $\quad 185$

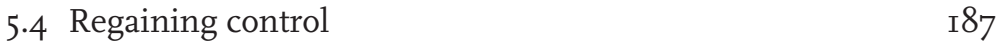

5.5 Final exclusion $\quad$ I90

6 Conclusions $\quad$ I95

6.I State response to labour demands $\quad$ I95

6.2 Markets, citizenship and rights $\quad$ I98

6.3 The illusion of migration 'management' 202

6.4 The state's production of illegality 205

6.5 Meanings of illegality 208

6.6 Towards a theory of borders and confines 210

$\begin{array}{ll}\text { References } & 2 \mathrm{I} 3\end{array}$

Annex I: Maps of Malaysia and Spain 230

Annex 2: Acronyms 232

Annex 3: Migration policies 233

Annex 4: List of interviews 239

Annex 5: Graph of immigration trends by nationality in Spain 243

$\begin{array}{ll}\text { Notes } & 244\end{array}$ 


\section{Acknowledgements}

People say that writing a book is a long journey, a journey that often begins long before it is dreamed. They also say that, like other journeys, a book never happens alone. While the responsibility for what is written is not shared, the path leading to its being written is shared. Without prior research, without sources, without uncomfortable questions and without confidantes to share the process of research with - as well as the life that always goes with it - the result would not be the same. Better said, it would be much poorer. In the case of this book, both tenets hold true. Hence, I begin by naming places and people.

Looking back, I'd say that it all began with my mother's thesis, which was also about migration. Hers concerned Catalan emigration to Puerto Rico in the nineteenth century. Her father, my grandfather, was part of that emigration, although he went to Puerto Rico half a century later, during the early years of Franco's dictatorship. Like so many other emigrants, my grandfather went alone, worked, sent letters and money, and never returned. Years later, my mother retraced his footsteps with her study. My sister and I traced her trajectory from Barcelona, hearing her stories and, on her return, helping organise all the information she had gathered about emigrants, origins and destinations.

It is thus no accident that I studied history. During my student years, I reaffirmed an interest in Latin America and deepened my knowledge of this part of the world. I also came upon two new realms: anthropology and Africa. The former was something I discovered with Sandra, Jaume, Joan, Ana and Marc. The latter, with Jordi, Joan, Carme, Albert and Jordi. With them, I learned and took pleasure in learning and, I am happy to say, still do. Without them and everything we shared, I would never have reached this point.

The difficulty of choosing from among these worlds - those experienced at home and those discovered at university - took me to Brazil, which I thought would be the perfect place for me. It was halfway between America and Africa and had a significant anthropological tradition. Destiny intervened and I had to return home. But in Brazil I met Wouter with him I would emigrate to the Netherlands years later. Without him, and thus without my Brazilian sojourn, Amsterdam would never have appeared on my map of possibilities. 
At the University of Amsterdam, I completed a Master's degree in migration and ethnic studies at the International School for Humanities and Social Science (ISHSS). Without a grant from the Caja Madrid Foundation, this would not have been possible. This was an intense time, as I discovered two more new worlds: the field of migration studies and South-East Asia. I was not alone in this, either. I express my gratitude to Myriam, with whom I explored Amsterdam and shared readings and studies throughout this first year. I missed her afterwards. I am eternally grateful to Leo Lucassen, who not only supervised my Master's thesis, but imbued in me an interest in academic research and encouraged me to continue with a PhD.

Guided by Leo, I met my PhD supervisors: Rinus Penninx, Kees Groenendijk and Jeroen Doomernik. I say in all sincerity that I could never have imagined better mentors. During these four years, we would regularly meet to discuss my work at Utrecht Centraal, in the train station's Hoog Brabant café. French anthropologist Marc Augé would call this a non-place (non-lieu), which is to say a space of transit where everything passes through, where nobody stays, where there is no structure except pure becoming. It was precisely in this non-place where my dissertation took shape. It did so thanks to my supervisors' criticisms as well as their support, interest and confidence in me. If I have any regrets about finishing my PhD, it is that I no longer have an excuse for our café meetups.

Behind my directors has been the constant presence of the Institute for Migration and Ethnic Studies (IMES) at the University of Amsterdam. I would like, first of all, to thank Jan Rath and Hanneke Grotenbreg for their support and belief in my project. Next, I thank each and every one of my colleagues. Although it took time, I ended up feeling at home. In different ways, they all shared these four years of research with me. I am also thankful to Tesseltje de Lange, whose comments on my work were crucial at both the beginning and the end of my PhD. Finally, I experienced, suffered and eventually celebrated with María Bruquetas and Lisa Peters the end of our three theses. Without them, it would have all been very different.

My thanks also go to everyone who assisted the two phases of fieldwork. In Malaysia, I thank Professor Shamsul for his institutional support and help in organising the Asia Europe Foundation (ASEF) workshop in 2008. In academic terms, feedback from Diana Wong and Patrick Pillai were invaluable. I am infinitely grateful for their interest and attention. Infinite, too, is the appreciation for my sources, all of whom generously gave of their time and trust. Whatever their points of view, they were willing to express and explain them. Finally, my warmest thanks go to David and Ruth, and Patrick and Carmel. They made me feel at home and shared their world with me. I hope that I shall be able to share mine with them.

In Spain, I was fortunate to receive help from Lorenzo Cachón and Ana 
López Sala. Here my indebtedness is twofold: for their guidance in my fieldwork and for thinking of me on so many other occasions. A thousand thanks to both. In Spain, too, I thank each and every one of my sources. Once again, I was given much more time and trust than I imagined I would receive and, contrary to expectations, was pleased to find many of the people I interviewed in unions, employer's organisations, government departments and NGOs were women. Finally, I give thanks to María's parents, Carlos and Nane, for the warm welcome they gave us in their home while doing my fieldwork in Madrid.

Upon conclusion of the $\mathrm{PhD}$, I received invaluable advice, constructive criticism and pertinent suggestions from my defence committee members: Hans van Amersfoort, Joaquín Arango, Leo Lucassen, Willem van Schendel and Diana Wong. I'm very thankful to each of them. The same goes for the three reviewers of this book, whose detailed comments helped improve the manuscript - to reach this final result. If they hadn't been anonymous, I would have loved to thank them directly, to reply and discuss further.

I am also greatly indebted to Julie Wark, whose English went where mine was unable to go. If writing in a language that is not one's own is always difficult and often frustrating, doing so in the company of a very good editor and translator who is also knowledgeable in the subject makes the experience stimulating and enriching. She has my deep gratitude for that. I also need to thank Karina Hof; her thorough proofreading and final corrections have greatly improved this work, checking for the last hidden Spanish expressions and making the English more lively.

Naturally, none of this would have been possible without funding. In chronological order of their support, I am beholden to the following institutions for enabling this research: Spanish Agency of International Development Cooperation (AECI) (2005-2007), Netherlands Organisation for Scientific Research (NWO) (2006), Centre for Migration Law (CMR) at Radboud Universiteit Nijmengen (2008), Institute for Migration and Ethnic Studies (IMES) at University of Amsterdam (2008-2009) and Jaume Bofill Foundation (2009).

I cannot conclude without naming the people I am so lucky to have with me in everyday life: my sister, Marina, and her Santi, Amanda and Ícar; my father, Jordi; my grandmother, Concepció; Isabel; my in-laws, Joke and Ton; and my friends, all of them, but with particular appreciation for those who have wanted to accompany me in this endeavour as well: María B. in Amsterdam and Laia, Jordi, Hug, Raquel, Sandra and Marc in Barcelona. Last but not least, this journey would not have been what it was without Wouter. Although the book was written by me, the adventure was shared by us. More than gratitude, for him I feel a sense of extraordinary fortune: I could not have a better companion for sharing my life, journeys and dreams. 
Finally, I dedicate this to my mother, Tona, with whom I cannot share this book and whom I continue to miss day after day. This journey would have been unimaginable without her. Since I am indebted to you for the dream, this book is both for and because of you. T'agradaria. 


\section{Preface}

Everyone is talking about globalisation. From different viewpoints, more or less critical stances and emphasising some aspects more than others, we all seem to agree that we live in an increasingly globalised world. This is to say a world characterised by the emergence of global dynamics and institutions and a progressive denationalisation of what, until very recently, had been constructed as national and from the national sphere. In economics, this has been characterised by the emergence of productive and financial markets on the world scale. In politics, it points to the construction of international regimes that regulate spheres ranging from international trade and intergovernmental relations through to intellectual property and human rights. In the social domain, a consolidating worldwide articulation of struggles and social conflicts is a point of reference. As for the cultural realm, warning voices identify the appearance of a uniform culture or great melting pot on the global scale. While this discussion of globalisation is notable for its diversity, there seems to be a common denominator: different points of view depart from the conviction that national confines and frontiers have undergone great change.

This certainty has marked a major part of present-day debates in the field of migration studies. First, several scholars have noted that the state is 'losing control'. Arguments refer to the growing gap between the intent of immigration policy and the reality of immigration. One explanation has focused on the impossibility of continuing to apply 'old rules of the game' and, more specifically, on the growing contradiction between (new) border-free economic spaces and (old) border control (Cornelius, Martin \& Hollifield I994, 2004; Sassen I995). Second, others point to the emergence of post-national forms of citizenship. From this standpoint, the establishment of an international human rights regime after World War II is seen to have led to the formulation of a set of citizenship rights defined and defended beyond the confines of the nation-state (Soysal I994; Bauböck I994; Sassen 2002). Finally, more recent studies stress transnational practices of the migrants themselves (Glick Schiller, Basch \& Blanc I992, I995; Portes I999, 2001, 2003; Faist 2000). Dubbed by Faist (2000) 'the third generation of migration scholarship', these studies focus on how the daily practices of migrants construct social spaces (or simultaneous multi-stranded social relations) that weave together their 
country of origin and their country of settlement. From this perspective, the practices of migrants (aided by new means of communication and transport) are seen as the main challenge to the confines of the national.

While these approaches have contributed significant nuances to the meaning and implications of present-day migration processes, their emphasis on the decline of the national and the rise of the post-national or transnational contrasts with the actual experience of migrants or travellers coming from the South. Contrary to what a 'globalised' world would seem to be suggesting, for them, the border looms as an evermore ubiquitous impasse. The first frontier rears up before they even depart. By means of more stringent visa requirements and extending the need for a visa to more countries, the state attempts to exert control over aspiring migrants (even when they are still beyond its national borders) by checking their identity documents, economic resources, reasons for the journey and motives for leaving or staying. The second barrier appears at the point of entry. For those who come in as tourists via airports and ports, it is a question of demonstrating once again that they do not intend to stay. For people who cross the geographic frontier, it is a matter of surviving deserts, seas and forests that increasingly end in blockades. Finally, although this fact is frequently overlooked, the border does not disappear once the migrant has entered the country. This is where the third - less tangible but no less decisive - frontier comes into action. It is one constructed on the basis of excluding those who are not authorised to remain (illegal immigrants) or including, albeit conditionally or partially, those who have just arrived (temporary residents).

This study arises precisely from the belief that this other face of reality should not be overlooked. At a time when immigration studies, particularly in social science, highlights the effects of globalisation on migratory processes, this research takes off from the conviction that it is also necessary to describe and explain the processes of border closure. This is not a question of either/or. Neither is it a matter of determining whether the frontier will succeed in imposing itself upon post-national and transnational realities or vice versa. They are not mutually excluding processes. The aim here is to change focus: while a considerable part of today's research discusses the global aspects of migratory processes, this study endeavours to elucidate the national or state side of these same processes. It starts with a twofold question. First, how can these frontiers be explained, i.e. what is the reason for the construction of all these walls and gates? Second, what effects do these frontiers have on migration flows? To answer these questions - which, rather than research questions are actually starting points - this study departs from the assumption that factors leading to channelling of immigration are never monolithic or unidirectional. I will therefore pay particular attention to the dilemmas and contradictions that underlie them. The present research is also guided by the 
conviction that the regulation of immigration not only involves analysing documents and policies, but also their implementation and effects. As this book will show, only then is it possible to understand how different circumstances are really dealt with in practice.

Besides accounting for the mechanisms of border regulation and closure defined and implemented by the nation-state, this study also responds to an urgent need to re-think the possibilities and limits of migration control in liberal democracies. In recent years, scholars such as Freeman (I995), Hollifield (I992, 2005), Joppke (I998a, I998b, I999) and Guiraudon (I998, 2000, 2002) have indicated that liberal democracies are self-constrained by rights. As pointed out by Joppke (I998b: 290): 'accepting immigration is inherent in the liberalness of liberal states'. From this standpoint, the gap between policy goals and policy effects would be the result not so much of the processes of globalisation, but of the difficulties liberal democracies face when it comes to excluding migrants who are already inside their national territory. While these studies have offered greater understanding of the political and legal processes underlying the 'doing' of immigration policies, their scope is still markedly limited: their analysis of migration control in liberal democracies is done from within - in other words, comparing liberal democracies with other liberal democracies. It is these constraints that led me to study Malaysia, as an example of a non-liberal state, and, from there, to consider to what extent we are looking at dynamics that are fundamentally different.

Having advanced the two main questions that explain the origins of this study, I now turn to outlining the structure of the book. Chapter I delimits the theoretical framework underpinning the study. This involves explaining what is understood by the terms 'state' and 'immigration policy', while also sketching out the contradictions lying at the basis of state regulation of labour immigration. The chapter covers both the main assumptions from which the research takes off and the most important theoretical issues to be resolved. Chapter 2 presents the research questions, the research design (including here the reasons for my choice of comparison), the methodological approach and the main challenges of fieldwork carried out in such dissimilar worlds. Chapters 3 and 4 describe the cases of Malaysia and Spain, respectively. Detailed analysis is given of the regulation of labour immigration in both countries from the ig8os through to 2007. My reason for analysing the two separately - acknowledging this is indeed a comparative work - was not wanting to interrupt the logic of each case and to facilitate reading for anyone who is especially interested in either of the two. Chapter 5 consists of a systematic comparison between state regulation of labour immigration in Malaysia and Spain. My analysis probes deepest at this point. Conclusions of the study are given in chapter 6. More specifical- 
ly, it is here that I directly address my research questions and deal with theoretical issues begging for a response from chapter I. 


\section{Regulating labour migration}

\subsection{The state}

While the concept of the state has always been central to political discourse and political analysis, until the I990s theories of international migration paid little attention to the role of the state in this domain (see Zolberg I999). Since the central focus has been on the forces driving migration flows (why people migrate), theories of international migration have mainly referred to: I) the structural forces in developing societies that promote emigration; 2) the structural forces in developed societies that attract immigration; 3 ) the motivations and goals of migrants themselves; and 4) the social and economic structures that connect emigration and immigration areas (Massey 1999: 304-305). However, in the wake of Zolberg's claims, a body of literature has developed since the late i990s to examine the role of the state in international migration flows. One of the key questions underlying these studies has been: what accounts for state choices with regard to migration policies?

From a society-centred perspective, immigration policies have been analysed as the outcome of a political process characterised by competition between different interest groups within the bureaucratic, legislative, judicial and public arenas (ibid.: 307). By positing the causal primacy and political dominance of forces in civil society, this approach confines the role of the state to that of the simple broker passively reacting to the claims of different interest groups or to merely finding some utility-maximising compromise between organised interests (Boswell 2007: 79). Classic examples of this approach are seen in Shughart, Tollison and Kimenyi (I986) and Freeman (I995). In the former study, three key interest groups are identified in the political competition to formulate immigration policy: while local workers would struggle to limit the supply of labour, capitalists would favour expanding it to reduce wages and keep labour markets flexible, and landowners would join them in this effort as a means of increasing their rent revenues. In a similar vein, Freeman (1995) argues that the migration policymaking process is primarily determined by those groups that champion a liberal immigration policy (mainly, employers and immigrant groups) and, to a lesser degree, by those who oppose it (the local 
workforce and people living in neighbourhoods where immigrants settle).

From a state-centred perspective, immigration policies have been explained as a state-engendered product. The state is thus seen as enjoying substantial autonomy in the formulation and implementation of preferences that are independent of societal interests. In the I960s and I970s, a first set of Marxist-oriented studies presented the state as operating in the interests of the economic elite (instrumentalists) or in the long-term interests of capitalists, independent of their degree of participation in the policymaking process (structuralists). ${ }^{\mathrm{I}}$ In fact, their conclusions were not so different from those stressed by a society-centred perspective. In both cases, the state has basically been presented as responding to economic imperatives or, in more straightforward terms, as existing 'to serve the needs of capital' (Purcell \& Nevins 2005: 215). Two criticisms could be made here. First, this argument is based on 'the teleological fallacy of deducing purpose or cause directly from outcome' (Calavita I989: 8I6). The fact that outcomes end up responding to the 'needs of capital' does not necessarily mean that this was actually the intention of policies. Second, the empirical evidence does not always correspond with such conclusions. If states always served the demands of capital, it might be argued that there would be no need for restrictive migration policies.

In recent years, a second set of studies, from a state-centred perspective, has looked at other political imperatives influencing state decisions on migration policies. Calavita's (I992: 9) study of the United States Immigration and Naturalization Service's role in the implementation of the Bracero Program, which 'imported' temporary contract labourers from Mexico from I942 until I964, observed how state institutions and bureaucracies are pervaded by structural contradictions that, depending on the location of these institutions within the state apparatus, lead to different dilemmas and responses. ${ }^{2}$ More recently, regarding the build-up of USMexico border enforcement in the I990s, Purcell and Nevins (2005) have noted that migration policies also respond to the need to preserve what they call the state-citizen relation, or the political legitimacy of the state in the eyes of its citizens. They suggest that what led to increasing border enforcement was the need to demonstrate to citizens that state actors were working to secure perceived citizen interests such as territorial security, a level of public services, labour market protection and a preservation of national identity. Finally, from a more comprehensive perspective, Boswell (2007) has developed what she defines as a 'theory of the functional imperatives of the state'. Her starting point is that the government must carry out certain tasks that are sometimes questioned (or tend to contradict to each other) in the field of migration policy.

Boswell (ibid.) identifies four tasks to be fulfilled by liberal welfare states. They are: I) to provide international and internal security for its citizens (security); 2) to contribute to economic growth and accumulation 
(accumulation); 3) to promote a just pattern of distribution and protect the privileged rights of its nationals (fairness); and 4) to conform to certain formal conditions considered vital for the preservation of democracy and liberty (institutional legitimacy). Boswell's approach brings out the inherent tension between the state imperative to promote economic growth (accumulation) and that of protecting citizens' privileged rights (security and fairness). Moreover, unlike other contemporary scholars (Sassen, Soysal, Hollifield, Joppke, Guiraudon), she does not conceive of rights as constraining a state's capacity from without - under the watch of international human rights regimes or legal institutions - but from within - because the state's legitimacy depends on its respecting its own laws and rights. Finally, by identifying the tasks of the state and assuming the difficulty of carrying them out simultaneously, Boswell concludes that the fundamental question is no longer one of elucidating to whom or what states respond when formulating and implementing migration policies, but rather how states manage to reconcile these conflicting demands (Boswell 2007: 92).

The present study takes up Boswell's question as its starting point and, in particular, the assumption that the state is obliged to respond simultaneously to contradictory demands in the field of migration control. The main difference from Boswell's approach is in the way in which state imperatives are labelled and identified. Instead of accumulation, I shall refer to the factor of markets, by which I mean the need to respond to employers' demands for foreign labour. Instead of security and fairness, I use the term 'citizenship', which refers to the state-citizen relation as defined by Purcell and Nevins (2005). This shift from the concepts of security and fairness to that of citizenship aims to broaden the scope to include those demands for closure that respond not only to the demand for migration control or for limiting the access to socio-economic resources, but also to other political requirements such as protection of the national labour market or the defence of cultural or ethnic homogeneity. Finally, what Boswell calls institutional legitimacy is here called rights. In this case, the difference is more in the terms than in the content. My preference for the term 'rights' seeks to link the present research to the existing literature that discusses the extent to which rights constrain liberal states in their capacity to regulate and control migration flows.

\subsection{Markets}

The term 'markets' has often been used to refer to the demand for foreign labour in receiving societies. As defined by Portes (I978: 47I-482) and Sassen (Sassen-Koob I978: 516-518; Sassen I988: 27), labour demands result from any situation in which the characteristics of the labour supply threaten existing or foreseeable levels of accumulation. Labour demands, 
then, do not always result from absolute labour shortages. Employers have also welcomed immigrants as a cheap and flexible labour force. That is, as a way of reducing the unitary cost of labour (by lowering wages) and increasing its flexibility (Portes \& Walton I981: 4; Sassen I988: 26; Zolberg I999: 83). This explains why the demand for foreign labour does not necessarily drop in contexts of large-scale unemployment.

It would be mistaken to assume that the demand for foreign labour is exclusively characteristic of industrial economies. The supply of labour in large quantities and over long distances has been a constant since the very beginnings of the world economic system in the sixteenth century. African slavery, Asian indentured servitude and the migration of millions of European peasants who moved to agrarian colonies are part of the first phase in the world market for labour power. Although these migration stories have hardly been studied together, scholars working in the field of historical migration studies have recently shown that they have more similarities than previously assumed (Lucassen 2007). In particular, McKeown (2004) has observed that transatlantic migration and Asian migration in the nineteenth century are not only comparable in volume, but respond to the ups and downs of the same global economic structure. Furthermore, contrary to widely shared notions of free and unfree labour migration, coerced migration of white Europeans (for example, convicts) did take place (see Bosma 2004), while most Chinese migrants were free and moved through personal networks of family and friends (McKeown 2004).

The second phase began with industrialisation and, for the first time, involved Europe as a destination area from abroad. From a Marxist perspective, the importation of labour in industrial societies has been explained as a means of lowering the costs of labour and reproduction of the workforce. Similarly, it has been portrayed as a buffer against seasonal or circumstantial downturns by exporting unemployment through the repatriation of immigrants or avoiding payment of unemployment compensation (Castles \& Kossack I973; Castells I975; Sassen I988). In explaining the structural demand for foreign labour, the dual labour markets theory has referred to the segmented character of the labour market (see Piore 1979), or the dichotomy between a capital-intensive primary sector, where most native workers are found, and a labour-intensive, low-productivity secondary sector, filled mainly by migrant workers. The reluctance of local workers to occupy 'unattractive' jobs cannot be disentangled from rising educational levels, increasingly negative attitudes towards unskilled manual labour and social welfare systems. In contrast, migrant workers would be more willing to accept such jobs because low wages in destination countries tend to be higher than those back home and the status and prestige that count for them have little to do with social expectations in the receiving societies (see e.g. Berger \& Mohr 1975). 
After 1973, the transnationalisation of capital and relocation of production plants to developing countries led to economic restructuring and a shift in foreign-labour demands in the so-called developed countries. Since then, immigrants were no longer required as blue-collar workers in leading industries, but rather to provide labour for low-wage jobs in the service sector. Sassen (I988, I99I) has identified two areas in which immigrant workers have been increasingly in demand in the global economies. First, they tend to be concentrated in low-paid jobs servicing the high-income lifestyles of a newly emergent group of high-income professional/technical workers. This includes, for instance, jobs preparing specialty and gourmet foods, producing decorative items, luxury clothing or other personal goods, or providing for cleaning, repair and other services. Second, immigrant workers have also been in great demand in the consumer sector catering to the population at large and in the downgraded manufacturing sector such as sweatshops and industrial homework.

In this context, the increasing presence of female immigrants in the care sector has been highlighted (see e.g. Chang 2000; Parreñas 200I; Ezquerra 2008). This 'international transfer of caretaking', in Parreñas' (2000) words, means that paid reproductive labour has moved into the international sphere. If, in the past, this work was done by low-paid women 'of colour' or from rural areas, today it is performed by immigrant women within a global system. Terms such as 'nanny chain', 'love chain' or 'global care chain' suggest that this transfer of caretaking is three-tiered: class-privileged women enlist the low-wage services of migrant women, which enables them to pursue salaried jobs without having to contend with the 'second shift' at home; migrant women simultaneously enlist the even lower-wage services of poorer women left behind in their homelands, with this local transfer of caretaking making their migration possible (Chang 2006:4I). This has notably been so in those welfare regimes where the state does not provide a comprehensive set of social services (for instance, caring for children or the aged), leaving households (mainly comprising women) to perform these functions. This leads Sciortino (2002) to conclude that, in contexts of rising activity rates among women and ageing populations, labour demands in the care sector are the product of specific welfare regimes.

As described in this section, labour demands are directly related with migration flows. First, Africans, Asians and Europeans migrated (or were forced to migrate) to work in the emerging colonial economies. Then new kinds of labour demands beckoned Southern European, Moroccans and Turks to migrate to Western Europe to work in its industrial and construction sectors. Mexicans, too, felt the tug when they left their hometowns to work as braceros (literally invoking the men's brazos, Spanish for 'arms') in the fields of the American agriculture industry, as waiters in urban restaurants, or producing all kinds of cottage-industry items. Neither 
should we forget the millions of workers from the Middle East and Asia who have been migrating to the Gulf countries since the I980s to fill all kinds of vacancies in the private sector. Or the thousands of Indonesians, Filipinos, Bangladeshis and Nepalese who can be found in the newly industrialised countries of Asia, working on plantations and construction sites, in factories, households and other services.

It would be erroneous, though, to assume all labour migrants move freely in response to push and pull factors. Or, that they answer the siren song of labour demands in receiving countries. As Zolberg notes (I999: 73), we should not forget that international migration flows through gates and these gates are flanked by high walls. In other words, legislative obstacles - beyond, at and within national borders - seek to obstruct entry and membership. While the benefits of foreign labour in capitalist economies have been extensively analysed by Marxist and global-economy theorists, what remains to be answered is the following: if foreign labour has played such a crucial role in colonial, industrial and post-industrial economies, why has labour mobility been restricted? In Zolberg's words (I989: 409): "given the advantages of an "unlimited supply of labour", why don't capitalists deploy their clout to import many, many more, or even to obtain completely open borders?' Any attempt to answer this question calls for a good look at the walls built up around an increasingly inclusive, and accordingly increasingly exclusive, definition of citizenship.

\subsection{Citizenship}

While citizenship means full inclusion in the national community (see Marshall I992), it also becomes a mechanism of closure when confronted with immigration (Brubaker I992: 2I-34). As pointed out by Bader (I995: 2I2), the tendency towards universalist inclusion within states has been, and still is, intrinsically interwoven with systematic exclusion of those categorised as non-members, non-citizens or foreigners. This means that while nation-states tend to be inclusive and democratic on the inside, they are apt to be exclusionary and undemocratic with regard to the outside (Joppke I999: 2). The externally exclusive dimension of citizenship has led to restrictions being applied to entry into the national territory and/or membership.

The restrictions enforced with regard to entry and stay, or territorial closure, cannot be extricated from a second key dimension of the nationstate: sovereignty. As noted by Joppke (ibid.: 5), state sovereignty makes territory rather than persons the primary reference point of rule. Before the modern nation-state, rule was exercised over particular sets of persons rather than over territories. The simple presence of foreigners did not entail political, administrative or legal inclusion. When it came to labour 
migration, African slaves and Asian indentured servants, in particular, could be brought permanently to the colonies without posing many challenges to the polity. Even if they settled, they had no access to membership. They remained foreigners or outsiders all their lives. By contrast, national state sovereignty leads to the identification of community or polity with territory. Consequently, the simple presence of foreigners within the territory is seen as a potential threat to the economic, social, political and cultural boundaries of the nation-state.

The response to this perceived threat has been a building up of visible and invisible walls in all these domains. In the labour market, migrants have often been seen as competing with local workers. They have been perceived as unfair competitors who tend to accept lower wages and working conditions, and even displace local workers within the labour market. Organised labour has therefore tended to demand some degree of closure, which mainly turns into market protection by means of imposing strictures on labour importation (see Penninx \& Roosblad 2000). Like national labour markets, welfare states are also perceived as being compelled to demonstrate some degree of closure (Guiraudon 2000: 74). Walzer (I983: 3I) states that 'the idea of distributive justice presupposes a bounded world within which distributions take place: a group of people committed to dividing, exchanging, and sharing social goods, first of all among themselves'. This has led, once more, to the drawing of solid boundaries between members of the community (entitled to social rights and services) and non-members (not entitled). There is general consensus that only by restricting the 'clientele' towards whom a state is responsible (Van Amersfoort 200I: I60; 2008: 7), is it possible to construct a 'kind of safe house in which to shelter its members from the outside world' (Freeman I986: 52) and prevent it 'from going bankrupt' (Joppke I998a: 7).

Some degree of closure has also been perceived as necessary for democracy. ${ }^{3}$ As noted by Bader (2005: 348), democratic decision-making presupposes well-defined and relatively stable rules of membership (voters versus non-voters) and democratic culture and trust. Despite being unrelated to limited resources, such as social services, political membership has been one of the most impermeable boundaries of the nation-state. This explains why, in contrast to economic and social rights, full political rights have only been given in case of full legal citizenship status. Finally, the nation-state is built on the principle that political and cultural boundaries should be congruent. Citizenship is therefore not only a legal status that bestows on its holders particular economic, social and political rights. Citizenship is also a form of identity that tends to be defined in terms of cultural homogeneity (see Kymlicka \& Norman I994: 369). This is why international migration has often been seen as a threat to the 'imagined community' (Anderson I983), namely, to its 
perceived linguistic, religious, ethnic and cultural homogeneity. And, here again, closure is deemed to be intrinsic to the nation-state.

Given the demands for closure in and around nation-states, it becomes clear that what makes immigrants suitable as (cheap and flexible) labour renders them undesirable from the perspective of membership in the receiving society (Zolberg I989:4II). The question, then, is: how did states deal with an apparently intractable dilemma between the demand for foreign labour and the demand for closed membership? Historically, this predicament has been solved - or attempted to be solved - by the introduction of guestworker programmes (see Garcés-Mascareñas 2004). These programmes allowed import of labour in the terms defined by markets. Employers could then recruit as many migrant workers as they wanted. At the same time, the demand for closure was satisfied by restricting membership instead of entry. First, this has been done by curtailing the economic, social and political rights of migrants. For instance, their mobility within the labour market has often been limited to a particular economic sector or even employer; or, they have often had no access to certain social provisions. Second, their stay can only be temporary. The expectation of repatriation or return is in fact what distinguishes guestworkers from former forms of labour transfers: while slaves belonged to an employer until the end of their lives and indentured servants were generally encouraged to stay after their contracts expired, guestworkers are, by definition, 'guests' who are expected to leave (Hahamovitch 2003: 72).

Guestworker programmes are thus the result of a state-fashioned compromise aimed at maintaining high levels of labour migration, while also strictly regulating immigration and closing national borders. The first wave of guestworker programmes was grounded particularly in the process of institutionalising the idea of the nation-state as a prospectively homogeneous ethnocultural unit (Torpey 2000: 2I-56). Prussia embarked on state-sanctioned temporary migration in I890 with Polish-speaking immigrants who fuelled the rise of German nationalism (Herbert I990: I8-34; Lucassen 2005: 50-73). Similarly, in the first decades of the twentieth century, a migrant labour system was put in place to supply foreign labour to the diamond and gold mines of southern Africa, with a view to importing a large, malleable labour force while simultaneously placating whites who wanted hermetic segregation from non-whites (Hahamovitch 2003: 76). This uncomfortable cohabitation between foreign labour and national closure was to become a more widespread phenomenon during the two World Wars. As Harris (I995: 6) points out, war exacerbated xenophobia while at once requiring a boost in manpower to maximise wartime production. This compelled countries such as France, the United Kingdom, Germany and the US to set up temporary foreign labour schemes. 
After World War II, new guestworker programmes were implemented in Europe (the UK, France, ${ }^{4}$ Switzerland, Belgium, the Netherlands and West Germany) and the US. This second wave was not only the result of demands to preserve cultural unity, but also a response to the expanding attributions of the social state (Garcés-Mascareñas 2004: 3). First, as shown by Lucassen (I998), increasing welfare arrangements led the state to become more interested in protecting the national labour market so as to avoid unemployment among national workers. The growing political importance of the labour movement also explains the increasing protection of the national labour market. This led post-war guestworker programmes to adapt immigrant presence to the fluctuating labour demands and to concentrate migrant workers within a secondary labour market. Second, the rise of welfare states in the twentieth century fostered the tightening-up of borders in another sense. As said before, the more states promised their citizens in terms of services (workers' compensation, oldage and child benefits, public education, etc.), the more urgent it became to curtail or, at least in practice, to identify who was eligible for these services and who was not. The upshot was a gradual demand to exclude foreigners from the long-term benefits of the welfare state.

Since the ig8os, guestworker programmes have also accompanied the economic boom in the countries of South-East Asia and the Middle East, bringing in large numbers of high- and low-skilled workers. These new labour schemes have become increasingly feminised as a consequence of the so-called 'maid trade'. Moreover, the sending governments have played a more important role, not only controlling labour transactions, but also marketing - in the Philippines, for instance - their citizens abroad (Hahamovitch 2003: 89).

While temporary labour schemes have continued in non-Western countries, by the I970s and I980s, there was general consensus that guestworker programmes had 'failed' since there was nothing more permanent than 'temporary' foreign workers (Martin 2000). The settlement of guestworkers in receiving societies has been explained by the fact that migrants, unlike goods and capital, were entitled to certain rights under the aegis of liberal constitutions (see Hollifield i992). As the Swiss novelist Max Frisch writes, European governments had 'asked for workers but human beings came' (in Hollifield 2005). By virtue of their humanity, guestworkers were entitled to social, welfare and eventually residence rights. The guestworker's status as a human being and therefore as the subject of rights clashed with the formula of 'open entry' yet 'closed membership'. In a context of rights, the compromise between markets and citizenship was thus a mirage (Martin \& Teitelbaum 200I) or proved to be an illusionary solution (Papademetriou, Martin \& Miller I983) in the long run. 


\section{$1.4 \quad$ Rights}

In the context of migration, civil and human rights translate into limitations on the state's capacity to exclude foreigners. This is basically because civil and human rights are not citizenship rights, strictly speaking. Unlike the latter, the former are guaranteed not only to state members, but to all foreigners (Sassen I996: 89; Joppke I998a: 71; Bader 2005: 348). As they are bestowed on individuals qua persons rather than qua citizens - or, in other words, as they turn any individual into an object of the law and a locus of rights - civil and human rights can sabotage restrictive policies, thus counteracting the external exclusive dimension of citizenship.

Several scholars have signalled the extent to which human rights constrain state sovereignty and particularly its right to decide who enters and who does not, or who is an insider and who is not. The approach of these scholars varies in the way they define the source of these rights. First, scholars such as Soysal (I994) and Sassen (I996) have explained rights constraints on the state's sovereignty by the rise of an international human rights regime based on international agreements and conventions enshrining the rights of migrant workers or the status of refugees, which, they argue, would protect migrants regardless of their nationality. According to these authors, although there are no global mechanisms to guarantee the rights conferred by international conventions, the emergence of the individual as the object of international law and the growing ability of NGOs and individuals to make claims on the basis of international human rights instruments would have gradually forced states to be accountable not only to its citizens, but also to all its residents.

Other scholars such as Hollifield (I992, 2005), Joppke (I998a, I998b, I999) and Guiraudon (I998, 2000, 2002) have understood rights limitations as being internally rather than externally produced. They emphasise how all Western constitutions enshrine a catalogue of elementary human rights that, together with strong and independent judiciaries, would hamper state capacity to restrict immigration. This is basically because any draconian measure in liberal states may be challenged and overturned by the courts as unconstitutional or as a violation of civil rights. From a historical perspective, these authors refer to nationally defined rights and the role of courts to explain the extension of social and residence rights to post-war guestworkers and their families, as well as the admission of major refugee flows in Western Europe from the I980s onwards. From a more theoretical perspective, this brings them to the conclusion that rights constraints do not result from declining sovereignty in an increasingly globalised world, but rather from the functioning of the legal system (or rule of law) in liberal states. As Joppke (I998b: 290) notes in a seemingly tautological sentence: 'accepting unwanted immigration is inherent in the liberalness of liberal states'. Similarly, Hollifield (2000: I48) has referred 
to what he calls the 'liberal state thesis', or the notion that 'rights' (beyond push-pull and social network factors) are a key explanatory factor for the persistence of international migration to liberal states.

Freeman (I995) began from a similar observation when he noticed that, contrary to the widespread rhetoric of restrictionism, the politics of immigration in liberal democracies is 'broadly expansionist and inclusive'. However, he identifies the political process, rather than the legal system, as the major factor of self-limited sovereignty in liberal states, arguing that their immigration policy is characterised by a 'client politics' and a universalistic idiom of liberalism that prevents political elites from playing the ethnicity or race card. In this context, he explains the expansionist, inclusive character of immigration policies by the fact that, while the benefits of immigration (such as cheap labour and - from the immigrant's perspective - reunited families) are concentrated, its costs (such as increased social expenses or rising population) are diffuse. Freeman's argument suggests that such a distribution of costs and benefits would lead policymakers to be more responsive to their immigration-advocating clients (employers and immigrant groups) than to the more ambivalent if not hostile general public.

Though constituting a first important step in attempts to clarify the logic of immigration policy within the political process of liberal democracies, Freeman's work has been severely criticised. Three main disputations are worth mentioning here. First, Brubaker (I995) observes that many of the trends identified by Freeman are either a general feature of migration or a 'particular feature of particular discursive fields'. Thus, Brubaker argues, some of the features are either to be found in other political systems or are the result of a cultural-political story about particular times and places. Second, Joppke (1998a: 19-20) points out that Freeman's approach to immigration policy as client politics seems to work better in settler societies, where immigration coincided with nationbuilding. By contrast, in European societies, where immigration postdated nation-building, Joppke finds immigration politics more likely to have been guided by a restrictionist national interest. Finally, Freeman does not identify the legal process as a separate source of expansiveness and inclusiveness toward immigrants. This is particularly problematic if we recall (see Guiraudon I998, 2000) that social rights for immigrants were not only achieved in the open arena of democracy, where different interest groups may have a say, but also behind the closed doors of bureaucracy and the courtroom.

Discussion on the limits of migration control in liberal democracies or the dilemma between citizenship and rights - has been central in most political analyses on migration policies. More recently, from a quite different perspective, the economists Ruhs and Martin (2006) have signalled that low-skilled migration in high-income countries inevitably entails a 
trade-off between numbers and rights, arguing that the more rights lowskilled migrants have, the less advantageous (or desirable) they are. ${ }^{5}$ Two basic reasons for this are forwarded. First, if low-skilled migrants have the right to equal wages and all work-related benefits, their cost is higher and therefore fewer will be employed. The other side of the coin is that fewer and more limited migrant rights mean lower costs for employers and more migrants employed (ibid.: 7 ). Second, there is the suggestion that migrants with lower-than-average incomes tend to pay less in taxes and, because of their lower incomes, may be eligible for more government-funded services. Although this is up for discussion, ${ }^{6}$ Ruhs and Martin conclude (ibid. 8 ) that, in order to minimise the fiscal costs of low-skilled migrants, highincome countries may limit migrant numbers or their access to welfare benefits.

Ruhs and Martin suggest that a key point regarding the role of rights in labour migration is that (low-skilled) migrants are desirable as long as their presence is restricted. If liberal states are self-constrained by rights and cannot therefore limit migrants' membership, this would imply that these states are de facto compelled to adhere to a policy of low numbers and high rights. By this logic, countries with few rights constraints would be more inclined to admit numerically significant labour migration flows, as they seem to have more ways of excluding newcomers and hence shoring up the bulwark that protects citizenship. In fact, this same argument is implicit in the typology of different models of immigration suggested by Arango (2003: 3). Leaving aside what we might call the traditional countries of immigration (the US, Canada, Australia and New Zealand), Arango distinguishes between democratic and non-democratic or autocratic societies. The former would recognise moral and political obligations vis-à-vis the immigrants while attempting to keep the numbers admitted as low as possible; the latter would tend to have no compunctions about letting in large numbers of people, though only on the condition that they be temporary labourers with limited rights. In brief, to recall the words of Ruhs and Martin (2006), the former would restrict numbers while the latter would restrict rights.

Although no systematic research has been done on these issues regarding less liberal states or non-Western countries, these are common assumptions among many Western scholars (see Hollifield I992: 32; Hollifield 2005: 26; Ruhs \& Martin 2006: 10). However, two sets of questions arise from these conclusions. The first refers to liberal democracies. Did liberal democracies, after the end of post-war guestworker programmes, really opt for a policy of low numbers and high rights? If so, to what extent did the policy succeed in a context of high labour demands? That is, could liberal democracies disregard the market factor in order to comply with the demands for closure and rights' constraints? The second set of questions refers to less-liberal or non-Western states. To what extent can 
these countries choose a policy of low rights? What, then, is the role of the international human rights regime as defined by Soysal and Sassen? If we accept that in these countries membership can be much more limited because the state is not - or at least less - constrained by rights and courts, to what extent do they succeed in turning migrants into pure labour? To what extent can they really - not only by law, but also in practice - open entry while restricting membership? Finally, in contrast with liberal democracies, to what extent can they solve the dilemma, if there is one, between markets and citizenship?

Another issue to consider is the role of illegal migration. One venerable and well-documented proposition holds that illegal migration serves to create and sustain a legally vulnerable, thus tractable and cheap, reserve of labour (see inter alia Galarza I964; Castells I975; Bustamante I976; Burawoy I976; Jenkins I978; Piore I979; Portes \& Walton I98I; Sassen I988; Calavita I990; De Genova 2002). Sassen (I988: 36) points out that '[...] border enforcement is a mechanism facilitating the extraction of cheap labour by assigning criminal status to a segment of the working class illegal immigrants'. This leads to two immediate questions regarding the limits of migration control in liberal democracies. On the one hand, we might wonder to what extent illegal migration is a way of having a de facto policy of high numbers and low rights in liberal states. Since illegal migrants do not officially exist, to what extent does their presence allow liberal states to practice a policy of open borders but closed membership and thereby solve the contradictions between markets and citizenship and between citizenship and rights? On the other hand, illegal 'migrant beings' are also 'human beings' and theoretically - at least in the international canon - have civil and human rights. Thus, how far can liberal states go in more or less ignoring the presence of illegal migrants and therefore restricting their rights and membership in society? That is, how far are liberal democracies constrained by rights when dealing with illegal migration?

\subsection{Migration policies}

If state migration policies' choices are analysed as a result of the conflicting demands between markets, citizenship and rights, the next step is to clarify what migration policies are. Following Hammar's (I985) definition, immigration policy regulates the entry and stay of foreigners, whereas immigrant policy is concerned with their integration into host societies. While this definition is commonly accepted, what remains unresolved is the question of where policy starts and where it ends. In this regard, many scholars seem to assume that policies are primarily and fundamentally policy documents or 'stated policy objectives' (see e.g. Cornelius \& Tsuda 
2004: 5). This narrow definition of migration policies suggests that migration policymaking is understood as the formulation of rules and procedures, while their implementation and outcomes are processes that would seem to start where policy ends, often forcing changes in its content.

This clear-cut distinction between policymaking, stated policy goals (normally understood as policy as a whole), policy implementation and policy outcomes is what underlies the oft-cited policy gap (ibid.: 4-I5). Although often mixed up, two different kinds of policy gaps have been identified. First, some scholars have observed a gap between public and policymakers at the decision-making stage. For instance, Freeman (I995) notes a discrepancy between the desires of a largely anti-immigration public and the expansive bias of policies, which would be formulated under direct pressure from employers and immigrant groups. Another example of this approach is Joppke (I998b), who explains the gap between restrictionist rhetoric and an expansionist reality by referring to the selflimited sovereignty of liberal democracies. Second, other scholars have identified a gap between policy goals and outputs. According to Cornelius and Tsuda (2004: 5$)$, this gap would result from inadequate policy implementation or enforcement and its unintended effects. In more specific terms, this gap is explained by four main factors: I) reliance on policy instruments with inherent flaws; 2) macro-structural processes, such as the structural demand for migrant workers or cross-national disparities and transnational economic and social ties; 3) domestic and international constraints, which link up with Freeman's and Joppke's interpretations; and 4) ambiguous policy intentions.

Why governments continue to rely on flawed policies and the main ambiguities underlying migration policies are rarely explained. Despite these unresolved questions, many scholars conclude that the persistent gap between policy objectives and outcomes - dubbed an 'empirical fact' by Cornelius and Tsuda (2004: 5) - proves that the state is loosing control (Sassen I996), that migration flows are far beyond the states' capacity for control (Massey I998) and that policies do not always matter (Thielemann 2003). There could be objection, however, that, at least in part, such conclusions arise from the definition of the problem and particularly from the initial distinction between policymaking, policy goals, implementation and outcomes. If we expand the notion of policy on the whole, so as to embrace policymaking, implementation and outcomes, the resulting picture would almost certainly be substantially different. That is, by making this shift from the part to the whole, the question is no longer why policies do not succeed in their purpose or why outcomes differ from stated official goals, but rather why policies as a whole (on paper and in practice) are riddled with inconsistencies, contradictions and inefficiencies. This inferred question is central to this book. 


\subsection{Law and illegal migration}

To understand policy outcomes as part of the policy itself entails establishing a direct link between illegal migration and migration control. This link has already been observed by many scholars from a very different perspective. The most common approach has been to explain illegal immigration as a result of ineffective and powerless law. Internalising the mores and norms of the modern state by portraying the law as a force that bars illegal entry and sojourn, rather than as a process that defines who and what is illegal (Coutin I996: II), this approach focuses on the degree to which policies are capable of stemming illegal immigration. The conclusion is simple: illegal migration proves the ineffectiveness of migration policies because if it continues to 'take place' and 'illegal migrants' continue 'to be present' in contemporary societies, despite increasing border enforcement and more internal control, policies are evidently not working. This perceived failure of migration policies (or gap between policy goals and outcomes) is explained by high costs of enforcement, the economic role of illegal labour, public unwillingness to punish migrants' illegality or the powerful thrust of the macro-structural forces of migration (Cornelius \& Tsuda 2004: 9).

A second way of approaching the link between the law and illegal migration is by focusing on how the law serves the interests of powerful economic and political groups, basically needs of capitalists and capitalism. From this perspective, migration policies are not analysed in their attempt to reduce illegal migration, but rather in their function of placing illegal migrants in a more exploitable position. The criminalisation of illegal migrants is understood as a way of constructing and preserving the otherness on which the immigrants' condition as a cheap, flexible labour force rests (Bach I978: 537; Portes \& Bach I985: 474; Sassen I988: 7; Calavita 2005: 46). Finally, in a less deterministic way, more recent studies have opened up what we could call a third approach to the legal production of migrants' illegality (De Genova 2002; Coutin 2000, 2005). The question here is how immigration law constitutes individuals within immigration categories. In this regard, more effective migration policies do not mean less illegal migration (as assumed by the first set of studies), but rather that the state has refined its ability to set up categories of differentiation. The law thus creates the very subjects that, on the surface, it seeks to bar. Whether these subjects do in fact constitute a cheap and flexible labour force is more an empirical question than a starting point for inquiry.

If the law creates the category of 'illegal', the next question is what it means to be categorised as such. For Coutin (2000: 30), illegality means 'a space of forced invisibility, exclusion, subjugation and repression'. These forms of non-existence are imposed on migrants by mechanisms 
such as confining reality to that which can be documented; temporalisation of presence, where the possibility of regularisation depends on being able to prove illegal residence; 'legal aconsanguinity', in which certain kinship ties are nullified by immigration policies; 'enforced clandestinity'; and restricted physical and social mobility (ibid.: 30-33). Along similar lines, De Genova (2002: 438-439) defines migrant illegality as that space determined by a palpable sense of deportability, which is to say, the possibility of being removed from the space of the nation-state. What defines illegality is not deportation, per se, but rather the possibility of deportation. Even though only some are deported while most remain 'undeported', everyone is vulnerable. According to De Genova, this deportability reproduces the physical borders of nation-states in the migrants' everyday life and, in so doing, constructs a spatialised and racialised social condition that would certainly sustain the vulnerability and docility of illegal migrants as workers.

By focusing on the construction of 'illegality' as an immigration category, this third approach also reveals how immigrants turn the tables by using the law to claim, contest and reject these legal identities. In her study on Salvadorian migrants in the US, Coutin (2005: 23) observes how they challenge the attribution of illegality by arguing that they migrated to the US out of necessity, that they were participating and were therefore integrated into US society or that the US economy benefited from their labour. Similarly, Kyle and Siracusa (2005) show how Ecuadorian migrants in Spain were aware of breaking immigration law, but rejected the idea that this made their venture illegal. These migrants justified their stance by referring to the responsibility of the Ecuadorian state elite, defined as a powerful mafia running a predatory state, and to the historical responsibility of Spain as coloniser of Latin America. Using Van Schendel and Abraham's terms (2005), their main claim was that Salvadorians' movement and stay in Spain was illegal yet licit, that is, considered illegitimate by the state but claimed as legitimate by themselves. While these authors have noted how the attribution of illegality has been contested in migrant discourse, other scholars have focused on how individual and collective coping strategies of the migrants themselves, NGOs and sympathetic civil servants have opened loopholes for illegal immigrants in an increasingly protected job market and welfare state 7 (see e.g. Van der Leun 2003).

Although this approach has brought key insights to the contested meanings and implications of migrant illegality, it has shifted the focus away from the causes underlying illegal migration. The question that remains to be answered is how to explain illegal migration. Is it, as argued by Cornelius and Tsuda, the result of ineffective, failed or inherently flawed immigration policies? Is it, as Portes, Sassen and Calavita would have, a way of creating a cheap and flexible labour force? Or, in keeping with my own definition of migration policies, does illegal migration go hand in 
hand with the inconsistencies, contradictions and inefficiencies underlying migration policies? To be more precise, what is the causal relationship and to what extent is illegal migration a way of solving the contradictory demands of markets, citizenship and rights? And, if it works like this, to what extent does it meet these demands or, alternatively, pose new contradictions and dilemmas in the context of the nation-state, be it liberal or otherwise? 



\section{Research design and methodology}

\subsection{Research questions}

As the literature cited in chapter I would suggest, state regulation of labour migration is confronted with a double dilemma. First, while markets require a policy of open borders to provide as many foreign workers as employers demand, citizenship requires some degree of closure to the outside. Second, while the exclusive character of citizenship demands closed membership, civil and human rights would seem to undermine the state capacity (or, as some would believe, the state right) to exclude foreigners once they're in the country. In fact, rather than two separate dilemmas, the different factors involved shape a trilemma between markets, citizenship and rights. Their characteristics have been analysed in relation to specific historical events, for example, the introduction of guestworker programmes in Western Europe. As we have seen, several scholars have signalled that post-war guestworker programmes 'failed' because the attempt to resolve the dilemma between markets and citizenship was eventually challenged by rights. The dilemma between citizenship and rights has also been analysed with the focus on family migration and refugees in Western Europe from the I970s onwards. In particular, it has been pointed out that liberal democracies could not stop "unwanted migration' as they were constrained by an international human rights' regime, constitutional rights and national courts.

While the relationship between markets, citizenship and rights has dominated most analysis of migration policies, three key aspects have systematically been left out of the debate. First, little research has been done on the markets-citizenship-rights trilemma after I973. This may be explained by the fact that most studies focus on Western European countries, where the demand for foreign workers stopped (or is commonly thought to have stopped ${ }^{\mathrm{I}}$ ) with the oil crisis of 1973 . Second, research done in non-Western countries has scant presence in this discussion, so that little is known about the trilemma in other political settings. This lack of (more general) comparative research makes it difficult to disentangle as Brubaker (I995) observed regarding Freeman's work - what might be an exclusive feature of migration in liberal democracies from what could be deemed a feature of migration in general. Third and finally, this 
trilemma has almost exclusively referred to legal migration. However, illegal migration may result not only from the demand to create a flexible and cheap labour force, but also from the contradictions underlying labour migration. It has yet to be seen to what extent illegal migration is a way of coming to some kind of compromise or uneasy balance between markets, citizenship and rights, and to what extent this compromise is possible in the long run.

The present research aims to address these three lacunae in the literature by comparing labour migration regulations in Malaysia and Spain from the I980s onwards. The first question of this study is: how did the Malaysian and the Spanish states respond to the demand for foreign labour? This involves looking at how states regulated the entry and stay of labour migrants or how they determined the number of immigrants allowed to enter the country, their origins and conditions of entry. Moreover, it requires looking at how they defined the status of legal migrants once they were in the country, and what exactly their membership consisted of in all its political, social, economic and cultural forms. The question here is whether and why restrictions were imposed on the entry and/or membership of labour migrants and how this might have worked in practice. If labour demands are fulfilled by illegal migration, then the next question is to what extent rules on entry and stay explain the extension of illegal migration and how migrants are handled once they are categorised as illegal. Inquiry into the situation of illegal migrants and, in particular, whether they are partially excluded, recognised (to whatever extent) via regularisation programmes or expelled through deportation drives also sheds light on the matter of how labour demands are covered in practice in the short, mid and long run.

At a more theoretical level, the second question of this study is: what do Malaysia and Spain tell us about the relationship between markets, citizenship and rights? Both Malaysia and Spain have required huge inputs of foreign labour since the early I990s. The market factor would therefore seem to be similar in both cases. To be considered then is whether differences in terms of citizenship and rights lead to different arrangements, compromises and choices in the market-citizenship-rights trilemma. In the case of Malaysia, it remains to be seen whether 'weak citizenship', as defined by Sadiq (2005) (see next section), leads to open borders when it comes to both entry and membership. As for the role of rights, one important question that emerges is whether a less liberal state chooses a policy of high numbers and low rights and how this works in practice. In the case of Spain, one needs to ascertain, first, whether the Spanish state reached some kind of compromise or made a choice between the demand for foreign labour and the demand for closed membership. Second, it must be determined whether, given the role of rights and the rule of law in liberal states, the state chose (or was compelled to choose) a policy of 
low numbers and high rights and, if this was so, what this meant for markets.

\subsection{Case selection}

This study compares the policy responses to foreign labour demands in a non-Western and a Western nation-state. Taking a non-Western and a Western nation-state seeks to fill a lacuna in immigration research, which rarely ventures beyond Western countries - particularly Western Europe and North America. ${ }^{2}$ Going beyond the traditional geographies of comparative migration research, my aim is to consider to what extent liberal democracies are unique in dealing with labour migration, especially visà-vis the challenges that labour migration seems to present to the nationstate. The key issue is to discern what is specific to liberal democracies and what is not. Moreover, I believe that this dual focus makes it possible to reconsider concepts such as citizenship and rights, which have always been defined in relation to liberal democracies.

My main reason for choosing Malaysia and Spain is that they seem to be similar in terms of markets while differing in terms of citizenship and rights. Given their similar market conditions, comparing the two countries allows one to consider whether different features in terms of citizenship and rights lead to different policy approaches and outcomes. Saying they are similar in terms of markets means that both Malaysia and Spain have presented significant foreign labour demands since the r99os. In Malaysia, these labour demands have sprung from the unprecedented economic growth that started in the I970 as a consequence of highly centralised development planning and, more generally, the relocation of production plants from Western to developing countries. Spain's demand for foreign labour arose from unprecedented economic growth ever since the I990s, demographic decline and a gradual dualisation of the labour market.

Though having comparable markets, Malaysia and Spain differ in the matter of citizenship. Sadiq (2005: II3) has observed that, as in other developing countries such as India, Indonesia, Bangladesh, Thailand, Ecuador, Paraguay, Nigeria and Ghana, the distinction between citizens and non-citizens is largely meaningless in Malaysia. The main reason for this is what he calls weakly institutionalised citizenship, which is manifested in the lack of standardised documentation for its population and hence the impossibility of classifying, categorising and monitoring citizens and even distinguishing them from non-citizens. For Malaysia, Sadiq finds that weakly institutionalised citizenship would be used by elements within the Malaysian state to change the ethnic composition of the population, making it 'more Malay' vis-à-vis the Chinese and Indian popula- 
tions. Meanwhile, the distinction between citizens and non-citizens in Spain seems clearer. Sadiq's argument suggests that Spain would be expected to present a more institutionalised form of citizenship, as the state seems to be more capable of monitoring its citizens by means of a thoroughgoing system of identity cards, passports and different population registers. In addition, being a stronger welfare state and the fact that Spain is part of the European Union (as well as its southern border) would make the need to distinguish citizens from non-citizens even more imperious.

Malaysia and Spain are different when it comes to rights as well. While Spain fits into the category of a liberal democracy, Malaysia could be defined as a considerably less liberal, if not authoritarian, state. Lee (2003) notes a general consensus in Malaysia that some sacrifice of the benefits of rule of law is necessary to achieve economic and social advancement, the price that must be paid to have a strong and powerful executive government that will assure economic growth and social stability. Moreover, democracy and human rights are often presented as being alien to cultural norms and traditional values of Eastern societies. In this regard, one opposition member of Parliament stated, '... [W] henever the government is attacked for being "undemocratic", the standard reply is that democracy is a Western concept which has restricted relevance to an Asian context. More relevant is the concept (it is claimed) that people elect their government who then carry out whatever actions they see fit for the good of the people' (in Lee 2003: 244).

The disproportionate power of the Malaysian executive is illustrated by its constant resort to emergency powers. Since independence in I957, the country has been subject to some state of emergency most of the time. As denounced by the International Bar Council (2000): ' ... [T] he continuation of emergency after the need for it has passed [a reference to the Communist insurgency in 1948-1960, 1969-1989] can have an insidiously brutalising effect upon the administration of justice in any country. We suggest that the Malaysian malaise may be due in no small measure to the gradual acceptance of a state of emergency as the norm of Government.' Apart from its reliance on emergency powers, the government has introduced several laws that sought to curb human rights and freedoms. For example, the Internal Security Act (generally known as ISA, which was passed in 1960) gives sweeping powers to the executive (the police and the Ministry of Home Affairs) to arrest and detain any person for a period of 60 days, after which the minister can extend the detention period indefinitely (with renewals every two years) without trial or any right to legal advice or protection.

Comparison between Malaysia and Spain would thus seem relevant concerning similarities in markets and differences in citizenship and rights. The final aim of this research is thus to examine how, under similar conditions in terms of foreign labour demands, different features 
regarding citizenship and rights lead to different policy objectives and policy outcomes. As posed by Rose (I973: 68) in his article on the need for comparative policy studies, the question is: ' $[\mathrm{I}] \mathrm{n}$ what way, if any, do these institutional differences affect choices between policy alternatives, the implementation of policies or the effects of policies?' The answer to this simple yet fundamental question should enable us to understand migration policies and outcomes in relation to the challenges labour migration keeps throwing at the nation-state and particularly to the compromises or trade-offs responding to the trilemma of conflicting demands posed by markets, citizenship and rights.

\subsection{Elements of analysis}

To understand how the Malaysian and the Spanish states responded to demands for foreign labour, a focus on both migration regulation and migration control is needed. By migration regulation, I mean the way the state regulates labour migrants' entry and stay. I will consider how the state defines numbers and characteristics of migrants, their conditions of entry and their status once in the country, especially with regard to their position in the labour market, taxation of the payment they receive for their work and temporality of their permits. Speaking of migration control, I refer to how the state defines and responds to migrant illegality. I shall examine regularisation programmes and deportation campaigns. The term 'regularisation programmes' refers to any procedure by which nonnationals who are illegally resident or are otherwise in breach of national immigration rules are granted a legal status (see Baldwin-Edwards \& Kraler 2009: 7); 'deportation campaigns' includes all those measures aimed at eliminating this illegality by the draconian means of physically expelling illegal migrants from the country.

It might be argued that migration control is much more than a state's definition of, and response to, migrant illegality and that its scope is broader than regularisation programmes and deportation campaigns. Indeed, measures such as visa policies, border patrols and employers' sanctions are also part of migration control. However, these measures will not be taken as central elements of analysis. The reason is simple: given the limitations of any research, my particular focus on regularisation programmes and deportation campaigns allows a consideration not only of how the state attempts to control migration, but also to what extent it is constrained by rights when defining the boundaries of membership. From a rights perspective, it may be possible to exclude migrants before they leave their homelands, at the border or even within the labour market. However, from this same rights perspective, to what extent is it possible to ignore and exclude illegal migrants indefinitely, and to what extent can 
they be physically removed and sent back to their countries of origin? That is, in contrast to other migration control measures, analysis of regularisation programmes and deportation campaigns permits one to inquire more deeply into the conflicting demands between markets, citizenship and rights.

This study, then, focuses on four policy measures. They include: I) policies regulating labour migrants' entry; 2) policies regulating labour migrants' stay; 3) regularisation programmes; and 4) deportation campaigns. I shall analyse how and why these policy measures are formulated and implemented, and what their main effects are. In terms of formulation, the central issue is the set of reasons underlying the policymaking process. This leads to questions such as who decides the numbers and characteristics of labour migrants, to what extent and why entry or membership is restricted on paper, why there is a need for regularisation or why and when deportation campaigns are launched. These questions mean, first, that we need to understand policies not as 'natural instruments at our disposal', but as bearers of values, grounded in a certain interpretation of what constitutes the social and precise notions of the mode of regulation envisaged (Lascoumes \& Le Gales 2007: 4). Second, they also require one to scrutinise the different actors involved in the policymaking process. Here I shall consider not only the positions of the different ministries, institutions and political parties, but also those of pertinent social actors such as employers, trade unions, NGOs and migrant organisations. As both Sciortino (2000: 220) and Boswell (2007: 78) warn, ascertaining the interests of all these actors is not something one can take for granted, but rather analysis should be carried out in the light of specific policies and contexts.

As for implementation, in considering how these four policy measures actually work, I shall explore the relationship between policy as written and policy in practice. Apposite questions here are whether policies regulating migrants' entry and stay are implemented as they are supposed to, and how regularisation programmes and deportation campaigns are brought into practice. The relationship between policy on the books and the policy as applied, or the gap between, will be analysed in terms of political will and capacity. After all, not every policy may be meant to be successfully implemented, nor can all be successful. In some circumstances, we might find a mismatch between explicit and implicit policy goals. In others, policy practices might be constrained by a lack of resources, or they could clash with other policies or with the goals and actions of non-governmental actors (including the migrants themselves) involved in their implementation.

Finally, when it comes to policy effects, the focus should be on the meanings and consequences of policy goals and practices. By 'meanings', I refer to the ways in which these policies conjure up a specific represen- 
tation of reality or, to paraphrase Lascoumes and Le Gales (2007: 10), how they offer a framework for describing the social with a particular categorisation and problematisation of the situation addressed. In the context of this research, this means analysing how policies engender reality by fixing the terms of what a labour migrant or an illegal migrant is or should be. By 'consequences', I mean policy outcomes in terms of flows and stocks of immigrants or migrants' legal status. Many authors have distinguished between intended and unintended policy consequences. While the former are those effects that do in fact correspond with policy goals, the latter are unforeseen or foreseen albeit with unforeseen costs which, in the overall process, might appear as dilemmas or trade-offs (Brochmann \& Hammar I999: 20). As nicely stated by Zolberg (I999: 9I): ‘... [A]ffluent democracies [...] must either accept as a fact of life a certain level of unregulated immigration, over and above what they explicitly provide for in their immigration policies, or devise draconian policies that necessarily encroach on their political liberalism.'

The analysis of policy effects is relevant in two different ways. First, it allows one to go beyond policy goals and discourses and therefore elaborate a more complex and nuanced picture of migration policy models. For example, if restrictive entry policies result in illegal migration and this, in turn, leads to frequent regularisation programmes, then the policy model that results will be far from being as restrictive as initially envisaged. Second, policy effects constitute part of the context for further decisionmaking. If we take policy effects as part of the ongoing context for policymaking, then choices or compromises between the conflicting demands imposed by markets, citizenship and rights should not be taken as final decisions, but rather as particular decisions from particular moments. Following up on the previous example, a restrictive entry policy may indicate a state choosing to respond to demands for closed membership rather than to demands for foreign labour. However, if this policy results in an increase of illegal migration and the consequent introduction of frequent regularisation programmes, then the final result in terms of choices will turn out to be the opposite: a policy that responds to demands for foreign labour, rather than demands for closed membership.

\subsection{Methodological approach}

This book is, above all, comparative. As Hollifield (I992: I7) notes, this means more than a collection of national case studies with useful sources of information but few theoretical insights. 'Comparative' means explaining rather than describing (Sartori I994: I5) and, in this particular instance, explaining the quandaries that labour migration poses for the nation-state and how these translate into particular policies and policy 
outcomes. Some migration scholars have questioned the meaningfulness of cross-national comparisons by arguing that cases tend to be so dissimilar and complex that any attempt to discover commonalities and patterns of behaviour would have to be fatally flawed and, in particular, that national specificities thwart one's ability to generalise (Miller I986: 746). The starting point of this research is precisely the opposite. Only by comparing and, even more, by comparing what some would call the 'incomparable' (Detienne 2000), is it possible to formulate questions that otherwise would have never been considered and, by so doing, trace relationships and deconstruct categories that are all too often taken for granted in particular historical and national contexts (see Green I997). As Bloch (I953: 50I) well puts it: "[C]omparison is "a powerful magic wand" that allowed historians to see beyond local conditions to develop more comprehensive explanations.'

However, 'to explain by comparing' or to 'compare to explain' tends to imply a sacrifice of understanding in context and of context itself. There is a clear trade-off between the level of explanation and abstraction, and the depth and solidity of description (Landman 2003: I4, 46; Sartori I994: 24). This trade-off acquires greater dimensions when we increase the number of countries under study. The more countries we include, the more we may explain, but the less we may know about the specificities and context of each case. Given the intractability of the problem, this study seeks to reach a kind of compromise between these levels of explanation and description by opting for a two-country study. While comparing and therefore having an explanatory aim, a two-country study permits historical depth and thoroughgoing examination of both cases. However, its main weakness lies in its level of representativity or the extent to which it is possible to generalise from only two cases. For instance, to what extent can we assume that Malaysia and Spain are representative of other nonWestern and Western states? Malaysia and Spain might not be representative as policy models, but their comparison could serve to identify mechanisms and trends between specific variables. In particular, this comparison aims to draw conclusions (and hence generalise) on the role of citizenship and rights in a context of huge labour demands.

This research is also interdisciplinary. As observed by Brettell and Hollifield (2000: vii): '[M]igration is a subject that cries out for an interdisciplinary approach.' This was also pointed out by Castles (I993: 30) when he called for '[...] the study of migration as a social science in its own right [...] strongly multidisciplinary in its theory and methodology'. If we describe any interdisciplinary approach in terms of borrowings, we should then say that the main borrowings of this particular inquiry come from history and the political sciences. From history, this research has taken the diachronic perspective. As forwarded by Pierson (2004:2), any attempt to understand social processes requires placing politics in time and con- 
structing 'moving pictures rather than snapshots'. In keeping with this argument, the rules on migrants' entry and stay, regularisation programmes and deportation campaigns will be considered in their development since the Ig80s. History also matters not only for understanding how policies evolve over time, but also when pondering how they are constrained by previous (and subsequent) developments. To borrow North's words (I999: I37): '[H]istory is inherently path-dependent because constraints from the past impose limits on current choices.' Taking these constraints on choices into account, the cases of Malaysia and Spain will start with a historical overview (from the nineteenth century on) of both labour demands and migration policies.

Taken from political science, the main object of study here is the role of the nation-state in controlling migration flows and borders or, to rephrase the matter, the impact of sovereignty and citizenship on migration. In short, the state and its responses to labour migration drive this research. The state, as the history of political sciences shows, can be understood in very different ways. This study is grounded in a dialecticalstructural model of the state. Hence, the state will not be perceived as a neutral arena wherein different interest groups compete (pluralism), nor as an instrument of the economic elite (instrumentalism), nor as objectively linked to the interests of capital (structuralism), nor as constrained by institutions such as bureaucracies and courts (institutionalism). Instead, law and policy will be analysed as the state's attempts to resolve the conflicts issuing from underlying contradictions (Calavita I992: I74). As mentioned in chapter I, Boswell (2007: 89-9I) has described these underlying contradictions through four different functional imperatives of the state: security, accumulation, fairness and institutional legitimacy. In my work, these tensions or conflicting demands are identified in terms of markets, citizenship and rights. Whatever our differences in focus, the key question for both Boswell and myself is the same: in a context of conflicting demands, how does the state manage to reconcile them?

As for research methods, the main borrowings are once again from history and political science. From history, I learned to glean significant material from archival research. First, I perused the main national newspapers (especially Malaysia's New Straits Times and Spain's El País) from the mid-I980s onwards. I also surveyed other newspapers. My aim was to obtain official statements from the main stakeholders (politicians, employers, trade unions, migrant organisations) on particular policies and policy outcomes. These statements will be signalled by the use of italic font within quotation marks. From newspapers I also obtained official statistics on policy outcomes, for instance, figures showing how many migrants have been admitted, regularised or deported in a particular year. Second, parliamentary debates since the ig8os were also analysed. This applies only to the Spanish case since parliamentary discussions in 
Malaysia are not publicly available. Again, I sought statements from the main political parties and official statistics on policy outcomes. Finally, I reviewed all kinds of reports written by the main stakeholders, such as particular ministries or government departments, employers' organisations, trade unions, NGOs, and migrant and human rights organisations.

Besides this archival research, I borrowed from political science the technique of interviewing key stakeholders. I conducted 36 interviews in Malaysia and 37 in Spain (as itemised in Annex 4). Although these interviews did not allow me to delve too deeply into the past, they did permit me to capture significant nuances in policy outcomes and effects that were usually lost in the written documents. Interviews were semi-structured, meaning that, although they were based on a set of questions, the interviewee was free to focus on those questions that he or she found most relevant. The reason for giving the interviewee this leeway was twofold. First, the aim was to reduce the risk of bias that specific questions might introduce. Questions were therefore formulated to prompt open descriptions rather than confirmations of my own conclusions. This meant posing 'what' or 'how' rather than 'why' questions. Second, the semistructured interview was also conducive to building trust (which, in some cases, was only possible after several hours of 'conversation') and, by so doing, to obtain not only official statements, but also insights from offthe-cuff remarks (in many cases on illegal migration) - 'confessions' that could never have been made in a more formal setting.

The need to build up trust was another reason for not recording the interviews. While, in Malaysia, recording was out of the question, in Spain it would have changed the kind (and depth) out of the information obtained. As a consequence, the quotes - which again will be signalled by the use of italic font within quotation marks - come from transcriptions of notes I took during the interviews. It is important to specify that I have only quoted sentences that could be fully reproduced and, as a result, the quotes tend to be relatively brief. The attribution of quotes to interviewees is semi-anonymous, by which I mean that I only refer to an interviewee's affiliation and when and where the interview occurred. Maintaining some degree of anonymity seemed appropriate considering the sensitivity of some of the observations and, for that matter, the lack of relevancy in terms of 'who said what'. Finally, this research is also based on secondary scientific literature. The academic literature becomes particularly relevant as a backup when abstraction (and comparison) demands some sacrifice in terms of description. That is, any research done at a comparative, macrolevel tends to rely on previous research at a micro-level.

To recapitulate, this study is based on three different sets of sources: primary documents from archival research, interviews and secondary documents. The datasets were codified according to the four policy measures (rules on entry, rules on stay, regularisation programmes and de- 
portation campaigns) and time. When analysing the data and interpreting the events, I used the triangulation method (see Yin I994: 90-92) and therefore tried to base my observations on the various sources of data. However, this was not always possible since each kind of source provides different kinds of information. For example, from primary data I gathered information about policy measures from the I980s and I990s, but hardly any insight into how policies worked. By contrast, interviews provided a great deal of information about how present policies worked in practice, but almost no detail about policy measures from the past. Using different sources and research methods allowed me to contrast information in some cases and to complement it in others.

\subsection{Fieldwork in two sites}

To pursue the archival research and interviews and collect the main academic literature in each case (most of it only available locally), I spent six months in Malaysia (from July to November 2006, and from January to February 2008) and six months in Spain (from October to December 2007, and from March to May 2008). Starting with Malaysia, the more unknown terrain for me, allowed me to delve into the specificities of this country while keeping Spain in mind. Once I got more familiar with Malaysia, I could inquire into the case of Spain by contrasting my findings and, even more important, posing questions from the standpoint of new perspectives acquired from Malaysia. A need for continual contrast and comparison of one country with the other explains why I broke each part of the fieldwork into two periods: alternating Malaysia, Spain, Malaysia, Spain.

Of utmost importance, then, was my return to Malaysia after having embarked on fieldwork in Spain. This renewal of my first stretch of fieldwork in the country allowed me to pay attention to aspects that I had completely overlooked at the beginning and that only came to light during my fieldwork in Spain. Returning to Malaysia also permitted me to present my first findings to local migration scholars and stakeholders, under the auspices of an international workshop entitled 'Now You See Them, Now You Don't: Defining Irregular Migrants in Europe and Asia and the Immigration Measures Applied to Them'. ${ }^{3}$ One of the main criticisms I received from Malaysian scholars was that I stressed continuity rather than discontinuity. As I shall state below, this criticism is inseparable from the scope of our different kinds of research. Looking at Malaysia from outside, instead of focusing on its specificities, allows one to distinguish a unique migration model that, rather than changing, persists and reinforces itself over time.

While this toing and froing between fieldwork sites had positive out- 
comes, doing research in two different worlds also presented major difficulties and challenges. The first difficulty arose from meanings. For instance, the terms 'legality' and 'illegality', 'borders' and 'boundaries', 'inclusion' and 'exclusion' do not mean the same things in Malaysia and Spain. This hitch compelled me to pinpoint specific policy measures and, in so doing, to consider how they ended up constructing different realities. Another major stumbling block associated with two-sited fieldwork is data. One of the first facts to emerge from any comparative research is that methodology is contextually bound, which is to say that sources and research methods vary in each case. In Malaysia, as I have noted, migration policies are not discussed in Parliament or officially published. ${ }^{4}$ As a member of the Cabinet Committee for Foreign Workers stated: 'Migration policies are somewhere in the Ministry of Home Affairs but they are confidential, they are not accessible to the public' (interview 20 October 2006, Putrajaya). I thus had to rely almost exclusively on interviews and newspapers, which is where most press releases from the government are publicised. By contrast, in Spain, press sources could be complemented with parliamentary discussions, official documents and reports and other reports from the main stakeholders.

This difference in the existence and availability of official sources, compounded by a much more prolific academic literature in Spain, had an undeniable influence on quality and quantity of the data obtained. It is important to recognise the fact - without being able to change it - that there is an imbalance between the data obtained for both countries. This has been one of my main concerns and problems, not only during fieldwork, but also in the process of writing this book. Ultimately, I reached two main conclusions. First, part of the imbalance was resolved by other constraints: the case of Spain had to be limited anyway if I wanted to keep the narrative clear and not get lost in details that were not wholly relevant for the research. Second, I accepted the imbalance as an intrinsic part of my work. In general terms, I believe the imbalance affects neither my essential line of argument nor the potential to answer my research questions.

Another difference worthy of mention pertains to the stakeholders I interviewed. A glance at the list of interviews (see Annex 4) shows patent disparity. While in both countries, I interviewed people from the main government departments, employers organisations, trade unions and NGOs, some types of actors are unique to each case. For instance, due to their essential role, I interviewed several labour recruitment agencies in Malaysia. However, I did not interview members of the immigrant community here as I did in Spain. This was not out of negligence. As I shall show in chapter 3 , the temporality and restricted mobility of foreign labour in Malaysia undermines the capacity of these immigrants to negotiate for better conditions. As they cannot self-represent, migrants are mainly 
represented by their respective governments. Hence, embassies, rather than migrants' organisations, matter in Malaysia. In Spain, it is the other way around: embassies are not relevant and therefore remained beyond the scope of my interviews. Spanish migrants' organisations played a much more important role not only in the decision-making process, but particularly in policy implementation. Accordingly, I interviewed people from the most active immigrants' organisations in Barcelona and Madrid.

Also important is the question of representativity. Any comparative research runs the risk of obscuring the distinctive histories of regions and hence of homogenising differences under the rubric of the nation-state (Cohen 2004). As Tyrrell (I991: I032) has critically remarked, comparative research is all too often 'conceived to test purely national differences rather than convey a more varied sense of the elements that make up the diversity of historical experience'. My study does not set out to cover diversity within each case. In Malaysia all my interviews and most of the data obtained from the main national newspaper refer to Peninsular Malaysia and, more particularly, to the Klang Valley, an area in the state of Selangor in which Kuala Lumpur, its suburbs, and adjoining cities and towns are located. The reason for focusing on this area is that most 'foreign workers', as they are called in Malaysia, are to be found there. Nevertheless, we should not confuse the part with the whole. The situation in Peninsular Malaysia cannot be extended to all Malaysia. As I shall explain in chapter 3, the situation in eastern Malaysia (in the states of Sabah and Sarawak on the island of Borneo) is not comparable either in terms of migration flows or migration policies. Then again, in Spain, the interviews were done in Barcelona and Madrid. Both cities were chosen because they are key immigration areas. Moreover, Madrid proved inevitable, being the centre of any decision-making process at the national level. While in Spain, in contrast to Malaysia, we see a single immigration policy model, the way policies are implemented differs across regions, provinces and municipalities. Despite its not being central to my research, this diversity in policy implementation will be referred to when relevant.

Finally, as for methodology, the position of the researcher in any comparative study is contextually bound. In Malaysia, I was a complete outsider. Suffice it to say that nobody could guess my origins. Upon revelation that I held Spanish citizenship, most of the people I encountered immediately associated Spain with its Moorish history so that, to my surprise, many Malaysians (particularly those with Malay identity) identified Spain as a Muslim country. Although difficult to prove it, I would say that my little understood national status facilitated, rather than obstructed, my work. It might have made it easier to ask questions that would otherwise have been deemed too sensitive, and to approach people I might never have had access to, as a non-Malay and non-Malaysian scholar. The same logic applies to my research in Spain, though the other way around. 
Being a Catalan Spanish, my position was not neutral. While classifying everybody much more easily in Spain, I was more quickly classified myself. Moreover, my spectrum of possible questions was much more limited. I could not ask about things believed to be known by everybody or simply 'common sense'. When I did, I usually got no answer since, as my interviewees made evident, my question was thought to be rhetorical or just too obvious. This gave me the odd feeling that, in Spain, while being an insider, and therefore knowing much more in advance, I might have 'discovered' much less. 


\section{Malaysia}

\subsection{Introduction}

Immigration to Malaysia has mainly been explained in economic terms (Kanapathy 200I, 2004, 2006). The primarily adduced factors are the severe labour shortage generated by the country's continuous economic growth in the past three decades and the economic disparities between Malaysia and migrants' countries of origin. To illustrate, between 1987 and I993, I4 million new jobs were created in Malaysia at an average growth rate of 3.9 per cent as compared with an average domestic labour force growth rate of 3.I per cent. Labour shortages were particularly felt in manufacturing and construction, with an average employment creation growth rate of 9.8 per cent and 9.I per cent, respectively, for the same period (Moha Asri \& Moshidi I996: I2). Meanwhile, the average wage rate in Indonesia is three to ten times lower than in Malaysia (World Bank I995: 58-62 in Wong \& Anwar 2003: I70; Bagoes Mantra I999: 62). In macro-economic terms, Malaysia presents a gross domestic product per capita (\$US Io,882) which is twice as high as in the Philippines (\$US 5,I37), almost three times higher than in Indonesia and India (\$US 3,843 and \$US 3,452, respectively), four to five times higher than in Pakistan and Bangladesh (\$US 2,370 and \$US 2,053, respectively) and seven to ten times higher than in Nepal and Myanmar (\$US I,550 and \$ USI,027, respectively) (UN Human Development Report 2007/2008: 229-232).

But market factors alone are not enough to explain the actual magnitude, composition and distribution of labour migration to Malaysia. Geographic proximity between Sumatra and Peninsular Malaysia, between Kalimantan and Sarawak and between western Mindanao and Sabah provides many opportunities for border-crossing. From Indonesia or the Philippines, it is a mere two to four hours by boat ride. Other migrants arrive in Malaysia through the rain forests of Kalimantan or the green pastures of the Thai-Malaysian border (see Annex I, Map I). These borders are not only geographically contiguous, but have been historically porous. In pre-colonial times, the Malay Archipelago (which includes Indonesia and Malaysia) was a free, open migration area with seas, islands and shallow, narrow waterways that facilitated the movement of merchandise and people (Pillai 2005: 69). Migrants from Sumatra and Sulawesi 
began to settle in what is now Peninsular Malaysia from the mid-seventeenth century onwards. Although at the end of the nineteenth century colonialism divided the archipelago into separate territories (British Malaya and the Dutch East Indies), the British coined the category of 'Malay' - 'one who speaks the Malay language, professes Islam and habitually follows Malay customs' (Andaya \& Andaya ı982: 302) - which left the doors of migration open to culturally similar Indonesians.

This history of migration has also facilitated the making and remaking of close social ties on both sides of the border. Old migrants constitute a very important source of information about job opportunities and assistance for newly arrived in Malaysia. Friends, acquaintances and compatriots provide the new migrants with jobs, housing and other necessities. In this regard, old migrants bring new migrants, and returnee migrants encourage prospective migrants. Social networks thus feed and define the geographies of migration. In South-East Asia, these social networks are complemented by (and sometimes coincide with) recruitment agencies that formally or informally organise the whole migration process from rural areas in Indonesia, Bangladesh or the Philippines to a household in the Klang Valley, a factory in Penang or a construction site in Malacca. Since the business of these recruitment agencies depends on the number of migrant workers they are able to send to Malaysia, their presence must be understood not only as a way of channelling migration flows, but also as a mechanism that promotes them.

Together with geographic, historical and socio-economic factors, migration to Malaysia must also be understood within the tradition of travel in the South-East Asian archipelago. Called 'merantau' among the Minang of Sumatra or 'berjalai' among the Iban of Borneo, this tradition encourages young men to travel in search of experience and income before returning home to get married and settle down (Wong \& Anwar 2003: 197). Rantau, the root of 'merantuau', which literally means 'land outside the territory' -i.e. a foreign country - represents a place where you work hard, acquiring knowledge, skills and experience. Your success in rantau adds greatly to your security and happiness and that of your relatives and own home village or country (Wang I992: 169 in Pillai 2005: 69). Migration to Malaysia must thus be explained not only as a way of seeking better employment and wages or minimising the risk of poverty for the whole household, but also as a necessary rite of passage to adulthood. It is interesting to note how the tradition of travel in South-East Asia has fed the labour demands produced by early capitalism and, in the last decades, by the relocation of production plants from Western to developing countries. In other words, the tradition of travel in South-East Asia both facilitated and was facilitated by the development of capitalist economies in the region.

While all these factors explain migration flows to Malaysia, they 
hardly take into account the fact that international migration flows through gates, and that the gates are flanked by high walls (Zolberg I999: 73). This chapter, like the whole book, focuses on these gates and walls. It examines how the Malaysian state regulated the huge demand for migrant workers from I980 to 2007 . First, this means analysing how the state attempted to reconcile the conflicting demands underlying labour migration. Did the state respond exclusively to the demands for foreign labour? What were the main demands for closure and to what extent were they given response? And what was the role of rights? Did Malaysia, as often assumed by Western scholars, succeed in turning migrants into pure labour? Second, as addressed in chapter I, policies are much more than their documents. If we take the whole - policy formulation, its implementation and its effects - another question to be considered is whether and to what extent policies were fraught with inconsistencies, contradictions and inefficiencies. In particular, did policies succeed in their stated purposes?

With these two questions in mind, this chapter gives, first, an overview of the demand for migrant workers and the consequent growth of the immigrant population in Malaysia from colonial times to the present (section 3.2). Following this, I describe the main developments in terms of migration policies (section 3.3). Particular attention is given to the different dilemmas that immigration posed to the Malaysian state. This perspective takes up Wong's (2002: 3) suggestion that any comparative account of contemporary 'global' migration would have to begin with the substantive genealogy of the states concerned, rather than merely assume the comparability of their abstract territorial forms. This account of migration policies will also be done from a historical perspective, since the continuities and discontinuities with colonial times shed light on the present (Garcés-Mascareñas 2008a). The following sections analyse the formulation, implementation and effect of entry policies and conditions of stay (sections 3.4 and 3.5), regularisation programmes (section 3.6) and deportation campaigns (section 3.7) from the I980s onwards. These four sections represent the core of my research and comparative analysis. The final section in this chapter (section 3.7) sketches some preliminary answers to the main research questions of this study.

\subsection{Exporting goods, importing labour}

\subsubsection{Colonial times}

In the early nineteenth century, before the British gained direct or indirect control of the Malay States, family functioned as the basic unit of a subsistence economy based on rice production, horticulture and fishing. In the late nineteenth and early twentieth centuries, however, British rule 
introduced monocropping in the form of rubber plantations, along with tin mining, the so-called 'twin pillars' of the colonial economy, which served the growing demands of US and British commercial and industrial interests. Consequently within the next few decades, Malaya became a producer and exporter of primary products and an importer of manufactured goods (Kaur I999: 8; Chin I998: 34). As John Stuart Mill (I909: 57) observed, referring to British colonies in general, Malaya became a centre of production within the colonial empire: 'Our West India colonies, for example, cannot be regarded as countries, with a productive capital of their own. [... They] are the place where England finds it convenient to carry on the production of sugar, coffee, and a few other tropical commodities. All the capital employed is English capital; almost all the industry is carried on for English uses; [...] The trade with the [... colonies] is therefore hardly to be considered as external trade, but more resembles the traffic between town and country [...].'

By the I89os, however, the British government concluded that the reason the Malay States had not attracted more British capital was the absence of cheap labour (Parmer i960: I8). The colonial government explained its inability to attract local Malays by referring to their laziness (Emerson 1964: 18) or by arguing that their value system discouraged pursuit of individual gain (Silcock I965: I83). Most likely, the Malays were economically self-sufficient in the communal (village) settings and there was hence no need for them to work under the strenuous conditions and strict disciplinary regulations of wage employment in mines and plantations (Ramachandran I994: 42). Unable to attract local Malays to work in the colonial economy, the British turned to migrant labour from China and India. In fact, as early as the eighteenth century, local rulers had encouraged the immigration of Chinese to overcome labour shortages in their estates. Later on, the Chinese would prove to be pioneers tin and gold mining and the cultivation of several commercial crops, which were worked by newly recruited Chinese migrants. Chinese dominance in mines is illustrated by the fact that in I9II Chinese workers represented 96.2 per cent of the total mining labour force (Kaur I999: 8-9).

In order to neutralise the threat posed by an over-concentration of Chinese workers in the early tin mines, in the late nineteenth and early twentieth centuries, the colonial administration consciously assisted East Indian (Tamil) immigration into the rapidly expanding rubber plantation sector (Halim I986: 26I). This led to a clear predominance of Indian labour in plantations. Indians also worked on the construction of roads, railways and in the public utilities sector. As a result, in I937 there were 306,360 Indian workers (compared with I78,50I Chinese workers) employed in plantations, mines, factories and government departments (Parmer I960: 274). As for the total population of Malaya, by I940, Chinese comprised 42.8 per cent and Indians, I3.6 per cent (see Table 3.I). 
The proportion of women in the total migration flow has been estimated at less than 20 per cent (Sandhu i969: 82).

Table 3.1 Population of Malaya in total numbers and percentages, 1911-1940

\begin{tabular}{lllll}
\hline Origin & 1911 & 1921 & 1931 & 1940 \\
\hline Malays & $1,416,796$ & $1,651,051$ & $1,962,021$ & $2,286,459$ \\
and other & $(52.1)$ & $(48.8)$ & $(44.4)$ & $(41.5)$ \\
Chinese & 915,883 & $1,174,777$ & $1,709,392$ & $2,358,335$ \\
& $(34.2)$ & $(35.2)$ & $(39.2)$ & $(42.8)$ \\
Indians & 267,159 & 471,666 & 624,009 & 748,829 \\
& $(10.0)$ & $(14.2)$ & $(14.3)$ & $(13.6)$ \\
Others & 72,916 & 60,560 & 89,924 & 112,471 \\
& $(3.7)$ & $(1.8)$ & $(2.1)$ & $(2.1)$ \\
\hline Total & $2,672,754$ & $3,358,054$ & $4,385,346$ & $5,504,094$
\end{tabular}

Source: Sandhu (1969: 275)

\subsubsection{Post-colonial times}

After independence in I957, the Malaysian economy remained based on primary commodity exports under control of foreign corporations. In terms of migrant presence, the main difference with the past was that those migrants who were long established in Malaysia yet still seen as foreigners became recognised citizens of the new nation-state and thus definitively settled in the country. At the same time, in the mid-I96os, the switch from rubber plantations to oil palm and cocoa (which were less labour-intensive) reduced labour requirements in this sector. By the late I96os, these changes had brought about a temporary labour surplus, thereby generating migration flows from old to new plantations and to urban areas (Navamukundan I988: 2I7). However, this outflow from rural areas was only a short-lived phenomenon. The ambitious land development schemes embarked on by the Federal Land Development Authority (FELDA) in 1956 to provide landless peasants with new land cleared from the jungle soon created new labour shortages. Two reasons have been adduced to explain how these land development schemes produced labour shortages.

First of all, such schemes led the rural population to remain in their own holdings, thus denying their labour to the plantation sector. People simply preferred to become landowning farmers rather than agricultural workers (Celliah I988: 212; Amin 1988: 199). The magnitude of such development schemes may be seen in the fact that, from I957 to I987, I.2I million hectares of jungle were redeveloped into plantation-type agriculture (Wong \& Anwar 2003: I73). Second, jungle clearing, planting, maintenance work and the construction of settler homes within these land 
development schemes could not be done exclusively by settlers and the tasks were therefore soon given to contractors. As Wong and Anwar (ibid.: I75) observe, it was partly in the context of these schemes that 'the momentous shift from a permanent, settled and captive labour force in the plantation economy (which had been characteristic of an earlier immigrant labour force) to the use of casual contract labour occurred'. While at the beginning, this labour came from the Chinese New Villages and the Malay kampungs (traditional villages), in the mid-I97os labour contractors began to recruit migrant workers (Kassim I994b: 98). By I98I, it is estimated there were about 130,000 Indonesian estate workers in Peninsular Malaysia, which at the time represented about half the total labour force in the sector (Mehmet I988).

\subsubsection{Developmental period}

In the early I970s, the economic inequalities between Malays and Chine$\mathrm{se}^{\mathrm{I}}$ and the consequently exacerbating conflict within and between the two groups led the Malaysian government to implement the New Economic Policy (NEP) (I97I-I990). This development programme was designed to eliminate poverty and to restructure society by dismantling the identification of ethnicity with economic function and geographic space (Chin 2000: I042). The NEP led to unprecedented economic growth, characterised by the shift from an economy based on primary commodity exports to one based on the export of manufactured goods. For instance, while the figures for agriculture and other raw materials dropped from 50 per cent in I970 to II.3 per cent of the total national exports in I990, manufactured goods increased from 6.5 per cent to 54.2 per cent in the same period (Chin I998: 57). This economic shift was facilitated by the transnationalisation of capital and the relocation of production plants from Western to developing countries (Froebel, Kreye \& Heinrichs I980 in Chin 1997), together with the rise of commodity and oil prices (Chin 2000: 1043).

While the NEP promoted economic growth, it also had contradictory effects on the country's labour. On the one hand, the emphasis on urbanisation and industrialisation promoted Malays to a better position within the labour market. For instance, while Malays respectively represented 30.8 per cent and 37.9 per cent of the total labour force in the secondary and tertiary sectors in 1970 , these percentages respectively increased to 48.0 and 51.0 per cent after the NEP (Chin I998: ${ }_{56}^{6}$ ). On the other hand, in contrast with South Korea and Taiwan, economic growth depended on foreign investment that was attracted by emphasising low labour costs (Jomo 2003: 203). Urbanisation and employment policies sought to - and indeed did improve - the socio-economic position of Malaysian citizens regardless of their ethnicity, but economic growth continued to depend on a continuous supply of cheap labour. In this context, the employment 
of legal and illegal migrant workers from neighbouring countries was quickly perceived as being necessary for economic growth and prosperity.

As local labour entered the emerging manufacturing and service sectors, labour shortages in agriculture became even more severe. A survey by the United Planting Association of Malaysia (UPAM) found that in I985 its member estates lost an average of 2 I.8 per cent of their workforce and that about 24,000 additional workers would be needed between I988 and I992 (Amin I988: 200-206). While employers have always attributed these labour shortages to locals being 'too choosy', the trade unions have always argued that these labour shortages resulted from low wages and poor labour conditions. If we analyse the situation in plantations, we soon realise that wages and working conditions had stagnated or declined. For example, though output per worker in the rubber plantation sector increased 2.25 times between I960 and I98I, real wages of rubber tappers declined from $3.40 \mathrm{RM}$ to $3.37 \mathrm{RM}$ in the same period. What is more significant is that wage differentials between rubber tappers and factory workers widened from I.90 to 2.92 between I967 and I98I (Mehmet I988: 22-24 in Pillai I992: 8). In this regard, together with Pillai (I992: $8)$, we could indeed conclude that labour shortages in plantations resulted from poor wages and work conditions.

The construction boom of the late I970s and early I980s, with an average annual growth rate of 8 per cent, also gave rise to a huge labour shortage in this sector. Again, rather than raising wages in response, employers resorted to using immigrant workers mainly from Indonesia. Migrants who went into construction comprised those who moved from the plantation sector as well as newcomers (Pillai I999: 2). By I984, the Ministry of Human Resources (I987-I988) estimated that there were over 500,000 migrant workers, almost all of whom were in plantations and construction. Government-sponsored projects like the airport, the Petronas Twin Towers and the building of new cities like Putrajaya and Cyberjaya in the I990s - all symbols of the much-vaunted 'progress and wealth' of the country - led to exceptional growth in the sector (with an average annual growth rate of 15 per cent) and, once again, the hiring of migrant workers was the main response. The Economic Report of 2003 and 2004 estimated the construction sector as comprising 794,600 workers, 70 per cent of whom $(556,200$ persons $)$ were believed to be immigrants (in Narayanan \& Lay 2005: 37).

By the late I980s, the sustained economic growth also drew Malaysian women into the workforce. This increased female participation in the labour force, together with the expansion of the middle class, led to an immediately heightened demand for foreign domestic workers. While in the I970s there were a few hundred Filipino and Indonesian female domestic workers, by 1994 there were approximately 70,000 and, by 2006, there were 319,383 (New Straits Times I7 March 2006). Their presence has 
been fundamental for economic growth since, first, it permitted and sustained the participation of Malaysian women in the more productive sectors of the economy and, second, it delayed political pressure on the state elite to provide public child care centres or to encourage Malaysian employers to arrange privately owned child care (Chin I998: I09; Chin I997: 369). As Chin (I998: I6) observes, the importation of female domestic labour has been part and parcel of the Malaysian developing plan: 'Today, the service and servitude of foreign female domestic workers result from, and contribute to, the modernity project of nurturing the continued growth of the Malaysian middle class.'

\subsubsection{From the 1990s onwards}

After I990, as economic growth continued, with rates averaging 8 per cent from I987 to I996, the demand for migrant labour became generalised, with shortages reported for the first time in the manufacturing and, later, in the service sector. This led migrant workers' shift from a concentration in agriculture, construction and domestic service to being more or less equally represented in the four major sectors by the late I990s: manufacturing (3I per cent), construction (20 per cent), plantations (25.9 per cent) and service (20.4 per cent, of which 9.3 per cent were in domestic service). The opening up of jobs for migrants in the manufacturing and service sectors gave rise to two new developments. First was longdistance migration with, for instance, Bangladeshi migrants (who represented 27.5 per cent of all migrants in 1999) entering the manufacturing and service sectors (see Rudnick 2009). Second was the feminisation of immigration in Malaysia through the presence of Indonesian and Filipino female migrants not only in domestic employment, but also in the service and manufacturing sectors (Pillai I999: 3). In I994 Kassim (I994a: 5) estimated that female migrant workers represented 29 per cent of the total number of migrant workers in the country. ${ }^{2}$

Despite state attempts to reduce the migrant worker population and the consequent increasing emphasis on high-tech and less labour-intensive industries, there has been an unabated increase in the inflow of migrant workers since the I990s (see Table 3.2). In I995, there were about I.2 million migrant workers $(500,000$ to 700,000 of whom were estimated to be illegal) and, in 2000 , about 2 million (estimated to comprise I.2 million legal and about 800,000 illegal) (Wong \& Anwar 2003: I72; Jones 2000: 54). In 2005 and 2008, the numbers of legal migrant workers rose to I.8 million and 2.I million, respectively (Kassim 2008b), plus an estimated 500,000 to I, 000,000 illegal migrant workers (Syed Shahir 2006). In economic sectors, most legal migrants worked in manufacturing, plantations, construction, domestic service, service and agriculture (see Table 3.2). If one included illegal migrants, the proportion of migrant 
Table 3.2 Legal migrant workers in Malaysia by economic sector (in thousands)

\begin{tabular}{ccccccc}
\hline Year & Agriculture & Manufacturing & Mining & Construction & Service & Total \\
\hline 1991 & 126.5 & 38.9 & 1.9 & 42.1 & 86.2 & 295.6 \\
1992 & 137.2 & 54.1 & 2.3 & 59.1 & 96.5 & 349.2 \\
1993 & 176.1 & 103.9 & 2.1 & 51.4 & 107.5 & 441.0 \\
1994 & 179.5 & 109.8 & 2.0 & 58.1 & 110.9 & 460.3 \\
1995 & 173.0 & 115.7 & 1.8 & 64.8 & 124.0 & 479.3 \\
1996 & 271.6 & 264.8 & 3.5 & 131.2 & 229.0 & 900.1 \\
1997 & 265.2 & 283.0 & 6.1 & 150.1 & 240.9 & 945.3 \\
1998 & 317.6 & 250.1 & 2.6 & 151.4 & 278.0 & 999.7 \\
1999 & 363.6 & 250.6 & 6.0 & 131.1 & 301.9 & 1053.7 \\
2000 & 415.4 & 262.5 & 2.9 & 163.5 & 326.7 & 1171.0 \\
2001 & 281.4 & 213.0 & 2.1 & 99.0 & 265.6 & 861.1 \\
$2005^{*}$ & 412.0 & 614.0 & NA & 101.0 & 160.0 & 1,800 \\
\hline
\end{tabular}

Source: Ministry of Human Resources (2004: 36).

* Data obtained from the New Straits Times 19 July 2006

workers would be far higher in construction but with a significant presence also in plantations, domestic service and manufacturing (Wong \& Anwar 2003: I74-I75). As for nationality, most legal migrants came from Indonesia, Nepal, India, Myanmar, Vietnam, Bangladesh, the Philippines and Pakistan (for developments over the years, see Table 3.3).

Table 3.3 Distribution of migrant workers by country of origin (\%)

\begin{tabular}{lccccccc}
\hline Country & 1997 & 1998 & 1999 & 2000 & 2001 & 2002 & 2006* \\
\hline Indonesia & 50.4 & 53.3 & 65.7 & 69.4 & 68.4 & 64.7 & 67.5 \\
Bangladesh & 39.4 & 37.1 & 27.0 & 24.6 & 17.1 & 9.7 & 3.2 \\
India & 3.1 & 3.6 & 3.2 & 3.0 & 4.0 & 4.6 & 7.7 \\
Myanmar & 2.2 & 1.3 & 0.9 & 0.5 & 1.0 & 3.3 & 5.1 \\
Thailand & 0.5 & 0.7 & 0.5 & 0.4 & 0.4 & 2.4 & 0.4 \\
Philippines & 2.7 & 2.7 & 1.8 & 1.2 & 1.0 & 0.8 & 1.2 \\
Pakistan & 1.7 & 1.0 & 0.6 & 0.5 & 0.4 & 0.2 & 0.8 \\
Nepal & 0.0 & 0.1 & 0.1 & 0.1 & 7.3 & 9.7 & 11.1 \\
Others & 0.0 & 0.2 & 0.2 & 0.3 & 0.4 & 4.6 & 5.5 \\
\hline
\end{tabular}

Source: Ministry of Finance (2005)

*Data obtained from the New Straits Times 19 July 2006 
In the regularisation programme of 1998 , most regularised migrants thus former illegal migrants - came from Indonesia (88.I per cent), Thailand ( 6 per cent), Bangladesh ( 5 per cent), Myanmar ( 2.5 per cent), India (I.9 per cent) and Pakistan (o.8 per cent) (ibid.).

In general terms, we can conclude that economic growth in Malaysia, associated with an export-oriented economy since colonial times, has always been achieved by relying on immigrant labour. The exportation of goods and the import of migrant labour have been, and still are, thus closely entwined concepts in Malaysia. While in colonial times the exportation of tin and rubber within the increasingly connected world economy was made possible by the importation of Chinese and Indian labour, in the last decades, the country's exportation of manufactured goods within an increasingly globalised economy has been based on the importation of migrant labour from Indonesia, Bangladesh, the Philippines and other Asian countries. At the same time, while sustaining growth, immigration has contributed to the consolidation of a dual labour market that, in turn, has intensified Malaysian reliance on migrant labour. In colonial times, labour in the foreign-owned, export-oriented tin and rubber sectors was mainly performed by immigrants. In recent decades, migrant labour has not remained limited to export-oriented sectors, but has been present in those jobs perceived by local workers as dirty, degrading and dangerous. This explains why, despite the recession and growing unemployment of I985, I997 and 2002, employers' complaints of labour shortages persisted.

\subsection{Towards a guestworker policy}

\subsubsection{Colonial times}

By the time British metropolitan interests had begun to seek large supplies of cheap labour, Chinese workers had become a relatively freer labour force. They were perceived as 'very closely knit, self-governing communities, homogeneous, united in aim, if often mutually antagonistic, and, by virtue of their secret society or guild organization, with strong internal discipline and stability to present a united front to outsiders' (Jackson I96I: 57). In short, the early colonial, metropolitan-protected plantation industry found Chinese labour too organised and expensive. The colonial economy, tied to the ups and downs of the capitalist world trade cycle, required an alternative (cheap, stable and continuing) supply of foreign labour. The British colonial authorities therefore turned their attention to Indian workers.

Unlike Chinese workers, South Indians were perceived as a 'peaceable and easily governed race'. There was general consensus that South Indian 
Tamils were reliable and ideal for plantation work as they were supposed to have all the 'required qualities' such as humility, loyalty, docility, submissiveness and malleability (Summugam a/l Rengasamy 2006: 265). Most came from landless, untouchable and vassal groups, for example, the paraiyan, chakiliyan and pallan castes, and were therefore well accustomed to being in thraldom to the upper castes and subject to the paternalism of the British Raj (Selvaratnam I980: 9). Poverty in South India itself also played an important role. The agrarian crisis during the Madras Presidency and the further pauperisation of peasants due to British imperial policy spurred on a readiness to migrate (Stenson I980 in Ramachandran 1994: 53). Apart from being perceived as a cheap, docile labour force, Indian labour was also meant to counterbalance the growing Chinese population in Malaya. This is reflected in a statement by Sir Fredrick Weld, governor of the Straits Settlements, who noted in I887: 'I am anxious for political reasons that the great preponderance of the Chinese over any other races in these settlements, and to a less marked degree in some of the Native States under our administration, should be counterbalanced as much as possible by the influx of Indian and other nationalities' (in Parmer I960: 19).

Unlike Chinese immigration, Indian immigration was planned and supervised by the colonial authorities to suit British employers and themselves. The fact that India was under the rule of the same colonial empire paved the way for the Malayan government's importing and exporting of Indian labour according to its requirements in Malaya. When labour was in demand, the Malayan government issued licenses to recruiters so that 'fresh workers' could be brought into the country. When the rubber market was depressed, the government shared expenses with the Indian Immigration Fund - based partly on a levy imposed on all planters who used Indian labour (on a per capita basis) - for the repatriation of Indian workers back to their homes (Beeman I985: 264; Ramachandran I994: I06). By regulating migration, employers were able to exploit the productive capacities of their estates. They were immune from the danger of wage increases caused by labour shortage. By using repatriation as an unemployment policy, the state was able to avoid the costs of unemployment such as public works programmes and welfare facilities. Although the tactic was opposed by employers who feared future labour shortages, the colonial authorities preferred repatriation to maintaining the unemployed (Beeman 1985: 264).

It is important to make clear that Indian migrants were only expected to return home in cases of unemployment or health problems. The rest could stay in colonial Malaya as long as they were required. In fact, to ensure a stable supply of low-wage labour and the stability of the Indian migrant community, the colonial government encouraged entire Indian families to migrate. This policy manifested in an increase of Indian 
women living in Malaya (from 26.I per cent in I9II to 39.9 per cent in I93I), and resulted in the settlement of many Indian migrants. However, they could only settle as 'eternal foreigners'. As perceived 'birds of passage', Indian and Chinese migrants were not granted nationality status or full rights as this would have been at odds with the stated policy of 'ruling' Malaya for the Malays or, in other words, of considering only Malays as 'sons of the soil' (Kaur 2004: 4; Selvaratnam I980: II). As stated in the Malaya Tribune (in Selvaratnam I980: II): ‘[A]n Indian or a Chinese after settling down in Malaya under British colonization and British protection may become a British subject or British protected subject according to the English law, but it is not right to identify such a man as a subject of the Malay rulers, unless he adopts the Malay religion, according to the custom' (quoted in Selvaratnam i980: II).

\subsubsection{Post-colonial times}

By independence in I957, of the total population the Malays represented 49.8 per cent, the Chinese, 37.2 per cent and the Indians, II.I per cent (Chin 2002: 44). Under colonial rule, these ethnic categories had acquired real and/or imagined attributes such as language, customs and religion. While the Malays had previously been divided into sub-ethnic categories such as Javanese, Bugis and Minangkabau, the Indians, into social castes and the Chinese, into dialect groups, the official idiom of the colonial government, together with a series of policies and legislation, had now merged all these differences into three ethnic categories (Shamsul i998: I36). As already noted, 'Melayu' became the term exclusively used to refer to all those who 'speak the Malay language, profess Islam and habitually follow Malay customs' (Andaya \& Andaya I982: 302). Moreover, Malay, Chinese and Indian identities were constructed and segregated according to employment and geographic space. While Malays had been encouraged to remain predominantly as peasants in rural areas, the Indians had been channelled to plantations and infrastructural projects and the Chinese had managed tin mines and small businesses in emerging urban areas (Chin 2000: 1053).

The new Malaysian state was thus constructed on the basis of these three groups. The tricky question of acknowledging non-Malay presence and demands without negatively affecting Malay claims to political and cultural dominance was resolved with the so-called Bargain of 57 according to which Chinese and Indians were granted citizenship and, in return, these two minority groups accepted Malay as the national language, Islam as the national religion and an electoral system that ensured Malay political dominance by favouring the rural districts in elections (Spaan, Van Naerssen \& Kohl 2002: I63). This led to the new government being organised on an ethnically 'consociational' basis, ${ }^{3}$ in which each political 
party represented one racially based communal segment of the society. Ever since, the Malaysian government has been ruled by an alliance of the three major ethnic parties: United Malay National Organisation (UMNO), Malayan Chinese Association (MCA) and Malayan Indian Congress (MIC).

One of the first pieces of legislation passed by the new nation-state was the Immigration Act (I959) to regulate the entry and movement of foreigners into Malaysian territory. The new legislation was designed to restrict entry of family members of local residents and, in so doing, claimed to be safeguarding the employment and livelihood of established residents as well as bringing about further assimilation in the country (Kaur 2004: I5). The Immigration Act was followed by an Employment Restriction Act (I968) that made foreigners' access to the labour market contingent on possession of a work permit. As Wong has observed, the institution of the new nation-state was thus made legally coterminous with that of a closed labour market. While citizenship conferred the right of residence within the bounds of a nationally defined territory and gave right of entry to its labour market, foreigners were exempted from both (Wong 2002: 4). However, there was an additional important nuance. Although the legislation referred generally to citizenship, in practice, it had a notable ethnic component.

On the one hand, the Immigration Act and the Employment Restriction Act affected primarily Chinese and Indians. Those who had not taken up citizenship - some of whom were resident in the country for all or most their lives - were repatriated or compelled to leave otherwise. Moreover, further tightening of migration rules made it even more difficult for Chinese and Indian migrants to enter the country and join their family members (Kaur 2004: I5). On the other hand, immigrants from the neighbouring islands of the archipelago, such as Sumatra and Java, did not fall under the legal category of 'aliens' and hence did enjoy free entry to Malaysia and its labour market (Wong 2002: 5). In this regard, we can conclude that the application of the first migration policies in Malaysia was based on two (sometimes contradictory) principles: citizenship and ethnicity. In other words, the border was drawn not only between citizens and non-citizens, but also (or at the same time) between Malays (including Indonesians) and non-Malays.

This double border continued to operate until the late i980s. Until then, the presence of thousands of Indonesians working illegally in rubber and oil palm plantations and on construction sites did not attract much public attention. They were perceived as temporary (even seasonal) workers, similar to Malays. The border became even more blurred when, as Pillai (2005: I69-I70) has shown, most illegal Indonesian migrants received their permanent residence status within two or three years of entry and some even within months. Some of them obtained these docu- 
ments legally, others illegally or with the connivance of state officials. The main result of this (selective) border permeability was that most Indonesians who arrived before the late I980 could settle in Malaysia. This had a spin-off effect: their offspring could become citizens of Malaysia and hence qualified as Malays under the affirmative action programmes designed to bring the Malay community onto socio-economic parity with the Chinese and Indian communities. ${ }^{4}$

\subsubsection{From the late 1980s onwards}

As Indonesian migrants started to move to urban areas, particularly to those economic sectors reserved for local workers, their presence started to be seen as challenging the NEP employment policy. They were seen as competing with local workers in the labour market and notably challenging the preordained redistribution of wealth and employment among the different ethnic groups. For instance, in the mid-I980s until the end of the decade, Malay petty traders in the major cities staged vociferous protests against the illegal Indonesian workers as they feared being economically displaced. Moreover, non-Malay communities accused the state of turning a blind eye to the inflow of Indonesian migrants and hence surreptitiously increasing the Malay share in the overall population. Although Dorall (I989) finds that ethnic politics correlate with migration politics, this view should be nuanced since the migrant workers' main importers (including recruiting agencies) and employers have been nonMalays, particularly the Chinese (Kassim I997: 23).

My main argument is that the reaction to illegal (mainly Indonesian) migration in the late I980 should be understood not only in ethnic terms. It must also - and above all - be seen from a social-class perspective: it was the urban lower-class Chinese, mainly represented by the Democratic Action Party (DAP), who, like their Malay correlates, felt threatened by migrants' presence. In this regard, although the association of ethnicity with economic function still characterises union membership to a certain degree, 5 it is not surprising that, since the mid-I980s, Malaysian trade unions have opposed the presence of migrant workers. As argued repeatedly by the Malaysian Trade Union Congress (which claims to be the only mass multiracial organisation in Malaysia), trade unions have seen migrant workers as obstacles to their efforts to fight for better wages and work conditions. When employers requested migrant workers on the grounds of alleged labour shortages, trade unions always replied that there was a shortage of cheap labour but not of labour, per se.

A need to protect the national labour market finally displaced ethnicity as a key component of (the implementation of) migration policies, thereby setting up citizenship as the undisputed border, if not barrier, to free entry on the labour market. This gradual closure and delimitation of 
Malaysian borders gave rise to a twofold phenomenon: gradual exclusion of illegal migrants and development of a temporary labour migrant system to 'manage' the entry, stay and repatriation of a foreign labour force that was in demand yet unwanted. In fact, as I shall show in the next sections, these are interrelated trends: while the exclusion of illegal migrants finally led the government to organise labour migration flows to Malaysia, the rigidities of the migrant labour system created new illegal immigrants as well as other kinds of illegality.

As an issue of national significance, illegal migration was first raised in Parliament in 1976 by members of the opposition DAP. This was followed by introduction of the term 'pendatang haram' ('illegal migrant') or, shortly thereafter, the more politically correct 'pendatang tanpa izin' ('migrant without permission') into the Malaysian public vocabulary (Wong \& Anwar 2003: I69). While at first the terms referred to the Vietnamese refugees ('boat people') arriving in Malaysia in the late I970s, in less than a decade it would become almost synonymous with illegal Indonesian migrant. This shift came hand in hand with new connotations that associated illegality with contagious diseases, begging, prostitution, 'deviant' religious teaching, urban squatters, criminality and subversive political activities. These negative images have contributed to what Fernandez (1997) has called 'migrant bashing', literally and figuratively, in society. As noted by Chin (2002: 33), the question is not whether some migrant workers engage in unlawful activities, but rather that such negative representations became 'a key management strategy of migrant workers' public identity as outsiders or "illegals" whose movement in society must be surveilled, if not overtly contained'.

This process has barely been challenged by Malaysian NGOs. In fact, only a few organisations, such as Tenaganita and Suaram, work for the defence of (legal and illegal) migrant workers' rights in Malaysia. ${ }^{6}$ Multiple reasons have been given to explain the lack of response. First, human rights arguments often end up disempowering activists, who risk being branded pawns of the West by a government that frequently professes Asian values7 (such as loyalty, hard work and docility) as opposed to Western-derived human rights norms (Gurowitz 2000: 864). Second, many activists and NGOs, frequently 'leftist' in orientation and potential allies of immigrants, are non-Malay. This might explain their limited role in the defence of (mainly Indonesian) migrant workers (ibid.: 875). Finally, and probably above all, as illustrated by the 1996 arrest of Irene Fernandez, head of Tenaganita, for publishing a report that denounced abuses in detention camps, ${ }^{8}$ laws such as the Internal Security Act (a preventive detention law, in force since 1960) and the Printing Presses and Publication Act (a law on dissemination of information, in force since I984) have been used to suppress open debate and check opposition from civil society. 
Parallel to its policy of excluding illegal migrants, in I99I the Malaysian state introduced a set of measures to regulate the recruitment, employment and return of migrant workers. In general, these measures sought to determine the age, gender, nationality, employment sector, location and duration of residence and employment of foreign workers in Malaysia. The idea behind these specifications was to adapt labour migration to the requirements of a set of preconceived factors such as the level of economic activity and rate of unemployment, sectorial labour market imbalances, the numbers of undocumented workers, national security, diplomatic relations and the pressure of particular interest groups (Kanapathy 2004: 382). Most Malaysian scholars have described migration policies as being inconsistent, changing and ad hoc (Pillai 1999, 2000, 2005; Kassim I993a, I994b, I995, I997, I998; Chin 2002; Kanapathy 2004). However, as I shall argue in the next section, what has been defined as ad hoc could be understood as part of a guestworker policy aiming to maintain high levels of labour migration while at the same time working towards the closure of national borders.

\subsection{Letting them in...}

\subsubsection{Defining numbers}

By regulating migration flows, the state aims to define the number of migrants allowed to enter and work in the country. In the Malaysian case, this has been determined by two contradictory demands. On the one hand, migrant workers were perceived as being needed to ease labour shortages in critical sectors such as plantations, construction, manufacturing and service. Since economic growth has depended on foreign investments attracted to low labour costs, the availability of cheap foreign labour was seen as essential. On the other hand, migrant workers were also perceived as a threat to what was deemed the proper redistribution of wealth and employment among the different ethnic groups (Malay, Chinese and Indian). As we have seen, trade unions systematically opposed the entry of migrant workers. This contradiction of demands was solved by letting in only those migrant workers perceived as needed for economic growth and only in sectors or occupations where nationals did not work. While this policy is common to most nation-states, what remains to be considered is how the Malaysian state defined its 'necessity' for migrant workers. That is, how many migrants were perceived to be 'needed'.

Although this process is not defined in any published document, it is common knowledge that employers are required to advertise their vacancies in local newspapers and through the Electronic Human Exchange System of the Human Resources Department. If no national workers are 
available, employers should submit an application for the recruitment of migrant workers to the Ministry of Home Affairs. These applications, according to an Immigration Department official, are sent to a specific technical committee that defines whether the application is 'genuine' or not (interview 6 October 2006, Kuala Lumpur). This means considering whether there are national workers available, whether the request complies with the quotas established per economic sector (e.g. in 2006 this quota was one migrant worker for every three local workers in manufacturing, but three for every one in construction) and whether applicants are direct employers or recruitment agencies (if the latter, the application is rejected). Other factors that may be taken into account are the volume and duration of the project, whether the employer is a subcontractor or the main contractor and the positions for which migrant workers are required. As the representative of the Construction Industry Development Board Malaysia (CIDB) observed: 'For specific tasks - the most difficult, dangerous and dirty tasks - employers can bring as many foreign workers as they want. I mean, for these tasks, there is no ratio between locals and foreigners' (interview io October 2006, Kuala Lumpur).

Trade unions complain that this process should be more transparent. As the representative of the Malaysian Trade Union Congress said: 'The government should establish which sectors need foreign workers and how many' (interview 3I October 2006, Kuala Lumpur). Similarly, the representative of the Malaysian Employers Federation denounced this as 'a cumbersome procedure. It depends a lot whether you know somebody there. If you are close to officials from the Immigration Department, you get it. If not, you can keep waiting for months and months, just going around from one person to another' (interview I3 September 2006, Kuala Lumpur). In fact, apart from the requirements mentioned above, applications can be reviewed case by case. This means that having good contacts within the Immigration Department can facilitate, if not speed up, the whole recruitment process. Contacts can be direct between employers and government officials or via the so-called recruitment agencies, which often mediate between employers and the Malaysian government. Despite such limitations in the procedures, between 400,000 and 700,000 migrant workers enter Malaysia every year. These numbers would seem to suggest that the 'necessity' for migrant workers is defined in broad terms. It seems that, as the Malaysian Agricultural Producers' Association (MAPA) representative remarked: 'For employers it's not a problem to get foreign workers' (interview i4 September 2006, Kuala Lumpur).

Apart from case-by-case evaluation of foreign labour demands, the Ministry of Home Affairs has regularly enforced a series of bans (in I993-I994, I997, 200I, 2002, 2005) on different categories of migrant workers. In 1997 this was justified by Prime Minister Mahathir, who stated: 'The country cannot go on depending on foreign workers. We have 
20 million people and I.7 million foreign workers. If we allow this to go on we would risk losing control of our country' (Bulletin Imigresen I997 in Wong \& Anwar 2003). While the Prime Minister invoked security reasons, on other occasions a freeze on the employment of migrant workers was justified by the need to protect national workers, to prevent social problems or to reduce migrant remittances. Despite all these arguments, employers' complaints about the persistence of labour shortages and their negative consequences on economic growth (affecting national and multinational companies as well as government-constructed megaprojects) led on each occasion to an immediate lifting of the ban. For instance, I997's prohibition on fresh labour recruitment meant that out of requests by employers for 225,275 work permits in I998, only 2,876 were granted (Wong \& Anwar 2003: I8I). However, as it was revealed that RM 2 billion had been lost in I997-I998 because of labour shortages, by mid-I998 the government had announced that permission would be given to foreign exchange sectors (such as plantations) to employ 'fresh' migrant workers as well as to redeploy migrant workers from other economic sectors. In early 1999 the freeze on the importation of foreign labour was lifted in the construction, manufacturing and service sectors.

These constant shifts - in terms of allowing, restricting and banning migrant entry - have been interpreted by most Malaysian scholars as outstanding examples of the ad hoc, stop-go character of Malaysian migration policies. From a historical perspective, it becomes clear that these shifts resulted from the dilemmas and contradictions underlying the state's decisions in the field of migration. As the Human Resources Ministry once said: 'The government was seeking to strike a balance between ensuring there is no labour shortage and employers not taking advantage of the situation at the expense of local workers' (New Straits Times, 28 November I99I). This balance, however, was sometimes difficult to attain. Despite the recurrent introduction of temporary bans on the employment of migrant workers, the Malaysian state did always reopen the 'gates' in the end. We can thus conclude that employers' demands were systematically attended to. This was the case not only because employers succeeded in imposing their interests, but also because economic growth and development was one of the main concerns of the Malaysian state itself.

\subsubsection{Regulating migrants' origins}

State regulation of migration flows has sought to determine not only the number of migrant workers allowed to enter in the country, but also their origins. As in the colonial past, the state aimed to create a docile and malleable labour force by diversifying migrants' origins. This has meant, in particular, countering the power of a specific sending state or the dominance of a specific national group within Malaysian national territo- 
ry. The best illustration of the former is the case of the Philippines. When in 1997 the Filipino state asked for an increase in the wages of its domestic workers in Malaysia (from RM500 to RM7509), the Malaysian state reacted by banning their employment. An illustration of the latter is the case of Indonesian migrants. In 2002, following several riots in work places and detention camps, the government announced its 'Hire Indonesians last' policy, that is, effectively putting a stop to the recruitment of Indonesian migrants. The official argument, as expressed by Prime Minister Mahathir, was that it was time for Indonesian workers in Malaysia to be 'replaced' by other nationalities. As in the past when Indian labour was promoted by colonial authorities to counterbalance the Chinese presence in Malaysia, labour migration from countries such as Vietnam and Myanmar began being encouraged after 2000 so as to reduce Malaysian reliance on Indonesian labour.

But to what extent could the Malaysian state determine the origin of the Malaysian migrant labour force? In fact, here, too, the markets countered any policy that did not fit their demands. For instance, the ban on Filipino domestic workers was followed by an immediate reaction from employers. 'Consumers' of this specific kind of labour - which is to say, families set on having Filipino domestic workers - protested by arguing that they should have the right and the freedom to choose their own domestic workers based on select characteristics. Interestingly, their arguments were exclusively in terms of market demand. As a protesting employer was quoted in a local newspaper: 'Since Indonesian maids are Muslims, it is not proper to ask them to cook certain food. To hire an Indonesian maid would only cause inconvenience to us and the maid. [...] We are comfortable with Filipino maids because they can speak English and are hardworking. [...] If we can afford to pay, why not let us hire them since it is our money? I0 (New Straits Times 8 September 1997). A group of employers similarly protested via open letter to another newspaper: 'Please do not tell us that we can settle for other nationalities. We have our preference. Isn't Malaysia a democratic society?' (Business Times II September I998). Once again, following such protests, the ban was immediately lifted.

Partly thanks to employers' demands, the Filipino state succeeded in imposing its own conditions beyond its national borders. This state transnationalism, or transnationalism from above, was in fact the result of the commodification of Filipino domestic workers (see Ezquerra \& Garcés-Mascareñas 2008). Indeed, only by envisaging them as luxury items or consumer goods with added value, or as commonly identified as the 'Mercedez-Benz of domestic workers', could the Filipino state impose higher wages for its domestic workers in Malaysia. In I995, the Indonesian government unsuccessfully tried the same undertaking for its nationals. In this case, employers' protests were substantially different. As one employer argued: 'With RM1000 a month [the wage demanded by the 
Indonesian state], it is better for me to hire two Filipino maids who are better trained and understand English since my current Indonesian maid does not even know what a refrigerator is' (New Straits Times 28 February I995). Independently of 'the market value' of its domestic workers, Indonesia's demands were rejected on the basis of two main arguments. First, Malaysia is the main destination country for Indonesian migrants. In this regard, unlike the Philippines, the argument was that Indonesian domestic workers had no other alternative but to accept their conditions. Second, Indonesian domestic workers are mainly employed by the Malaysian middle class who cannot afford to pay more.

While the Indonesian government could not impose its wage conditions within Malaysian national territory, neither could the Malaysian government impose a ban on the recruitment of Indonesian migrant workers. The 'Hire Indonesians last' policy, which was meant to stop Indonesian labour migration to Malaysia, clashed with the structural significance of Indonesian workers in the Malaysian economy. For instance, with 70 per cent of all construction workers being Indonesians, the halt was followed by a reduction overnight of construction output by some 40 per cent. It was also predicted that the 'disappearance' of Indonesian harvest workers would cause vegetable prices to rise as much as 30 per cent (Liow 2004: 22). In consequence, the policy was quickly recognised as unviable and abruptly rescinded after two weeks. The executive director of the Malaysian Employers Federation (MEF) argued the impossibility of renouncing Indonesian workers in the following terms: 'Based on employers' experience, the Indonesian workers are more suitable to work in this country due to several reasons. Firstly, the Indonesians have no problems in adjusting to the Malaysian culture in terms of language, social, food and religion. Secondly, the working environment in Indonesia is similar to Malaysia and they have the necessary skills required in Malaysia. Language is also an important factor to be considered as the Indonesians have similar mother tongue as Malaysians and thus facilitate communication and training. Thirdly, employers have positive views on the work culture and attitude of Indonesian foreign workers who are willing to work extra hours to increase their productivity' (New Straits Times I4 February 2002).

While in the cases of the Philippines and Indonesia the state regulation of migrants' origins was opposed by employers' demands, in others it could be implemented without much conflict and protest. In 1997, for instance, a freeze on the recruitment of Bangladeshi workers was imposed arguing, first, that Bangladeshi migrants caused social unrest, particularly as a consequence of the alleged popularity of Bangladeshi men among Malaysian women. Second, the Malaysian government justified the halt by referring to the abuses committed by Bangladeshi recruitment agencies. As described by an immigration officer: 'Bangladeshi agencies charged at that time around 10,000 to 15,000 RM per worker. The workers themselves 
had to pay it. This was a lot, and led to exploitation. So in 1996 we said: before recruiting more Bangladeshi workers, solve first your problem at home!' (interview 6 October 2006, Putrajaya). As a result of this halt, the presence of Bangladeshi workers decreased from representing 39.4 per cent of all migrant workers in Malaysia in 1997 to just 3.2 per cent in 2006. While reducing the number of Bangladeshi migrants in Malaysia, this same policy led to rising numbers of workers from new emigration countries such as Myanmar (from 2.2 per cent in I997 to 5.I per cent in 2006), Nepal (from o to II.I per cent in the same timeframe) and Vietnam (from o to 4 per cent in the same timeframe) (see Table 3.3).

\subsubsection{Privatisation of recruitment}

Unlike European guestworker programmes, the recruitment of migrant workers in Malaysia has always been managed by private agencies. Dubbed 'manpower suppliers' and, more recently, 'labour outsourcing companies', these private agencies organise the whole migration process: from small villages in Indonesia, Bangladesh or Nepal to the factory, plantation, construction site or household in Malaysia. Following employers' requests, recruitment agencies in Malaysia contact their counterparts in the country of origin. These counterparts recruit migrants in the villages (often through other agents) and send the required information to the Malaysian agency. Once employers agree on the characteristics of the migrant workers proposed, both the agency in the country of origin and the one in Malaysia initiate the legal procedures to send and receive them. Recruitment agencies in Malaysia organise not only the whole registration process, but also the renewal of the work permit and the annual payment for medical check-ups, insurance and levy.

Employers have often defended the presence of recruitment agencies by stressing their role as coordinators of the recruitment process as well as in the deployment of migrant labour from completed jobs to new ones. From this perspective, recruitment agencies have often been presented as necessary 'managers' or 'guardians' of a migrant labour system that does not work alone or, in other words, that needs a 'middleman' to cope with the distance between labour's supply and demand, to deal with legal procedures and to redistribute migrant labour and return immigrants to their countries of origin after the prescribed period of time. This is how recruitment agencies present themselves as well. The president of the Malaysian Association of Foreign Maid Agencies went still further, stating on several occasions that recruitment agencies are the only entities that can control employers and mediate between them and migrant workers: 'Ifyou come without an agency, who controls the employer? I told the government that foreign workers should always come through an agency. The agency makes sure that employers pay. The agency also makes sure that employers send their 
workers back to their countries of origin after the termination of their contracts' (interview 26 September 2006, Kuala Lumpur).

At the same time, recruitment agencies have often been portrayed as 'unscrupulous people' who overcharge migrant workers and 'cheat' them. The Malaysian newspapers are full of such cases. For instance, migrant workers who have been given false promises in terms of salary and/or work conditions are reported almost every week. There are also cases of migrant workers who are abandoned upon arrival to Malaysia after having paid huge amounts of money to their recruitment agencies. Without proper documentation or a real employer behind a work pass, they immediately become 'illegal' and therefore may be deported to their countries of origin just after arriving. In fact, this is not so unlike abuses committed by Indian recruiters known as kanganies in the late nineteenth century. Then, as now, there was regular denunciation of recruiters' practices of using bribery to encourage workers to migrate, guaranteeing young migrants a good future, exploiting family quarrels to induce people to migrate and giving false information about wages and living conditions in Malaya (Sandhu I969: I0o; Parmer I960: 58; Ramachandran I994: 60-6I). Along these lines, one contractor in 1890 reported the following to a commission of enquiry: 'I can confidently assert that not one single coolie who leaves India knows the real value of the rupee in this country, nor the cost of living here. The recruiters are scoundrels to a man; they not only make gross misrepresentations to the intending emigrants, but even employ force to bring them over' (in Netto I96r: 24).

Employers, trade unions, NGOs and the government itself have coincided in denouncing recruitment agencies, accusing them of charging exorbitant fees and practising a great number of irregularities. On the one hand, employers and government officials have underlined how these irregularities make the whole recruitment process more problematic and inefficient. For instance, companies often complain that agencies are providing them with 'the wrong types of foreign workers and this mismatch costs them time and resources' (Business Times 26 September I992). As a representative of the Malaysian Agricultural Producers' Association stated: 'We don't take workers from the agency here, because we would receive rubbish' (interview I4 September 2006, Kuala Lumpur). Employers and the Malaysian government have also complained that exorbitant fees increase the numbers of cases of absconding. As the Rural Development Minister senator put it in I994: 'IIf the foreign workers are required to make high repayment because of the high costs, the Government fears that they will abscond to seek other jobs' (New Straits Times 7 July I994). On the other hand, NGOs and trade unions have been more concerned with migrant workers' welfare. Their main argument has been that the presence of recruitment agencies, along with their regular and irregular practices, have increased the vulnerability of migrant workers in Malaysia. 
The ongoing tension between the demand for private agents to manage the recruitment and employment of migrant workers versus the rejection of their abusive practices is manifest in the formulation of migration policies. In I992, the Human Resources Ministry amended the Private Employment Agencies Act I98I to make using private agents mandatory in the recruitment of foreign labour. This change arose from the perceived need for a more orderly process. Since these agencies were familiar with the required procedures, it was thought that their involvement would help expedite intake of workers (Business Times 26 September I992). Three years later, however, the recruitment of migrant workers (all but domestic) became the exclusive responsibility of the Home Ministry's Foreign Workers Task Force. This shift was then explained by a need to circumvent this middleman's course and establish a centralised apparatus that would ensure quicker and tidier processing of workers' recruitment (New Sunday Times 20 August I995). Nevertheless, this attempt to centralise recruitment was doomed to fail. Although recruitment agencies were formally proscribed, employers never stopped using their services. As the representative of one recruitment agency declared: 'We have always helped them. But then we were not recognised. We did all the procedures, all the papers, but under their name' (interview 20 September 2006, Kuala Lumpur). In fact, this was known and tolerated by the government.

The Immigration Department repeatedly requested to deal directly with the employers, but did not intervene in what employers did before and after getting the work permit (interview with an officer of the Immigration Department, 6 October 2006, Putrajaya). At the same time, this lack of recognition left recruitment agencies in a kind of legal limbo that made it even more difficult for the government to control them. This is one of the reasons the government decided to re-legalise recruitment agencies in January 2006. From then on, they came to be called 'outsourcing companies' and have been recognised as the legal employers of migrant workers. As 'legal' employers, they are responsible for the recruitment and stay of migrant workers in Malaysia. As recruiters, they supply or 'outsource' their foreign labour to 'real' employers. Again, this does not differ very much from the past. In the late nineteenth and early twentieth centuries, the kangany not only recruited, but also supervised and organised the migrant labour force within the estates. For this service, as presently occurs with outsourcing companies, the kangany was paid 'head money', usually two cents a day for every worker who appeared for work (Parmer ig60: 68).

Employers had been asking for the creation of outsourcing companies since the early 2000s. The Malaysian Employers Federation, the Federation of Malaysian Manufacturers and the Master Builders Association Malaysia conceived outsourcing companies as a way of facilitating the mobility of workers. Since work permits are only given on the basis of a 
two-year contract, employers proposed these companies work not only as recruiters, but also as redistributors of migrant workers (on a temporary basis) within the Malaysian labour market. However, as all employers consistently pointed out, outsourcing companies have not fulfilled this role. In particular, the agencies do very little to advance the mobility of migrant workers since most try to impose on employers at least a one-year contract. The reason, according to outsourcing companies, is to avoid the risk of unemployment. In other words, if migrant workers are not employed as outsourced labour for the whole of their stay, these companies become responsible for their salaries, accommodation and fees, and are thus faced with rapidly increasing costs.

What the outsourcing companies do accomplish is facilitating the recruitment and employment of migrant workers. Freed of the complex tasks of organising the recruitment, applying for work permits and renewals or being responsible for migrant workers' stay in Malaysia, employers only have to pay a fixed sum (in September 2006 it was RM 62 per day and worker) for such services. Moreover, according to trade unions and NGOs, this system of labour outsourcing offers many opportunities for employers to get around legal obligations and escape payment. First of all, it undermines the conditions and wages established in collective agreements since outsourcing companies are not employers working in a particular economic sector and are therefore not bound to their specific obligations. Second, it blurs the legal contours of the employer and his or her responsibility vis-à-vis migrant workers. As a member of the NGO Tenaganita questioned: 'Lots of employers prefer outsourcing because they are not liable. Who is the employer? Some people say that the employer is the one who pays the salary. But sometimes the salary is paid through the outsourcing company. Some people say that the employer is the one who coordinates. It is not clear. The problem then is: who is responsible before the law?' (interview 4 October 2006, Kuala Lumpur).

In terms of migration flows, the privatisation and commercialisation of recruitment, but also employment of migrant workers, in Malaysia has had a twofold effect. First, it has increased the costs of legal migration. A comparison of costs involved is very instructive. While in 2005 recruitment fees via regular agencies rose from $\mathrm{RM}_{2}, 000$ to $\mathrm{RM}_{3}, 000$, transport to Malaysia via the jalur belakang ('back door', which was mostly by boat) rose from RM Ioo to 2,200 (Kejser 2006: IO). Other studies have documented the same. In 2002, for instance, the recruitment fee from Aceh and Lombok (Indonesia) rose to RM I,000 and RM I,200, respectively, as compared with RM 500 and RM 450 for a boat passage to Malaysia (Wong \& Anwar 2003: I98). In 2007, the fee paid to recruiters of Indonesian domestic workers could range between RM I, ००० to RM 2,000 (ISIS 2007). If we add to this other expenses such as the passport, induction courses, medical checks and levies, it is not difficult to understand why 
one of the main reasons given by migrants (particularly from Indonesia) for not coming through the official channel of contract work is the cost of legal entry (Wong \& Anwar 2003: I98). In other words, given geographic contiguity, the existence of alternative social networks and, since January 2007, the possibility for ASEAN citizens to enter the country with a visa issued on arrival, the legal channel with its extra costs often becomes dispensable if not downright undesirable.

Second, the presence of recruitment agencies explains, too, why many legal migrants fall into illegality once in Malaysia. In some cases, migrants were recruited without having a real employer behind their work permits. This means that either they were abandoned once in Malaysia or they were asked to work with a different employer, which meant they were working illegally. In other cases, migrants were brought into Malaysia under forged permits. This would often be done to speed up procedures and lower costs. In practice, it meant that migrants entered and stayed illegally, often without even being aware of it. Finally, the mismatch between the debts incurred to get to Malaysia and the salaries obtained once there have led other migrant workers to the almost intolerable situation of having to work for years just to pay back initial debt. This situation, which is not very different from that of the nineteenth-century indentured workers, has induced many migrants to run away from their employers. By absconding from employers, migrants escaped debts and bondage. However, since work permits are tied to a particular employer, this meant immediately falling into illegality.

The documentary film My Migrant Soul, directed by Yasmin Kabir, tells the illustrative story of Shahjahan Babu, a Bangladeshi migrant who arrived in Malaysia in I993. Babu was recruited by the Bangladeshi recruitment agency Paradise International. He was told: 'If you work abroad, you will be able to bring back money. The more you pay, the more you will earn.' However, the situation in Malaysia turned out to be very different. When he landed in Malaysia, the hotel work he had been promised turned out to be labour on a construction site. The next revelation was that his passport was forged, so that, to add insult to injury, he was illegal. His own words, recorded on a tape he sent back home, say it all: 'I spent so much to come here as a legal worker. And now to serve their [recruiters] interest, they've made us illegal. What are their intentions? Of us five Bengalese, they've separated us all... and put us at different sites, one here, another there. Promising us hotel work, they put us in construction, heavy loads to lift, such hard work... yet I didn't tell you, from seven in the morning till twelve midnight, no wages, nothing. Finally, after a lot of pleading, they fixed our wages at 300 RM. Do we feed ourselves or send money home? Yet, to survive, we'd have stayed. [...] We called our agency. They said: "Get out! We've nothing to do with you." [...] Who will be held accountable for this? Who?' (transcribed by the author from My Migrant Soul). 


\section{5 ... but only as foreigners}

The need to protect the national labour market led to the gradual closure and delimitation of Malaysian borders. However, while the limits of the nation-state became clearer, as did the distinction between citizens and non-citizens, the demand for foreign labour continued to grow in Malaysia. The borders of the nation-state thus became more and more delimited while, at the same time, more and more migrant workers were required. The solution was an institutionalised, government-regulated temporary labour migration system. Like any guestworker programme (see GarcésMascareñas 2004), this system sought to let in migrant workers, but only in places where they were needed and for as long as they were needed. In the Malaysian case, this was accomplished on the basis of three main principles: immobilisation, taxation and temporality of migrant labour.

\subsubsection{Immobilisation of migrant labour}

Migrant labour in Malaysia has always been restricted to particular economic sectors. While in the late I980s, its presence was exclusively permitted in plantations and domestic services, permission was extended in the following decade to the construction, manufacturing and service sectors. The idea behind these limitations has been to restrict the employment of migrant labour to those jobs rejected by local workers. While both employers and trade unions have agreed that local workers should be given priority on the labour market, they have disagreed in identifying the demand for migrant workers. On the one hand, employers have always insisted that locals were 'too choosy' to work in plantations, construction, manufacturing and particular positions in the service sector; hence, foreign labour was required to cover labour shortages in these sectors. On the other hand, trade unions have proclaimed that these labour shortages were not due to a 'genuine' lack of manpower, but to poor wages and working conditions. The result has been a changing migration policy that has opened up these sectors to migrant workers in periods of economic growth, while closing them during economic slowdowns such as in I997-I998 and 2002.

To restrict the presence of migrant workers to specific economic sectors, their inflow has been regulated by work permits (rather than residential status), issued for a specific economic sector and tied to a particular employer. This policy has been backed by the main interest groups. First of all, for employers, the immobilisation of migrant workers has meant the reduction of migrant labour turnover, particularly in sectors with lower wages and poorer working conditions. In other words, it prevented migrant workers from leaving their initial employment to seek 
better job opportunities. Their immobilisation is, moreover, the only legal guarantee whereby employers can recover their initial investments in terms of recruitment fees, medical check-ups and annual levies. Second, trade unions have also been in favour of this policy since it prevents migrants from displacing local workers on the labour market. Third and finally, with this policy the Malaysian state has sought to hold employers responsible for the presence of migrant workers as well as for their return to their countries of origin. This responsibility was reinforced by the 1992 introduction of a mandatory security bond (between 250 to 5,000 RM, depending on nationality and economic sector) that is only refunded to the employer once the migrant worker has left the country. ${ }^{\text {II }}$

The immobilisation of migrant workers has been denounced by most Malaysian and international NGOs. Although most migrant labourers (domestic workers excluded) are protected under the Employment Act, their reliance on a particular employer effectively prevents their seeking redress in the labour or industrial court. Since the Immigration Act clearly states that a migrant worker is only allowed to be employed and to stay in the country within the premises of the enterprise stated in the work permit, if the migrant worker wants to discontinue his or her employment due to abuse or exploitative conditions, or the work permit is cancelled by the employer after having being brought to court, the migrant worker must return home. Sometimes a special pass visa is issued in the latter circumstance, but it must be renewed monthly and does not grant permission to work. Since court cases can take months or even years to conclude, most migrant workers are forced to return home before the end of the trial (Tenaganita 2005: 26-34).

In practice, the immobilisation of legal migrant workers seems to lead in many cases to a situation of 'sanctioned bondage' (see Kassim 1995). Because their mobility is restricted by the work permit, legal migrants must accept the terms and conditions of their contracts, they do not have the freedom to move from job to job and, as we just noted, their labour rights are restricted as their legal presence in the country depends on their employers. In this regard, Kassim (I995: I) concludes that having legal status accentuates, rather than diminishes, the exploitation of migrant workers by employers - that is, legal employment can be counterproductive for the workers. By contrast, illegal migrants are not tied to their employer as there is no agreement signed and they can leave if and when they want. This is evidenced by the high rate of job mobility among illegal migrants (Wong \& Anwar 2003: 220). In this particular aspect, illegality would thus seem to be an advantage to the migrant worker rather than a disadvantage.

At this point it is instructive to refer to more specific situations. Kassim offers two examples to illustrate the difference between legal and illegal migrant workers. The first refers to domestic workers. Most legal domes- 
tic workers live with their employers. In many cases, they do not have a day off and they work many more hours than stipulated in their contracts. At the end of the month, they are paid a fixed salary that, in most cases, does not correspond to the long hours they have been working. In contrast, many illegal domestic workers do not live with their employers. Instead, they rent accommodation in cheap neighbourhoods, such as squatter areas. They work for six to eight households, they are paid by the hour and can rest nights and weekends. The second example refers to legal factory workers. While they are tied to their employers and cannot negotiate their wages or working conditions, illegal workers at petrol pump stations, restaurants and construction sites seem to be relatively better off. Their salaries are higher, they have more contact with people outside the workplace and they can leave if they find better employment (for instance, in sectors with huge labour shortages) whenever they want (Kassim I995: I2-I5).

Given these differences and the impossibility of improving their working conditions by legal means, many legal migrant workers leave their employers and therefore become illegal. This is what is described daily in the Malaysian newspapers as cases of 'absconding' or 'running away'. Although there are no data on the total number of absconders, the general perception is that this is a common phenomenon. For instance, in 1997 an immigration official declared to a Malaysian newspaper that most illegal migrant workers working at the new international airport had run away from plantations in search of better wages (The Malay Mail I2 June 1997). An employer of the Malaysian Palm Oil Plantation observed along similar lines that plantation workers run away as soon as they have a friend working in the construction sector (interview 2I September 2006, Kuala Lumpur). Rudnick (2009: I8I) estimates that 20 per cent of the Bangladeshi women employed in factories and an undetermined higher percentage of Bangladeshi men absconded from their initial jobs. When official data about cases of 'running away' are given, they refer exclusively to domestic workers. In 2005 , 19,406 cases of running away were denounced to the Immigration Department compared to I8,358 in 2004 and I7,I3I in 2003 (New Sunday Times 2 July 2006). According to a representative of the NGO Migrant Care, there were 30,000 cases of running away in 2007, which represented approximately Io per cent of all legal migrant domestic workers in Malaysia (interview II January 2008, Kuala Lumpur).

On the basis of these data, many recruitment agents and even government officials suggest that employers not give migrant domestic workers a day off each week. Agents and politicians commonly argue that domestic workers 'easily fall in love' or can be 'easily manipulated'. However, if we take into account how their situation is even more fragile than that of the other legal migrants, we might well conclude that 'absconding' is the only real alternative they have to improve their situation. Domestic 
workers are not included in the Employment Act and neither are minimum wages or minimum working conditions specified for them. As alleged 'family members' and 'non-workers', their bargaining capacity is even more limited. What can they do if they are not paid? Or if they have to work 20 hours a day, or cannot have any day off? Or if they are paid much less than promised? In many cases, they run away. As Beeman argued (I985: I73) about Indian workers in colonial Malaya in the late nineteenth and early twentieth centuries, since they have no means of bargaining, 'running away' or 'absconding' may become an individualistic way to try to improve their situation.

In the practice of absconding, past and present once again mirror each another. From I9I2 to I922, almost one third of all Indian workers deserted from the plantations (Beeman I985: I74). However, there is also major difference. In the past, with the legally sanctioned end of indentured servitude, absconding was hardly germane since migrant workers were free to leave and join an employer who offered higher wages or better conditions. Although employers continuously asked the colonial authorities to immobilise migrant workers by law, their claims went unheeded. As the High Commissioner said in I9I5: 'We should have no indentured labour, and I would prefer to go the other way, and that is to tell the labourer he is not tied for a month and can go off any day' (in Parmer I960: I49). Of course, law does not always make for reality. Despite this legislation, labour bondage continued. Unable to obtain favourable legislation, individual plantation employers devised their own strategies to keep workers on the estates. For instance, a labourer who was due one or more months' wages was deemed unlikely to quit or abscond from the estate (Parmer I960: 150). The main difference is that, in the past, this bondage was not sanctioned and reinforced by law. Migrant workers were not tied to their employers either by contract or work permit. Moreover, in case of absconding, they did not become illegal - which is to say, they were not susceptible to being prosecuted and deported by colonial authorities for the simple reason of their labour mobility.

\subsubsection{Taxation of migrant labour}

Together with the immobilisation of migrant workers, taxation seeks to control immigrant presence in Malaysia. Following the example of Singapore, a levy was imposed in 1992 to reduce the employers' reliance on migrant workers. As stated by the Human Resources Minister in I99I, the levy aimed to 'control the influx of cheap and unskilled labour into the country' and to 'keep a close check on the workers' (New Straits Times I6 May I99I). This was done by imposing an annual tax per migrant worker, according to their economic sector and skills (see Table 3.4). The logic behind this variation was to impose a higher levy in sectors where local workers 
could still be found and a lower one in those where foreign workers were really in demand.

Table 3.4 Levies (in RM)* imposed on low-skilled foreign workers in 1992 and 2006

\begin{tabular}{ccccc}
\hline Year & Sector & & & \\
\hline & Plantation & Service & Construction & Manufacturing \\
1992 & 369 & 360 & 420 & 420 \\
2006 & 540 & 1,800 & 1,200 & 1,200 \\
\hline
\end{tabular}

Sources: Pillai (1992: 60); data for 2006 obtained directly from an immigration officer (interview 6 October 2006, Putrajaya)

* The exchange rate for the Malaysian ringgit (RM) (May 2011) is 1 EUR $=4.33$ RM.

As with all migration policies in Malaysia, the levy on foreign workers has been adapted to the different and changing requirements of the labour market: in periods of higher unemployment the levy has been raised to protect national workers while in periods of lower unemployment, reduced. This flexibility, however, is not free of contradictions. Protection of the national labour market has not always coincided with economic requirements. For instance, in January I998, the levy was increased to 'discourage the influx of foreign workers in the country and to reduce foreign labour dependence' during the economic downturn that followed the SouthEast Asian financial crisis of 1997 (New Straits Times 2 January I998). However, in December of the same year - once again in tune with Singaporean migration policies - the levy was reduced in some sectors (particularly in the export industries) to 'ease the burden on employers' and promote economic recovery (New Straits Times 28 December I998). This contradiction is also manifested within the government itself. While, in I992, the Labour Department favoured the levy in order to protect local workers, the Primary Industries Minister expressed his doubts: 'The plantation sector must ultimately be able to make use of foreign labour to its advantage. While remuneration of foreign labour should not be such that it would displace the use of local labour, it would certainly not be in Malaysia's advantage if foreign labour turned out to be more expensive than local labour' (New Straits Times 27 May I992).

The same conflict of interests regarding the introduction of the levy also arose between the employers' organisations and trade unions. On the one hand, employers' organisations complained that the levy was too high, would cut profits and therefore reduce general economic growth. As stated by the president of the United Planting Association of Malaysia: 'The plantation sector is plagued by numerous problems, threatening its very existence. The labour shortage and escalating production costs against a backdrop of poor commodity prices are only some of the problems the plantation 
sector cannot hope to resolve on its own. This is why we continue to appeal to the government to be more sympathetic and sensitive to the plight of the agricultural sector as and when it reviews the various policies affecting plantation companies so that their continued growth can be ensured. For instance, the proposed levy on foreign workers will further aggravate the problems facing the sector' (Business Times 23 May I99I). On the other hand, trade unions welcomed the introduction of the levy as a first step towards the protection of national workers. Since I992, in its efforts to overcome once and for all the displacement of national workers on the labour market, the Malaysian Trade Union Congress (MTUC) has put pressure on the government to raise the levy and impose a minimum national wage. The official response has always been the same: both options would be detrimental for economic growth.

If we look at how the levy was imposed and justified, we might conclude that it indeed resulted from a compromise between the protection of national workers and the promotion of economic growth. In particular, the official message was that the levy was needed to protect local workers, yet it should be kept as moderate as possible so as not to disrupt the Malaysian economy. In practice, however, the compromise was difficult to maintain. As we have seen for other policy measures, the device of the levy ended up giving priority to the demands of employers. This came about as a consequence of a double (interconnected) change. First of all, employers started to deduce the levy from workers' monthly wages. In I993, just one year after the introduction of the levy, the government officially recognised the employers' right to transfer the burden of the levy to migrant workers. Second - and partly as a consequence of this - the levy shifted from being a tax imposed on employers who relied on foreign labour to being an income tax paid by migrant workers. The very day the Immigration Department started considering the possibility of allowing the deduction of the levy from migrant workers' wages, its objective was redefined. As an officer from the Immigration Department stated: '[T]he levy is to ensure that foreign workers make financial contributions, just like local workers, for the development of public facilities and social amenities that they enjoy or use while working in Malaysia' (New Straits Times 2 January I993).

This shift in the practice and meaning of the levy featured very clearly in my interviews. For instance, as the president of the Master Builders Association Malaysia said: 'The levy is paid by the employer and then deducted from wages. Why should the employer pay the levy? It wouldn't be fair. If the worker earns RM 1,200 a month, he can pay RM 100 a month, can't he? It's not a burden for the worker. Moreover, it is a way of putting foreign workers on an equal footing with locals, who pay income taxes' (interview 22 September 2006, Kuala Lumpur). An Immigration Department officer described this process of transformation as follows: 'The levy was first introduced to discourage employers from taking on foreign workers. Now it works 
in this sense only for the service sector. We have recently increased the levy to 1,800 RM. But for the other sectors it's different. When we introduced the levy, the employers turned it round to work in another way. They started to deduct it from the workers. How to control this? It is impossible' (interview 6 October 2006 , Putrajaya). Although this immigration officer was highly conscious of employers' misuse of the levy, he immediately accepted the shift, stating: 'Now the levy is a kind of tax for foreign workers. It also functions as a security bond for the government. [...] Every week we send back a few hundred illegal migrants: to Indonesia, normally by ferry; to Thailand, by road; to the Philippines, by plane. So all this is very expensive. The levy is used partly to cover all these expenses' (interview 6 October 2006, Putrajaya). ${ }^{\mathrm{I2}}$

In contrast to what the employer quoted above believed, Tenaganita has systematically denounced the fact that the levy imposes a great burden on migrant workers. One of the NGO's members observed how '[s]ometimes foreign workers get a very low salary and then the levy is deducted from it as well as the food. At the end of the month, they sometimes only get RM75 or RM150 and, of course, they don't want to keep working for nothing. But if you go to the Immigration Department, they tell you that they have to work until they pay all their expenses in terms of insurance, annual levy, et cetera' (interview 4 October 2006, Kuala Lumpur). The payment of the levy led many migrant workers (mainly Indonesians) to strike in protest against their employers. As on other occasions, the government responded to these protests by arguing (with an implicit threat) that migrants should 'forward their grievances through proper channels' and 'learn to respect the Malaysian laws', and 'if they are not disciplined, their work permits will be revoked and they will be deported' (New Straits Times Io May I996; I2 September I996).

In practice, the introduction of the levy has had a twofold effect on migrant workers' lives. First, it has increased their dependence on employers since now their bondage is not only defined by the conditions of the work permit (as described above), but also established in practice through the debt that restarts each year when the employer advances payment of the levy and then makes monthly deductions from the migrant workers' wages. To be more precise, if migrant workers leave their jobs, the employer loses the levy amount that remains to be deducted from their monthly wages. This has compelled employers to retain foreign workers' papers so as to prevent them from running away. Although this practice is clearly not permitted by the Immigration Act, once again it has been accepted by the Immigration Department. In the words of the National Union of Plantation Workers president: 'Foreign workers are tied to their employers. Why? Because employers pay in advance for the costs (levy, insurance, et cetera), so they consider themselves to have the right of ownership' (interview 9 October 2006, Kuala Lumpur). The second effect is that, yet again, the levy pushes up the price of legality. It is thus more expensive to be a legal migrant than an illegal one. Most Malaysian scholars have 
pointed out this difference as one of the main reasons migrants prefer to remain or become illegal (Battistella 2002: 363; Pillai 2000: I42; Hugo I995: 277; Ruppert I999: 33; Kassim I993a: 5-6, I993b: 6, I994b: 3-4, I995: 7, I996: 2, I997: 5; Bagoes Mantra I999: 63; Wong \& Anwar 2003: I92-I98). This was also one of the main reasons given by illegal migrants themselves in a survey of Ioo respondents in Peninsular Malaysia (see Wong \& Anwar 2003).

\subsubsection{Temporality of migrant labour}

There is general consensus that migrant workers should remain only temporarily in Malaysia. As stated many times by employers, trade unionists and government officials, they are 'temporary workers but not migrants', or 'they came here to work, not to get the permanent residence permit' (interviews I3 September 2006 and 20 October 2006, Kuala Lumpur). As in the past, they are still considered 'birds of passage'. Their temporality is, however, of a different nature. While, in the late nineteenth and early twentieth centuries, migrants were only deported in case of unemployment or health problems, since the late ig80s, migrant workers have come to Malaysia with short-term contracts that may be extended for a maximum of five to seven years. The temporality of contemporary migrants seeks not only to reduce social security costs, but also to prevent their incorporation into Malaysian society (see Garcés-Mascareñas 2008a). We might say, then, that the presence of migrant workers in Malaysia has been governed by different types of temporality.

The first type is defined, as in the past, according to labour demands. While in periods of economic growth, new migrant workers are recruited and those already in Malaysia are allowed to stay, in times of economic downturn, new recruitments are frozen and migrant workers in the hardest-hit sectors have to leave. By repatriating them, the Malaysian government seeks to reduce the costs of unemployment and, at the same time, give priority to employing local workers. Perfectly illustrating this logic are the mass repatriation programmes that followed the financial crisis of I997. While, in the early I990s, the number of migrant workers increased, in keeping with labour demands, in I998, the Malaysian government immediately halted the issuance of renewals. It was announced that 200,000 migrants, mostly working in construction, would probably be laid off (New Straits Times 6 December 1997) and that work permits for 700,000 migrants in the construction and service sectors (except domestic workers) would not be renewed on expiry (New Straits Times 9 January i998). Apart from exceptions made for some categories, work permits that expired in August I998 were not renewed, which meant that I59,I35 migrant workers had to leave the country (Wong \& Anwar 2003: I8I). As happened with the bans on entry, this freeze was lifted a few 
months later. Once again, the measure was justified by the need to safeguard economic growth.

The ongoing tension between, on the one hand, protecting local workers and, on the other, promoting economic growth through the importation of migrant labour has never been resolved. The strains on the system appeared yet again when local unemployment rose from 3.I per cent in 2000 to 3.7 per cent in 200 I (Kanapathy 2004: 395). In response to this increase and following pressure from trade unions, the Malaysian Parliament passed legislation that set a maximum of three years for the period in which a migrant might hold a work permit. This changed the status of many migrant workers from 'legal' to 'illegal' practically overnight. With the implementation of this policy, those workers who had been covered by work permits for more than three years were immediately deemed 'illegal' and repatriated at three months' notice. However, even while thousands of migrant workers were being repatriated to their countries of origin, the government continued to allow new recruitments in the agriculture sector (New Straits Times 5 November 200I). The old argument was trotted out yet again: labour shortages in these sectors could not be covered by local workers and production could not be stopped without affecting the whole national economy.

A second type of temporality is linked to migrant workers' health. In contrast with that defined by labour demands, this second type is applied at the individual level by repatriating any migrant workers deemed 'medically unfit'. Being 'unfit' means having diseases such as hepatitis B, tuberculosis, syphilis or HIV/AIDS and, for female migrant workers, being pregnant. As in the past, this policy seeks to reduce social costs (both in terms of the social security system as well as regarding the spread of particular diseases) while maximising the foreign labour force by keeping in the country only the fittest workers. In the case of pregnant women, the policy aims to avoid reproduction costs as well as the settlement of migrant workers in the country. Unlike other types of data, there is a great deal of available information on the number and characteristics of 'unfit' migrant workers. This may be related to social perceptions and the political will to associate migrant workers with diseases and other 'social problems'. To be more specific, I8,I54 cases of 'medically unfit' migrants (or 3.6 per cent of the total foreign labour force) were reported in I998, 7,276 in I999, 6,9I4 in 2000, 9,284 in 2001 and 8,827 in 2002 (Kanapathy 2004: 399). In 2004, the highest number was found in the agriculture sector, with 6,500 cases or 35.2 per cent of all migrant workers employed in this sector (The Malay Mail 9 December 2004).

Finally, migrant workers are not allowed to stay in Malaysia for more than five to seven years. This third type of temporality is also implemented at the individual level and again aims to prevent migrant workers' settlement in the country. The logic is to ensure that migrant workers 
come only to work or that they remain as 'pure labour' without becoming settled migrants. This results in a migrant labour system that is constantly renewing its labour force. As described by the Malaysian Employers Federation president: 'Foreign workers are only allowed to work. They come to work and, once they finish, they have to go back. They come and go, they come and go, all the time' (interview I3 September 2006, Kuala Lumpur). While assuring a flexible, external labour supply, this constant influx and outflow of migrant workers seems to militate against productivity. As this interviewee went on to explain, every year about 400,000 or 500,000 'fresh' migrant workers enter Malaysia. Employers must train them over and over again without being able to retain their skills for the company's benefit. Following employers' complaints, 'certified skilled workers' are exceptionally allowed to stay for ten years. However, in the end, the result is the same: they always have to leave. Despite its impact on productivity, this is accepted by all parties. As the Malaysian Employers Federation president puts it: 'We are not supposed to have these people here forever, are we?' (interview I3 September 2006, Kuala Lumpur).

The only migrant workers not required to leave Malaysia after five, seven or ten years are domestic workers. According to the government guidelines for foreign domestic workers, they can keep renewing their work permits until they are 45 years old. However, as many interviewees informed me, they can stay in Malaysia as long as they want since their birth certificates can easily be falsified. This does not mean that they can officially settle in the country and get a permanent residence permit. As an interviewee from a recruitment agency specialising in domestic workers states: 'The government is not obliged to give you permanent residence. It depends on what you have done. What is your contribution to the nation as a maid? I don't see any reason for giving them permanent residence. This is for engineers (interview I6 September 2006, Kuala Lumpur). Hence, domestic workers, unlike other migrant workers, can be - paradoxical though it may sound - eternal temporary migrants in Malaysia.

In practical terms, these three forms of temporality have had a triple effect. First of all, as I noted above, they have brought about a continuous labour turnover that may disrupt productivity. Some employers, however, did not see this as a problem since most migrant workers have low-skilled jobs. Moreover, as one recruitment agent remarked, new labour is cheap labour: 'We don't like to depend on them. If they become skilled workers, they can ask for more money. Unskilled new workers are much cheaper' (interview 29 September 2006, Kuala Lumpur). Second, it has increased costs of the whole labour migrant system since old migrant workers must be sent back to their countries of origin while new ones must be recruited and brought in. Finally, this temporality introduces a factor of unpredictability into the supply of migrant labour. Employers can hardly count on the future number of migrant workers they will be allowed since their 
presence in Malaysia depends on the general economic performance.

Naturally, this unpredictability affects migrant workers, as they can be required to leave at any moment. This is particularly hard on the migrant if we consider how many have paid considerable money to get to Malaysia. What happens to those migrant workers who have sold their properties back home or incurred debts in order to migrate when they are suddenly ordered to go back because they are no longer required, or because they are ill or get pregnant? Among my interviewees there was a general agreement that, in many cases, they decide to stay in Malaysia even if this entails becoming 'illegal' (see also Rudnick 2009: I77). This is also illustrated in the many interviewees in Wong and Anwar's (2003) survey on illegal migrants, for example the 24 year-old unmarried woman from a rural district in Aceh. After working three years in a factory, her contract was not renewed and she was supposed to go back home, though instead ran away and sought refuge in her sister's home in a suburb of Kuala Lumpur (ibid.: I92). Although this scenario is frequently observed, there are little, if any, data to illustrate it, possible owing to a political will to underscore certain aspects of the situation (such as the incidence of particular diseases among migrant workers) while obscuring others (such as the number of legal migrants who move into illegality).

\subsection{Turning illegal migrants into guestworkers}

The illegality of migrants in Malaysia challenges the core principals of its guestworker policy. It calls into question how the recruitment of migrant workers in their countries of origin stays in keeping with the numbers and places determined by the state and, once they are in Malaysia, the immobilisation, taxation and temporality of migrant labour. Indeed, unlike legal migrant workers, illegal migrant workers are recruited inside Malaysia, they can and do move from one job to another, they do not pay taxes and it is much more difficult to make them leave the country at a moment's notice. In short, illegal migration is not as malleable, manageable or controllable as legal migration. This seems to pose a dual problem to the state. First, the presence of illegal migrant workers blurs the borders of the national labour market. Second, illegal migration is perceived as a security threat portrayed in terms of crime, diseases, political and religious activities, and an ethnic and cultural hermeticism that sows the seeds of discord. In more general terms, it has been seen as an 'infiltration' of 'aliens' or 'uninvited guests' within the territorial borders of the nationstate. In this context, different regularisation programmes were implemented (in I989, I991-1992 and I996) so as to re-include within the stateregulated labour system those migrants who had entered illegally or had become illegal. The official argument has always been that regularisation 
programmes 'enable the government to keep track of their number, location and origin besides giving them an opportunity to obtain protection under the labour laws' (Business Times 25 July I996).

\subsubsection{First regularisation programme}

In January I989, a first regularisation programme was launched to legalise Indonesian workers in the plantation sector. This programme followed concerns that an increasing number of illegal migrants was having an impact on crime, housing, diseases, family formation and permanent settlement. Moreover, the MTUC and the Chinese opposition DAP had decried the fact that local workers were being displaced by (mainly Indonesian) illegal migrants. As a counterpoint, employers argued that labour shortages in plantations could not be covered by local workers. In response to these claims, the Malaysian government sent directives to employers in the plantation sector obliging them to register and regularise their illegal migrant workers. Both the MTUC and the DAP lost no time in accusing the government of recognising 'illegal migrants' and thus violating its own immigration laws. Furthermore, they claimed that wages and benefits for local workers could be 'suppressed' if illegal migrants were allowed to carry on working in the estates (The Star 5 January I989; 7 January I989). For the Indonesian government, this regularisation programme was interpreted as an end to the exploitation of Indonesian workers by 'unscrupulous employers' in Malaysia (Tempo I6 July I988).

Under this first regularisation programme, employers were required to give the Labour Ministry the names of the illegal migrant workers they employed. The Labour Ministry then determined if the submitted list was acceptable and whether the shortage was 'genuine'. Once its approval was given, the list was submitted to the Indonesian embassy to ensure that they were bona fide Indonesian citizens without any criminal record. Finally, illegal migrants were to be sent to the port city of Malacca, for subsequent return to Sumatra (Indonesia), where they were to be issued valid Indonesian travel documents and the Malaysian work permit, after which they were to be returned to Malaysia as legal migrant workers. The trip to Indonesia took six days, and the fee, payable to the Indonesian embassy for administrative costs and round-trip travel, was RM 250 (ibid.). Although estimates of the numbers of illegal migrants were much higher, no more than 20,000 Indonesian workers were legalised under this programme. In the state of Pahang in Peninsular Malaysia, it was estimated that over 40 per cent of illegal migrants working in plantations were not legalised in May I990 (The Star I8 May I990). These figures were corroborated by officials of the Malaysian Agricultural Planters Association, who confirmed that many plantation employers did not regularise their migrant workers (Kassim i994b: I04). 
The reasons for such limited results are said to be multiple. First of all, many employers ignored the programme because they were unwilling to incur the expenses involved in the legalisation exercise (ibid.). In addition to the expenses paid to the Indonesian embassy (RM 250), employers were also expected to pay another RM 275 for a bank guarantee and the costs of acquiring a work permit. Second, the legalisation process took about a week, during which time production at the plantations would be adversely affected by the absence of migrant workers (Kassim I993a: 7, I993b: 8). Third and finally, it has been observed that the Indonesian immigration officials were completely unprepared for the volume of requests for documentation. While, at the beginning, procedures could be carried out in Malaysia through a private agency, the common use of fake identities led Indonesian authorities to require migrant workers to travel personally to Indonesia. The result was chaos, not only affecting the regular ferry lines between Malaysia and Indonesia, but also the special centres set up in Indonesia to deal with the issuance of such documents (Jones 2000: 2O-2I).

\subsubsection{Second regularisation programme}

Despite these limited results, a second regularisation programme was announced in November I991. Initially, it was directed only at domestic workers, who were given a month to acquire legal status. The response was so positive that the government extended the programme to 30 June I992 in order to cover illegal migrant workers in the construction and plantation sectors as well. Following mounting pressure from employers, in April I992, illegal workers in the manufacturing and service sectors were also allowed to register under the programme. The official argument for launching this second regularisation was that it would bring illegal migrants' salaries and work conditions on par with those of local workers, thereby making it possible to protect local workers from unfair competition within the labour market: '[T]he objectives are clear. Malaysians must not be deprived of any available jobs in the country; the flow of illegal workers must be stopped; and illegals already working in the country need to be legalised and regulated so that those who are really needed are allowed to stay and those who are not will be asked to leave' (Business Times II January I992). Despite these arguments, trade unions yet again opposed the regularisation programme. According to them, it would open the door to labour migration into Malaysia.

This time, the procedures were greatly simplified. Employers had to register their workers at 30 registration centres set up by the Immigration Department in Malaysia. The illegal migrant then had to apply for a temporary travel document at the Indonesian embassy in Kuala Lumpur and, after a medical check-up, temporary work permits were issued by the 
Immigration Department. The demand was overwhelming. When the registration period ended on June 1992, 442,276 workers had registered. Of these, 50 per cent were in the construction sector, 20 per cent in the plantation sector, 9.7 per cent in the domestic sector, 8.5 per cent in manufacturing, 2.6 per cent in restaurants and 4.6 per cent in trading. The largest number was from Indonesia (83.2 per cent), but there were also registered migrants from Myanmar ( 6 per cent), Bangladesh $(5$ per cent), the Philippines (2.5 per cent) and India (2.2 per cent). Over 45 per cent of these workers were employed in the Klang Valley in the state of Selangor and Kuala Lumpur, one of the country's most industrialised areas (Kassim I994a: 4).

Despite this initially overwhelming response, by the end of I992, only about 20 per cent of those who registered eventually applied for work permits (The Star 26 October 1992). Hence, 80 per cent of the 442,276 registered migrant workers remained technically illegal, as they did not obtain the work permit. Again, the reasons for this seem to be diverse. First of all, in addition to the initial costs to be paid for the issuance of the work permit (RM 48) and security bond (RM 250), employers were expected to pay an annual levy (introduced some months before) of RM 420 for each plantation worker, RM 500 for each construction worker and RM 360 for each domestic worker. The payment of the levy was required to obtain the work permit. Moreover, from I99I on, legal migrant workers enjoyed the same wages and benefits as local workers. This consequently increased the costs associated with legal employment (Jones 2000: 23; Hugo I993: 62). As for the regularisation programme of I989, it seems that many employers did not cooperate due to the economic costs associated with the legalisation of their migrant workers (Jones 2000: 23; Hugo I993: 62).

Second, for the registration of workers and acquisition of travel documents, the Indonesian embassy authorised, first, twelve and, eventually, twenty Malaysian labour recruitment agencies to register workers and obtain their travel documents. These agencies were given permission to charge RM I80, a sum that, in the wake of employers' protests, dropped to RM I35 and RM II5. In addition to pushing up the costs of regularisation, in many cases these agencies did not process travel documents on time, thus rendering thousands of Indonesian migrants illegal once again. The functioning of these agencies gave rise to many complaints among employers. Several stated that they were not given details of the payment and that some agencies had claimed that the Indonesian embassy collected RM I8O (instead of the required RM 60) to issue the travel document and for other expenses. Other employers said that they had no choice but to deal with the agencies they felt had monopolised this sphere: 'I was told I will not be entertained if I were to go to the Indonesian embassy myself to apply for the identification papers for my Indonesian workers. Neither would my 
employees be entertained if they were to go there themselves. Just imagine the amount of money these agencies will collect based on recent estimates that there are between 300,000 and 500,000 illegal workers in the peninsula alone' (in Business Times 23 December I99I).

Third and finally, there were also indications that the Malaysian government was trying to reduce the number of 'legalised' migrant workers. For instance, in July I992, just after the deadline for registration, the Home Minister declared that 30 per cent of all those who registered were found to be HIV-positive. Since a certificate of good health was required to get the work permit, such figures jeopardised the final regularisation of many migrants. As observed by Jones (2000: 24): 'the statistically impossible rate of HIV infection announced by the Home Ministry seemed suspiciously like a pretext for denying legal status to over I००,००० workers and thus both keeping their numbers down and reinforcing the negative image of Indonesian workers in the public at large'. However, after being challenged by the World Health Organization, these statistics were immediately corrected (Jakarta Post 29 July I992). Accordingly, the Health Minister told employers not to panic over his own statement and clarified that only 48 HIV positive cases had been found among all registered migrant workers. However, although these cases represented a very small proportion of all migrant workers in Malaysia, the Health Minister advised employers 'to take their maids for medical tests immediately to ensure that they are free of diseases' (The Malay Mail 3I July I992). His alarmist warning clearly shows how control over migrant workers includes strict monitoring of their very bodies and that this control systematically intensifies when applied to migrant women's bodies (see Ong I99I: 29I).

\subsubsection{Regularising from detention camps}

From I993 to I996, no particular regularisation campaign was launched. However, the government pushed for recruitment of illegal migrants from detention camps. By freezing the recruitment of new migrant workers and therefore forcing employers to recruit from detention camps - where arrested illegal migrants were awaiting deportation - the idea was to absorb those approximately 200,000 registered migrant workers who had not obtained the work permit after the regularisation drive of I992 (Business Times I4 April I993). In addition, this policy sought to cut costs of deportation as illegal migrants would be re-deployed without having to go back to their countries of origin. The procedures, this time, were quite simple. Potential employers could go to detention camps to select the workers they wanted, after which they had to go to the nearest immigration office, present the necessary documents, settle the required payments and apply for work permits. Of the 54,I55 detained migrants in I992-I993, in March I994 27,353 had been released after being offered jobs (The Malay Mail I 
March I994). In subsequent years, the proportion of migrant workers recruited in detention camps was much lower. For instance, in I996, of the 37,000 illegal migrants in camps who were available for employers, only 3,000 were hired (New Straits Times Io October I996).

The reasons offered to explain these limited results were once again similar to those adduced for the regularisation programmes of I989-1990 and I99I-I992. Generally speaking, neither employers nor recruitment agencies were in favour of such policy. In fact, they had a long list of complaints. Employers claimed that the costs of recruitment from detention camps were higher than those entailed in recruiting new migrant workers in their countries of origin. Apart from the levy, they were required to pay RM 500 for the deposit or security bond, RM 60 for a visitor's pass, RM 20 for a visa, RM 200 for a passport, RM 300 in compound, RM 200 in agent fees and RM I20 in medical bills (New Straits Times I8 June I993; 29 June I996). Moreover, both employers and recruitment agencies argued that migrant workers recruited from detention camps were much more mobile than 'fresh' migrant workers since they were familiar with the Malaysian labour market and therefore often absconded in search of better jobs (Business Times I3 April I993). At the end of I993, the Deputy Home Minister recognised that nine out of ten Indonesian migrants who had been caught and then released from detention camps to work for specific employers ran away within three months. In the minister's words: 'These immigrants usually have extensive networks of friends and even relatives locally to help them merge into the woodwork' (New Straits Times 23 November I993).

Employers in the manufacturing sector also complained that migrant workers in detention camps did not possess the required skills to work in manufacturing (Business Times 9 July I994). They argued, in particular, that female workers were especially needed in the electronics and garment industries while most illegal migrants in detention camps were men (New Sunday Times 2 May I993). Another claim by employers and recruitment agencies was that most migrant workers found in detention camps were ineligible for employment because they did not fulfil the Immigration Department's conditions. For instance, in many cases they did not have valid passports. One employer reacted by wondering: 'What's the point of asking us to go to detention centres to look for foreign workers when there are not enough eligible ones to go round in the first place?' (The Malay Mail I2 July I994). Finally, the Minister for International Trade and Industry argued that recruiting agents gave 'wrong' reports to company heads concerning their books, so that migrant workers would be sourced through employment agencies rather than being hired from among detainees in immigration camps (Business Times Io October I996). The reason, given by one agent, was purely economic: 'We will not want to handle the matter unless we can charge a service fee. This is because payment is usually made by 
the foreign worker when he leaves his country of origin. Workers detained here in Malaysia may not be able to pay any fee' (New Straits Times 29 April I993).

\subsubsection{Third regularisation programme}

In a new attempt both to control migration as well as to meet escalating demands for migrant labour, a third registration effort began in I996 to register and legalise illegal migrant workers from Indonesia, Thailand, the Philippines, Bangladesh and Pakistan. Under this new programme, employers in the agricultural and plantation sector and eventually in the manufacturing, construction and service sectors were assigned the period from July io until December 3I to register and legalise their illegal migrant workers. An extended 'amnesty' allowed workers who had failed to register by the deadline and had been caught by police to leave the country without prosecution and, after having paid a fine and obtained the stipulated documentation from their home country, to return to Malaysia as legal migrant workers. At the same time, as in previous years, a freeze on hiring new migrant workers was imposed as a way of pushing employers to legalise their workers or re-employ those who had returned to their countries of origin. By January I997, when the registration drive was completed in Peninsular Malaysia (the state of Sabah conducted a similar exercise during the first half of I997), 423,I80 illegal migrant workers had registered (New Straits Times 3 January 1997). The highest number was in the construction sector, followed by manufacturing, domestic work, service and plantations (New Straits Times 2 January I997).

Despite the lack of data regarding the number of registered migrant workers who obtained the work permit, there are indications of majorly problematic red tape within the Immigration Department. For instance, in July I997, employers denounced the fact that many workers had not received approval notification cards and therefore could not apply for their work permits. As regularisation programmes were always followed by periods of intensified police raids, employers were particularly concerned because their migrant workers, who remained technically 'illegal', could be detained and deported (The Malay Mail 23 June 1997). Again, in September 1997, the state of Selangor reported that employers of more than 7,000 migrant workers, whose passports had been submitted for registration, had not collected them (New Straits Times 27 September I997). If we take into account that 28,000 migrant workers had been registered in this state, the number of uncollected passports is a good indicator of the proportion of registered migrant workers who might not have been regularised in the end.

Although the number of 'registered' migrant workers was as high as in the previous regularisation exercise $(423,180$ in I996 compared with 442,276 in I99I-I992), this time the government was particularly disap- 
pointed with the results since, after the regularisation programme came to an end, it estimated that there were still more than one million illegal migrants in the country (The Malay Mail 27 January I997). Even prior to this disappointment, the government had stated that it would not be carrying out any more campaigns to legalise migrants. In other words, this regularisation campaign was seen as 'the end of the relative leniency, law-wise, towards the problem of illegal migrants' (Business Times 7 January I997). From then on, higher penalties for illegal migrants as well as for human smugglers and employers (through the amendments of the Immigration Act in I997 and 2002), mass deportation and 'voluntary return' campaigns became the central policy instruments for cutting down illegal migration in Malaysia. In short, the 1996 regularisation programme was the swan song of legal recruitment of illegal migrant workers in Malaysia (see Wong 2006).

\subsubsection{From regularisation to deportation}

As we shall see in the next section, this policy shift was not contradictionfree. On the one hand, the gradual criminalisation of illegal migration and its being whipped up into a security issue led the government to stop recognising, registering and legalising illegal migrants, who then had no option but to return to their countries of origin. In exceptional cases, as with the so-called 'amnesties' (to go home) from I 998 on, they could leave the country without being fined or prosecuted. Here, the government seemed to be accepting precisely what trade unions and opposition parties had denounced during earlier regularisation campaigns: regularising illegal migrants entailed 'going against the law'. On the other hand, mass deportation campaigns (voluntary or not) led to huge labour shortages that were not easily covered by local workers or freshly recruited migrant workers. As soon as one 'security' issue was dealt with, another real problem of state security reared its head. These labour shortages were seen as the cause of serious economic losses and, hence, as a danger to the whole national economy.

In 2005 , the ongoing tension between the imperative of deporting illegal migrants and economic dependence on their work pressed the Malaysian government into permitting Indonesian illegal migrants to return to Malaysia after having left the country during the voluntary repatriation programme of 2004 . To encourage employers to take former illegal migrants, a freeze on newly recruited migrant workers was simultaneously imposed. For a period of three months, only former illegal Indonesian migrants were thus allowed to enter Malaysia as legal migrant workers. This was in clear contradiction of a policy that explicitly no longer recognised illegal migrants. As one writer put it: 'On the one hand, the government has repeatedly said that it is determined to rid the country of illegal 
foreign workers. On the other hand, if you have been hiring illegal workers, the government will reward you by showing you a fast lane to bring back your former illegal workers legally. If you are a low-abiding employer, you will have to wait for at least three months before you can apply through the proper channels for new foreign workers' (New Straits Times 3 February 2005). The main problem was that the freeze on new recruitments was not accompanied by the anticipated return of former illegal migrant workers. Only 500 of the 500,000 illegal migrants who left Malaysia during the repatriation programme of 2004 had come back a few months later (The Malay Mail 7 March 2005).

According to the Malaysian newspapers, these limited results were mainly due to 'the inordinate delay by Indonesian authorities in processing documents of the illegal workers and a hefty processing fee' (ibid.). My interviews suggest that official procedures, in both Malaysia and Indonesia were very time-consuming, problematic and costly. For instance, a Malaysian immigration officer explained that many Indonesian workers could not return because of technical problems: 'The biometrical system that we used did not work. The fingerprint often did not coincide with the one we took from them before they left. We did it to make sure that the person who came back was the same one who had left. But then many fingerprints did not coincide. Why? Either the ones who came back were not the same or our system did not work properly. For example, we soon realised that our system did not recognise sweaty fingers' (interview 6 October 2006, Putrajaya). A government agency staff member described the whole process as follows: 'There were too many tolls. So it was a long process and people started to make money, for instance, agencies in Indonesia started to charge to process the passport. In Indonesia workers had to go through different agencies to get the passport. All of them wanted to get money. Then it was very difficult, too, to go through Malaysian procedures. Everything was too costly. Foreign workers were again object of abuse. Again, the human trade became very lucrative. For instance, for the visa, workers had to pay about RM 400' (interview I2 October 2006, Kuala Lumpur).

In general terms, the implementation and results of regularisation programmes in Malaysia highlight three main points. First, they reveal the resistance to regularisation. According to information given in newspapers and other published sources, employers resisted regularising their migrant workers since registration and the other requirements of legal employment were costly and time-consuming. It also seems that the migrant workers resisted regularisation as, in many cases, they had to cover a major part of the expenses themselves while the benefits of being legal were far from being always evident. This would explain running away cases among those migrants recruited in deportation camps. Second, the results of regularisation programmes must be understood in relation to the bureaucracy as well. Long, complicated procedures replete with red 
tape-ridden obstacles and delays have also determined the outcome of the regularisation programmes. Apart from Malaysian bureaucracy, the bureaucracies and political will of the countries of origin played equally important roles. Since migrant workers are required to process several documents in their embassy or homelands, the way this is done and the end results depend on the possibilities, limits and constraints imposed by the bureaucratic and political apparatus of the sending states. Third and finally, complicated and time-consuming procedures have led to a demand for agencies or middlemen who can help the process by bridging the gap between employers and the state apparatus. However, they increased the costs of regularisation while often making procedures less transparent and even more uncertain.

\subsection{Detaining and deporting 'illegals'}

Together with regularisation programmes, continuous amendments of the Immigration Act to penalise illegal migrants and highly publicised deportation campaigns have sought to reduce illegal migration by detaining, imprisoning, caning and finally deporting illegal migrants. The basic aim has been to persuade legal migrants to remain legal and illegal migrants to regularise or return to their countries of origin. At the same time, as we shall see in the following paragraphs, these policies have had a twofold symbolic effect. First, they have sought to give an impression of control and therefore to bolster the image of the state as guarantor of the national borders. Second, by detaining, penalising and deporting migrants, these policies have criminalised them, irrespective of their legal status.

\subsubsection{The first deportation campaigns}

The first deportation campaign was launched by the Malaysian government after it introduced the first comprehensive work permit policy in I99I and the regularisation programme of I99I-I992. The ideological thrust of this first deportation campaign was to 'clear the country of illegals' before embarking on the new labour migration policy. Moreover, by letting migrant workers and employers know that illegal migration would not be tolerated anymore, the concerted threat of deportation sought to push both migrant workers and employers into complying with the new registration and legalisation requirements. With dual aim, the Malaysian government launched two enforcement exercises known as Ops Nyah I and Ops Nyah II (literally ‘operation riddance' I and II). While Ops Nyah I was designed to prevent unauthorised landings on Malaysia's long coastline, Ops Nyah II was directed at illegal migrants already in the country and took the form 
of raids at worksites and in squatter settlements. At the end of i992, after six months of a much proclaimed and publicised 'crackdown on illegal aliens', a total of 7I,000 illegal migrants had been detained and 2I,247 deported (New Sunday Times i4 February I993).

Although there was no doubt in official circles that illegal migrants had to 'be made to leave' or that Malaysia should be 'cleansed of illegal aliens', this first deportation exercise had its limitations. First, the deportation of thousands of illegal migrants, along with the fact that many went into hiding during the crackdown, had a direct, immediate effect on the national economy with labour shortages being reported in the construction, plantation, manufacturing and service sectors. This led employers' organisations to urge the government 'to relax its regulations concerning illegal foreign workers' (New Straits Times 29 August 1992). Second, since detention centres had a limited capacity and it was costly to hold illegal migrants in camps (about RM 3,50 per person per day), deportations were stepped up and detentions were implemented only periodically (New Straits Times ig August I992). Third, as many detained illegal migrants did not possess travel documents, the deportation procedures were very complicated and time-consuming (New Straits Times I9 October I992). Both a Malaysian immigration officer and a representative of the Indonesian embassy acknowledged in their interviews that, in order to ease and expedite deportations, 'extra-official practices' or 'back-door policies' were applied. For the Malaysian government, this meant deporting illegal migrants to the Thai border, regardless of their origin and without their being identified by any government (interview 6 October 2006, Putrajaya). For the Indonesian government, such practices included taking in deported migrants identified as Indonesians by the Malaysian government without further ado (interview 26 September 2006, Kuala Lumpur).

Table 3.5 Number of illegal migrants detained under Ops Nyah I and II

\begin{tabular}{lccc}
\hline Period & Ops Nyah I & Ops Nyah II & \\
\cline { 2 - 4 } & Total arrests & Total arrests & $\begin{array}{l}\text { Arrests per week } \\
\text { (per day) }\end{array}$ \\
\hline July-December 1992 & 20,453 & 19,268 & $963(138)$ \\
January-December 1993 & 14,211 & 41,584 & $799(114)$ \\
January-December 1994 & 11,082 & 43,189 & $830(118)$ \\
January-December 1995 & 7,825 & 32,835 & 631 (90) \\
\hline Total & 53,571 & 136,876 & 773 (110)
\end{tabular}

Source: Kassim (1996: 11)

Although the 'crackdown on illegal aliens' formally ended in December 
I992, Ops Nyah I and II continued. To illustrate, between December I99I and December I995, some 700-800 illegal migrants were arrested each week (see Table 3.5). Indonesians accounted for 99.8 per cent of those arrested entering the country illegally (under Ops Nyah I) and 70 per cent of those arrested within the country (under Ops Nyah II). The rest were from Bangladesh (13.2 per cent), Myanmar ( 9.5 per cent), Thailand (3.3 per cent), India (I.3 per cent) and Pakistan (I.2 per cent) (Kassim I996: I5). During this period, two new questions regarding detention and deportation policies were raised in newspapers: first, the detention of legal migrant workers and, second, the poor living conditions and abuses perpetrated in detention camps. Legal migrants had been detained because employers held their passports and, when the raids were carried out, had no documents to prove their legal status. In I993, the Immigration Department reported that II, oI 7 legal migrant workers had been detained and subsequently released at the request of their employers (New Straits Times I4 February I993). By I994, this number had risen to 35,312 (New Sunday Times I6 January I994).

In August 1995, Tenaganita published a report that denounced sustained physical and mental abuse in detention camps. This included the restriction of water to two glasses a day (while food was provided in plastic bags with holes so that they could not be used to collect rainwater), the housing of detainees in overcrowded blocks (up to 500 people per block) and the practice by which female detainees were given extra water and supplied with sanitary pads in exchange for sexual favours (see Tenaganita 1995). In 1997, Amnesty International reported that, in the five preceding years, 7I illegal migrants had died in detention camps. Of these, 59 died in Semenyih, the largest of the camps, allegedly of beriberi, a malnutrition-related disease. The Malaysian government denied the allegations, describing them as completely untrue and baseless. In I996, head of Tenaganita Irene Fernandez was charged under the Printing Presses and Publication Act I984 for maliciously publishing false information. After a trial that dragged on for seven and a half years, she was convicted in 2003 and sentenced to a twelve-month imprisonment (Malaysiakini II December 2003). In 2008, she was finally acquitted by the Criminal Division of the High Court of Malaysia in Kuala Lumpur.

Despite all the limitations and criticisms, a new deportation campaign was launched in January 1997 in the wake of the 1996 regularisation programme and accompanied by an amendment of the Immigration Act, which again raised costs for employers of illegal migrant workers. As in I992, the aim of this combination of a regularisation programme, a deportation campaign and increasing penalties for illegal migrants and their employers was to gain control over the migrant worker population. As one Malaysian newspaper stated, it was believed that these measures would counterbalance the fact that ' $a$ substantial and uncounted number of illegal 
immigrants was turning the role of the foreign worker from a temporary, controllable solution to a permanent, uncontrollable need' (New Straits Times 3 January 1997). This deportation campaign was announced as 'the biggest security sweep in Malaysian history, deploying more than 3,000 men including 1,000 soldiers, to conduct door-to-door checks at homes, offices and night markets and to seal off certain parts of the Thai-Malaysian border' (New Straits Times I January I997). In one highly publicised manoeuvre, an Indonesian navy vessel took about I,500 illegal workers back to Indonesia on three different occasions (January, July and August of the same year). In total, about 45,952 illegal migrants were detained in 1997 (Chin 2002: 29).

Despite these numbers, this deportation campaign also had limitations. According to Malaysian newspapers, the main problem this time was perceived in terms of costs and results. In particular, sustained criticism pointed to the fact that, while detention and deportation campaigns were very costly and time-consuming, the deportees could very easily return to Malaysia. For instance, according to the Deputy Home Minister, it cost between RM I25 and RM 400 to deport an immigrant to Indonesia (New Straits Times 7 January 1997). All in all, the government spent about RM I4 million in expelling some I3,I69 illegal migrants (New Straits Times 25 February 1997). Arrests, detention camps and deportation all amounted to some RM I,००o per illegal migrant worker (New Sunday Times 3I August I997). Nevertheless, it was generally perceived that illegal immigrants could very easily return to Malaysia. Indeed, the government admitted in May I997 that some 50,000 deported migrants were positioned along the Thai-Malaysian border waiting for their chance to re-enter Malaysia (New Straits Times I7 July I997).

\subsubsection{Repatriation campaigns}

With the financial crisis of 1997, the Malaysian government announced the repatriation of legal migrant workers in the hardest-hit construction and service sectors. In August I998, a total of I59,I35 legal migrant workers left the country upon expiry of their work permits. At the same time, I87,486 illegal migrants (many of them formerly legal) left the country under a programme for voluntary return ('amnesty' as it was called in Malaysia) that permitted illegal migrants to register and leave the country without penalty (Wong \& Anwar 2003: I8I). Moreover, that same year, 68,452 illegal migrants were detained, in comparison with 45,952 in I997. All in all, 415,073 migrant workers were sent back to their countries of origin in 1998 (Asia Migrant Centre 1999: 152). Again, as shown in section 3.5.3, in 200I, the Malaysian Parliament passed legislation that set a three-year limit to work permits for migrant workers. This meant the repatriation of those workers that had been in Malaysia for more than three years. In 2002 almost 400,000 migrant workers 
were sent back to their countries of origin in what became the biggest single repatriation exercise ever undertaken in Malaysia (Ford 2006: 228).

The number of migrants sent back to Indonesia in August and September 2002 far exceeded the capacity of return points in the transit provinces of Sumatra and Kalimantan. Notably, the sudden influx of deportees to Nunukan, a small island on Indonesia's border with the Malaysian state of Sabah, caused a humanitarian crisis that became a flashpoint in Indonesian-Malaysian bilateral relations. In the first half of August, between 5,000 and 9,000 people passed through Nunukan's immigration office every day (Palupi \& Yasser 2002: 2). Although the majority of those deported to Nunukan were moved to other areas of Indonesia, approximately 25,000 people remained in $2 \mathrm{I}$ camps run by registered recruitment agencies. According to local officials, at least half this number remained on the island without being registered (Palupi \& Yasser 2002: Io). NGO investigations have reported that between 67 and 70 deportees died (Palupi \& Yasser 2002: I7-I8). The effects on the population of Nunukan were also severe. Basic facilities were lacking as the town's infrastructure could not cope with the sudden quadrupling of its population. Moreover, although local residents profited in some ways by offering services and facilities for the deportees, prices for basic foodstuff shot up by Ioo per cent (Ford 2006: 239).

This mass repatriation campaign, together with the announcement of a temporary halt in the employment of Indonesian workers, and the politically motivated claim that they were to be replaced by workers of other nationalities, led labour activists and NGOs to protest outside the Malaysian embassy in Jakarta and to criticise the Malaysian government for its 'degrading' and 'disparaging' treatment of Indonesian workers. Some people called upon Indonesian workers to strike against deportation plans and condemned Malaysia for turning a blind eye to the immigrantsmuggling activities of its own nationals. In July 2002, a group of NGOs sent a letter to the Indonesian Coordinating Ministers for Politics and Security, Health and Welfare and Economics and Industry, as well as the Parliament and the National Human Rights Committee, to urge the government to address the impending mass repatriation. They asked their government to find a diplomatic solution that would put an end to the Malaysian government's arbitrary treatment of Indonesians, to prepare for future large-scale deportations, to instruct the local governments of sending areas to become involved and to undertake a complete revision of the process by means of which workers are sent and placed overseas (Ford 2006: 240).

Until 2002, illegal migration had been a relatively muted issue in the bilateral relations between Malaysia and Indonesia. However, this time the speaker of the Indonesian National Assembly criticised Malaysia in Parliament and called on the government to take action against 'the 
smaller country'. In an article titled 'Remember Konfrontasi', alluding to the past military confrontation between Malaysia and Indonesia (I962-1966), the Jakarta Post argued that Malaysia's new policies were far too extreme, recalling that 'there was a time, not so long ago, when Indonesia would not take such a belligerent act from a neighbouring country lying down' (I February 2002). The Malaysian government responded in feisty diplomatic terms, warning its citizens against travelling to Indonesia and calling upon the Indonesian government to take action against those who threatened to jeopardise bilateral relations with their protests (Liow 2004: 23). After a critical period in bilateral relations, the Nunukan crisis ended with new bills and projects to protect Indonesian workers abroad as well as new bilateral and multilateral negotiations. Significantly, the new Memorandum of Understanding (2004), which resulted from the negotiations between the two governments, aimed to regulate Indonesian labour migration to Malaysia, covering such issues as recruitment, medical check-ups and transportation, though without addressing the once touchy issues of deportation and repatriation of migrants.

\subsubsection{Voluntary return}

The mass repatriation campaign of 2002 once again brought to light the enormous difficulties and costs involved in detaining, holding and eventually deporting large numbers of migrants. Since then, illegal migrants have mainly been persuaded to return home. When launching the programmes for 'voluntary return' ('amnesties'), the Malaysian government proffered two main reasons. First and most important, voluntary return reduces costs of deportation. There was general consensus on the need to reduce deportation costs. The MTUC president stated that ' $[$...] the government can't keep on clamping down on illegals, stretching its resources to the limit. Don't forget, we are also feeding those in detention camps' (New Sunday Times 3I October 2004). Second, on some occasions, the Malaysian government presented these programmes for voluntary return as demonstrations of 'the Malaysian spirit of charity and forgiveness during the Muslim fasting month of Ramadan' (New Straits Times 23 October 2004). In general terms, these programmes have had significant results. For instance, official accounts indicated that in 2005 about 400,000 of an estimated 800,000-I,200,000 illegal migrants had returned under the 'amnesty' (New Straits Times 22 June 2005).

Although these results have been officially explained as a consequence of the increasing prosecution of illegal migrants in Malaysia, law and policy enforcement with regard to illegal migration has rather been lacking. In a rare official pronouncement on the matter, the Minister of Justice observed in 2002 that existing laws like the Immigration Act and the Penal Code gave adequate powers to authorities to deter the influx of ille- 
gal migrants, but that the 'lackadaisical attitude of some authorities in enforcing the laws was a cause for worry' (Business Times 5 February 2002). Indeed, a survey of too illegal migrants reveals that police harassment does not always result in detention since migrants can often bribe their way out of 'trouble' (see Wong \& Anwar 2003: 2I4). Despite this apparently widespread corruption, between I999 and 200I, only 2I police officers were charged with taking bribes (Star I3 March 2002). Lack of enforcement is also evident in the case of employers of illegal migrant workers. For instance, while in 2003 and 2004, a total of I2,319 illegal migrants was charged, during the same period only ro7 employers were charged with harbouring illegal migrants (New Sunday Times I5 August 2004).

Enforcement problems and pervasive corruption among officials raise the question of whether higher penalties and highly publicised prosecution campaigns adequately explain the huge response to the last programmes for voluntary return. Although this question would require a different kind of research, I should like to venture two possible explanations. First, Indonesian labour migration to Malaysia seems to be mainly temporary. As I noted in the introductory section of this chapter, many Indonesian migrants come to Malaysia in search of better wages and experience. After some years, many legal - but also illegal - migrants seem to return to their places of origin. In this context, an 'amnesty' for voluntary return might appeal since it would mean going back legally. Second, the geographic contiguity between Malaysia and Indonesia facilitates reentry into Malaysia. As illustrated by the cases presented by Wong and Anwar (2003), many illegal migrants return to Indonesia only to re-emigrate to Malaysia later on. In this regard, voluntary return does not mean leaving the country for once and for all. Since borders continue to be porous, programmes for voluntary return would seem to facilitate movement back and forth between countries.

\subsubsection{Criminalisation of illegal migrants}

While law enforcement has, in practice, remained rather low, it is also true that illegal migrants have been increasingly criminalised and prosecuted since 2000 . The message has been very clear: illegal migrants who did not voluntarily return to their countries of origin would face detention, prison, caning and deportation. More specifically, under the amended Immigration Act (2002), illegal migrants can be sentenced to mandatory jail terms for up to five years, receive up to six strokes of the cane and be fined up to RM I0,000. Moreover, Malaysians who employ illegal migrants can be jailed for three months and fined RM 5,000. Along with this tougher legislation, law enforcement measures against illegal migrants have intensified in recent years. Of particular importance is the fact 
that, since 2004, the People's Volunteer Corps (known as Ikatan Relawan Rakyat Malaysia, RELA), a paramilitary group, assists the police in arresting and detaining illegal migrants. The official justification for using RELA is lack of manpower in police and immigration departments: '[...] there are about 680 full-time enforcement officers compared with the 1.4 million strong legal foreign workers. Realising the shortage, the government has allowed Rela members to help out' (The Malay Mail ig February 2005).

RELA has received wide discretionary powers. These include the right to stop and question any person on the grounds of 'reasonable belief' that the person is a 'terrorist', 'undesirable person' or 'illegal migrant'; to arrest such persons; to enter and search premises without a warrant; and to carry arms, including batons and firearms. Moreover, in 2008, RELA took over management of the immigration detention centres. This new step towards complete outsourcing of migration control was once again justified in terms of a lack of public resources. RELA has now extended its control over the entire process, starting from arrest and detention through to the deportation of migrants. As a human rights' lawyer described it: 'Now RELA arrests them, RELA keeps them, RELA deports them' (interview 9 January 2008 , Bangi). This gradual privatisation of migration control has gone hand in hand with an increased number of arrests: while in $2004,23,57 \mathrm{I}$ migrants were arrested, in 2005, the figure rose to 28,079 and, in 2006, to 56,315 (Kassim 2008a: 22). Moreover, the participation of RELA members in detention campaigns has given rise to grave concerns among NGO and human rights organisations, which have denounced the abuses, torture and murder of several illegal migrants..$^{13}$

If migrant workers constitute a highly lucrative business opportunity for recruitment agencies, illegal migrants have become big business for RELA. If recruitment agencies earn money by recruiting and outsourcing migrant workers, RELA makes it by detaining and deporting them. The official argument for commercialising the detention and deportation of migrants has been 'to provide further motivation for them [RELA members] to do their best in flushing out unlawful migrants [...]. It signifies recognition of their unselfish service on behalf of the nation' (New Straits Times 26 October 2004). In 2006, the allowance was RM 80 'per head', i.e. for each detainee. As another human rights lawyer points out, this means rather more than mere pocket money for RELA when there are over two million migrants walking freely in the streets (Malaysiakini I5 March 2007). 'Two million migrants' refers to both legal and illegal migrants. In fact, many legal migrants continue to be arrested under these detention campaigns. According to RELA's director: 'The problem is we don't know which ones carry permits and which ones are illegal. In such a situation, should we be asking first who are the illegals? For sure there wouldn't be volunteers raising their hands' (Tempo 23-29 October 2007). This boils down to the fact that both legal and illegal migrants are prosecuted, detained and imprisoned. As 
the above-cited lawyer concludes: 'Nevermind whether he or she is documented or not - that's not their job. The special court at Semenyih has been set up precisely to decide on this. After all, nobody walks out of this special court without getting their backs whipped, prison-style' (Malaysiakini I5 March 2007).

In general terms, we can conclude that detention and deportation campaigns have been key measures in the regulation of illegal migration in Malaysia. Unlike most Western countries, these measures have mainly been implemented inside national territory rather than at the border. For instance, from I 992 to 2006 , of the total one million arrested migrants, I2.3 per cent occurred at the border and 85.9 per cent within the country (Kassim 2008a: 2I; see also Table 3.5). Also notable is the fact that deportation campaigns have not been implemented on any continuous basis since they are too costly and time-consuming. Detention and deportation have been resorted to in periods of economic crisis, when the demand for both legal and illegal migrants drops, or in times of social unrest, as a way of demonstrating state control over the national territory and boundaries. We might then conclude that deportation campaigns have sought to reinforce the core principle of Malaysian labour migration policies: the temporality and malleability of migrant workers. Yet there is a significant difference. While all legal migrants may be required to leave at any particular time, not all illegal migrants are deported. As I have just noted, public resources are limited and arrest and removal may be avoided by paying a bribe, while the border can always be re-crossed. Hence, if we focus on policy effects rather than declarations and discourse, deportation policies seem to function more as a measure to reinforce the illusion of control rather than as one that actually controls migration.

\subsection{Final remarks}

Malaysia has long depended on migrant labour. Anyone visiting Malaysia from the I880 onwards would be struck by the presence of migrant workers in the country. At the end of the nineteenth and beginning of the twentieth centuries, a visitor could observe Chinese workers in tin mines and Indian workers at sugar, coffee and, later, rubber plantations. Indian workers also constructed roads and railways and were employed in the associated public services. A hundred years later, from the ig80s onwards, a visitor would again find many migrant workers. This time they mainly come from Indonesia, but also Nepal, India, Myanmar, Vietnam and Bangladesh. As in the past, they work in plantations and construction sites as well as in the manufacturing and service sectors. In response to the first question of my research - how did the Malaysian state respond to this demand for migrant labour - the present chapter gives a clear answer. 
Since the early I990s, it has resorted to a guestworker programme.

As with any guestworker programme, Malaysian migration policies have sought to open up entry while restricting membership. On the one hand, this means that several hundred thousand migrant workers enter the country every year. Any attempt of the Malaysian government to reduce this number has been opposed by employers and finally reversed. Although Malaysian scholars have interpreted these changes as the best illustration of the ad hoc, stop-go character of Malaysian migration policies, a more general perspective allows us to observe how, in fact, entry has never been really restricted. Since economic growth has depended on cheap, flexible labour, there was general consensus on the 'need' for migrant workers. On the other hand, restriction has been applied within the country. Migration policies have aimed to turn migrants into pure labourthat is, a force that could be immobilised within the labour market and returned when no longer needed, which is to say in periods of economic downturn, in case of illness or pregnancy or before migrants could settle in the country. As many of my interviewees put it: 'Malaysia doesn't have migrants, just foreign workers.'

This guestworker policy has required setting up and maintaining a permanent apparatus to deal with the recruitment, transport, control and return of migrant workers. Since this machinery could not be provided by the Malaysian state, the labour system in its entirety has functioned on the basis of private agencies. These include agencies that recruit migrant workers in their countries of origin; ones that process their papers, bring them to Malaysia and, in recent years, outsource their labour on the labour market; and ones that regularise illegal migrants. Finally, a paramilitary group acts as a private agency to detain, imprison and deport illegal migrants. This commercialisation and privatisation of the entire labour migration processing, control and riddance system has been perceived as necessary to fill in those administrative gaps the Malaysian state could not cover. However, it has also driven up the costs of legal migration and made the whole migration process even more opaque and uncertain. For instance, the presence of recruitment agencies has tended to make legal entry more expensive, while also blurring the legal contours of employers' responsibility vis-à-vis migrant workers. The privatisation of detention and deportation campaigns, in the hands of RELA, has meant more detentions and more human rights violations.

As for the second question of this research - what the case of Malaysia tells us about the relationship between markets, citizenship and rights the first thing to highlight is the market factor's central role. This needs to be explained not only in terms of employers' capacity to impose their demands, but also the crucial factor that economic growth - based on the import of cheap foreign labour - has been part and parcel of the social engineering programme of the new nation-state. However, it is no less 
true that the borders and boundaries of the Malaysian nation-state have gradually closed to the outside world. While geographic borders have certainly remained open to as many migrant workers as demanded by markets, severe restrictions have been imposed on membership. The boundaries between citizens and non-citizens have become increasingly impenetrable, at least in Peninsular Malaysia. Eastern Malaysia is another story. While, in the past, ethnicity was an important component of migration policies and their implementation, since the I990s, citizenship has become an uncontested barrier. As argued in section 3.4, this is the fruit of demands to protect the national labour market (particularly, the socio-economic position of Malays) and of an increasing emphasis on alleged migration-related security issues.

Rights, then, have played quite a marginal role in the formulation and implementation of migration policies. First, as we have seen, migrant workers have no right to permanent residence or family reunification, are dependent on their employers for their work permits and are made to leave the country whenever the state decrees. Second, migrants are detained and deported with very little accountability, while human rights violations tend to be the norm during detention and deportation campaigns. These abuses of migrants' rights (by law and in practice) have not been notably contested by the legal and political system. On the contrary, when denounced by the few Malaysian NGOs that work for the defence of migrants' rights, laws such as the Internal Security Act and the Printing Presses and Publication Act have been deployed to prosecute and silence controversial voices. Although the disproportionate power of the Malaysian executive has made it possible to take the philosophy of guestworker programmes to extremes, it has not completely succeeded in turning migrants into pure labour or, as commonly said in Malaysia, "just foreign workers'. While the courts and other social and political actors did not contest the limitations imposed on migrant rights, the official practice has been challenged by migrants themselves who consciously opt for illegality.

As we have seen, illegal entry often represents a faster, cheaper way of migrating to Malaysia. Once in the country, illegal migrants are not tied to employers, which means they can move more freely from job to job, their work is not taxed and neither is their stay in Malaysia necessarily determined by state-imposed time limits. In short, illegality can be a tempting way of getting round the restrictions imposed on Malaysian 'foreign workers' (Garcés-Mascareñas 2008b). In this regard, as signalled by Wong and Anwar (2003: 2I7-2I8), striking similarities appear when Chinese migration from former times is compared with current illegal migration to Malaysia. First, Chinese labour migration to colonial Malaya is comparable to illegal migration in its speculative yet spontaneous character. In both cases, most migrants paid their own passage to Malaysia 
and the migrant experience was organised on the basis of their own social networks. Second, and partially as a consequence of this, both former and current illegal migrants were mainly recruited within the country by local employers. As in the case of the illegal, old Chinese migrants presented a higher rate of job mobility and higher wages than Indian workers, whose migration to Malaya was planned and directed by the colonial authorities.

However, as I have observed elsewhere (Garcés-Mascareñas 2008a: I22), there is one major difference. While old Chinese migration was unregulated but not illegal, in recent decades, 'unregulated' has become synonymous with 'illegal'. This leads to another difference: in contrast with the past, those who migrate or have fallen outside the regulated migrant system face detention and deportation. This does not mean that illegal migrants are necessarily removed from the country because deportation can be dealt with by paying a bribe or by re-crossing the borders. It does mean, however, that non-regularity turns migrants into 'detainable', 'imprisonable' and 'deportable' subjects. They are reduced to living objects that can be deported or killed without trial or protest. While escaping direct state control, illegal migrants thus enter a grey zone where state control can still be imposed (albeit as a more remote possibility) in a heightened expression: the deprivation of free movement and threat of forced physical expulsion. In this grey zone, illegal migrants become subjects beyond the law. It is precisely their a-legality that makes 'extra-official practices' or 'back-door policies' possible. After all, the state cannot be held accountable for what is thrust beyond the pale of legal existence. 


\section{Spain}

\subsection{Introduction}

One of the most frequently cited factors for explaining migration flows is the economic difference found between countries of origin and destination. This is precisely what in I992 Spain's then Prime Minister Felipe González noted when showing fellow European heads of state a photograph of Morocco taken from Spanish shores: 'This is our Rio Grande [...]. It is not far. And living standards are four, five, ten times lower on the other side' (The New York Times 26 October I992). Ever since, Spain's economic growth and the progressive impoverishment of Morocco and Africa, in general, have only aggravated the difference. According to the 2007/2008 UN Human Development Report, the border between Spain and Africa had come to represent the highest development gap in the world: while Spain ranks thirteenth in the UN Human Development Index ${ }^{\mathrm{I}}$ (with an HDI of 0.949), Morocco comes in at number I26 (0.646), Senegal at 156 (0.499) and Mali at I73 (0.38). In terms of strict economic differential measured in gross domestic product (GDP) per capita and purchasing power parity - the wealth gap between Spain (with a GDP per capita of \$US 27,I69) and Morocco (\$US 4,555), Senegal (US\$ I,792) or Mali (\$US $\mathrm{I}, 033)$ is much greater than that between the United States (\$US 4I,890) and Mexico (\$US I0,75I) (UN Human Development Report 2007/2008: 229-232).

Although the economic gap between Spain and Latin America or Spain and Eastern European countries is smaller, the difference is no less relevant when it comes to explaining migratory flows to Spain. In the case of Latin America, the inflow of immigrants seeking work began to take on significant proportions in the I990s and continued to grow exponentially after 2000 as the result of economic crises in countries like Ecuador, Argentina, Bolivia and Peru. Besides the general economic downturn, the crisis generated greater economic and social inequality. Their rapid impoverishment compelled members of the middle class to begin emigrating to Spain. As for Eastern Europe, it is essential to bear in mind how the fall of the Berlin Wall in I989 and ensuing economic restructuring impacted emigration. For 2007-2008, the per capita GDP in Spain (\$US 27,I69) was three times higher than in Romania (\$US 9,060) and four times more 
than in the Ukraine (\$US 6,848) (UN Human Development Report 2007/2008: 229-232). While these economic differences have endured, the frontier of the European Union - and along with it, though not immediately, its common labour market - has been extending eastwards to include most of the Eastern European countries.

To these economic differences, one must also add the large-scale economic growth that occurred in Spain after the I990s and the need, as we shall see in the following section, to cover increasing labour shortages. This, along with an oversized informal economy, which was estimated to account for 22 per cent of GDP (Schneider 2004: 5I), is what, for many scholars, has functioned as the motor or 'pull effect' of immigration flows. As Solanes points out regarding illegal migration, '[...] people often lose sight of the perception, which to my mind is indisputable, that the real pull effect on candidates for clandestine or illegal immigration is the certainty that they are soon going to find work in the black economy. [...] Clandestine or illegal immigrants know that their salary will be less than that of foreigners in a regular situation and that of the country's citizens, and also know that they are going to have to face harsh living and work conditions, but they do have the conviction that they are going to be employed and paid, and it is this certainty that spurs them on' (Solanes 2003: I3-I4; emphasis mine).

Geographic and cultural proximity has also determined the nature of migratory flows into Spain. On the one hand, Morocco is only fourteen kilometres away. Besides this geographic proximity, the northern part of Morocco was a Spanish colony from I9I2 to I956. The still Spanish enclaves of Ceuta and Melilla testify to this. Besides this common history, which can be traced back over centuries, the Spanish influence in this area still makes itself felt through the media, tourism and commercial activities. On the other hand, South America, although it is farther away in geographical terms, is frequently felt to be much nearer. This perceived closeness derives from centuries of Spanish colonialism, a history of Spanish mass emigration to South America at the beginning of the twentieth century and again after the Spanish Civil War (I936-I939) and, more generally, from similarities regarding religion, culture and language. For all these reasons, Spain has become one of the main destination countries for Latin American migrants. For all these reasons, too, requirement of an entry visa for citizens of these countries was much more difficult to introduce.

Finally, social networks feed and define the geographies of migration. First of all, old migrants might bring new migrants by informing and assisting them when it comes to entry, work, housing and other necessities. Second, migrants are allowed to send for their families after one year of legal residence. While in 2000 , only seven applications for family reunification were authorised, in 2004 and 2007 , this number grew to 
I03,998 and I28,I6I, respectively (El País 29 March 2005; 8 December 2008). The fact that, in 2007,8 I.2 per cent of immigrants with relatives in their countries of origin declared their intention to bring them to Spain (INE 2008: 6) leads one to conclude that immigration for family reasons will continue to grow in the coming years. In more general terms, as in the cases of most Western European countries from the I970s onwards, this means that migration flows to Spain may continue to take place independently from labour demands.

While all these factors explain migration flows, the question once again is how the Spanish state actually regulated them and, more specifically, how it responded to market demands for migrant labour. More precisely, to what extent were these demands answered? To what extent were migrant workers allowed to enter into the country and under what conditions? What were the main effects of this policy? And where did the border between authorised and unauthorised migrants lie? From a more theoretical perspective, the question is to what extent and how the trilemma between markets, citizenship and rights has been solved-or to what extent attempts have been made to solve it - both by law and in practice. These questions, at the core of my research, are considered in this chapter. This is done by giving, first, an overview of the demand for migrant workers and the consequent migration flows (section 4.2). Next, the main developments in terms of migration policies are briefly described (section 4.3). As in the chapter on Malaysia, this is done from a historical perspective, for the past becomes essential to understand the present. The following four sections analyse the formulation, implementation and effects of entry policies (section 4.4), stay policies (section 4.5), regularisation programmes (section 4.6) and deportation campaigns (section 4.7). In the closing section of this chapter (section 4.8), some preliminary answers are sketched out.

\subsection{From emigration to immigration}

\subsubsection{Country of emigration}

The nineteenth century was a mobile age. In Western Europe rapid population increase, industrialisation and urban growth led to an expansion of migration systems. As the century advanced, many internal migrations tended to become permanent and more people migrated across international borders, if not across the Atlantic. By the end of the nineteenth century, Europeans travelled farther and were more likely to stay away (Moch 2003: I58). In Spain, despite a process of economic modernisation (Prados de la Escosura 2003), a high percentage of the population continued to be employed in agriculture, and permanent internal migration rates remained low. To explain the slow growth rate in permanent internal 
migration, scholars have stressed low demographic dynamism and agricultural backwardness (Nadal i975; Tortella i987), cultural factors such as conservatism, resistance to mobility and the desire for land ownership (Sánchez-Albornoz I977; Tortella I994; Carmona \& Simpson 2003) as well as low levels of industrialisation and urban development (Nadal I975; Sánchez-Albornoz I977; Tortella I987). The counterpart was the persistence of short-distance temporary migration (Silvestre 2007).

Although it pioneered migration to the Americas with an estimated 250,000 emigrants in the sixteenth century (Sánchez Albernoz I988: I4), Spain would come to lag behind other countries in the nineteenth-century European mass migration. In this period, most European migrants to the Americas came from England, Germany, northern Italy and, later on, Scandinavia. However, when Spanish mass migration to the Americas finally took off at the beginning of the twentieth century, it grew considerably more than in other Southern European countries. For instance, between I900 and I9I3, the growth rate of Spanish emigration was almost I2 per cent, compared to 4.7 per cent for Italy and 9.9 per cent for Portugal

Table 4.1 Spanish migration to the Americas, 1882-1930

\begin{tabular}{lc|cc|rc}
\hline Year & $\begin{array}{l}\text { Migration } \\
\text { balance }\end{array}$ & \multicolumn{1}{l}{ Year } & $\begin{array}{l}\text { Migration } \\
\text { balance }\end{array}$ & \multicolumn{1}{l}{ Year } & $\begin{array}{l}\text { Migration } \\
\text { balance }\end{array}$ \\
\hline 1882 & 13,286 & 1899 & $-62,722$ & 1916 & 3,806 \\
1883 & 3,901 & 1900 & 5,638 & 1917 & $-5,164$ \\
1884 & 4,839 & 1901 & 3,843 & 1918 & $-14,877$ \\
1885 & 596 & 1902 & $-6,630$ & 1919 & 19,933 \\
1886 & 4,589 & 1903 & 2,572 & 1920 & 87,214 \\
1887 & 14,152 & 1904 & 30,144 & 1921 & $-31,973$ \\
1888 & 23,554 & 1905 & 64,030 & 1922 & 7,316 \\
1889 & 72,404 & 1906 & 52,863 & 1923 & 54,218 \\
1890 & 11,064 & 1907 & 51,288 & 1924 & 44,821 \\
1891 & 5,180 & 1908 & 71,362 & 1925 & 17,824 \\
1892 & 8,258 & 1909 & 50,675 & 1926 & 922 \\
1893 & 19,833 & 1910 & 91,922 & 1927 & 1,186 \\
1894 & 14,691 & 1911 & 70,512 & 1928 & 11,908 \\
1895 & 64,472 & 1912 & 133,994 & 1929 & 20,076 \\
1896 & 98,864 & 1913 & 72,653 & 1930 & 2,154 \\
1897 & $-9,156$ & 1914 & $-62,481$ & Total & $1,042,775$ \\
1898 & $-77,695$ & 1915 & $-19,084$ & & \\
\hline
\end{tabular}

Source: Sánchez Albornoz (1988: 20) 
(Sánchez Alonso I995: I35). In I9I2, the figure for Spain's migration balance to the Americas was I33,994 (see Table 4.I). In total, according to South American sources, from I880 to I930 about 3.5 million Spaniards migrated to South America (Sánchez Albornoz I988: I8).

To explain the growth of Spanish emigration in the early I900s, scholars distinguish between push and pull factors. One push factor often cited is a crisis in the agricultural sector that was triggered by the arrival of agricultural products (notably, cereals) from the Americas and the appreciation of Spanish currency (Sánchez Alonso I995). Although poverty has often been mentioned as a way of explaining Spanish emigration to South America, this should be nuanced: emigration was not an option for all would-be migrants, but mainly those who were relatively skilled and came from the least economically 'backward' regions (Mascareñas I986; Sánchez Alonso I995; Moya I998). This has led some scholars to point out that pull factors were even more important than push factors. Economic activity and growth in destination countries (Sánchez Alonso I995), along with wage differentials (Hatton \& Williamson I994), would seem to be critical in explaining Spanish emigration to South America and particularly to countries such as Argentina, Brazil, Cuba and Uruguay.

World War I put an end to Spanish emigration to countries that had hitherto been traditional destinations. Instead, many Spanish workers migrated to France in response to labour demands produced by the war and post-war economies. This migration declined in the second half of the I920s due to economic recession in France. Moreover, Spain's neutrality in World War I put the country in the role of international goods supplier, which gave rise to an increase of internal labour demands. While 6I per cent of all Spanish migrants went abroad in the period of I9OI-I9IO, the figure was only 6 per cent for the period of I92I-I930 (Bover \& Velilla I999: 6). However, the Spanish Civil War (from I936 to I939) brought about a new trend in outwards migration. Now, Spanish emigration was arising from political rather than economic reasons. In March I939, the 'Valière report', commissioned by the French government, estimated some 440,000 Spanish refugees living in France. In I945, the number of permanent Spanish exiles was estimated to be 220,000 ,

Table 4.2 Intercontinental and continental Spanish emigration, 1950-1975

\begin{tabular}{llll}
\hline Destination & $1950-1959$ & $1960-1969$ & $1970-1975$ \\
\hline Total (thousands) & 550 & 810 & 473 \\
Intercontinental (\%) & $80-90$ & 26 & 9 \\
Continental (\%) & 20 & 74 & 91 \\
\hline
\end{tabular}

Source: Venturini (2004: 16) 
mainly in France (I25,000), Mexico (28,000), Algeria $(\mathrm{I} 7,000)$ and other Latin American countries (Vernant I953: 59).

After the Civil War, World War II and the post-war period, the growing importance of the manufacturing sector and increased agricultural mechanisation radically modified the structure of employment. Spain went from being a largely agricultural nation to a modern industrial one. During the I950s alone, a million workers left agriculture (Bover \& Velilla I999: 7) and, between I960 and I985, the percentage of the Spanish population employed in agriculture fell from over 38 per cent to I8 per cent (Jimeno \& Toharia I994: 7). These changes once again led to an intensification of Spanish labour migration both abroad and inside Spain. While, in the I950s, most Spanish emigrants left for South America, in the I96os, the majority moved to Western Europe, responding to the labour shortages that resulted from post-war reconstruction efforts (see Table 4.2). Over the I960s and early I970s, it is estimated that more than I0०,000 Spanish workers emigrated to Western Europe per year. While in I960 around 6r per cent emigrated to France, I8 per cent to Germany and I per cent to Switzerland, the figures for I970 were 25 per cent to France, 39 per cent to Germany and 25 per cent to Switzerland (see Table 4.3).

Table 4.3 Emigrations flows from Spain to the main destination countries, 1960-85

\begin{tabular}{lcccc}
\hline Year & Total (absolute) & France (\%) & Germany (\%) & Switzerland (\%) \\
\hline 1960 & 49,610 & 61 & 18 & 1 \\
1965 & 80,916 & 45 & 25 & 10 \\
1970 & 102,079 & 25 & 39 & 25 \\
1975 & 22,656 & 17 & 1 & 72 \\
1980 & 14,252 & 3 & 0 & 92 \\
1985 & 17,382 & 4 & 0 & 75 \\
\hline
\end{tabular}

Source: Venturini (2004: 17)

Parallel to Spanish emigration to Western Europe, in the period I960-I973 internal migration intensified from poor rural areas such as Andalusia, Castile-León, Castile-La Mancha and Extremadura to richer industrial towns in regions such as Catalonia, Madrid and the Basque Country. By I970, for instance, 38 per cent of the population in Catalonia was born elsewhere, and this figure increased up to 47 per cent in the metropolitan area of Barcelona (Woolard i986:56). At that time, people born 'elsewhere' in the country were seen as 'immigrants' or as 'others' and, as such, worked in those jobs rejected by locals. This massive influx of cheap labour into Spanish industrial centres was crucial for the country's economic development. However, by the late I970s and early i980s, following economic 
decline, there was a considerable decrease in inter-regional migration in Spain. Bentolila and Blanchard (I990: 240) argue that this decrease cannot be explained in terms of reductions in differentials across regions, but by a rise in unemployment overall.

\subsubsection{Unexpected immigration}

In the mid-I980s, Spain unexpectedly (Izquierdo I996) went from being a country of emigration to having a positive balance in migratory flow. The question that arises from this, as Cachón (2002b) suggests, is not only how this change occurred, but also why it did not happen earlier. As Cachón indicates, historic ties with Morocco and Latin America, geographic and cultural proximity, or economic inequality between the countries (in terms of both economic growth and wages) could have, much earlier, triggered significant inwards migratory flows. So why now and not before? Faced with this conundrum, many authors coincide, signalling that what made Spain a country of immigration in the mid-I980s were changes that had come about in Spain (rather than in countries of origin), particularly on the labour market (King, Fielding \& Black I997:I0; Cachón 2002a: III; Oliver Alonso 2005: 8; Calavita 2005: 52).

With regard to Southern Europe as a whole, King, Fielding and Black (I997: I0) suggest the coexistence of sectors of high and low productivity as the prime explanatory factor for this so-called 'unexpected immigration'. These differences in productivity would not only correspond to the binomial of rural-agricultural versus urban-industrial, but also coexist in a single economic sector with, for example, small family farms alongside big agricultural enterprises, or low-cost auxiliary services in urban areas with major concentrations of income. These sectors of lower productivity, characterised by high levels of informal economic activities, would require a cheap and flexible labour force. While in the I960s and I970s, this demand was covered by internal rural-urban immigration, by the mid-I980s it was starting to be met by immigrants from outside the country.

This brings us to the second explanatory factor postulated by King et al. (I997: I0): the transfer of native workers from low-productivity sectors to high-productivity sectors and the resulting need for migrant workers in the former. Along the same lines, Cachón (2002 b: I2) suggests that the main factor triggering the immigratory phenomenon was the growing imbalance between an autochthonous labour force that had slowly been raising its 'job acceptability level' and the demand for workers in sectors or branches of activity that local workers were less and less inclined to accept. This higher level of job acceptability among the autochthonous population is related to the entry of Spain into the European Community, economic growth during the period of I986 to I992, the development of the welfare state, the improved education level of the economically active 
population, the maintenance of family networks and the rapid rise in social expectations (ibid.: 2).

After the I990s, this imbalance on the labour market was further aggravated by two factors related to labour supply and demand. First, economic growth from 1995 to 2001 entailed an increased demand for labour involving almost 670,000 new jobs per year (Oliver Alonso 2007: 46). Second, with entry into the job market by the cohorts of those born after I976 (notably, the non-entry of those who were not born after this date because of the sharp decline in birth-rate), the offering of new native workers declined after I992 by approximately two million people - the equivalent of I60,000 fewer workers each year (ibid.: 35). Although the high unemployment rates (22 per cent in I996) and low levels of female participation (48.3 per cent of the female working-age population in I996) made it possible to mobilise growing contingents of native workers (ibid.: 50), I9.I per cent of the total new employment generated in Spain over the period of 1996 to 2000 was absorbed by immigrants. In the zones with the highest concentrations of immigration (the Mediterranean coast, Madrid, La Rioja and the Canary Islands), this figure rose to 23.2 per cent while, in areas with a smaller presence of immigrants, it was I3.6 per cent (Andalusia, Castile-La Mancha, Aragon and Navarra) and Io.9 per cent (North and North-East) (ibid.: 55).

As a result of these transformations, between I985 and 2000, the number of legal foreign residents in Spain went from 250,000 (0.75 per cent of the total population) to almost 900,000 (2.I8 per cent) (Ministerio del Interior 2000: 25). While, at the beginning of the I980s, the immigrant population in Spain was principally European (65 per cent), by 2000 , the majority (6o per cent) came from non-European countries (see Table 4.4). This change has been dubbed the 'Third Worldization' of immigration (Casey I998: I2). In 2000, the majority collectives were Moroccans (22 per cent), followed by British (20.I per cent), Germans (8.2 per cent), French (4.7 per cent), Portuguese (4.6 per cent), Ecuadorians (3.4 per cent), Italians (3.4 per cent) and Chinese (3.2 per cent) (Ministerio del Interior: 213). Cachón (2002a: I04) points out that, compared with that of the early I980s, the kind of immigration coming to Spain in this period was 'new' in a number of senses: in zones of origin and their levels of development (Morocco, Eastern European and Asian countries), in culture and religion (i.e. non-Christian), in phenotypical features (Arab, African and Asian), in terms of individuals (53.2 per cent men and 45 per cent women) and, in particular, in being economic immigrants who came to Spain to work.

In general terms, non-European immigrant workers occupied jobs that were shunned by local workers. In I995, 70.8 per cent of migrant workers with a work permit were concentrated in the sectors of domestic service (26.6 per cent), hotel and catering (I3.4 per cent), retail trade (9.4 per cent) 
Table 4.4 Foreign residents in Spain in absolute numbers, 1975-2001

\begin{tabular}{llllllll}
\hline Years & EU & $\begin{array}{l}\text { Rest of } \\
\text { Europe }\end{array}$ & $\begin{array}{l}\text { North } \\
\text { America }\end{array}$ & $\begin{array}{l}\text { Latin } \\
\text { America }\end{array}$ & Africa & Asia & Total \\
\hline 1975 & 92,917 & 9,785 & 12,361 & 35,781 & 3,232 & 9,393 & 165,289 \\
1980 & 106,738 & 11,634 & 12,363 & 34,338 & 4,067 & 11,419 & 182,045 \\
1985 & 142,346 & 15,780 & 15,406 & 38,671 & 8,529 & 19,451 & 241,971 \\
1990 & $N A^{*}$ & NA* & 21,186 & 59,372 & 25,854 & 29,116 & 407,647 \\
1995 & 235,858 & 19,844 & 19,992 & 88,940 & 95,718 & 38,352 & 499,773 \\
$2001_{* *}^{*}$ & 331,352 & 81,170 & 15,020 & 282,778 & 304,109 & 91,552 & $1,109,060$ \\
\hline
\end{tabular}

* Europeans were not included due to measuring system changes.

** From 2001, EU data include countries from the European Economic Area (EEA).

Source: Moreno Fuentes (2005: 9)

and construction (9.2 per cent) (Cachón I997: 56-57). To this pattern of sectorial concentration, one must add specialisations according to geographic origin: while Moroccans and people from other parts of Africa represented 95 per cent of the foreigners working in agriculture and 78 per cent of those working in construction (70 per cent of whom were from Morocco); women from the Philippines and the Dominican Republic were the most numerous in domestic service; and Moroccans, Latin Americans and Chinese worked in the hotel and catering sector (ibid.: 57).

\subsubsection{Consolidation as a country of immigration}

Although immigration in Spain started to increase in the I990s, it was only after 2000 that it began acquiring major dimensions. This unprecedented growth was once again related to conditions in Spain and, more specifically, to a worsening of the aforementioned imbalance between labour's supply and demand. Between $200 \mathrm{I}$ and 2005 , the growth of the Spanish economy led to an increase of 690,000 new jobs per year (compared with 670,000 between I995 and 200I). The annual average for 2006 gives a figure of 19.6 million jobs for total employment in Spain, which represents a gain of 6.4 million jobs (46 per cent more) since I997. In comparative terms, this means that, while Spain represented 8 per cent of total employment for the European Union, between 2000 and 2005, it generated almost 40 per cent of new jobs (Oliver Alonso 2007: 46). And yet, the capacity for attending to this demand was reduced with regard to the previous period due to the drop in unemployment figures (7.I per cent in 2005), an increase in employment activity rate (among females measured at 58.I per cent in 2005) and the demographic shock due to the decline in birth-rate after I976 (Oliver Alonso 2005: 32). 
This imbalance between labour supply and demand was once again solved by the entry of immigrants, who absorbed 53 per cent of the new jobs generated in Spain between 200I and 2005 (Oliver Alonso 2007: 50-55). In zones with more immigration (the Mediterranean coast, Madrid, La Rioja and the Canary Islands), this figure was as high as 65.7 per cent while, in areas with fewer immigrants, it was 33.9 per cent (Andalusia, Castile-La Mancha, Aragon and Navarra) and 37.4 per cent (North and North-East). In absolute terms, immigration figures rose to almost 900,000 foreign residents (2.I8 per cent of the total population) in 2000 , I. 3 million (3.IO per cent) in 2002, I.9 million (4.48 per cent) in 2004, 3 million (6.7 per cent) in 2006 and 3.9 million (almost Io per cent) in 2007 (see Table 4.5).

Table 4.5 Foreign residents in Spain in absolute numbers and row percentages, 2001-2007 (on 31 December)

\begin{tabular}{|c|c|c|c|c|c|c|c|}
\hline Years & EU* & $\begin{array}{l}\text { Rest of } \\
\text { Europe }\end{array}$ & $\begin{array}{l}\text { North } \\
\text { America }\end{array}$ & $\begin{array}{l}\text { Latin } \\
\text { America }\end{array}$ & Africa & Asia & Total \\
\hline 2001 & $\begin{array}{l}331,352 \\
29 \%\end{array}$ & $\begin{array}{l}81,170 \\
7 \%\end{array}$ & $\begin{array}{l}15,020 \\
1 \%\end{array}$ & $\begin{array}{l}282,778 \\
25 \%\end{array}$ & $\begin{array}{l}304,109 \\
27 \%\end{array}$ & $\begin{array}{l}91,552 \\
8 \%\end{array}$ & $\begin{array}{l}1,109,060 \\
100 \%\end{array}$ \\
\hline 2002 & $\begin{array}{l}362,858 \\
27 \%\end{array}$ & $\begin{array}{l}107,574 \\
8 \%\end{array}$ & $\begin{array}{l}15,774 \\
1,1 \%\end{array}$ & $\begin{array}{l}364,569 \\
27 \%\end{array}$ & $\begin{array}{l}366,518 \\
27 \%\end{array}$ & $\begin{array}{l}104,665 \\
7 \%\end{array}$ & $\begin{array}{l}1,324,001 \\
100 \%\end{array}$ \\
\hline 2003 & $\begin{array}{l}406,199 \\
24 \%\end{array}$ & $\begin{array}{l}154,001 \\
9 \%\end{array}$ & $\begin{array}{l}16,163 \\
0,9 \%\end{array}$ & $\begin{array}{l}514,484 \\
31 \%\end{array}$ & $\begin{array}{l}432,662 \\
26 \%\end{array}$ & $\begin{array}{l}121,455 \\
7 \%\end{array}$ & $\begin{array}{l}1,647,011 \\
100 \%\end{array}$ \\
\hline 2004 & $\begin{array}{l}498,875 \\
25 \%\end{array}$ & $\begin{array}{l}168,900 \\
8 \%\end{array}$ & $\begin{array}{l}16,964 \\
0,8 \%\end{array}$ & $\begin{array}{l}649,122 \\
32 \%\end{array}$ & $\begin{array}{l}498,507 \\
25 \%\end{array}$ & $\begin{array}{l}142,762 \\
7 \%\end{array}$ & $\begin{array}{l}1,977,291 \\
100 \%\end{array}$ \\
\hline 2005 & $\begin{array}{l}569,284 \\
20 \%\end{array}$ & $\begin{array}{l}337,177 \\
12 \%\end{array}$ & $\begin{array}{l}17,052 \\
0.6\end{array}$ & $\begin{array}{l}986,178 \\
36 \%\end{array}$ & $\begin{array}{l}649,251 \\
23 \%\end{array}$ & $\begin{array}{l}177,423 \\
6 \%\end{array}$ & $\begin{array}{l}2,738,932 \\
100 \%\end{array}$ \\
\hline 2006 & $\begin{array}{l}661,004 \\
21 \%\end{array}$ & $\begin{array}{l}367,674 \\
12 \%\end{array}$ & $\begin{array}{l}18,109 \\
0,6 \%\end{array}$ & $\begin{array}{l}1,064,916 \\
35 \%\end{array}$ & $\begin{array}{l}709,174 \\
23 \%\end{array}$ & $\begin{array}{l}197,965 \\
6 \%\end{array}$ & $\begin{array}{l}3,021,808 \\
100 \%\end{array}$ \\
\hline 2007 & $\begin{array}{l}1,546,309 \\
38 \%\end{array}$ & $\begin{array}{l}114,936 \\
2 \%\end{array}$ & $\begin{array}{l}19,256 \\
0,4 \%\end{array}$ & $\begin{array}{l}1,215,351 \\
30 \%\end{array}$ & $\begin{array}{l}841,211 \\
21 \%\end{array}$ & $\begin{array}{l}236,770 \\
6 \%\end{array}$ & $\begin{array}{l}3,979.014 \\
100 \%\end{array}$ \\
\hline
\end{tabular}

* EU data include countries from the EEA, which expanded over the years.

Source: Ministerio del Interior (2001: 224, 2002: 479, 2003: 51, 2004: 289-290, 2005:

275-276, 2006: 111-112; 2007: 33-34)

If the figures are taken by continents (see Table 4.5), the increase of foreign residents from European countries between $200 \mathrm{I}$ and 2007 is noteworthy. This is principally due to the greater numbers of immigrants coming in from the countries of Eastern Europe, which are gradually joining the Community. ${ }^{2}$ In these years, one also observes growth in the Latin American community (over 300 per cent), which now represents one third of Spain's immigrant population. Although immigration from Africa and Asia also increased in this period (I76 per cent and I59 per cent more, 
respectively), it lost relative presence due to the advance of immigration from Europe and Latin America. If we observe the distribution by nationalities (see figure in Annex 5), it is important to indicate how EU-I5 countries (specifically the UK, Germany, France, Portugal and Italy) are losing presence with respect to countries in Eastern Europe (Romania and Bulgaria) and Latin America (Ecuador, Colombia, Peru and Argentina). In this sense, we might conclude that immigration has become more deeply marked by 'Third Worldization'.

In 2006, the majority of migrant workers from outside the EU were concentrated in the service sector (58.I per cent), construction (24.6 per cent), industry (II.I per cent) and agriculture (6.2 per cent) (Pajares 2007: $52)$. If we analyse these figures by gender, we find that 42.3 per cent of total male foreign workers had jobs in construction, while 89.7 per cent of all female foreign workers were in the service sector, more than half of them in domestic employment and somewhat less than half in commerce (ibid.). In terms of concentration by origin, the rotation or displacement of certain collectives in specific sectors or provinces merits remark. For example, in 2002, Moroccans were displaced by Ecuadorians in the countryside of Murcia and by Polish and Romanian women who came to pick strawberries in Huelva (Cachón 2003: 264). Increased immigration from Latin America has also meant there are more female domestic workers from Ecuador, Bolivia and Peru. Finally, the position of immigrants on the labour market also depends on their juncture in legal residence: while newcomers or recently regularised immigrants represent the majority in sectors like agriculture and domestic service, after an initial period of legal residence, migrant workers tend to move into construction and, in the case of women, into services in general (Pajares 2007: 5I).

\subsection{From emigration control to immigration policies}

\subsubsection{Controlling emigration}

Until the I970s, migration policy was concerned with defining, channelling, selecting and keeping count of emigrants. In this regard, throughout the nineteenth century and a good part of the twentieth, the borders of the nation-state functioned more in filtering the exit of people from inside (i.e. nationals) than as an impediment to the entry of people from outside (i.e. foreigners). From the I850s up until the I930s, a series of laws was promulgated to restrict the exit of younger age groups. In the case of men, the measures were intended to ensure there would be enough able-bodied recruits of military age in case of war. As for women, the main argument was that of curbing trafficking in women ${ }^{3}$ and, more generally, prostitution of Spanish women in Latin America (Hernández Garcia 
I98I). Moreover, after the I920s, as a result of the economic crisis and high levels of unemployment in countries of destination, Spanish authorities began to require presentation of a work contract that would guarantee the availability of sufficient economic resources once the person reached South America. The policy's aim was to avoid the Spanish government's incurring heavy costs from numerous requests for forced repatriation.

As a result of these increasingly restrictive emigration policies, illegal exit became a real alternative in Spanish emigration to South America. It is estimated that, in the decade following I9I0, some 40,000 Spanish people illegally emigrated to the Americas. As one observer remarked at the time: '[...] with such restrictive measures the only achievement is that of encouraging emigration (clandestine and contracted, which are the most dangerous forms) because the passenger, faced with the bother and the costs of achieving a passport, will seek other ways of leaving and, if it is difficult to do so here, the same is not true of Bordeaux where, if they ask for anything at all, it is the certificate of residence because anything else they may want isn't worth the paper it's written on' (Vicenti I908: 54). Though the smuggler somehow seems to pertain to today's highly fortified world, this figure (then called a 'clandestine agent') also played an important role in migratory processes at the beginning of the twentieth century (Bullón Fernández I9I3). While then smugglers were necessary to leave Spain, they are now sometimes seen as the only way to enter.

After the economic crisis of the late I920s, the Spanish Civil War, the post-war period and the autarchy of the Franco regime in the I940s, which had the concomitant effect of bringing about a temporary halt to international labour-oriented emigration, the Spanish government attempted to regulate emigration (now to Western Europe) by creating the Instituto de Emigración in 1956. Once again - due more than anything else to the nature of the Franco dictatorship (I939-I975) - the goal was to channel and select emigrants. The regime wanted to encourage the exit of 'wanted emigrants' - that is, poorly qualified or unskilled workers perceived as being loyal to the government. Besides this selective policy, the inefficiency of Spanish bureaucracy and the resistance of some bureaucrats ended up restricting legal emigration towards Western Europe (Pereira 2007: 4). The result was another inducement to illegal emigration. It has been calculated that 5I per cent of Spanish emigrants to Western Europe exited the country illegally4 (Babiano \& Fernández Asperilla in Pereira 2007: 4).

Unlike emigration policy, immigration policy was, up until the mid-I980s, notably vague and lacking relevance. The vagueness was a result of its being a set of rules without the status of law, which went hand in hand with the proliferation of different decrees, countless regulations and treaties of reciprocity, all ensuring that the legal procedure for entry and stay would be a chaotic, confused affair. Relevance was lacking because, given the absence of major immigration flows, these measures were 
not always aimed (either in content or practice) at actually controlling immigration. One such example is the elimination after I959 of the visa requirement for nationals coming from most Western Europe countries, the Americas and North Africa. Even when possession of a work permit was introduced in I9 68 as the necessary condition for working legally in Spain, the resulting illegality did not constitute a problem. In other words, 'illegal immigrants could engage in a working and social life without undue scares or a feeling of illegality' (Izquierdo i996: 142).

In addition to this vagueness and lack of relevance, the first legal immigration measures were not invariably governed by the principle of always distinguishing between nationals and foreigners. Accordingly, the distinction between foreigners from former Spanish colonies (except Morocco), Andorra and Portugal and the rest acquired paramount importance. Thus, unlike 'the rest', foreigners from Latin America and the Philippines enjoyed the same working rights as Spanish citizens after I969 and therefore did not require a work permit. The Citizenship Law (dating back to the 1889 Civil Code) is also a good example of this kind of distinction. Still in force today, the law concedes citizenship after two years of legal residence to people from Latin America, the Philippines and Sephardic Jews, and ten years of legal residence for other foreigners.

Distinguishing between different types of foreigners was justified by an alleged need to cultivate relations with the former colonies (to reiterate, not all of them) and to respond to a historic debt Spain incurred with countries receiving Spanish immigrants for decades (which was not the case with the Philippines, for example). As López Sala (2000: 375) indicates, this differential treatment - the construction of a set of 'privileged foreigners' - could also be explained by an objective to promote or facilitate the immigration (or integration) of 'people like us' in cultural and/or linguistic terms. The outcome of this citizenship law is that a high proportion of foreigners who acquire Spanish nationality (8I.5 per cent in 2006) come from Latin American countries (Ministerio del Interior 2006: 3.I2). In terms of rights, this means an inequality of access to the civil, political and labour rights associated with citizenship. To sum up, this materialises in selective, exclusivist and discriminatory policy (see ZapataBarrero I997).

\subsubsection{Towards an immigration policy}

The end of the Franco dictatorship in 1975 meant radical political change for Spain. This had two far-reaching implications with regard to immigration policy. First, the fledgling democracy immediately ratified the main international human rights treaties, for example, the International Covenant on Civil and Political Rights (1966), the Universal Declaration of Human Rights (I948) and the European Convention on Human Rights 
(I950). Second, the new Constitution (I978) introduced basic matters for the future development of immigration policy as the principle of legal reservation (the obligation to regulate the matter at hand by means of the Ley de Cortes, the basic law regulating Parliament's functioning) and the possibility of both parliamentary and judicial control over all administrative action (Aja 2006: I8). Nonetheless, given the almost imperceptible immigration trickling into Spain at the time, the Constitution did not take up the matter of defining foreigners' rights beyond those recognised as pertaining to any human being, for example, individual freedom and protection of the law.

In fact, it was not until Spain entered the European Economic Community (EEC) in I986 that the need arose to unify and give the status of law to the different regulations, decrees and bilateral agreements (many of them pre-Constitutional) on immigration (Moya Malapeira 2006: 52-54). This need materialised with the urgent promulgation of the Ley Orgánica de Extranjería (Organic Law on Foreigners, LOE, which was also known as the Organic Law on Rights and Liberties of Foreigners in Spain). As López Sala (2000: 258) indicates, Spain's entry into the EEC not only determined the timing of the law, but also its content. Since Spain was not perceived as a country of immigration then, the LOE appeared with the aim of trying to prevent it from becoming a transit or 'immigrant sieve' country for people heading for Northern Europe (Aja 2006: 2I). The result was a restrictive policy that regulated the entry, residence and expulsion of foreigners.

As for regulation of entry and residence, the LOE (and the follow-up post-I986 regulation) introduced the requirements of an entry visa as well as residence and work permits. This meant that the entry of foreigners was now subject to regulation (basically at border posts), while their access to the labour market was conditioned by the country's economic circumstances. Furthermore, the situation of foreigners in Spain was restricted by short-residence permits and non-recognition of the right to family reunification. These limitations, however, did not apply to all foreigners. The regulations that followed the LOE, now in the EEC context, introduced preferential treatment for Community citizens and their families who, unlike non-EEC citizens, enjoyed freedom of circulation and the right to engage in economic activity regardless of the national employment situation. The result was the emergence of a new category of privileged foreigners (Community citizens) in opposition to a newly defined 'the rest' (non-Community citizens).

Along with the distinction between Europeans and 'the rest', the LOE introduced another notch in the hierarchical scale of foreigners in Spain: the distinction between 'legals' and 'illegals'. While the former had some of their rights restricted and others recognised, the latter - labelled the 'international delinquency' by then Spanish Minister of Interior José Bar- 
rionuevo (who would subsequently become a delinquent himself when jailed in 1998 for his activities in Spain's mid-I980s 'dirty war' scandal) were given the bottom-line treatment of detention and expulsion. As a lawyer interviewed by Suárez-Navaz (I997: 7) observed: '[...] those immigrants [illegal immigrants] do not have a single right in Spain. The law anticipates any circumstance. Basically, the message is that if you are "illegal", the state has only one responsibility: to deport you.' In this regard, the introduction of the first immigration law had a twofold effect on migrants' illegality. First, when the conditions of legality (through work and residence permits) were tightened, illegality increased. Those who were working without need of a work permit became illegal. Second, in comparing illegal migrants with delinquents and making them liable to detention and expulsion, a gradual process of exclusion and criminalisation of illegality took place. While being in an illegal situation was not a problem in the early I980s, with the LOE and the regulations in its wake, illegality came to mean being stripped of one's rights and the possibility of being deported at any time (see Jabardo I995).

Nonetheless, tightening up the conditions of legality and illegality had its limits in Spain. These limits were imposed, initially, by rule of law and, more specifically, by the courts (see Marzal Yetano 2009). The dubious constitutionality of the LOE gave rise to complaints filed by the early immigrants' associations, different NGOs and lawyers' colleges. They asked the ombudsman to intervene by lodging an appeal based on the unconstitutionality of the articles that affected the right of meeting and association, internment prior to deportation and the legal prohibition against judges suspending the expulsion orders. As Aja (2006: 23) points out, the ensuing Constitutional Court (1987) ruling meant not only the suppression of these clauses, but also the start of a progressive recognition of rights that the Constitution appeared to reserve exclusively for Spaniards.

Apart from the limits set by the Constitution, reality also swiftly overtook the framework imposed by law. First, the imbalance between a restrictive approach to the entry and stay of foreigners in Spain and a growing demand for migrant workers resulted in the emergence of what can only be described as a model of illegal immigration throughout the I990s (Izquierdo I996). Denounced by immigrants' associations, NGOs and opposition parties during the course of this decade, the manifest policy flaws made it necessary to open up new channels for legal immigration into Spain (by quota) and illegal immigrants' periodic regularisation (by ordinary means or extraordinary regularisation processes as in I99I and I996). Second, immigration was not as temporary as expected. Once again a result of pressure exerted from civil society and opposition parties, the law had to be modified on several occasions so as to regulate the right of family reunification (1994 and I996), extend the duration of permits, improve renovation procedures and introduce, for the first time, 
the permanent residence permit (I996). Moreover, throughout the I990s, the first integration initiatives (though not policy) were introduced (López Sala 2000: 299).

While immigration policy was becoming more sophisticated as a result of needs perceived at the national level, the role of Spain as custodian of Europe's southern frontier continued to affect border control policy. Specifically, Spain's becoming a signatory to the Convention implementing the Schengen Agreement in 1993 and the two subsequent European treaties (Amsterdam and Maastricht) imposed the need for a common policy, which in the case of Spain, meant expanding its border infrastructure and coming up with a more restrictive entry policy. Accordingly, the visa requirement was extended to Morocco, Tunisia and Algeria (I99I), the Dominican Republic (I993) and, much later, Cuba and Peru (200I), Colombia (2002), Ecuador (2003) and Bolivia (2007). The fact that the visa requirement did not come into force for most Latin American citizens until long after the rest partially explains the 'Latin Americanisation' process that immigration underwent during the I990s and a good part of the 2000 s (see Tables 4.4 and 4.5). When the visa was finally imposed, it was ushered in under the pretext of the need for a common European policy. In this regard, as Moreno Fuentes (2005: II6) has pointed out, Europe was crucial not only as a 'pushing factor for the introduction of that measure but also as a way of diluting blame by attributing responsibility to Brussels for a measure that was strongly criticized both in Spain and in the Americas. ${ }^{5}$

\subsubsection{Redefining immigration policies}

The various decrees and regulations that were introduced in response to immigration over the I 990 os soon made reforming the LOE essential. After different bills had been presented by the opposition parliamentary groups, Law 4/2000 (Organic Law on the Rights and Liberties of Foreigners in Spain and Their Social Integration) was promulgated early in 2000. Deemed by some to be 'the most liberal law on the rights of foreigners in Europe' (González \& MacBride 2000: I7I), it aimed to redefine the limits of legality and illegality for immigrants in Spain. On the one hand, Law 4/2000 introduced the right to family reunification in terms that were coherent with the jurisprudence of the European Court of Human Rights and held onto the equality of rights between legal residents and Spanish nationals (freedom of circulation, assembly, association, etc.), though not the right to vote or to be appointed to public office. On the other hand, the law gave illegal immigrants access to health and education facilities in tying these rights to the municipal register known as el Padrón rather than to legal residence. Moreover, it opened up the way for ordinary individual regularisation (known as arraigo - literally 'taking root') and closed off the 
possibility of applying the measure of expulsion because of illegality in work or residence. In other words, according to this law, expulsion would only be applicable to people caught entering Spain illegally, while those already in national territory would be penalised with a fine.

This law on foreigners was passed with general consensus from all the parties in Parliament, unions, immigrants' associations and NGOs (which led to its detractors calling it 'the NGO Law') albeit with notable reluctance from the Partido Popular (Popular Party, PP), which was then in government but only a parliamentary minority. As expected, after achieving an absolute majority in the March 2000 general elections, the PP set about a drastic modification of the legislation, a 'counter-reformation', that led to the passing of a new law (Law 8/2000) at the end of the same year. Arguments wielded in favour of modifying Law $4 / 2000$, even before it was implemented, essentially came down to four (Cachón 2004: 32). First, it was alleged that Law 4/2000 encouraged the inflow of immigrants, having a 'pull effect' on illegal immigration. Second was an appeal to the need to struggle against networks of human traffickers. Third, advocates claimed it was necessary to comply with Community norms and, in particular, those agreed upon at the Tampere European Council meeting and the Schengen Agreement. Yet again, Community requirements (or a misinterpretation of them) were being invoked to justify changes in Spanish immigration policy. Finally, allusion was also made to the need to channel immigration in a legal fashion.

The result was a much more restrictive law that cut back the bounds of legality and expanded illegality as defined by Law $4 / 2000$. In the case of legal immigrants, limits were imposed on questions of permanent residence, representation at the municipal level and the right to family reunification. As for illegal immigrants, they retained some rights such as documentation (in el Padrón), education and complete health care, but were denied others, for example, political and union rights to assembly, demonstrate, associate, unionise and strike. Doubtlessly representing the biggest change in the law, expulsion was reinstated for illegality in either residence or work. One of the issues that drew most criticism in this regard was the introduction of preferential procedures for expulsion within 48 hours, which, in practice, obstructed effective judicial protection (Aja 2006: 3I). Finally, in 2003, two follow-up laws limited further the situation of illegal immigrants. On the one hand, LO II/ 03 facilitated the expulsion of non-resident foreigners who commit crimes, while, on the other, LO I4/03 opened up the (yet to be applied) prospect of the police gaining access to data pertaining to the el Padrón. Since registration with the municipal authorities is a requirement for acceding to social services, NGOs and immigrants' organisations denounced the fact that this measure could have deterrent effects with serious consequences for the rights of illegal immigrants. 
Parallel to redefining legality and illegality, the Spanish government insisted after 2000 on the need to move immigration through legal channels and thus to put an end to the model of illegal immigration that took shape over the I990s. Contracting foreign workers in their place of origin was presented from then on as the solution for legal channelling of migratory flows. To this end, the government signed a series of agreements with Morocco, Colombia, Ecuador, Romania, the Dominican Republic, Poland and Bulgaria. However, as we shall see, access to entry actually continued to be very restricted. The upshot was more illegal immigration not only more, but more than ever because of the burgeoning demand for foreign workers - and new extraordinary regularisation procedures $(2000$ and 200I). In 2004, with return of the Partido Socialista Obrero Español (Spanish Socialist Workers' Party, PSOE) to government, contracting in the place of origin continued as the mainstay of entry policy. With this in mind, but especially in order to guarantee the readmission of illegal immigrants, the government signed new agreements with countries such as Gambia, Guinea-Conakry, Cape Verde, Mali and Senegal. Although the results of the new agreements were once again very partial, the reopening of other channels of entry - as we shall see in section 4.4.I - did finally ease the way to establishing legal channels for part of the inflow.

Furthermore, the new PSOE government launched a further process of extraordinary regularisation in 2005 , which this time covered almost 700,000 applications and, from 2004 on, expanded possibilities for ordinary individual regularisation, the so-called arraigo. Meanwhile, other issues were appearing on the migration policy agenda. On the one hand, immigration was becoming more stable and permanent, and this led to the need to introduce real integration policies (especially at the local and regional levels) with new measures and greater budgetary allocation (see Bruquetas, Garcés-Mascareñas, Morén-Alegret, Penninx \& Ruiz-Vieytez 2008). Another result was that the debate over immigrants' right to vote in municipal elections progressively gathered steam. On the other hand, the economic crisis that started in 2007 left part of the foreign population unemployed. As occurred decades earlier in Western Europe, this placed policies of returning immigrants to their homelands and possible restrictions on the rights to family reunification at the very heart of the political debate on immigration.

\subsection{Restricting entry}

\subsubsection{Defining numbers}

Despite frequent changes in the law (in I985, twice in 2000, in 2001 and 2003) and the regulations that came in their wake (in I986, I991, I996, 
$200 \mathrm{I}$ and 2004), entry policy (with the exception of family reunification and asylum) has always been based on the notion that immigration had to fit the specific needs of the labour market. As Raimundo Aragón Bombín (1995: 108), then head of the Department of Migration, pointed out: '[...] what gets the procedure underway is not the wish of the immigrant but official confirmation that a job offer, formulated in legal terms, is not covered.' This means, first of all, that the entry of foreigners is bound to a specific employment offer. Employers therefore determine both the possibility of entry and the characteristics of the new immigrants. Second, speaking of a job offer that is 'not covered' implies that official approval is only given for job offers that have not been filled by Spanish citizens, members of the European Community or authorised residents. The aim is to ensure that national (or otherwise authorised) workers are not displaced by foreigners. While these two principles have remained constant, the order in which they have arisen and the nature of job offers have been changing over the last two decades.

The passing of the LOE in 1985 laid the foundations for these two principles in linking concession of the work permit with the presentation of a job contract and the "non-existence of unemployed Spanish workers in the kind of work proposed' (Article I7). This system, known as the Régimen General ('general provisions'), neither ordered nor promoted labour immigration, but authorised contracting a specific foreign worker after assessing the situation of the national labour market. Depending on the results of this appraisal, this mechanism could de facto turn the matter of entering the country into something extraordinarily open or extraordinarily closed. What happened, in fact, was the latter. The main consideration was not so much the candidates who presented in response to a specific offer, but the general pool of unemployed. Bearing in mind the previously mentioned upping of the 'job acceptability level' among the Spanish population, the fact that there were unemployed workers did not always mean that there were candidates willing to work in certain jobs. The main result was the systematic denial of requests to contract foreign workers, even when a considerable proportion of these job offers remained unfilled. As Aparicio Wilhelmi and Roig Molés (2006: I49) have noted, only those applications with a 'very precise and exotic profile' had any chance of being authorised. The rest of the jobs were filled by illegal immigrants (Aragón Bombín 1993: 13).

With a view to guiding low-skilled migration through legal channels and breaking the stringency of the Régimen General, the government (still PSOE-led) established an annual labour immigration ceiling after I993. This second mechanism or quota system enabled the contracting of a predetermined number of foreign workers in a specific economic sector and province. The advantage of this, in comparison with the Régimen General, was that the job offers presented under the heading of the quota 
system did not have to be evaluated in light of the labour market. In other words, the needs of the labour market were determined prior to the offer of employment, the employer thus supposedly gaining in terms of certainty and speed in the procedure. Despite the government's sanguinity over the new measure, of the 20,600 places offered by the government in I993, only 5,33 became effective with a job offer by employers. One of the difficulties, as we shall see in the following section, was the complexity involved in contracting foreign workers in their places of origin. Given these limitations, after I994, the government agreed to the quota system's being used for contracting foreign workers who were already working in Spain, most of them illegally. As a consequence of this shift, after this date, the applications based on the quota greatly exceeded the numbers offered by the government. In total, between 1993 and I999, almost I50,000 work permits were offered, over 300,000 applications were presented and about I35,000 employment authorisations were granted (see Table 4.6).

Table 4.6 Quota of foreign workers, 1993-1999

\begin{tabular}{lllll}
\hline Year & Initial & Extension & Applications & Approved \\
\hline 1993 & 20,600 & NA & NA & 5,220 \\
1994 & 20,600 & NA & 37,093 & 25,604 \\
1995 & 8,000 & 17,000 & 37,206 & 19,953 \\
$1996^{*}$ & NA & NA & NA & NA \\
1997 & 15,000 & 9,690 & 67,522 & 24,615 \\
1998 & 28,000 & NA & 65,221 & 27,904 \\
1999 & 30,000 & NA & 96,577 & 19,368 \\
\hline Total & 94,200 & 26,690 & 303,619 & 122,664
\end{tabular}

* There was no quota in this year because there was a regularisation programme.

Source: Izquierdo (2006: 83)

Although politicians (from all parties) insisted on the need to channel labour migration legally, entry policies of the I990s were not at all effective. On the one hand, the Régimen General turned out to be a very limited mechanism because of the impossibility of getting around each application's requisite submission for evaluation vis-à-vis the national labour market situation. On the other hand, the quota system functioned more as an instrument for regularising those who were already working illegally in Spain. This resulted in policy de facto favouring illegal immigration. ${ }^{6}$ The most practicable way to work legally in Spain was to enter or stay in the country illegally and then to find work and regularise one's situation through the quota system or one of the other frequently applied extraor- 
dinary regularisation processes (I99I, I996, 2000 and 200I). While the annual quotas accounted for between 20,000 and 30,000 immigrant workers, it is estimated that a much greater number of immigrants came into Spain each year. For example, while a quota of 30,000 people was authorised for I999, an Ecuadorian newspaper calculated that some 322,000 Ecuadorian citizens had left for Europe that same year, most of them heading for Spain (cited by Carles Campuzano of Catalan nationalist party Convergència $i$ Unió in Spanish Parliament, I8 June 200I). The annual quota allowance also contrasts sharply with the 400,000 immigrants who were regularised between 2000 and 200I (Spanish Parliament, 28 November, 200I).

Since the entry policies were so ineffective, changes made in 2000 to the Foreigners Law (with Laws 4/2000 and 8/2000) once again tackled the need to steer immigration through legal channels. With a view to this, at the start of the second PP mandate (2000-2004), the government insisted that evaluation of the job market always precede any job offer. This meant that a political assessment had to be made of the country's annual needs for immigrant workers, and that the contracting of foreign workers had to occur in their countries of origin so that any immigrant would arrive with a contract tucked under his or her arm. In practice, this meant closing down the Régimen General.7 At the same time, the quota system was presented as the ultimate mechanism for legal immigration into Spain. It was repeatedly stated in Spanish Parliament that the new quota system would finally enable design, management and control of immigration.

First, unlike the Régimen General, the quota system was presented as a way of defining each year how many foreign workers could be contracted by sector and by province. Although the government was responsible for approving the annual quota, Law 8/2000 recognised the participation of the autonomous communities, employers' organisations and unions. Labour requirements identified at the provincial level by employers' and union organisations were assessed by the authorities of the autonomous communities and then sent to the Ministry of Labour, which drew up the final proposal to be rubber-stamped by the government. Second, the quota was also presented as the mechanism that would, for the first time, make it possible to manage migratory flows from countries of origin. Hence, Law 8/2000 specified that the quota was aimed at those foreigners 'who are neither in Spain nor resident in the country' (Article 39). Moreover, after 2002, the job offers presented under the quota system had to be generic in type - that is, designating the job but not determining the worker. This requirement was an attempt to avoid taking candidates already working illegally in Spain, as had occurred throughout the I990s. The change from a system based on designated offers to one based on generic ones meant that, for the first time, the Spanish government was 
responsible for managing job offers and selecting candidates in their countries of origin.

Unlike the political rhetoric that, after 2000 , presented the quota system as the core element in Spain's immigration policy, the data reveal a somewhat limited relevance. From 2002 onwards, the quota system materialised as a forecast of less than 20,000 stable jobs per year. Several factors have been identified to explain the reduced numbers of these projections. First, reference has been made to the timorous attitude of the unions, which were always more in favour of regularising illegal migrants already in Spain than opening up more channels for new immigrants (Aparicio Wilhelmi \& Roig Molés 2006: 158). A second factor is employers' lack of foresight with regard to the needs of medium-term contracting (Consejo Económico y Social 2004: I32; Aparicio Wilhelmi \& Roig Molés 2006: I58; Roig Molés 2007: 292). Third, it is important to note the poor representation of small- and medium-sized firms in the big employers' organisations and thus in the process of determining the quota (Watts I998: 668-9; Aparicio Wilhelmi \& Roig Molés 2006: I58; Roig Molés 2007: 292). A representative from Comisiones Obreras, one of the biggest unions in Spain, indicated that what made the quota forecasts so limited was the absence of any serious study of labour market needs. In his words: 'How is it going to work if the list is drawn up in a week! There's no proper study. It depends on the political interest, on what the relations are like between the government of the autonomous community and the central government, and whether they want to give the impression that it's working. The employers' organisations also improvise when it comes to specifying the demand. There's no seriousness or responsibility' (interview II February 2008, Barcelona).

If the annual quota assignment was limited, still more meagre were the figures for employment offered under the quota system aegis. For example, of the 10,884 and 10,575 stable jobs envisaged for 2002 and 2003, only 3,II3 and 4,762, respectively, were covered (Consejo Económico y Social 2004: 9I-92). Although the number of offers for temporary employment was much higher (I0,520 and 2I,687 of the 2I,I95 and 24,247 jobs envisaged for 2002 and 2003), these figures are less representative since they refer to temporary jobs (basically in agriculture and the hotel and catering sector) that require the return of the immigrants within a limited period of time. To explain the very limited use of the quota for stable employment, many of my interviewees concordantly pointed out the procedures' time-consuming complexity and - as had already experienced in I993 - the difficulties involved in contracting a worker in his or her country of origin. The Consejo Económico y Social (CES), a consultative organ set up by the government in which employers' and union organisations are represented, explained the failure of the quota system in relation to the following factors: 'ignorance of the procedures, their rigidity 
and the time they took, the difficulty for companies in going to foreign countries, lack of trust in signing contracts without having previously been in direct contact with workers, the multiplicity of steps and authorities involved, lack of information given to companies and absence of direct contact with the selecting organisation, and decision-making that did not take employers' desires into account' (Consejo Económico y Social 2004: I32).

Between 2002 and 2004, the shutdown of the Régimen General and the channelling of immigration exclusively by means of the quota system placed extreme limitations on legal entry to Spain. As a result, it once again favoured illegal immigration. As Iratxe Garcia Perez, an opposing PSOE Member of Parliament criticised at the time: 'This restrictive, complicated and badly planned framework has meant that there is less legal immigration and more illegal immigration' (Spanish Parliament 8 April 2003). To give one example of the problem, compared with the 30,000 jobs assigned for the quotas of 2002 and 2003 , more than 400,000 people were registered as residents by local councils in the same period (Izquierdo \& Fernández 2006: 220). The frequent regularisation processes also offer unquestionable proof of the actual volume of the flows. Thus, between 2000 and 2004, the PP government authorised the regularisation of more than 500,000 people. In 2005 (now with a PSOE-led government), almost 700,000 applications for regularisation were registered. This means that more than a million people were regularised in a period of five years, while the entry policy mechanisms still stuck to their figures of between 20,000 and 30,000 .

In 2004, with the newly re-elected PSOE government fully engaged in producing new regulations for the (thrice modified) Law on Foreigners, the need to steer immigration through legal channels was once again confronted. Although this had been the catchphrase of the different governments (both PSOE and PP) since the beginning of the I990s, it was clear that immigration policies had not yet achieved their goal. Following the line embarked upon by the PP, the PSOE government kept insisting that assessment of the labour market had to precede the job offer, and that immigrants should be contracted in their countries of origin. However, heeding the recommendations of the CES report (2004: I29), instead of giving priority to the quota system to the detriment of the Régimen General, the new government opted for combining both forms of entry. While the quota system made it easier to cover the generic types of work offer more quickly (without a previously assigned specific worker), the Régimen General made it possible for designated jobs to be offered as well, along with those in cases where a would-be employer had operated with insufficient foresight and was thus unable to work through the quota system.

In order to adapt the 'old' Régimen General to the aims of the 'new' policy, the 2004 regulations limited contracting to those foreigners ' $w$ wo 
reside outside Spain and who have obtained the appropriate visa' (Article 49). As with the quota system, this requirement was an attempt to prevent the Régimen General from becoming de facto a mechanism for regularising the situation of immigrants already in Spain. The 2004 regulations also proposed the quarterly production of a list of jobs that could not be filled, known as the catálogo de puestos de trabajo de difícil cobertura, ordered by sector and province, enabling the contracting of foreign workers without prior case-by-case assessment of the national labour market. This did not concern the number of work permits to be offered (as in the quota system), but provided a description of jobs without giving a quota. The production of this catalogue made it possible, first, to give a political definition of the economic sectors that needed foreign workers. Once again, this decision was to a great extent the task of the autonomous communities, the employers' organisations and the unions at the provincial level. Second, there was hope that the catalogue would also speed up the process of contracting. Instead of the uncertainty and slowness, characteristic of the I990s, that came with depending on a case-by-case assessment of the labour market, contracting procedures would now start from the knowledge that if a job appeared on the list, offering it to a migrant worker would be authorised.

The results of this recent change in entry policy have been various. If we focus on the quota system, we must note clear continuity with regard to what happened between 2002 and 2004 . First, the forecasts for stable jobs continued to be quite limited, while actual employment offers made under this heading were still more limited. Second, the quota system continued to consolidate as an instrument for temporary contracting in sectors such as agriculture and the hotel and catering trade. While the quota system continued to represent quite a limited form of entry, after 2004 the Régimen General became the mechanism par excellence for entering the country. The difference is important: while between June 2004 and June $2007,14,229$ offers of stable employment were authorised through the quota system, as many as 352,307 authorisations were processed by the Régimen General over the same period (Ministerio de Trabajo 2008). Consolidation of the Régimen General, as compared with the quota system, should be explained by the fact that it was not limited by an annual ceiling. As will be shown in the next section, what would also account for the increased relevance of the Régimen General after 2004 is the existence of significant social networks among immigrants who have already arrived and those yet to come.

\subsubsection{Recruiting migrants}

Rarely has the relationship between immigration and the labour market been questioned. According to different government and social agents, immigration was and had to be a phenomenon that was first and foremost 
about labour. Consequently, as we saw in the previous section, the entry of immigrants has always been linked to the existence of a job contract: only those already holding a job could enter the country. Nevertheless, in Spain this has been more of a legal fiction than reality. While politicians have asserted over and over again that it necessarily had to be thus, in practice, most immigrants first entered the country and only found work afterwards. This means that, instead of entering as legal immigrants (with the contract tucked under his or her arm), the majority has been illegal for some time and only later (with contract in hand) has been able to regularise.

In the I990s, this fact was not only tolerated but recognised. If the worker could not count on somebody in Spain or the employer had no contact in the country of origin, there was no mediation, which made contracting at origin practically impossible. The most common scenario was that a worker would already be in Spain, would work illegally for a period and, only when the working relationship got underway, would immigration procedures begin. If the worker was granted a work permit, he or she would then return to the country of origin, collect the visa and re-enter the country as a legal immigrant worker. Contracting at destination was thus more the rule than the exception. In these cases, as Arango and Suárez (2002) have observed, social networks were the first and most important means of locating and recruiting immigrant workers. The relations of trust and, above all, the added value of recommendations (across workers or between employer and worker) were seen to maximise the chances that the migrant would 'work well' (ibid.: 542-543). Similarly, parish groups and NGOs played the role of job mediators. Unlike agencies offering temporary work, used in particular by recently regularised workers, these entities guaranteed not only 'good workers' but also 'good employers' and mediation in case of conflict (ibid.: 55I-553).

Since 2002, in order to prevent immigrant workers from being contracted at the destination point, job offers made under the quota system became basically generic: defining the job but not the worker. The employer then ceased to be responsible for the selection. Or, better said, the Spanish state (along with the states of origin) became the intermediary between employers at destination and workers at origin. Besides the Spanish government's political commitment to channelling an indeterminate number of its immigrant quota from the countries of origin to Spain, the agreements with Morocco (September I999 and July 200I), Colombia and Ecuador (July 200I), Romania (January 2002), the Dominican Republic (February 2002), Poland (May 2002) and Bulgaria (October 2003) provided that the labour administration in the countries of origin would be ultimately responsible for candidate selection.

In this regard, the function of the Spanish government has been more of manager than recruiter. In Spain, the Ministry of Labour and Social 
Affairs receives generic offers from the employers, confirms whether they fit with any category not yet filled under the quota system and sends on the offer to the Spanish consular representation in the country of origin. Here, the Spanish consular representation communicates the offer to the country's authorities, after which the latter respond with information regarding workers' availability to meet the requisite characteristics for the kind of work being offered. If the answer is affirmative, a process of preselection and interviews begins in which authorities from both countries are present, along with the employer or business organisation representing the employer. Despite the constant presence of the Spanish state throughout the process, its actual role is rather limited. As one civil servant from the Foreign Affairs Ministry observed: 'Selection at origin is in the hands of the governments of the countries of origin. The negotiations are basically carried out between the governments of the countries of origin and the employer. The Spanish state only guarantees the smooth running of the process. We do what the authorities at origin allow us to do. But generally this is very little because they are usually very keen to be in control' (interview I3 May 2005, Madrid).

Although, since 2002, the quota system has been presented as the main form of legal entry, the reality has been very different. One basic matter when it comes to explaining why it has not worked is, once again, the intrinsic difficulty of contracting in the country of origin. For Arango and Sandell (2004: I2), this boils down to whether 'there exists any company that really wants the state to be the one that decides the skills of its workers'. Similarly, one employer asked: 'How can one employ a worker one has never seen?' (interview I5 February 2008, Barcelona). This simple question partially explains why the quota system has worked in some sectors and not in others. While in agriculture and some production-line jobs the individual profiles of the workers tend to be less important, in sectors like domestic service, small businesses or the hotel and catering trade, trust and prior relationships between worker and employer are paramount. In order to respond to this shortcoming, the Organic Law I4/2003 and, later, the Regulations of 2004 introduced the possibility of authorising a three-month entry period for job-seeking. This was not opened up as a universal option, being only for specific sectors (like domestic work) or for children and grandchildren of Spanish-born people. ${ }^{8}$

Although the job-seeking visa seemed to solve problems arising from the legal fiction of policies based on contracting in origin, results have so far verged on negligible. For example, in 2007 (within the annual quota agreement), 455 job-seeking visas were offered in the domestic service sector and 500 job-seeking visas for children and grandchildren of Spanish-born people in the country of origin. These figures clearly testify to the scant relevance of the job-seeking visa and hence of an entry policy that includes (not only in practice but also by law) contracting at destina- 
tion. There are several reasons for this. First, there is the question of how to manage this process in the country of origin. As the above-cited civil servant in the Ministry of Foreign Affairs noted: 'We still haven't found the formula. Who do you give the visa to? How do you select them? Who pays for the return ticket if they don't find work? In the end, aren't you encouraging them just to come here more than anything else?' (interview I3 May 2009, Madrid). Second is the matter of how to deal with the problem of managing (if it has to be managed) at the point of destination. In this regard, a civil servant working in the Catalan government's employment agency observed how the job-seeking visa implied a lot of responsibility for different branches of the administration inasmuch as it lets in people 'who don't yet have a job', adding: 'How are you going to bring them in if you don't know if they're going to find work?' (interview I2 December 2007, Barcelona). These doubts highlight a basic point: immigration is still tied to a job contract and is therefore dependent on employers. At least for the moment, it is thus difficult to imagine an immigrant entering Spain without backing by an employer.

In this sense, immigration policies have always been headed for the same dilemma: entry is tied to a job contract, but contracting in the country of origin does not seem to work. During the I990s, the difficulties of contracting at origin arose from a lack of mediation mechanisms. In the new post-2002 quota system, problems sprang from the limitations of state intervention in both selecting the workers for employers and, in the case of the job-seeking visa, permitting the entry of immigrants without prior existence of a job contract. The outcome, as noted above, has been more illegal immigration. It is illegal immigration, as we saw in the previous section, brought about by the very low numbers of people permitted to enter the country, and it is illegal immigration, as we now see, caused by the difficulties occasioned by stipulation of the job contract as a prior condition. In both cases, the result has been the same: the most feasible way to work as a legal immigrant in Spain is to enter the country illegally or stay in it as an illegal immigrant, find a job and, only after that, achieve regularisation.

This twofold legal production of illegality seems to have been somewhat attenuated by the reintroduction of the Régimen General in 2004. On the one hand, as already noted, the 'new' Régimen General removes the rigidities of the 'old' one by introducing a catalogue of hard-to-fill jobs, which reduces the complex paperwork and the uncertainty of having to submit every single case to an evaluation of the labour market. This catalogue does not assign an annual quota of jobs, but is simply a list of occupations in which it is possible to contract foreign workers. Accordingly, in contrast with the quota system, the number of people entering is not restricted a priori. On the other hand, increased immigration and the concomitant existence of significant social networks between immigrants 
who have already arrived and those who are yet to come seem to have finally provided a solution to the problem of mediation. Unlike the situation in the I990s, many workers in countries of origin now have someone they know in Spain, or employers (through their workers) have contacts in the country of origin. Relations built on trust and the added value of a reference, therefore, are not only characteristics of contracting at the country of destination, but can also happen in the country of origin. In this regard, one union representative observed: 'The Régimen General, in fact, is not in itself a form of contracting at origin, but it is managed by relatives and acquaintances in Spain. The families and acquaintances are incredibly effective employment agents!' (interview 6 February 2008, Madrid).

We might conclude, therefore, that immigrants' social networks have ended up fulfilling the function of mediation that the state has not been able to achieve. Thanks to these networks, contracting in countries of origin does at last seem to be possible. Nevertheless, it is not exempt of its own dilemmas. Although immigrants' social networks finally permit mediation between the worker in the country of origin and the employer in the country of destination, their existence introduces the doubt or suspicion that not everyone who comes to Spain under the Régimen General does so for strictly employment reasons. As the words of a civil servant in Barcelona's central government delegation made clear: 'Children and husbands come through family reunification. The rest (siblings, friends and cousins) come by means of designation in the Régimen General" (interview 2I April 2008, Barcelona). The long time taken up by procedures from the moment entry is authorised to receiving the visa to enter Spain seems to aggravate this 'suspicion'. This same employee said: 'If the procedures take a year and the employer holds out, there might be other reasons for contracting a worker. If they get to the end, maybe it's because the job offer isn't real' (interview 2I April 2008, Barcelona). However, this begs the question of whether this mechanism, being so time-consuming, is adequate when the offer is 'real' or, rather, when the job offer does not go hand-in-hand with incentives beyond employment considerations in the strict sense.

\subsubsection{Selecting migrants' origins}

To return to the words of Aragón Bombín, what gets the process underway is not the will of the immigrant, but the existence of a job offer. In other words, entry does not depend on the immigrant but on the employer. Accordingly, as noted above, employers determine the entry and characteristics of the immigrants as well as their countries of origin. This is clearly the case with the Régimen General. Under this system, the employer selects a foreign worker, requests work and residence permits and, if response is positive, the worker initiates the procedures in his or her country of origin to receive an entry visa. The origin of the worker in 
these cases is not prior determined. It is true that obtaining the visa takes longer in some countries than in others, depending on how much work the consulates in the countries of origin must contend with. Nonetheless, by law, if there are no national (or otherwise authorised) workers available, the employer is free to contract a foreign worker wherever he or she wishes.

With the quota system, this decision is more conditional, however. In the I990s, the quota system only determined the sectors in which it was possible to contract a specified number of workers each year. The origin of the workers, in the case of the Régimen General, depended on the employer. Yet after 2002, contracting in the countries of origin via the quota system came to be possible only in those countries with which the Spanish government had signed agreements (Morocco, Colombia, Ecuador, Romania, the Dominican Republic, Poland and Bulgaria). This means that, at first, it is the Spanish government that decides. Once the decision is taken, the criterion for determining the distribution of the quota then remains in the hands of the employers. It is the employers who, on presenting a generic offer of work, 'propose' the country where contracting will take place. In practice, this dual decision becomes contradictory: the state's reasons for choosing some countries over others do not always coincide with the demands of the employers.

To illustrate, agreements that are as significant (in terms of flow size) as the one signed with Morocco have barely come to fruition. The Moroccan administration's efficiency notwithstanding, many interviewees agree that this is mainly due to the reluctance of employers to contract Moroccan workers. As a civil servant working in the Catalan government's employment agency observed: 'The Moroccan government has a huge interest in encouraging contracting at origin. We do, too. When I went to visit the office in charge of this in Morocco, they did a good job of selling it to me, and I came back very enthusiastic. But the employers don't want to contract workers over there. They're very loath to do so. They say there's corruption and use the excuse of language (when they actually speak many more languages than we do). In brief, there's political volition to channel the flows, but there's no response from employers' side' (interview I2 December 2007, Barcelona). The result is that, while contracting in the country of origin through the quota system had the primary goal of moving existing flows through legal channels, ultimately everything depends on the employers. Thus, in cases where employers are reluctant, the legal ways of entering remain barred and, accordingly, legal immigration does not represent a real alternative to illegal immigration.

This disparity between the state's and the employer's choices is also patent in the most recent bilateral agreements signed with Gambia (2006), Guinea Conakry (2006), Cape Verde (2006), Mali (2006) and Senegal (2007). In exchange for these countries' collaboration in the struggle 
against illegal immigration and, above all, with the condition that they agree to the repatriation of their citizens, Spain promised to facilitate legal immigration from these countries. The terms of the deal, according to a high-level official in the Foreign Affairs Ministry, were clear: 'The most recent agreements have been made in order to guarantee readmission. Again, in order to give something in return, a system for channelling legal immigration has been opened. The governments of these countries see legal immigration as a bargaining chip. And we owe them that' (interview I3 May 2008, Madrid). Nonetheless, once again, everything depends on the employers. While Spain needs employers to contract workers from these countries in order to fulfil its part of the agreement, the employers are not so keen to comply. The representative of an employers' organisation in the hotel and catering sector said: 'For the last two years they've been going on and on about contracting workers in countries like Gambia, Niger or Senegal. But what business have we got there? They're illiterate in their own dialect. Why should we go to Senegal? For us, Latin America's much easier. They speak the same language, are better trained, and have experience in the sector. Why take the longer and more difficult route when there's one that's short and easy?' (interview 9 May 2008, Madrid).

While some agreements have amounted to virtually nothing, others have been given a great deal of attention by employers. Such was the case of Poland. We might speculate as to why employers have opted to contract Polish workers and not Moroccans. In fact, both the mass media and academic literature have played up a perceived greater 'docility' and 'propensity for integration' of Poles - being European, Catholic and mainly women. These reasons apart, the fact is that, in some cases, the quota system ended up promoting one kind of immigration over another. This was especially obvious in the strawberry fields of Huelva where, after 2002, Moroccan workers (including those in a legal situation working in this rural area for a long time) were progressively replaced by female Polish workers even though Poland was never traditionally a country of immigration towards Spain. When NGOs, immigrant organisations, unions and some opposition parties condemned this situation, the government stayed adamant that it did not have the last word on the quota, but the employers did. As then Minister for the Interior Mariano Rajoy stated: 'What is clear is that the employers contract whomever they want. It would be strange if the government said, "No you contract people from such and such a country for us." We fix the quota and then the employers decide' (El País I2 June 2002).

The tension and, in some cases, contradiction between the state's and the employer's 'reasons' finally resulted in a dual policy. First, contracting in the country of origin via the quota system was - and is still - presented as the best way to steer migratory flows through legal channels, thereby putting an end to illegal immigration. Second, since it is the employer 
'who decides', this might go no further than a mere pact based on good intentions or, in the case of most recent agreements, a promise (not kept) on condition that governments of the countries of origin agree to repatriate their citizens. To reiterate, 'the employers decide'. They decide not only not to contract in certain countries that were once traditional sources of immigrants, but to do so in countries that have not traditionally played such a role. This meant favouring some flows over others or, better said, opening up some while (at least legally) closing others. The El Ejido case illustrates this perfectly. In February 2000, the murder of a young Spanish woman by a mentally disturbed Moroccan who shortly before was turned away by a health centre led to a three-day campaign of violence against Moroccan immigrants. Immediately afterwards, Moroccan workers demonstrated and went on strike for several days. This process resulted in the El Ejido Agreement, according to which different administrative organs took it upon themselves to ensure better living conditions for immigrant workers in the municipality. Despite the administration's 'good intentions', in subsequent seasons Moroccan workers found that they were being replaced by women from Poland. While the state did not promote this replacement, it let employers take this new direction by adopting - what at least seemed to be - a position of simple laissez-faire.

\subsection{Between guestworkers and citizens}

\subsection{Position on the labour market}

Immigrants to Spain are only 'welcome' or 'accepted' in economic sectors with labour shortages. Under the Régimen General, this restriction means that the application for contracting a foreign worker is subject to a caseby-case evaluation of the labour market situation and, more recently, to the quarterly production of a list of sectors and provinces where contracting foreign workers is authorised. In the case of the quota system, contracting foreign workers has been circumscribed by setting an annual quota of foreign workers per sector and province. This means that entry policies have slotted immigrant workers into certain jobs or, to put it another way, have fixed the field of possibilities with regard to contracting them. This is what Cachón (I995: III-II2; 2003: I9; 2009: I62) calls 'the institutional framework of discrimination' - that is, when market 'preferences' turn into 'requisites' or 'prescriptions' in legal regulation.

This field of possibilities has restricted not only the entry of immigrant workers, but also their initial stay in the country. As Aparicio Wilhelmi and Roig Molés (2006: I72) point out, if the whole system is founded on the particular characteristics of the offer that enables authorisation of entry, it would not be consistent if, after taking up the job, the foreigner 
could then leave it behind for another job with vastly differing characteristics. On the basis of this argument, the initial work permit (for the first year) tends to be limited to the economic sector and province for which entry was authorised. Nonetheless, administrative practice in imposing these restrictions and then controlling them is very deficient. For example, it is not uncommon for workers who begin in Murcia's agricultural sector to end up a few months later working in the construction sector of Madrid or Barcelona (ibid.). Technical problems and deficient means seem to explain this gap between the law and its practice. As a Barcelona lawyer I interviewed explained, the computer system used to contract workers does not monitor how long they have held a residence permit and, as a result, allows changes of economic sector, even in the first year of residence (interview I7 March 2008, Barcelona).

While the initial permit is, at least according to the law, limited to a specified sector and province, its validity does not depend on the employer who gets the process underway. The worker is hence free to change employers as long as he or she remains in the same sector and province for which authorisation was given. There seems to be general consensus on this point. To illustrate, when the Catalan employers' organisation CECOT proposed introducing a contractual clause that would oblige workers who left their job before a stipulated initial period to pay for their training costs and transport from their country of origin, this was challenged and labelled 'illegal' not only by the unions, but also by the Catalan government itself (El País 25 February 200I). In this regard, we might conclude that, while entry of an immigrant cannot be conceived of without an employer behind it, the immigrant-employer tandem breaks down when it comes to staying in the country. Explanation must be sought for the impossibility of curbing the freedom of immigrants once they are in Spain. While the reasons underlying this are clear, the actual outcome is not.

First, employers are often fearful of 'losing' their workers after having contracted them in their countries of origin. As CECOT's president: 'It wouldn't make sense if a company made an investment and advanced a certain amount of money to bring somebody here and then, after a week in that company, the worker was contracted by another company. The original employer would be wasting time and money on something that gave no returns, while the second employer wouldn't be paying out anything' (El País 25 February 200I). Second, the unions and the state, though condemning the measures proposed by CECOT, are also critical of employers who fail to keep their foreign workers. The unions, for their part, attribute the high degree of labour mobility of immigrant workers (and hence the permanent need for 'new immigrants') to the poor working conditions offered by these employers (interview with the aforementioned union official in Barcelona, II February, 2008). The state sees in these employers an 'out-of-control' 
gateway to the Spanish labour market. Accordingly, government delegations, like that in Barcelona, tend to reject applications to contract immigrants by companies that have previously failed to keep their immigrant workers for the first year (interview with a civil servant in the Government Subdelegation, Barcelona, 2I April 2008; interview with a representative of an employers' organisation, 6 November 2007, Barcelona).

The only foreign workers whose work permits, once they have entered the country, do depend on the employer are seasonal workers (under the quota system). In this case, the employer is not only responsible for the entry of the foreign worker, but must also offer adequate housing, guarantee work for the duration of the permit, organise the journey to Spain and cover at least one-way travel costs. The (this time) 'invited' worker must commit to return to his or her country of origin once the working relationship has concluded. Complying with this requisite guarantees the prospect of filling other future job offers (often from the same employer) that appear in the same sector. Although this could not be described as 'sanctioned bondage', per se, the fact that not only entry into the country - but also remaining (and returning) - depends on the employer gives rise to problematic dynamics (see Zapata-Barrero, Faúndez García \& Sánchez Montijano 2009: 20-22). For example, a group of Colombian seasonal workers and the unions CCOO and UGT jointly filed a formal complaint against the rural employers' organisation Unió de Pagesos for obliging them 'to accept harsh conditions in order to be able to return the following year' (El País 30 August 200I). These circumstances might be taken as confirmation that the foreign worker's dependence on the employer can in fact restrict his or her labour rights.

Another result of this dependence is a matter of what in other countries came to be called cases of 'running away' or absconding. In Spain, however, this happens at the point of having to return home and not so much vis-à-vis having to work for only one employer. In 200I, CCOO denounced the fact that more than half the workers contracted by the Unió de Pagesos did not return to their countries once the agricultural season was finished (GES 2002: I2). In 2004, UGT published a study on the province of Huelva where the same phenomenon was estimated at a rate of 25 per cent (El País 27 May 2004). While unions have been claiming for years that contracting seasonal workers has become just one more way of legal entry and illegal stay (interview with a CCOO representative, II February 2008, Barcelona), the employers have responded with the argument that the return - or non-return - of workers to their countries of origin is not their responsibility. The words of a representative of CEOE, the biggest employers' organisation in Spain, are clear in this regard: 'Seasonal workers should return to their countries of origin. Of course a lot don't. It's another way of slipping through the net. But what are we supposed to do? 
The employer pays for the ticket. But we are not the police and we don't have any way of monitoring whether they get on the plane or not' (interview 7 February 2008, Madrid).

While the field of possibilities associated with contracting immigrants is limited during the period of entry and initial stay, these constraints disappear with the first renewal of the work permit after one year. From then on, the immigrant is free to work wherever he or she wishes, independently of the national labour market situation. As such, the field of possibilities comes to be the same in many respects as that of any national worker. In other words, and using again Chachón's words (I995: III-II2), the 'preferences and dynamics of the market' might still be present, but they no longer translate into 'requisites and prescriptions' in terms of legal regulations. This has the effect of gradually shifting immigrant workers into the economic sectors hitherto reserved for national or authorised workers. As already mentioned, it would seem that there is a clear trend: the longer the period of residence, the smaller the presence in sectors like agriculture and domestic service. However, this raises questions: Who fills their positions? Does the employer need new immigrants whose working activity is once again immobilised by sector and province for the first year? Are there some economic sectors that are therefore dependent not so much on immigrant labour, per se, but - above all - on newly arrived immigrant labour?

\subsubsection{Taxation}

In Spain taxation on foreign workers has never been meant to control migrants' presence in the country or to reduce employers' reliance on migrant labour. Legal migrants pay taxes and contribute to social security like any other worker. In this regard, taxation results from the inclusion of all workers in the general system of taxation and social services. However, due to the legal position of foreign workers, taxation does have particular implications for them. Specifically, since 2004, the work permit (whether the immigrant has it on arrival or via regularisation) can become effective only when the worker has registered with social security. Moreover, the permit's renewal depends on how many months of paid contributions there were during the validity period of the authorisation that the immigrant hopes to renew.

This means that immigrants' legal status largely depends not only on their working, but particularly on their working formally. This is especially problematic if we take into account the magnitude of the informal economy in Spain. For example, in 2004, UGT estimated that in Madrid, alone, I23,000 immigrants had a work permit but were not paying contributions (El Mundo 24 August 2004). While, for national workers, participating in the informal economy might mean not having access to 
certain social security services (like the right to unemployment benefits or the old age pension), for foreign workers this can also mean not being able to get the permit when it is due for renewal or becoming illegal (again). As Izquierdo and Léon (2008: I7) note: 'It is the jobs without a contract that make the stay illegal.' To avoid this situation, many immigrants have opted to pay their social security contributions themselves (interview with an NGO representative, 7 February 2008, Madrid; interview with a researcher, 16 April 2008, Barcelona). As we shall see in the next section, immigrants frequently end up having to look for a 'false' or 'doing-a-favour' phantom job, and paying the social security contribution themselves while continuing to work without a contract in the informal economy.

As far as political rhetoric, immigrants' contribution to the social security system was one of the main arguments wielded to indicate the need for (and advantages of) the 2005 regularisation process. In September 2005, Minister for Labour and Social Affairs Jesús Caldera declared that, thanks to the process of regularisation and the inclusion of regularised immigrants in the social security system: 'the system is fully consolidated' and 'exceeded payment forecasts by more than 3,000 million euros' (El País 8 September 2005). While during economic booms, immigrants' contribution to social security has been used as a main arguments in favour of regularisation, in times of crisis it has become the main justification for encouraging their return home. At the start of the Zapatero Government's second term (2008), new Minister for Labour and Immigration Celestino Corbacho announced a scheme of 'voluntary repatriation', the mainstay of which was reimbursement of the totality of unemployment insurance (40 per cent in Spain and 60 per cent in the country of origin) in exchange for renouncing the residence permit and any return to Spain within a minimum period of three years. In this regard, paying for social security has been used indiscriminately (and very swiftly) as a motive for inclusion or as an incentive for return.

\subsubsection{Temporality}

Not only has the entry of foreigners depended on a specific job offer, but so has their remaining in the country. During the first five years of residence, renewal of the permit (after the first, third and fifth years) is bound to the existence of current employment, a job offer or receipt of unemployment benefits tied with a previous job. Since 2004, with the aim of preventing 'false' or 'doing-a-favour' job offers, renewal has also depended on the amount of time worked within the validity period of the permit that the immigrant wishes to renew. This essentially means that renewal has come to be linked with the time that social security payments have been made. Maintaining legal status, therefore, has depended on effective and formalised integration into the Spanish labour market (Cabellos 
Espiérrez \& Roig Molés 2006: II8-II9). The link between permit renewal and having work has meant that only those immigrants who can prove they have the necessary economic resources to survive can renew their permit. As Suárez Navaz (2000: I3) has remarked: 'If there’s money, there are documents.'

In contrast, immigrants unable to demonstrate their integration as workers during the first five years of residence run the risk of losing their legal status and, in most cases, fall back into illegality. This loss of legality has been far from infrequent due to the extremely high numbers of temporary immigrant workers and the instability that characterises the Spanish job market. For example, of the eight million job contracts signed by foreign non-Community workers between 2004 and 2007 , only one in ten was for an indefinite period (Ministerio de Trabajo y Asuntos Sociales 2007: 8). Loss of legal status has been even more common with the initial renewal after one year of residence. As Cabellos Espiérrez and Roig Molés note (2006: II8), this is because of the difficulty in proceeding to effective and stable integration after only one year of residence. Furthermore, as we have already seen, the initial permit tends to immobilise immigrants in sectors that are rejected by national workers and notable for their greater degree of instability. In this regard, the 'institutional framework of discrimination' which, as previously noted, transforms 'market preferences into requisites or prescriptions in legal regulation' (Cachón I995: III-II2), has only increased job instability for the new arrivals and, as a result, their legal instability. In other words, the law contributes to the precariousness of the immigrant's work situation and this selfsame precariousness frequently contributes towards his or her 'illegalisation' at the end of the first year.

Another cause for loss of legal status is the long waiting period involved in completing application renewal paperwork. This slowness, principally brought about by a general breakdown in the management of foreigners' affairs, has not infrequently resulted in a dropping of the job offer on which the application renewal is based. Consequently, in the absence of a job, either the application is turned down or obstacles are placed in the way of subsequent renewal (depending once again on integration into the labour market) of the permit that was originally granted. Loss of legal status due to renewal paperwork is what Izquierdo (I996: 150) defined in the mid-I99os as institutional production of the undocumented'. In 2004, Minister of Labour and Social Affairs Jesús Caldera indicated that when the government had come to power in March that year there were 400,000 immigrants' files that had not been dealt with, and I0०,००० were applications for the renewal of residence and work permits. As the minister observed: 'This inability to respond to renewals obliges us to deal with the paradox that, if we don't act quickly, the administration will thrust into illegality people who, to the present time, have been 
in a legal situation and who will, as a result of this change of status, lose their jobs' (Spanish Parliament, I3 September 2004).

Whether caused by the impossibility of demonstrating effective and formalised integration into the Spanish labour market or the time-consuming paperwork involved in the renewal processes, this loss of legality is indubitably a major factor contributing to the enormous proportions of illegal immigration in Spain up until 2005 (see next section on regularisations). Taking into account the significance of illegal entry and stay, it is thus possible to understand the persistence and dimensions of illegal immigration in spite of frequent regularisations, namely those of I985-1986, I991, I996, 2000, 200I and 2005 (see Cabellos Espiérrez \& Roig Molés 2006: II4). The figures for regularised immigrants who have lost this status after some years are very significant. For example, of the 23,887 immigrants regularised in 1985 , only 58 per cent were still in a legal situation in I990 and, of the IIO,000 regularised in I99I, less than 75 per cent still retained this status one year later (Ramos Gallarín \& Bazaga Fernández 2002: 9).

To get around the effect that administrative delay has had on the loss of legality among foreign residents, Law 4/2000 included the provision of 'positive administrative silence' for renewal applications. This meant that, six months after the application for renewal, the administration's silence was as good as a permit renewal. As a result of this measure, according to Caldera, 306,838 applications for renewal were granted by default between 200I and 2004 (Spanish Parliament, I3 September 2004). In recent years, despite significant improvements in administrative capacity, it appears that many renewals continue to be conceded by means of positive silence. Although a generally presumed renewability has made it possible, in part, to overcome the effects that administrative delays previously had on migrants' legal status, the measure is by no means problem-free. Sometimes the situation is a veritable catch-22. For example, red tape-ridden delays in some provinces thwart applications from being filed and, hence, from immigrants being eligible for the rule of positive silence (Cabellos Espiérrez \& Roig Molés 2006: I2I). Several of the lawyers I interviewed also mentioned the fact that many employers and even the Social Security Department require a certificate of administrative silence which, given the bureaucratic collapse in offices dealing with foreigners affairs, tends to be very difficult to obtain (interview with a CCOO representative, II February 2008, Barcelona).

What seems paradoxical at a basic level is that a first or recurrent lapsing into illegality, which is so typical of the Spanish model and the cause of a considerable part of its illegality, should not have led to a reconsideration of renewal policies and, more specifically, a review of the temporality that threatens the legal status of foreign residents in their first five years. In other words, why has the period provided for renewal not 
been extended so as to secure migrants' legal stability? Why continue with this guestworker approach when immigration is turning out to be increasingly stable and permanent? The answer, as noted above, is that despite the stability and permanence of immigration in Spain, it is still difficult to visualise an immigrant who is not primarily an immigrant worker with a job. Leaving aside the applicants for political asylum and family reunification initiatives, immigrants' entry and stay (in the first five years) continue to depend on their position in the labour market: they can only enter the country when they have a job contract tied to a specific sector and province and they can only renew their permit if they can demonstrate being integrated into the formal job market.

Despite the temporality and contingency, immigrants still become established residents and not only obtain permanent residence, but also Spanish citizenship. Immigrant workers manage to become permanent immigrants and, later on, citizens. Their temporary status and situation as 'guestworkers' are not forever. After a number of years, which may depend on their oscillations from legality to illegality, they eventually achieve definitive status and the boundary between insiders and outsiders becomes - at least legally - blurred. The figures in this regard are very indicative. While throughout the I990s most foreigners had a one-year permit, this tendency changed in recent years. The number of permanent residence permits thus rose from 200,000 in 2002 to 851,000 in 2007 (Izquierdo \& Léon 2008: II). In relative terms, and despite the volume of immigratory flows in these years, the proportion of permanent residents came to represent 36 per cent of the total non-Community legal migrants. As for naturalisations, more than 292,000 foreigners acquired Spanish citizenship between 2000 and 2006 (see Table 4.7).

Table 4.7 Evolution of numbers of foreigners granted Spanish citizenship, 1995-2008

\begin{tabular}{cccc}
\hline Year & $\begin{array}{l}\text { Number of foreigners } \\
\text { granted citizenship }\end{array}$ & Year & $\begin{array}{c}\text { Number of foreigners } \\
\text { granted citizenship }\end{array}$ \\
\hline 1995 & 6,756 & 2002 & 21,810 \\
1996 & 8,433 & 2003 & 26,556 \\
1997 & 10,311 & 2004 & 38,335 \\
1998 & 13,177 & 2005 & 42,860 \\
1999 & 16,384 & 2006 & 62,339 \\
2000 & 11,999 & 2007 & 71,810 \\
2001 & 16,743 & Total & 347,518 \\
\hline
\end{tabular}

Source: Ministry of Interior (1990-2008) 


\subsection{Regularisation: an entry policy?}

\subsubsection{The first regularisation}

The first Ley Orgánica de Extranjería (LOE, Organic Law on Foreigners) in I985 was accompanied by an extraordinary regularisation process. The reasons for embarking on this course, according to Aragón Bombín (I996: 54), were 'an awareness that there was already a significant stock of immigrants in an illegal situation and the desire to move on and begin a new stage free of the burden of the past.' The process was not exclusively aimed at foreign workers, but at foreigners in an illegal situation residing or working in Spain. These residents or workers' included, first, foreigners 'whose presence was already illegal in terms of previous legislation' (Carrillo \& Delgado I998: 24). In other words, it was aimed at illegal immigrants who had, up until then, gone about their working and social lives without scares and without any awareness of illegality (Izquierdo I996: I42). Second, the process also aimed to regularise foreigners whose status became illegal with the change to the law. Namely, it is likely that some immigrants from Latin America, the Philippines and Equatorial Guinea taking up this regularisation had formerly been legal immigrants who, until the promulgation of the new law, had not needed a job permit in order to work in Spain (Izquierdo I989: 47).

This regularisation process, like the LOE itself, was launched without much discussion. Spain, at the time, still saw itself as a country of emigration or transit place for immigrants going to other European countries. The regularisation was thus primarily perceived as a process for issuing documentation to immigrants who were already in the country - which is to say, as a means of 'tidying up' the prevailing administrative chaos. It was presented more as way of providing requisite documents than regularising illegal immigrants. A foreigner without proper documents was to go to the closest police station to his or her residence, fill out a form and eventually submit documentation necessary for a residence permit (proof of economic means and marital status) or the job permit (job contract and registration for social security). To the extent that it was mainly understood as a process of providing requisite documents for foreigners, administrative responsibility fell within the jurisdiction of the Ministry of Interior through the official documentation offices known as the Comisarías Generales de Documentación.

During the nine months the process lasted (from July i985 to March I986), which included two successive extensions, filed were 43,8I5 applications for regularisation, 38 ,I8I of which had positive results. Concerning the nature of the requests, 5I per cent were for a residence permit, which means that less than half the immigrants asked for work permits (Aragón Bombín \& Chozas Pedrero I993: 28). In terms of social profile, the regularised immigrants fell into two very different groups (Izquierdo I989: 
69). The more numerous comprised working-age immigrants from poor countries with scant educational qualifications. Notable among them were immigrants of African origin (mainly Morocco, Senegal, Gambia and Cape Verde), accounting for 40 per cent of the total applications filed. In clear contrast, the second group, which accounted for 26 per cent of the applications, consisted of immigrants from the European Community (mainly Portugal, the UK, Germany and France). Most were retirementage European citizens, married, no longer working and with sufficient educational and economic resources.

Although this regularisation process made it possible to 'normalise' the situation of some illegal immigrants, the government considered the results to be limited. This official evaluation is difficult to understand unless one bears in mind that, according to the sociological research group Colectivo IOÉ, the number of illegal immigrants then was as high as 350,000 , although another report put the figure at 260,000 (Arango \& Suárez Navaz 2002: III). If these figures are any guide, they indicate how the regularisation process failed to 'normalise' the great majority of illegal immigrants. In its I99I proposal for a new regularisation process, the Asociación para la Solidaridad con los Trabajadores Inmigrantes (ASTI) formulated four possible causes for the 1985 regularisation drive's failure (ASTI i991: 6-I2).

One of the primary causes was scarcity of information. While the mass media repeatedly covered promulgation of the new law, little was said about the regularisation process. Second, ASTI noted the distrust of all actors involved. For example, no attempt had been made to stress the fact that presenting oneself at a police station to apply for regularisation would in no way harm the immigrants. Neither were there sufficient guarantees for employers to feel confident that the administration would not initiate actions against them. A third factor was the administration's inability to deal with the process, which was highlighted by media attention devoted to long queues of applicants waiting to be attended. Fourth, according to the ASTI report, the fact that information was given exclusively in Spanish was yet another obstacle to people with only rudimentary knowledge of the language. Besides these factors of a more institutional nature, the Ministry of Interior's documentation office observed that the greatest impediment for the regularisation of those who needed a work permit was having to present a job contract. From this, Izquierdo (I989:34) concludes that employers did not help their workers to obtain the documentation they needed.

Apart from the figures for regularised immigrants, it is also important to bear in mind the strikingly low proportion of people who managed to maintain their legal status over time. As noted in the previous section, one of the causes of illegality has been lapsing or relapsing into a situation of illegality at the time of permit renewal. The 1985 regularisation drive ex- 
plicitly brought this trend to bear for the first time. Only 58 per cent of people who were regularised in 1985 were still in a legal situation in 1990 (Aragón Bombín \& Chozas Pedrero I993: 28). This trend was even more evident among Moroccan immigrants: only one fifth of those who applied for regularisation still had legal status two years after the process. Of those who became 'illegal' over time, 47 per cent 'disappeared' after trying to apply without providing documents that could pave the way to obtaining any kind of permit, while 30 per cent achieved some kind of residence permit (valid between six months and a year) but never renewed it. A question arising about the Moroccan immigrants concerns how many never filed in the first place, or never renewed, because they had returned home or moved on to other European countries. As Izquierdo (I989: 6I) wondered, did the Moroccans head for Spain as their final destination or was it just a steppingstone?

\subsubsection{The second regularisation}

In I990, the left-wing party Izquierda Unida - Iniciativa per Catalunya presented the government with an urgent interpellation concerning the situation of immigration in Spain. During the subsequent parliamentary debate, the government committed to preparing a report on the situation of foreigners in the country. After presentation of this document, which was produced in collaboration with the Ministry of Interior and the Ministry of Labour and Social Security, Spanish Parliament approved a proposición no de ley, a Green Paper in which the government was urged to undertake political measures on four points: control and channelling of migratory flows; the struggle against illegal immigration; giving an international focus to migratory issues; and reforming the administrative apparatus (López Sala 2000: 283). Further, the Green Paper envisaged 'adopting the necessary measures to complete the process of regularisation carried out in 1985 , while also paving the way for groups of foreigners working in an illegal situation, who arrived in the country after that process and who can demonstrate their insertion in the labour force or arraigo ["rootedness"] (Proposición no de Ley r99r: Article 4)

Unlike the previous procedure, which was defined, above all, as a process of providing documentation for foreigners, this regularisation project had a significant work component. One resulting manifestation is the fact that the applications were not filed in the Ministry of Interior's Official Documentation Offices, but in the Provincial Departments of Work and Social Security and some employment offices. Another novelty was the involvement of social organisations, unions and NGOs. According to Aragón Bombín and Chozas Pedrero (I993: 65), recognition of the social organisations and their role in the application and development of 
the process were decisive. As we shall see, this alliance between the government and social organisations has been a constant in subsequent regularisation procedures. From then on, working to regularise the maximum possible number of immigrants became, for many organisations, the best way to champion the rights of immigrants in Spain. As Suárez Navaz (2000: 8) points out, although it cannot be said that the volunteers, activists and social organisation experts became simple accomplices in the government's actions, this regularisation did manage to 'give credibility to the state's inclusive gesture' and thereby to create a general consensus over the need to 'normalise' the situation of immigrants.

During the six months the process lasted (from June to December I99I), I35,393 applications were filed. Of these, I09,I35 were granted. Concerning the kinds of applications filed, 83.7 per cent of the permits were conceded to under the assumption of permanent residence as of May I99I and a firm offer of formal and stable work (85 per cent) or a viable self-employed project (I5 per cent) (Aragón Bombín \& Chozas Pedrero I993: IOI). This confirms that, while the I985 regularisation process was primarily focused on regularising residents, I99I's was particularly concerned with regularising workers. The immigrants' origins and profiles partly explain this difference. While, in I985, a significant number of immigrants came from other European countries, in I99I, most immigrants came from non-European countries and represented the typical profile of the economic immigrant. The biggest group comprised people from the Maghreb (notably, 44 per cent of the applicants came from Morocco), followed by Latin America (mainly from Argentina, Peru, the Dominican Republic and Chile) and Asia (Philippines, China and, to a lesser extent, Pakistan and India).

As Izquierdo (1989) notes, the main point of a regularisation drive is not the final number of people regularised, but the cover and continuity of a legal situation. How many, then, were still illegal after the process and how many had lapsed back into illegal status over time? If we look at the figures for initial rejection, we find that of the 135,393 applications, I8,933 (I4.8 per cent of the total) were denied. The main reason for rejection was lacking proof of residence in Spain prior to I5 May I99I (Arango \& Suárez Navaz 2002: I24-5). As observed by many illegal immigrants who were in Spain at the time, this underscores the significance of any written proof that could reveal illegal stay. According to Suárez Navaz (2000), after the I99I regularisation, papers (really, any paper) took on huge importance, representing prospects for regularisation. This is what she defines (2000: IO) as 'the fetishism of papers': dual acceptance of an inanimate object to which magical qualities are attributed and whose semblance suggests possessing an intrinsic exchange value not actually there. Vis-à-vis immigrants, Suárez Navaz further remarks: 'It is not unusual for them to proudly show you these papers-shields they carry 
round in their pockets, while collecting all the rest, just in case, in a plastic bag full of frustrated statuses and identities.'

Renewal figures once again demonstrate how easily legal immigrants fall back into illegality. They reveal a fine line separating the two conditions. Numerically speaking, it is significant that there were 22,000 cases of non-renewal (20 per cent of which had initially been regularised) and 6,000 rejections of renewal (5.5 per cent). Again, one needs to ask: what about those who did not apply? How many of them left Spain and why did those who remain decide not to try for renewal? To what extent were those who did not file excluded by the fact of not being able to maintain or prove their employment situation? Apart from those who did not renew their permits because they did not file to begin with (the reasons for this will never be known), another 6,000 people lost their legal status when their application for renewal was denied. Taking into account the almost I9,००० who did not manage to achieve legality because their initial request was turned down, it would seem that the regularisation procedure itself produced almost 25,000 illegal immigrants. In other words, I7 per cent of the immigrants who applied for regularisation were excluded along the way. If one adds those who disappeared or excluded themselves from the process, the figure would peak at 25 per cent. The next question to raise is one that Izquierdo (I996: I49) asks: what is the point of a regularisation process that either keeps a significant proportion of the immigrant collective in a situation of illegality or returns them to this status?

\subsubsection{The third regularisation}

The reality of immigration soon swamped the legal framework set out by the I985 law. In I99I, Spanish Parliament approved a Green Paper pressing the government to take a series of specific immigration measures. Five years later, the first immigrants' associations, different NGOs and institutions like the ombudsman and lawyers' colleges pushed for another reform that would culminate in I996's modification to regulations for applying the LOE. The new regulations introduced, for the first time, the permanent residence permit and also regulated the right to family reunification. A series of norms were decreed to speed up procedures for obtaining residence and work permits, while improvements were introduced with respect to renewal and duration of the permits. Once more, the changes in immigration policy were accompanied by a process of regularisation. This time, the aim was to regularise those foreigners who, due to requirements of the previous regulations, had not been able to renew their permits. In this sense, it was more a process of re-documentation than regularisation in the strict sense of the word.

In fact, the 1996 formalities were restricted to those foreigners who had arrived in Spain before I January I996 and who had held work and 
residence permits, or just a residence permit issued after the I985 law came into force. As with the previous process, this regularisation drive also included relatives of residents with legal status. Another significant element is that regularisation was not dependent on the job market. While in the prior process, obtaining work and residence permits was contingent on a firm job offer, this time the applicant only had to make a simple declaration of intent as to the job or jobs he or she wished to perform. The reason for this unlinking, something largely pushed for by the unions, was to avoid workers being dependent on their employers. The driving idea was that ties between regularisation, job offer and employer placed the immigrant in a vulnerable position that might encourage the selling of job offers, extortion and other immigrant exploitation under the threat of withholding the offer.

This process lasted four months (from April to August I996). It was placed within the relevant organs of the Ministry of Interior (for residence permits) and the Ministry of Labour and Social Affairs (for work and residence permits). Of 24,69I applications, the total number of successful attempts was 75 per cent for work and residence permits and 28.4 per cent for residence permits only. The profile of immigrants who applied for regularisation was similar to that of those regularised in I991: essentially economic immigrants coming from African countries (almost a quarter from Morocco), Latin America (I3 per cent) and Asia (with Chinese immigrants accounting for 4.6 per cent) (Arango \& Suárez Navaz 2002: I33). It should be recalled that these figures are not a gauge of illegal immigration, but rather of the numbers and the nature of the immigrants who had returned to a status of illegality.

\subsubsection{Regularisation through the quota system}

Besides I996's regularisation process, which was limited in terms of those even deemed 'regularisable' and their final numbers, the main form of regularisation comprised entry policies from I994 until I999 (with the exception of I996) and, in particular, the quota system. As noted in the previous section, the quota was used to contract foreigners already working (illegally) in Spain. Once a job offer was authorised, the foreigner had to apply for a visa in his or her country of origin or, as was the practice, at a Spanish consulate in a neighbouring country. On other occasions a visa exemption was granted. With the visa (or exemption thereof), the foreigner legally re-entered Spain or ultimately received without having to leave - a work and residence permit. According to the Ministry of Labour and Social Affairs, only io per cent of those who obtained a work and residence permit through the quota system 'really came from outside the country' (Spanish Parliament, I9 February I997). If between I993 and I999, almost I50,000 work permits were granted through 
the quota system, this would suggest that some I30,000 people were regularised - a number not far from the sum of foreigners regularised in the processes of i99i and I996.

Compared with the extraordinary regularisation processes, the quota system introduced important new details. First, regularisation via the quota system did not require a prior period of residence in Spain. As a result, it was now possible to acquire legal status without having to accumulate 'papers' or 'documents in proof of residence. Second, as discussed in the previous section, the quota system required a specific offer of employment. It thus ended up functioning as a means of regularising immigrant workers with employment. In this regard, unlike the I996 process, the tie between immigrant, job offer and employer was total. Third, it was not just a matter of finding employment. The job offer had to come under one of the economic sectors headings annually defined by the state. In effect, this meant that it was only possible to achieve regularisation in jobs that were rejected by national or authorised workers. Finally, and again unlike the extraordinary regularisation drives, the quota system did not permit the regularisation of all illegal immigrants with prior specified characteristics. The number of jobs was limited. As a result, those who got in first were regularised (hence the long queues) and once there were no more offers under the quota system, there was no chance of being regularised until the following year.

\subsubsection{The fourth regularisation}

The changes in the Law on Foreigners with the promulgation of Law 4/2000 in February 2000 were accompanied by another extraordinary regularisation drive. As Arango and Suárez Navaz (2002: I4I) indicate, this reconfirmed the institutional tendency that turned 'extraordinary processes into a dependent variable of legislative change'. Another constant that was yet again substantiated was the influence of immigrants' associations, other social organisations and the minority political parties. As happened in I99I as well, the pressure for legislative change was introduced into the Parliament by the minority parties (this time, the leftwing party Izquierda Unida, Catalan nationalist party Convergencia y Unió and Grupo Mixto, a set of parties without their own independent representation in Parliament). While the main opposition party (PSOE) ended up leaving its mark on the process of defining the new policy, the $\mathrm{PP}$ - in government but with a parliamentary minority - was, if anything, against the different bills presented and the launching of a new extraordinary regularisation process. This climate of confrontation, exacerbated by the coming general elections (March 2000) and the subsequent legislative counter-reform (which ended up with the promulgation of Law 8/2000) influenced not only the debate around the 
regularisation process, but also the conditions of its being carried out.

As on other occasions, the main objective of the regularisation process of 2000 was to cut the numbers of illegal immigrants right back to zero so that the new law could go into effect without hindrance. Similar to I985, an attempt was made to wipe the slate clean by means of resolving the unforeseeable effects caused by the application and management of the previous law. In effect, the aim was to incorporate or reincorporate immigrants whose illegal status had been brought about by the I98 5 LOE. This time, it involved not only regularising the immigrants who had been made illegal again at the time of renewal (as with the process of i996) but also those whose application for the initial permit had been turned down. As a representative of the Comisaría General de Extranjería (police headquarters for foreign nationals) stated, the aim was 'to correct the circumstances that had obstructed the renewal or approval of permits' (in Arango \& Suárez Navaz 2002: I84). Since this was the objective, the regularisation process was aimed at foreigners 'who were in Spanish territory before 1 June 1999' and who 'can demonstrate that they have previously applied for a residence or work permit, or who have had such a permit in the last three years' (Royal Decree 239/2000).

These requirements reveal the extent to which the regularisation process was designed on the assumption shared by the majority of stakeholders (from political parties, to immigrants' associations and social organisations) that illegality was mainly the result of having lost papers. The reality, however, turned out to be very different when it quickly became evident that many illegal immigrants had not yet had the chance to apply for a permit. Accordingly, if the aim was to take illegality figures back to zero, the requisites for regularisation needed to be modified. This is precisely what led the government to extend the stipulated period for proving that, at some point, a work permit had been applied for. By this means, the application for a permit, which would make it possible to apply for regularisation, ended up being something that could be presented up until ten days after the start of the process. This is to say that it was now possible to apply for a permit and then, on the basis of that request, ask for regularisation. While this requirement ceased to limit the actual feasibility of access, bringing it into effect resulted in long queues of people waiting their turn and the overriding sensation of having to deal with a confusing, arbitrary bureaucratic labyrinth.

On the other hand, de facto elimination of the condition of having applied for a permit now made proof of residence in the country the main requirement for obtaining regularisation. Although this requisite was maintained until the end of the regularisation drive, the difficulty of meeting the requirements had its effect in modifying administrative practice. In their exhaustive study of the 2000 regularisation process, Arango and Suárez Navaz (2002) point out that most of the documents 
stipulated as proof of residence before I June I999 (among them a work and/or residence permit, licences, tax declarations, social security registration and registered work contracts) were very difficult to present unless the immigrant had had some period of legal status. As one representative of Valencia Acoge, an organisation that assists newly arrived immigrants, noted: '[...] there are people who have notched up the time (having lived in Spain for some time), many years in fact, but they don't have enough documentation ... because they've never been sick; they don't have proof of medical treatment; they're afraid to go to any organism or service and there's no way they can get this proof' (in ibid.: 388).

Lacking official documents, many immigrants opted to make up their dossiers. Backup (not definitive) proof consisted of any kind of document bearing their name and the date of issuance in print. This revived the fetishism of papers described by Suárez Navaz in the context of the I99I regularisation. Furthermore, this 'almost desperate' need for 'papers' gave rise to all sorts of falsifications carried out in the name of friendship and solidarity, as well as for money. As a member of an NGO in the Canary Islands remarked: 'Any kind of bill was presented, especially mobile phone bills. Yes, yes, any document with a date on it. So what happens? A lot of them had friends with businesses, or friends with a shop and they made them out back-dated invoices' (in ibid.: 395). While this was very common practice, success was patchy. In some provinces letters from home addressed to the immigrant were accepted, along with medical certificates, proof of cohabitation or traffic tickets, but in others, such proof was deemed totally insufficient.

This disparity in the criteria applied - or the discretionary judgement of the different government offices and departments at the provincial level - is not very different from that noted in the previous section with regard to the concession of initial permits. Nonetheless, since this was an extraordinary process, the inconsistency was still more evident. In El País, journalist Tomás Bárbulo denounced the disparity shown when the Barcelona branch of Foreigners Affairs and Immigration only admitted 29.I per cent of applicants, in the nearby city of Girona 82.2 per cent were approved (El País 23 December 2000). In the same article, members of different NGOs were quoted as saying that, given this inconsistency of criteria, it was the norm to send rejected files to other provincial branches in order to obtain final approval. Along with this discretionary practice by sub-branches of the administration, also noteworthy is lack of consistency across local governments, regional governments, NGOs and unions when it came to giving information and receiving applications. If their participation once again (and perhaps more than ever) facilitated the extension, effectiveness and efficiency of the process, it also introduced major distortions. It is particularly important to note that while NGOs and unions played a fundamental role in providing information and, especially 
in selecting files, their rigour also worked against those applicants who were excluded. ${ }^{\text {Io }}$

As for specific results, in the four months the process lasted (from 2I March to 3I July 2000), a total of 246,086 applications was filed, most of them in Madrid (22.6 per cent), Barcelona (20.9 per cent), Almeria (8.5 per cent) and Murcia (7.5 per cent). As with previous processes, the great majority (90 per cent) requested a work and residence permit. In other words, this was clearly a work-oriented type of immigration. Again, in clear contrast with estimates made by most of the stakeholders, 94 per cent of the applications were filed by immigrants who had not had a permit beforehand. This means that the majority was not in an administrationcaused irregular situation due to previous policies. As for their origins, trends observed on previous occasions continued. Most came from Morocco (26.6 per cent of the applications filed), followed by Latin America - the biggest groups being from Ecuador (9.3 per cent) and Colombia (6.I2 per cent) - and then Asia - mostly from China (4.8 per cent) and Pakistan (4.6 per cent) (Dirección General de Ordenación de las Migraciones 200I).

As for the initial rejection figures, of the 246,086 who filed applications, only 146,78 I received a favourable response. This is to say that almost I00,000 applications were turned down, or 40 per cent of the total applications initially filed. Most of the rejections were because immigrants were unable to demonstrate their presence in Spain before I June I999. To reiterate, not all documents (mobile phone bills, letters from home, traffic tickets, etc.) were accepted as proof of residence. More precisely, not all were accepted in every sub-branch of the provincial administration. For example, while in Madrid only I7 per cent of the applications were turned down, in Barcelona the figure was as high as 7I per cent (Rius Sant 2007: I99). There were also significant differences in rejection figures by country of origin. While the figure for Moroccans was 26 per cent, it was 2I.6 per cent for Chinese, 22.9 per cent for Pakistanis, I2.9 per cent for Colombians and 9 per cent for Ecuadorians (Dirección General de Ordenación de las Migraciones 200I). While the spokesperson for the Asociación de Trabajadores Inmigrantes Marroquíes (Association of Moroccan Immigrant Workers, ATIME) attributed the differences to 'discrimination based on religion or geographic origins' (El País 23 December 2000), it is possible that uneven distributions by territory (for example a relatively greater presence of Moroccans in Catalonia than in Madrid) and different ways of using social networks were also decisive factors in the variation of results.

Unfortunately no data are available for renewal figures. Nevertheless, it is important to highlight two basic factors that, although present in earlier regularisation drives, now offered unprecedented clarity. First, it is much easier to obtain a work permit by way of a regularisation process 
than via normal entry procedures. While ordinary procedures require a specific offer of employment, the regularisation processes have tended to be dissociated from the job situation of the immigrant. In the process of 2000 , this disconnect was still more evident when proof of residence in the country became the main requisite for obtaining a permit. Thus, while the mechanisms for entering the country make job stability the main requirement, the regularisation processes ended up making (illegal) residence its virtually single condition. Second, as a result, although the renewal processes impose less burdensome conditions than the procedures for entering the country, these requirements are more difficult to meet than those the immigrant had to satisfy in order to be regularised. In other words, while written proof of residence is enough to be regularised, after one year it is necessary to demonstrate stable employment (in accordance with the usual procedures for entering the country) in order to maintain legal status.

It is thus the first renewal, rather than obtaining the initial permit, that ends up being the main obstacle. Even if the immigrant manages to achieve legal status, this is of no use if, after a year, he or she has not spent the stipulated amount of time working or does not have a firm job offer. As seen in the above section, the condition of being legal does not only depend on working, but also on working in a legal, stable way. This largely explains the situation of administration-caused illegality and relapsing into illegal status, which have been so characteristic of the Spanish model. As Cabellos Espiérrez and Roig Molés (2006: II6) remark, the main outcome is that '[...] the situation that is thus accepted actually strips the system of any sense, inasmuch as it delays the real test that gives access to stability of residence to a time when, in fact, it has become very difficult to expel the foreigner or return him or her to the country of origin. This means that denying renewal of the permit only annuls any chance of regular work for the foreign resident, who will stay on in Spain in any case.'

\subsubsection{Aftermath of the fourth regularisation}

Although the year 2000's process regularised more illegal immigrants than ever before, the number of those excluded was much higher than rejections in earlier processes. Accordingly, with the aim of completing a regularisation process that was perceived as being unfinished, the reform of the new law on foreigners (Law 8/2000) included a regulation that contemplated an official review of the rejected applications. A few months later, in February 200I, the government passed a decree that would be in force for three months, by virtue of which the applications of foreigners who, meeting all the requirements, had had their applications turned down because of being unable to demonstrate they had been in Spain since before I June i999, would be reviewed, without those affected 'having to 
do anything'. This decision meant that 61,365 files out of the almost Io०,००० that had been rejected were favourably reviewed. At the same time, the measure generated considerable negative feeling among people who, knowing they did not fulfil the requirements and advised by NGOs and unions, decided not to file their applications for regularisation.

Along with this second-chance review of applications from 2000, a series of events - and related pressures exerted by immigrants and civil society - led to further regularisations. First, in January 200I, a traffic accident in Lorca, Murcia, killed thirteen Ecuadorian immigrants with illegal status. The accident brought to light not only the fact that Law 4/2000 and the subsequent regularisation had excluded many people, but also the poor living conditions and exploitative situations many illegal immigrants were having to bear. Moreover, the immediate intensification of inspections of working conditions in the fields of Murcia meant that many illegal immigrants (mostly Ecuadorians) lost their jobs a few days later. As a result of all this, in the same week as the Lorca accident, some 300 immigrants marched to the city of Murcia, denouncing the precariousness of their situation and demanding regularisation (El País II January 200I). Although at the time the government representative in Murcia, José Joaquín Peñarrubia, alleged that it 'was impossible to attend to' these petitions (ibid.), the government launched a programme of voluntary homeland return for Ecuadorian illegal migrants. The government's pledge consisted of a return ticket to Ecuador, from which the immigrants could undertake paperwork to achieve a pre-entry contract and then return to Spain with regularised status. However, the response again exceeded government expectations. The lack of resources and possibilities for attending to the almost 25,000 Ecuadorians who took up the government's offer meant that, in the end, more than 20,000 were regularised without having to return to Ecuador.

The Ecuadorians' march to Lorca was immediately followed by other mobilisations (church lock-ins, hunger strikes and demonstrations) in Barcelona, Lepe, Murcia, Cádiz, Sevilla, Granada and, later, Madrid. Once more, therighttopapers-undertheslogan 'Papeles paratodos' ('documents for everyone') - was the main claim. Be this as it may, forms of protest and arguments wielded by the differentactors varied. First, the ombudsman, the union Comisiones Obreras and the Moroccan Workers' Association (ATIME) labeled the second-chance assessment of applications that were dismissed in the 2002 process as discriminatory. They decried the fact that some people who filed the application despite not being able to demonstrate arrival in Spain before I June I999 were rewarded. Meanwhile others who, in an identical situation, had opted - or had been advised - not to apply, were preventedfromachievingregularisation. Second, the Ecuadorian collective, as Laubenthal (2007) observes in her comparative study on the movements of sans-papier in different European countries, employed post-colonial 
arguments in claiming regularisation by presenting themselves as belonging to the Spanish madre patria ('motherland'). ${ }^{\text {II }}$ Third, those groups - such as Pakistanis, Bangladeshis and Indians - who could not justify their demands with historical ties or cultural similarity, appealed to an extent whereby illegality meant 'deportation and maybe death'. When participating in hunger strikes, their central message was that their willingness to die for legal status, or their likely death due to deportation, made their legal residence status an existential necessity (Laubenthal 2007: II8).

After considerable government reluctance, the administration's different sub-branches at the provincial level finally negotiated. They agreed to regularise the immigrants participating in lock-ins and other protests. This gave rise to yet another conflict of equity. Why regularise only those immigrants who took part in lock-ins, demonstrations and protests? What about those who, meeting the same requisites, were not negotiating with the different sub-branches? Given this inconsistency in criteria, the government eventually decided to extend the agreements reached in some autonomous communities to the country as a whole. In June $200 \mathrm{I}$, the government thus declared that, from then on, there would be maximum flexibility in interpreting the concept of stability of social and employment conditions - i.e. arraigo - and humanitarian considerations would be taken into account in legalising immigrants. This specifically meant opening up the regularisation process to all illegal immigrants who could demonstrate their residence in the country before 23 January 200I, and prove their arraigo by actual or potential incorporation into the job market, by having previously enjoyed a situation of legal residence or having family ties to Spanish citizens or foreigners with legal residence.

In the months the process lasted (until July 200I), 35I,269 applications were filed - the majority in Madrid (II8,268), Barcelona (4I,583) and Murcia $(27,697)$. Of the total applications, 223,428 or 63 per cent were accepted (Garrido Medina 2003: I2). This meant that, as in 2000, more than Io०,000 illegal immigrants were excluded. Yet again, the rejection figures were unevenly distributed. While the overall figure was 37 per cent, it rose to 65 per cent for Barcelona, mainly affecting immigrants coming from Pakistan and Bangladesh. With regard to the origins of immigrants who requested regularisation, it should be noted that, for the first time, the Ecuadorians (and not Moroccans) were most numerous. After them, the largest groups were Moroccans, Colombians and Romanians.

\subsubsection{The fifth regularisation}

After 2000, the closing of the Régimen General and the channelling of work-oriented immigration exclusively through the quota system greatly limited the possibilities for entering Spain legally. The administration- 
caused illegality of those who lost legal status was now more than ever aggravated by the illegality caused by the difficulty (if not impossibility) of legal entry. The effect was immediate: just three years after the regularisations of 2000 and 200I, the number of illegal immigrants in Spain was now calculated to be as high as one million. In this situation, and after the victory of the PSOE in the general elections of March 2004, the new government was faced with the need for legislative change. Presented with the alternative to modify the law for the fourth time or to approve a new regulation of the law, the government took the second option. With broad support from the employers' associations and unions, a new bill, the Reglamento de la Ley de Extranjería, was approved in December 2004.

In general terms, the law now included wider-ranging legal directives for ordinary regularisation on the basis of arraigo and, as remarked in the previous section, it recovered the Régimen General as the main instrument for legal immigration to Spain. Moreover - and this was the key short-term aspect of the new norms - a different process of regularisation was prescribed, this time called 'normalisation'. While previous processes of regularisation were justified by the need to resolve the unforeseen effects arising from application of the earlier law and, more specifically, by the need to reduce the numbers of administration-caused illegal immigrants, this time the stated goal was that of reducing the black economy. In the words of the then State Secretary for Emigration and Immigration, Consuelo Rumí, the '[...] main objective of this process is to bring to light jobs in the black economy' and thereby 'to put an end to the social costs of illegal employment, since immigrants in an irregular situation do not pay taxes or contribute to Social Security' ( $A B C$ 2I January 2005). It should be pointed out, as the NGO SOS Racismo did at the time, how the discussion about illegality thereby shifted (largely because of the central role played by the unions) to curbing the black economy and boosting the welfare state by means of incorporating illegal immigrants (mainly as contributors). ${ }^{\text {I2 }}$

While the PSOE, the unions and the employers' associations spoke of 'normalising' things and bringing to light the black economy (to the point of speaking of 'regularisation of employers' rather than workers), the PP, just as it had done in 2000, continued to harp on the 'pull effect' of any extraordinary process of regularisation. Ignacio González, then vicepresident of the Autonomous Community of Madrid, opined that the announcement of the regularisation was a 'message that gives the impression that it is possible to enter this country illegally and to find an easy way of regularisation and legalisation, and what this is bringing about is a "pull effect", whatever way you care to look at it' (La Razón 27 August 2004). Fellow PP member and former Minister of the Interior Ángel Acebes was - besides beating the drum of the 'pull effect' - of the view that this regularisation 
increased the 'pressure on social security, education and employment', and that it was against EU policy (El País 9 February 2005). Once again, the EU was being used to justify changes in, or criticism of, Spanish immigration policy. While the Minister for Labour and Social Affairs presented the regularisation process as being in conformity with a study carried out by the European Commission, ${ }^{\mathrm{I}}$ Acebes denounced the government for going against European policy agreed upon at the Seville Summit (ibid.).

If the EU was hitherto wielded as an excuse or argument to defend a policy while rarely interfering directly, the 2005 regularisation did indeed give rise to misgivings, and comments thereof, by several member states. For example, Germany's Minister for the Interior at the time, Otto Schilly, expressed concern that immigrants momentarily being regularised in Spain might freely move on to France or Germany within a few years. In a similar tone, the erstwhile Dutch Minister for Immigration Rita Verdonk noted that ' $[. .$.$] what we must see is how such initiatives affect the rest of Europe'$ (El País I2 February 2005). Faced with these fears and aiming to avoid disagreements, the Luxembourg Presidency of the Council of the EU and European Commissioner for Justice, Freedom and Security Franco Frattini suggested establishing a mechanism for mutual information. This concerned not only with regard to regularisations but to any measure that would affect immigration and asylum legislation, especially when there was a chance of its affecting other member states.

Such reservations probably also explain the government's zeal in reminding the public that this was simply a normalisation of workers, its prime objective being to stamp down on the black economy and consolidate the welfare state. Furthermore, the different government representatives added that this regularisation had nothing in common with the massive regularisation of foreigners that the PP carried out in 2000 and 200I, when the main requirement was written proof of residence, with a mere traffic ticket, letter from home or random invoice being commonly accepted. The requirements for achieving regularisation in 2005 were certainly different from those of the previous ones. As on other occasions, the task was to prove arraigo laboral and presence in Spain before a certain specified date, but there were also two significant new features. First, the regularisation initiative did not depend on the foreigner, but on the employer. Second, the period of residence in Spain had to be demonstrated by way of registration in el Padrón, a municipal registry.

As for proof of stable employment (arraigo laboral), it was the employers who had to go to the offices of either of Foreigners Affairs or Social Security to request legalisation of their workers. The contract had to be for 40 hours per week for a minimum of six months (three months in the agricultural sector). In the case of domestic service, if the person worked part-time (a minimum of 30 hours per week) and for more than one employer at a 
time, it was possible for the individual to request the permit on his or her own behalf. In all cases, final authorisation was contingent on registration with - and/or contributions being paid to - social security. This condition aimed to ensure that the employment bond was real and effective, rather than a simple job offer or just a potential working relationship. The resulting permits were valid for one year and tied to a particular sector and province.

In the case of proof of residence, the worker had to appear in el Padrón before 7 August 2004 and was to be in Spain when filing the application. This requisite was one of the more controversial. Though it was not utilised, a law (LO I4/O3) had opened up the possibility for police to access data in el Padrón. The measure had been a disincentive to registration, with the result being that many foreigners had been unable to gain access to the regularisation process. Accordingly - and under pressure from the employers' association CEOE, the ombudsman, the General Council of Spanish Lawyers and several autonomous government, town and city councils - the government agreed to accept what was called empadronamiento por omisión ('default registration'). By virtue of this device, the worker who could demonstrate residence in Spain before the stipulated date could request retroactive municipal registration. Although this measure made it possible to extend regularisation to all those residents in Spain who had not registered in el Padrón, it also reintroduced a significant discretionary element in making access to regularisation contingent on the administrative practices of each town or city council.

By the end of the process's three-month duration (from 7 February to 7 May 2005), 691,655 applications were filed. Of this total, 83.6 per cent were granted. The rejected applications numbering less that 45,000 contrasts with the over I00,000 rejected in the regularisations of 2000 and 200I. Most of the applications were filed in Madrid (I7I,32I), Catalonia $(\mathrm{I39}, 480)$ and Valencia (Io8,496). By origin, the biggest group was from Ecuador (I40,020), followed by Romania $(\mathrm{II} 8,546)$ and Morocco $(86,806)$. Of all the applications filed, 58.9 per cent were men and 4I.I per cent were women. As for economic sector, most applications came from the sectors of domestic employment (31.6 per cent of whom 83.4 per cent were women), construction (20.7 per cent of whom 94.9 per cent were men), agriculture, livestock and fishing (I4.6 per cent), hotel and catering (I0.3 per cent) and commerce (4.7 per cent) (Observatorio Permanente de la Inmigración 2005: 80I-802).

There are no official data concerning renewal figures to date. Through my interviews, however, it seems that the majority of people regularised in 2005 still held this status after a year had elapsed. This is not so surprising when one bears in mind that, unlike what occurred in 2000 , arraigo laboral was more than ever before demonstrated at the time of regularisation. In other words, the conditions of renewal (this time, yes) 
were less taxing than those of regularisation. Nevertheless, according to the General Council of Spanish Lawyers, I5 per cent of those regularised in 2005 had their renewal applications rejected at the end of the year (SOS Racismo 2007: 65). Cachón (2008) estimates that, in October 2006, 8I.6 per cent were still employed while I2.3 per cent were receiving unemployment benefits - which means that around 6 per cent would have had problems renewing their residence permits. Explaining this figure, two lawyers I interviewed observed how renewal was especially difficult for those who had achieved legal status thanks to a 'false' or 'doing-afavour' job. In these cases, since the initial permit was limited to sector and province, the difficulties in finding real employment and notching up the necessary six months of social security payments could certainly mean becoming illegal again at renewal time ${ }^{\mathrm{I} 4}$ (interviews 3I October 2007 and I7 March 2008, Barcelona).

Notable is a clear pattern that was established for the kinds of jobs that engaged regularised foreigners. One year after regularisation, there were more foreigners working in the construction, commerce and hotel and catering sectors and fewer working in agriculture and, in particular, domestic service. To illustrate, while in 2006 , female domestic workers represented 3I.7 per cent of the total foreign women registered as working, in 2007 the figure dropped to 22.I per cent - 60,000 fewer workers (Pajares 2007: 22I). This coincides with what I noted in the previous section: immigrant workers' gradual shifting into economic sectors initially reserved for national or authorised workers. At the same time, this change calls into question of the point to which employers (especially in agriculture and domestic service) were interested in renouncing the advantages they derived from the immobility of their workers because of their illegal status. In other words, how many employers agreed to regularise their workers knowing full well that, after holding the permit for one year, they could move into other sectors? In this regard, one employer remarked: 'Why would I give them papers? The minute I give them papers, they up and leave me!' (in Arango \& Suárez Navaz 2002: 485).

\subsubsection{Permanent regularisation}

The 2005 regularisation, much more than earlier ones, was controversial and subject to criticism both within and outside Spain. Faced with all the dissenting voices, the PSOE government continued to emphasise the inevitability of the process and the need to clamp down on the informal economy. It also kept reiterating, just as it had done in preceding regularisation processes, that this was the last time. The message given out by the government was that, from then on, immigration had to 'be legal', and that anyone who entered the country or who was staying on illegally would be 'returned' (i.e. deported) to his or her country of origin. 
However, no more extraordinary regularisation processes did not mean that there would be no more regularisations. Although the political discourse started to emphasise border control and deportations, nobody counted on these measures as being sufficient to reduce illegal immigration. As the CES had already suggested in its 2004 report, the idea was 'to introduce elements of greater flexibility that would make it possible to respond to specific individual situations where there exists a real and effective link with the job market, while at the same time adopting adequate measures to avoid the so-called "pull effect"' (CES 2004: I39). As an NGO representative noted, the aim was to regularise immigrants "without bringing it to people's attention or giving rise to suspicion in civil society' (interview I2 December 2007, Barcelona).

With this objective, the Reglamento of 2004 again took up the notion of arraigo introduced by LO 4/2000 and subsequently restricted by LO 8/2000. Arraigo social was a means of regularisation for those people who could present the following: proof of having resided in Spain for three years, a crime-free record in Spain and their country of origin, a one-year minimum contract, proof of family ties or a report from the municipal town council of usual residence attesting to the individual's social integration. ${ }^{15}$ Through the notion of arraigo laboral, people who had lived in Spain for two years, had no criminal record and could prove a one-year minimum employment relationship by means of a verdict to the effect, or certificate from the Department of Labour Inspection, could also attain legal status. ${ }^{\mathrm{I}}$ In both instances, authorisation for work and residence has a duration of one year. Although with arraigo social the authorisation is limited to economic activity sector and province corresponding to the available job offer, these restrictions do not apply for authorisation obtained through arraigo laboral because this procedure does not demand the existence of a prospective job offer (but rather proof of a previous employment relationship).

It is important to highlight here the progressive convergence between regularisation policies (including the 2005 process) and entry policies. First, in both cases, the chances of obtaining work and residence permits depend on an employment offer and thus on an employer. In other words, since 2005 , employers have determined not only people's prospects of entering the country, but also of their regularisation. Second, what is possible in terms of economic sector and province is restricted not only for new arrivals, but also for the newly regularised immigrants (via arraigo social). That is, the former and the latter both receive an initial one-year permit that fixes them within a particular sector and province. Nonetheless, the job offer that gives rise to regularisation need not be an 'unsatisfied' offer. To put it slightly differently, unlike the mechanisms that control entry, regularisation does not require a pre- or post-evaluation of job market needs. This means that illegal immigrants who apply for 
regularisation can do so in any economic sector, regardless of whether or not there are national or authorised workers available. ${ }^{17}$ The counterpart of this is that, in regularisation based on arraigo, the immigrant must have spent two or three years living illegally in the country.

Analysing the results of regularisation on the basis of social consolidation or job stability is difficult. It is possible to state that there are very few cases of regularisation being granted on the grounds of the latter. For example, in 2006 only 223 authorisations were conceded (Ministerio de Trabajo y Asuntos Sociales, I3 February 2007). As for the former, doubtlessly the more widely practised form of regularisation, it is impossible to draw any specific conclusions due to the absence of official national-level data, at least at the time of writing this book. ${ }^{\mathrm{I}}{ }^{8}$ In 2006 , the figure for authorisation via arraigo social was 6,6I6 (ibid.). However, this number is not very significant since those excluded from the 2005 process did not satisfy the condition of a three-year minimum residence in Spain until 2007 or $2008 .{ }^{19}$ Hence, it is necessary to analyse data from these two last years to evaluate the magnitude of the phenomenon of regularisation through arraigo social. At the end of 2006, the Immigration Law Practitioners Association of Madrid calculated that the 2007 number of applications for regularisation based on arraigo social could have been as high as somewhere between 400,000 and 600,000 (El País 9 December 2006). Although the figure is debatable, it is certainly possible that it is as high as, or greater than, that for those who achieved legality through the entry mechanisms.

If this is so, the regularisation methods would continue to represent, as they have done since the I990s, the main way of acceding to legal status. Nevertheless, there has been a major change. Until 2004, regularisation processes tended to be taken as separate from the foreigner's employment situation by making (illegal) residence the main requisite for obtaining a permit. In contrast, from 2004 onwards, access to legality has depended on a formal effective integration of the foreign worker on the job market. In other words, only foreign workers with a job are eligible for regularisation. This means, on the one hand, that unlike what was observed up until 2004, regularisation - not the first renewal - is raised as the first barrier to entry. From this, one might deduce that the number of foreigners who lapse back into illegality at the time of renewal has diminished. However, granting legal status only to foreign workers with a job means that, as we saw regarding entry policies, the individual who gets the process underway (and hence governs both chances for regularisation and the characteristics of the immigrants) is, once again, the employer. A question that remains to be answered: if everything depends on labour demands (entry, regularisation and renewal), what are - and what will be - the consequences of the 2007 economic crisis for the legal status of immigrants in Spain? 


\subsection{Deportation from within and from without}

\subsubsection{Constructing migrant deportability}

The first LOE, passed a few months after Spain entered the EEC in I985, aimed to prevent Spain from becoming a transit or 'immigrant sieve' country for people heading for Northern Europe (see section 4.3). The idea was that Spain should fulfil the role of a dependable member of the EEC, serving as scrupulous guardian of Europe's southern frontier, a function it had been implicitly assigned. Then Minister of the Interior José Barrionuevo justified the new law in terms of a need to '[...] endow the Judiciary and the Executive with the necessary legal means whereby to defend Spanish society more effectively from the mafia and other international delinquents' (Spanish Parliament, I9 February I985). In keeping with these aims, the LOE introduced the possibility of detaining illegal immigrants (for 40 days) in institutions known as centros de internamiento de extranjeros ('foreigner internment centres'), besides enshrining expulsion as the only response to illegality. ${ }^{20}$ As pointed out by the aforementioned lawyer interviewed by Suárez-Navaz (I997: 7): 'Basically the message is that if you are "illegal", the state has only one responsibility: to deport you, without your having any chance of appealing such action in court.'

In response to the LOE, different immigrants' associations, NGOs and lawyers' colleges asked the ombudsman to intervene by lodging an appeal with the Constitutional Court. The resulting constitutional ruling (STC II5/I987), besides quashing restrictions that had been imposed on the right of freedom to assemble and associate, rescinded the prohibition against judges being able to suspend deportation orders. It also reinterpreted preventive internment prior to expulsion, accepting the 40 day period though establishing minimum guarantees such as the individual's appearing before a judge in a previous hearing, the right to defence and a ruling stating grounds of detention. Finally, a number of different constitutional decisions eventually restricted the occasions for detaining and deporting illegal immigrants. For example, the constitutional rulings STC 94/I993, STC ir6/ı993 and STC 242/1994 rescinded several expulsion orders on the grounds of violating basic rights of foreigners in Spain. As Aja (2006: 25) points out, although these rulings were based on specific cases, they did have the general effect of ushering in jurisprudence that responded critically to administrative excess.

Apart from the limitations imposed by rule of law, reality also set limits to the binomial of illegality/deportability. If it is true that the number of foreigners detained rose substantially throughout the I990s (from I5,4I6 detentions in 1995 to 40,710 in I998), it is also the case that the number of expulsions actually carried out remained relatively constant at about 4,800 per year (El País I9 April I999). In other words, greater immigrant 
control did not necessarily mean more deportations. The cause of this difference lies precisely in the difficulty entailed in every process of expulsion. First among them is the matter of the high cost this involves..$^{2 I}$ Another difficulty was identification of illegal immigrants' place of origin. Finally, there remained the problem of whether or not it was possible to count on cooperation by authorities in the countries of origin. All these impediments explain why such highly repressive legislation, in which the only response to illegality is expulsion, has not always meant greater actual deportability and why it is precisely in this domain that the state has more readily overstepped the limits of legality.

One example sufficiently illustrates this last point. In I996, José María Aznar, then PP president of the Spanish government, responded to numerous criticisms by declaring: 'There was a problem, and the solution has been found' (El País 2I July I996). The 'problem' was a group of I03 immigrants from sub-Saharan Africa who repeatedly staged demonstrations in front of the Spanish government offices in Melilla (one of the two Spanish enclaves in Morocco) to protest the wretched conditions (including lack of water and food) in the authorised reception centres. The 'solution' was to transport them to a foreigners internment centre in Malaga and then to deport them via five planes to Cameroon, Mali, Senegal and Guinea Bissau. Many of the deportees were sedated for the journey. Moreover, not all were sent back to their countries of origin. Although the operation was conducted in utmost secrecy - according to the Ministry of Interior, to 'prevent knowledge of the operation from getting in the way of agreements with the receptor countries' - it came to light a few days afterwards.

Immediate protests were voiced by the ombudsman, the Unified Police Union, the Spanish Commission for Refugee Aid, Judges for Democracy, unions, NGOs and some political parties. These organisations condemned more than one abuse: the I03 cases were not treated individually (as provided by law), but by collective court orders; the deportees' right to legal assistance was not respected; regulations pertaining to asylum, according to which the request for asylum automatically freezes any deportation procedures, were not observed; sedatives were administered en masse without medical prescription or by court order; and many of the immigrants were deported to third countries because, as the Ministry of Interior admitted some days later, 'the identity and country of origin of the deportee was unknown in many cases' (El País 28 June 1996).

In the face of these protests, Minister of Interior Jaime Mayor Oreja was obliged to appear before the Parliamentary Commission for Justice and the Internal Affairs. In his speech before the commission, which was subsequently analysed by Martín Rojo and Van Dijk (I998), the minister asserted that the expulsion had been carried out 'in strict observance of the stipulations of the LOE' (Spanish Parliament, I996, 44: 848), although he did concede that it had not been 'precisely a model operation' (ibid.: 852). 
On another occasion, the minister described the operation as 'discrete, diplomatic, disagreeable and anti-aesthetic'. In excusing the fact that it had been 'anti-aesthetic' and not exactly a 'model' operation, he alleged concerns for security. On the one hand, the minister stressed that the procedure was not only legal but 'obligatory'. In his own words: 'We must not forget that, in keeping with the stipulations of articles 149 and 104 of the Constitution and article 1 of the Law on the Protection of Citizen Security, the Government is obliged, through its different agencies and State Security Forces and Corps, to protect and guarantee citizen security and to remove any factors that jeopardise it' (ibid.: 848). On the other hand, he trotted out the old bogeyman - the danger and violence of immigrants. While asserting that 'the human rights of the deportees were not violated', the minister was at pains to stress that many of them 'had criminal records' (El País 22 July I996). Along similar lines, one member of the police union declared: 'It is more humanitarian to give the detainee a tranquiliser than to fight with him in order to make him undertake the journey' (ABC 25 July I996).

In the end, all these arguments lead back once more to the famous utterance of President Aznar: 'There was a problem and the solution has been found.' According to SOS Racismo's annual report (I996: 156), these words can be translated as meaning that 'irregular immigration is a problem of public order' and that 'in order to maintain this order, the state has the right to apply any means'. In other words, as an illegal person, the immigrant is deportable whatever the circumstances. The argument runs as follows: when illegal immigration is presented as a threat, national security takes precedence over any obligation of legality. It is precisely then that the illegal immigrant ceases to have rights and is no longer protected by the law. However, as we shall see, this alegalisation - putting the immigrant beyond the reach of the law - is even clearer when he or she is now outside (having been deported) or still outside (not yet having arrived) national territory. This is a zone where rule of law cannot be taken for granted.

\subsubsection{Non-deportable deportees}

Law 4/2000, passed with general consensus of all parties in the Spanish Parliament, unions, immigrants' associations and NGOs, made illegal residence subject to a fine but not to expulsion. This represented a major change of political direction: regularisation and not expulsion was to be the basic mechanism for combating illegality. Yet, as we saw in section 4.3, the policy change lasted only a few months. With the PP's absolute majority in Parliament (after the March 2000 elections) and the passing of new Law $8 / 2000$, the penalty of expulsion was reinstated for illegality in residence and/or work. ${ }^{22}$ The reasons adduced essentially boiled down to two: to control illegal migration and to comply with European standards. 
To cite Mayor Oreja speaking in Parliament as Minister of Interior: 'With this measure, ladies and gentlemen, the aim is to boost a certain capacity for state action with regard to controlling illegal immigration. The countries of the European Union have constitutional means for expelling foreigners in this situation. The Tampere European Council reached its conclusions according to similar criteria and there is no reason why Spain should not have the same legal instrument as the other countries of the European Union' (Spanish Parliament, 5 October 2000).

As already noted, to carry out an order of expulsion, the illegal immigrant's country of origin must be known and consent of its government must be obtained. The Spanish government has 40 days to meet these two conditions, during which period the illegal immigrant can be held in an internment centre. ${ }^{23}$ If not met within the timeframe, the government cannot prolong the detention and the immigrant is hence freed after having received an expulsion order. This is what happens in the majority of cases. For example, of the II7, 768 expulsion orders issued between January 2002 and July 2004 , only 32,749 (27.8 per cent) were carried out (SOS Racismo 2005: II6). It is estimated that between $200 \mathrm{I}$ and 2005, some 122,000 immigrants remained in Spain despite their having received an expulsion order (Silveira Gorski 2006: 5). More recently, of the 48,857 and 45,7I4 expulsion orders respectively issued in 2006 and 2007 , only II,373 (23 per cent) and 9,53 $6^{24}$ (20.8 per cent) were carried out (Diario Vasco 9 May 2008). This means that, in recent years, only one in every five illegal immigrants who received an expulsion order was actually deported. This directly leads us to ask: what happened to those immigrants who received a deportation order but were not deported or, more to the point, not deportable?

For the greater part, the expulsion order meant that regularisation was no longer possible. In other words, the immigrant with a deportation order who was not actually deportable was not regularisable. Hence, we have a legal figure - the undeportable, unregularisable deportee - characterised by administrative liminality. Illegal immigrants are thus recognised yet kept partially and indefinitely beyond the pale. As expressed by one NGO lawyer interviewed in Barcelona (I8 December 2007): 'It's outrageous! It's illogical! They bring in an order of expulsion that obstructs regularisation. Regularisation by way of stipulated period of residence requires three years of illegal residence, and yet illegal residence can be penalised by an expulsion order. This is a contradiction!' Accepting an idea from the Comisión Española de Ayuda al Refugiado (Spanish Commission for Refugee Aid, CEAR), the ombudsman proposed furnishing illegal immigrants with a document that would provide a form of identity check and enable engagement in some kind of employment for as long as their deportation order could not be fulfilled. The Department of Immigration was swift to reject the proposal, arguing that this practice 'could end up being a stimulus to the 
activities of illegal networks of human trafficking' and that it would bring about a situation of 'legal uncertainty' by turning illegal immigrants into resident workers pending deportation (in El País 24 September 2007).

In fact, among the non-deportable deportee immigrants, the only ones who managed to become regularised were those whose expulsion order was previously revoked by a lawyer. This was feasible in situations where the immigrant had immediate family members (a parent, child or spouse) legally residing in Spain and a formal job offer. However, after the beginning of 2008, some government sub-branches, in Madrid and Barcelona, for example, officially began to revoke expulsion orders of those who were initiating a process of regularisation on the basis of arraigo (see section 4.6.8). The logic of this, according to a sub-branch representative, was that 'Very few deportation orders are carried out. Since we can't do all of them, priority must be established. It's necessary to start with people who've broken the law or who are in a situation of extreme marginalisation. Before letting in more people from outside, the ones that are already here have to be regularised. But this can't be talked about too much because otherwise you get the pull effect' (interview 2I April 2008, Barcelona).

This new possibility of rescinding the expulsion order in the case of regularisation means that immigrants who have received an expulsion order are still deportees in legal terms (although non-deportable in practice) until they meet the conditions required for regularisation. In particular, this means that the immigrant's status as 'non-deportable deportee' lasts until he or she can demonstrate three years of illegal residence and a certain degree of integration in the social and working spheres (with a one-year minimum job contract). This has two major implications with regard to the legal definition of illegality. First, while the immigrant remains illegal, being legally 'expelled' heightens the sensation of imminent deportability and thus the fear associated with this. As a representative of the Moroccan Workers' Association in Catalonia (ATIMCA) noted: 'Illegal immigrants circulate normally, like everyone else. They know they won't be directly repatriated. But, yes, with an expulsion order they are scared' (interview 6 February 2008, Barcelona). Second, the possibility of regularisation after administrative expulsion brings to light different, contradictory dimensions constituting illegality. Apart from the figure of the non-deportable deportee immigrant who is not regularisable, emerges that of the non-deportable deportee immigrant who is regularisable after three years of illegal residence and proven integration in the social and working domains.

To these figures must be added another two. As Sagarra (2002) points out, there is that of the illegal immigrant who appears in el Padrón and is thereby a documented resident (at the local level) with access to minimal social services (health and education) and that of the illegal immigrant worker. Taken together, the figures exemplify yet again the contradictions 
inherent in the legal definition of illegality in Spain. On the one hand, when they appear in the municipal registry, illegal immigrants are recognised as 'documented' residents with some protection of their civil rights. On the other hand, being illegal workers in the informal economy (with much lower salaries and lacking social security cover in case of illness or unemployment), their presence is not recognised as workers. Thus, while some of their social rights are honoured, they are denied workers' rights in practice. The dimension of work, along with deportability, is what most distinctly colours their illegal status in terms of being outsiders or 'others'. The category of the legally expelled illegal immigrant who is not actually expellable but is registered in the municipality and working does not last forever. This is essentially because, since early 2008 , immigrants have become regularisable after the stipulated period of time has elapsed. Nevertheless, as long as this category persists, it constructs 'quasimembers' of the community while simultaneously reducing them to being deportable - yet mostly not deported - labour.

\subsubsection{Rejected at the border}

While deportation from inside the country's territory is convoluted to the point of producing the figure of the legally deported immigrant who is actually non-deportable, rejection at the border is another story. It is much easier because it does not require another government's willingness to return the person to the country of departure. Accordingly, if within the territory only one in every five immigrants with an expulsion order is in fact deported, the ratio of those turned back at the border soars up to nine out of ten. In 2007, of the 50,318 people detained at the border, 46,47I (92 per cent) were repatriated (El País 9 January 2008). Of these, 24,355 were denied entry on grounds of non-admission at official border posts (mainly airports and shipping ports), while 22,II 6 were rejected (i.e. turned back, what is called in Spanish devolución) after being detained when they tried to cross the border illegally (see Table 4.8).

Deportation by non-admission (what is called in Spanish denegación) is applied in the cases of migrants who are about to enter through legitimate channels but are deemed inadmissible by immigration officers. The majority is rejected because they are suspected of intending to overstay their visa. Others are because they arrive without valid documents, with forged documents or because they are unable to demonstrate sufficient financial means. The non-admission file is opened after two interviews (the second usually in the presence of a lawyer) where the traveller is interrogated about reasons for the journey, documents, means of support and contacts in Spain. The conditions for non-admission are regulated by law. To enter Spain as a tourist in 2008 it was necessary to have sufficient funds ( $€ 6 \circ$ per day and a minimum total sum of $€ 540$ ), a hotel reservation 
(pre-paid, if possible) or a letter of invitation, a fixed booking for the return flight, knowledge about what he or she wished to see as a tourist and how to get from the airport to the hotel. Apart from these indicators, a lawyer from the Barcelona College of Lawyers pointed out other matters also playing an essential role when it comes to being granted entry or not. In her words: 'If you see that their hands are covered in calluses, you know they're not coming in as tourists!' (interview 8 April 2008, Barcelona). In short, physical appearance (with evident race and class connotations) would seem to be decisive in distinguishing alleged 'tourists' from alleged 'economic immigrants'.

Table 4.8 Repatriation of illegal migrants in absolute numbers and row percentages, 2000-2007

\begin{tabular}{llllll}
\hline Year & $\begin{array}{l}\text { Expulsion } \\
\text { orders } \\
\text { (carried out) }\end{array}$ & $\begin{array}{l}\text { Non-admission } \\
\text { (denegaciones) }\end{array}$ & $\begin{array}{l}\text { Turned back } \\
\text { (devoluciones) }\end{array}$ & Readmissions & Total \\
\hline 2000 & $\begin{array}{l}(6,579) \\
18.5 \%\end{array}$ & $\begin{array}{l}6,181 \\
17.4 \%\end{array}$ & $\begin{array}{l}22,716 \\
64 \%\end{array}$ & $\mathrm{NA}$ & 35,476 \\
2001 & $(12,976)$ & 8,881 & 22,984 & $\mathrm{NA}$ & $\mathbf{1 0 0 \%}$ \\
& $28.9 \%$ & $19.8 \%$ & $51.2 \%$ & 44,841 \\
2003 & $(14,104)$ & 14,750 & 13,684 & 50,407 & $100 \%$ \\
& $15.1 \%$ & $15.8 \%$ & $14.7 \%$ & $54.2 \%$ & $100 \%$ \\
2004 & $(13,296)$ & 11,280 & 13,136 & 83,431 & 121,143 \\
& $10.9 \%$ & $9.3 \%$ & $10.8 \%$ & $68.8 \%$ & $100 \%$ \\
2005 & $(11,002)$ & 15,258 & 14,466 & 52,017 & 92,743 \\
& $11.8 \%$ & $16.4 \%$ & $15.5 \%$ & $56 \%$ & $100 \%$ \\
2006 & $48,857(7,214)$ & 19,332 & 26,652 & 46,247 & 99,445 \\
& $7.2 \%$ & $19.4 \%$ & $26.8 \%$ & $46 \%$ & $100 \%$ \\
2007 & $45,714(9,467)$ & 24,355 & 15,868 & $6,248 * * \%$ & 55,938 \\
& $16.9 \%$ & $43.5 \%$ & $28.3 \%$ & $11.1 \%$ & $100 \%$ \\
2008 & $(10,616)$ & 17,317 & 12,315 & 6,178 & 46,426 \\
& $22.8 \%$ & $37.3 \%$ & $26.5 \%$ & $13.3 \%$ & $100 \%$ \\
\hline
\end{tabular}

* Reduction from prior year is explained by some people sent back appearing under readmission after 2003.

*** Reduction from prior year is due to Romanians and Bulgarians becoming European citizens as of 1 January 2007.

Source: Ministry of Interior (2000-2008)

For immigrants coming from afar - which is to say, those whose entry is only feasible via an official border post (mainly airports) - non-admission means not only immediate return of the immigrant to the country of origin (for which the airline or other transport company is responsible), but his or her passport is also marked with a crossed-out entry stamp so 
that return will be difficult. As the above-cited lawyer notes, non-admission is, for many would-be immigrants, the end of the line: 'The most dramatic thing is non-admission. Their hopes, which are personal and family-related, are frustrated. You know that an expulsion file isn't going to affect the person's life. It can be revoked with regularisation on the basis of duration of residence in the country. But non-admission puts an end to the migratory project. This is devastating' (interview 8 April 2008, Barcelona). Despite the fact that the extension of visa requirements to such countries as Peru (200I), Colombia (2002), Ecuador (2003) and Bolivia (2007) has displaced migratory control to the countries of origin, the numbers of people rejected on grounds of non-admission have swelled considerably in recent years (for example, 26 per cent between 2006 and 2007, as shown in Table 4.8). This suggests the increasing significance of a double filter: before departure (for those citizens for whom a visa is required) and at point of entry (especially those citizens for whom a prior visa is not required).

Besides those rejected at the point of entry, deportation is also applied in cases of those who are detained for trying to enter the country illegally. On the one hand, as with non-admission, this is a police measure requiring immediate response. It is therefore a procedure wherein civil rights are respected much less than a process initiated when expulsion orders are issued for immigrants already in the country. On the other hand, unlike non-admission, and like the expulsion order, being turned back involves deportation as well as prohibition of entry for a three-year period. As shown in Table 4.8, the numbers of people turned back (including readmissions or, in other words, those sent back under a readmission agreement) were particularly high between 2003 and 2006 . In the latter year, the numbers turned back at the border represented 73.3 per cent of the total of repatriations (including expulsion and non-admission).

While illegal entry is almost invariably associated with the EU's southern frontier, the fact is that most people have been turned back at the border with France. This is noteworthy for a number of different reasons. First, it is a very different matter from the picture concocted by the mass media. It is in the Pyrenees Mountains - not the Strait of Gibraltar or the waters between Africa and the Canary Islands - where most detentions and deportations have been carried out. Second, this is an internal EU frontier - which is to say, a border that is open to EU citizens and selectively restrictive for those who are not. Third, the fact that the deportations have been carried out at this border rather than the southern frontier also explains the drop in numbers turned back after 2007. The reason is simple: after 2007 most people deported in earlier years (Romanians and Bulgarians) were now EU citizens. ${ }^{25}$ Finally, it is also interesting because it is here that a bilateral treaty of readmission was applied for the first time.

The readmission treaty between Spain and France was signed in 2002. 
Article 5 establishes that '[...] each contracting party will readmit into its territory, at the request of the other contracting party, without any kind offormal procedure, the national of a third state who does not comply with, or who has ceased to comply with the conditions of entry' (BOE, 2003). The process of turning back the immigrant is greatly expedited because it can now occur 'without any kind of formal procedure', being put into effect immediately without needing to abide by procedural formalities. People have thus been turned back without any form of legal assistance. Despite protests by the different colleges of lawyers and a court decision stipulating that the right of the 'returnee' to effective legal assistance was to be respected, the Spanish government has always responded in the same way: since wouldbe immigrants are returned under the heading of 'readmission' and not 'turned back', the bilateral agreement applies. At the border, then, the bilateral agreement takes precedence over the LOE, which requires observance of the right to legal assistance in all cases.

The readmission agreement that Spain signed with Morocco in 1992 was reactivated in 2004 along the lines of the experience with France. According to what was stipulated therein, Morocco undertook readmitting into its territory all those immigrants who had entered Spain illegally from Morocco, regardless of their nationality. While the repatriation of Moroccan citizens began with the signing of the I992 agreement, the return of citizens of third countries was systematically rejected by Moroccan authorities on the grounds of insufficient evidence to have come through Morocco. For example, from I999 to 2004, the Moroccan government rejected all 6,420 requests from the Spanish government for readmission of citizens from third countries (Ministerio de Interior 2006). After 2004, with the change of government from PP to PSOE, improved bilateral relations between the two countries led to cautious renewal of the readmission of citizens from third countries. The number of repatriations to Morocco has been rising since 2006 , when readmission of illegal immigrants (Moroccans and people from third countries) was linked to other bilateral arrangements (in spheres such as agriculture, industry and services) and development aid.

Deportations to Morocco have caused concern and unremitting protest. In 2006 , leading Spanish newspapers denounced the immediate, forcible turning back of illegal immigrants from the Spanish enclaves of Ceuta and Melilla, citing violation of all the procedures established by the Law on Foreigners. One member of the Civil Guard was quoted declaring: 'We follow orders from the top, even though we all know they are against the law' ( $A B C 5$ October 2006). The newspaper El País reproduced a recording of another Civil Guard member ordering: 'If the fence can be opened and they can be rejected, then get them out!' (El País 6 October 2006). Protests about the practices of detention and repatriation carried out in Moroccan territory have had a twofold aim: criticising the Moroccan government for vi- 
olating immigrants' human rights and censuring the Spanish government and the EU for externalising immigration control.

\subsubsection{Beyond national borders}

Since 2006 , the new mainstays of Spanish policy for controlling migratory flows have been, first, fostering migration controls in the countries of origin and transit and, second, facilitating the repatriation of illegal immigrants. Border control in countries of origin and transit, as Minister of Interior Alfredo Pérez Rubalcaba has indicated, was urged to ensure '[...] that the boats do not get far from their points of departure, or that they are intercepted as soon as possible because, otherwise, not only will the danger of loss of human life be higher but also those people who survive will enter our territory and it then will be necessary to initiate the complicated, difficult and expensive procedures of repatriation' (Pérez Rubalcaba 2008: 76). The repatriation policy has attempted to ease the way for the swiftest possible return of those who, despite all the dangers and obstacles, manage to reach Spain. In particular, it aims to ensure that this will occur before the maximum period of detention (40 days) in the internment centres has expired. In both cases, the policies require cooperation from third countries. Hence, the so-called Africa Plan (2006-2008).

The Africa Plan was justified as a reorientation of priorities of Spanish foreign policy with the aim of establishing a deeper, more encompassing framework for relations with sub-Saharan Africa. The plan had seven goals: I) Spanish participation in the bolstering of democracy, peace and security in Africa; 2) Spanish contribution to the struggle against poverty and the development agenda in sub-Saharan Africa; 3) promoting cooperation with African countries in regulating migratory flows; 4) active participation in the EU strategy for Africa; 5) promotion of trade and investment exchanges, with particular attention to fishing grounds and energy security; 6) reinforcement of cultural and scientific cooperation; and 7) strengthening Spanish political and institutional presence in Africa. Whatever the general presentation of the plan suggests, the most specific measures involved are aimed at shoring up the two new lines in Spanish policy for the control of migratory flows - which is to say, migratory control in the countries of origin or transit and repatriation of illegal immigrants.

This emphasis on migration control and its being tied to development assistance was immediately criticised. To illustrate, the NGO Intermon Oxfam noted: 'On analysing the Africa Plan, one wonders if this is a Spanish plan for Africa or a Spanish plan in Africa.' It concluded: 'The use of development assistance as payment in return for the African countries putting up fences, tightening up migrant controls or accepting the repatriation of emigrants is a perversion of development assistance and, as such, unacceptable' (in Aso- 
ciación Pro Derechos Humanos de Andalucía 2007: I4-I5). In fact, the Spanish government never denied that this was essentially a tit-for-tat arrangement: greater migratory control (by the African countries) in exchange for greater development assistance (from Spain). The Secretary of State for Foreign Affairs said it loud and clear: 'The new-generation agreement on immigration will make development assistance conditional on the struggle against flows of illegal immigrants and agreement to the repatriation of undocumented persons' (in Asociación Pro Derechos Humanos de Andalucía 2006: I5). The countries of origin were no less aware of the deal's conditions: Spain would let in more legal immigrants (see section 4.4.3), offer wells (or other forms of development assistance) and cancel debts in exchange for their cooperation in border monitoring and agreeing to the return of illegal immigrants.

This new direction in Spanish foreign policy has led to the signing, since 2006 , of a series of bilateral agreements with Senegal, Mali, Ghana, Cameroon, Ivory Coast, Cape Verde, Guinea-Conakry and Gambia. These agreements have made it possible, on the one hand, to displace migratory control beyond the Spanish border by shifting the focus of this control more to blocking exit than preventing entry. On the other hand, they have offered the possibility of repatriating illegal immigrants trying to enter from sub-Saharan Africa. Nevertheless, the repatriation measures do not seem to have resulted in a numerically significant response to illegal immigration (see Table 4.8). Among many other factors, the economic cost of repatriation has been a major impediment. Political costs for the governments of readmission countries have also meant restrictions on repatriation being put into practice. ${ }^{26}$ Accordingly, although it is perhaps premature to jump to such conclusions, it would seem that these agreements have ended up working more as agreements on border monitoring and control than readmission agreements (see López Sala 2010). Confirmation of this trend would mean that the agreements have mainly resulted in externalisation and subcontracting of control, detention, internment and repatriation of would-be immigrants.

If deportation measures have often been carried out on the border with only a bare minimum of legal guarantees and civil rights observance, on the far side of the border there is no such protection worthy of the name. Accordingly, it is here where detention and deportation are carried out with greater impunity. Morocco is a case in point. In 2006 , social organisations and human rights campaigners protested the deportation of subSaharan migrants to the Algerian border. They denounced the fact that somewhere between I,००० and I,200 immigrants had been dumped in the desert without food or water. In 2008, Amnesty International denounced the living conditions and human rights violations in a detention camp in Mauritania (known as Guantanamito for 'little Guantanamo'). Rebuilt by Spanish authorities, this camp fulfilled the function of receiv- 
ing and retaining until repatriation those emigrants who had attempted to leave Mauritania for Spain. These two examples make it clear how detention, retention and repatriation tend to be less 'complicated' and less 'difficult' when they occur beyond Spanish borders. The reason is simple: in this geographical and legal 'beyond', the state finally escapes legal, judicial and often, though not always, civil society checks. It is in this space where the status of illegality is melds most with the situation of a-legality.

New migration policy that emerged from the Africa Plan and its resulting bilateral treaties were presented by the government as a great achievement, justifying this claim by the effect the policy has had on the migratory influx. While it is difficult to establish a cause-effect relationship - and, since 2008, the economic crisis' effects must be kept in mind it would appear that greater control at the point of exit has had the effect of reducing the number of arrivals. Second, the Spanish government has touted itself as the driving force behind new immigration policy at the European level. This has particularly relevant connotations if we recall that, until today, Spain had tried to comply with EU demands more than to define their content. In other words, if the EU had previously influenced Spanish policy, Spain seemed now to influence the definition of EU policy (see e.g. Rubalcaba 2008: 74; Zapata-Barrero \& De Witte 2007: 89).

\subsection{Final remarks}

Since the I990s, Spain, historically a country of emigration, has become a country of immigration. Apart from the push factors that led many of the immigrants to leave their countries, there is one very clear reason for this influx: throughout the I990s and particularly from 2000 to 2007 , Spain had an 'insatiable hunger' for immigrant workers. The first question to consider is how the state responded to these heavy demands for foreign labour and, more specifically, how it regulated the entry and stay of the allegedly demanded-for workers. A review of immigration policy would seem to offer a clear answer to this question. Until 2005, the state responded with an entry policy that was highly restrictive. First, this was how it appeared on paper, which was the result of keeping with EEC-imposed guidelines: the LOE I985 was promulgated to block entry to immigrants en route to Western European countries via Spain. Second, the policy was restrictive in actual practice. As we have seen, there are several reasons for this: entry was long subject to a very strict evaluation of the job market; entry has always been contingent on a prior job offer, which was often difficult to ascertain without already being in Spain; and, finally, the administrative machinery being unable to handle the situation made legal entry an excessively long and complicated process.

This restrictive entry policy did not mean, however, that low numbers 
of immigrants were entering Spain. Due to high demand for foreign workers, the immigrants were coming into the country and staying. The difference was that since they could not enter legally, they did so illegally. Until 2005, the most common tactic was to come in on a tourist visa, remain, look for a job and then, with the very-necessary job offer now in hand, become regularised, either through the frequent regularisation drives or through official channels for gaining entry to the country that would then be used as though the immigrant worker were still in his or her country of origin. In fact, this is not so different from what occurred in most of Western Europe during the ig6os. Although, at the time, many of these countries had opened up legal channels for entry (via the welltried guestworker programmes), many immigrants, including a large number from Spain, arrived separate from the scheme, found work and subsequently legalised their situation (Groenendijk \& Hampsink I995: I). While they were then perceived as 'spontaneous immigrants', people doing the same thing in recent years in Spain have come to be deemed 'illegal immigrants'. While the immigrants of the ig 60 s actually had legal channels available to them, in Spain the 'illegal' - or 'spontaneous' - option was, up until 2005 , the only one.

In contrast with Western Europe, legal entry into Spain (as an immigrant worker) was for a long time more a juridical fiction than a reality. This mismatch between legality and reality - between a particularly restrictive policy and a reality notable for large numbers of people entering the country - made it possible to comply simultaneously with two sets of claims. There were commands for closure by the EU as well as the trade unions, who did not look kindly on the entry of new workers into a job market characterised by high unemployment figures, and there were the insatiable demands of employers for foreign workers. The mismatch brought about a veritable model of illegal immigration. In the long term, however, this model has not been sustainable. First, illegal immigration could not continue in an unlimited, indefinite fashion without calling into question the legitimacy of the state in its role of controlling migration flows. Second, illegal workers have frequently been perceived as a threat to the wages and working conditions of legally employed workers. Hence, the very same reasons compelling the unions to limit entry simultaneously led them to demand legal recognition for those immigrants already working. Third and finally, not only did the legal process, but also its surrounding politics, bring about recognition of the illegal immigrants to such a progressive extent that the state could no longer go on ignoring their presence.

For all these reasons, this model of illegal immigration gave rise to the need to carry out periodical regularisation drives and attempts to direct immigration through legal channels. The former response has frequently been interpreted (especially by politicians) as the best illustration of the 
'failure' of immigration policies and, more generally, the state's loss of control. Nevertheless, as this chapter showed, regularisation in the Spanish case should be understood primarily as a de facto entry policy. Seen from this perspective, the regularisation drives then appear as a measure that sought to reconcile contradictory demands. The end result has been deferred 'entry' - since the condition for every regularisation is a period of illegal status - of however many immigrant workers were required by the employers. In specific terms, it makes feasible the aforementioned situation whereby immigrants enter the country, look for work and, once they have a job, stay. As González-Enríquez (2009) has noted, this is nothing more than a cheap recruitment model in the place of destination. It is cheap in two ways. First, the costs and risks of the migratory process are shouldered by the immigrant. Second, in political terms it is possible to have a high-numbers policy without putting it in writing and thus without needing to justify it.

With regard to the need for legal channelling of immigration, entry policies after $2005 \mathrm{do}$, in fact, seem conducive to this. There appeared to be no other alternatives at the time. If control over migration flows was the aim, entry had to be opened up. However, for all the political volition and rhetoric, administrative procedures for legal entry have continued to be slow (frequently taking over a year), while job recruitment in the country of origin has proven to be more myth than reality. This, as we have seen, has raised doubt as to what extent the authorised forms of entry have functioned exclusively to channel demands for immigrant workers or whether, and/or in addition, they also respond to demands by friends and relatives of those immigrants who are already in Spain. While a sociological perspective would suggest that migratory processes always arise from different sets of factors, this combination of demands has aroused suspicion among politicians and civil servants. The bottom-line of the misgivings is always the same: What if they're coming more because they already have a social network in Spain rather than because there's a specific demand for labour? Such reservations highlight the great fallacy on which immigration policies in Spain have been based: that immigration is and must be an exclusively work-related phenomenon.

Now that the development of immigration policies in Spain has been outlined, the next issue to consider is the relationship between markets, citizenship and rights. Although both points will be analysed in greater depth and in comparative terms in following chapters, I should like to advance a couple of points here. Taken as a whole, Spain shows how, despite what the laws and policies establish on paper, the market is what has actually determined the numbers of people coming in. As many immigrants as have been demanded for by employers have entered the country. This means that, while migration policy in both formulation and implementation seemed to be responding to demands for closure, if we 
take policy effects and the combination of different related measures (such as regularisation programmes) into account, it would seem that, in the end, the market rules the day.

This does not mean that the demands for closure (which I have called the exclusive dimension of citizenship) have not played an important role as well. In effect, they brought about restriction of legal entry, thereby making illegal entry the only alternative. In practice, the incoming immigrants arrived with very few rights. This situation of illegality, product of a restrictive entry policy, had significant effects on the early years of immigrants in Spain. Furthermore, the demands for closure have also meant that legal residence in Spain is a conditional status during the first five years. As we have seen, renewal of work and residence permits (at the end of the first, third and fifth years) depended on effective and formal integration into the labour market. Again, legal immigrants can lose their status (and hence their rights) in the first five years. Relapse into illegality of those unable to renew their documents is, in fact, a decisive feature that explains much about the Spanish model of illegal immigration. All of these matters lead one to conclude that the demands for closure have not limited entry, though have restricted access to membership of legal and illegal immigrants in the early years after arrival.

What role have rights played? To what point has their role been as decisive as that observed by many Western scholars in other liberal democracies? In general terms, rights (through the legal system as well as the political process) have imposed two major limitations on policy. First, they have introduced a time constraint: even while the rights of immigrants were curtailed in the early years (because of their illegality and, subsequently, conditional legality), they could not remain so in the long term. Over the years, the majority of long-term immigrants has managed to obtain permanent resident status and, in the end, Spanish citizenship. In other words, they stayed on and were finally recognised as fully fledged citizens with all the rights that status entails. Second, rights constraints have introduced a geographic factor also reining in policy: the inability of completely excluding the illegal immigrant once he or she has entered the country. As we have seen, the illegal immigrant is documented at the local level and has access to basic social services (health and education) along with regularisation after three years. Moreover, deportation from within is particularly difficult. In contrast with those who are physically inside the country, it is much easier to detain, intern and deport those who are on the frontier or beyond it. The reason is simple: from this geographic 'beyond', a legal 'beyond' - a space of a-legality - has been constructed where everything (or almost everything) seems possible. If Europe exerted an influence on Spanish immigration policy in its beginnings, with this policy based on the 'beyond', Spain now seems to lead recent European thinking. 


\section{Comparative perspective}

\subsection{Towards closure}

Until the I980s, demands forclosurewere somewhatweakin both Malaysia and Spain. This means, in particular, that the distinction between citizens and foreigners - the legal barriers to entry and membership - were rather blurred. The paths that led to this situation were, however, different. Malaysia had a colonial past in which immigrant workers (from China and India) were perceived as 'birds of passage' or sojourners. After independence in I957, many of these 'eternal foreigners' finally obtained Malaysian citizenship. Yet, this did not make them complete insiders since the distinction between bumiputera (literally meaning 'sons of the soil', which includes Malay and other indigenous peoples) and non-bumiputera (basically Malaysian citizens of Chinese and Indian origins) continued defining different statuses. This division, along lines of ethnic origin, between some citizens and others, also determined immigration policies (see section 3.3). While entry was restricted for Chinese and Indians (including relatives of Malaysian citizens), Indonesians (insofar as they were ethnically Malay) were not always categorised as foreigners and hence enjoyed free entry to Malaysia and its labour market over a long period of time.

In contrast with Malaysia, Spain was originally a country of emigration and also perceived as such. Accordingly, until the I980s, policy was essentially geared towards emigration - which is to say, defining, channelling, selecting and keeping track of the numbers of people leaving the country. Meanwhile, immigration policies were notable for their randomness and general irrelevance. Barriers to entry and stay were minimal because the numbers of immigrants coming into Spain to stay were also minimal. This absence of legal obstacles was still more pronounced for citizens of former Spanish colonies. For example, in 1968, when holding a work permit was introduced as the necessary condition for working legally in Spain, foreigners from Latin America and the Philippines were exempted. The citizenship law is another example of how the frontiers were more permeable for some than for others. Unlike other foreigners, South Americans, Filipinos and Sephardic Jews could and this is still the case - apply for citizenship after two years of legal residence. 
In Malaysia, ethnicity closed doors for some and opened them for others. In Spain, cultural or historic proximity facilitated entry and inclusion in a world that was already relatively open. If we now analyse how policies actually worked, the picture is not so different. Until the end of the r980s, illegality was practically a non-issue. This is not to say it did not exist, but simply that it was not perceived as problematic. While in Spain this normalised illegality made the legal borders still more lax, in Malaysia, the de facto porosity reinforced the ethnic bias of immigration policy. This occurred fundamentally because most illegal immigrants were Indonesian and they ended up receiving (legally or illegally) permanent residence status within two or three years of entry and some even within months. As a result, most of the Indonesian immigrants who (legally or illegally) arrived in Malaysia before the I990s were able to stay on. This also meant that their children not only obtained Malaysian citizenship but also, unlike Malaysian citizens of Chinese and Indian descent, were recognised as privileged citizens, bumiputera.

Throughout the ig8os, however, doors prior open for entry and membership began to close for everyone. Illegality became grounds for exclusion and deportation. This gradual, generalised closing of borders which we might call a gradual path 'towards closure' - occurred simultaneously in Malaysia and Spain. The original reasons invoked were different. In Malaysia, the demand for channelling, rather than stopping, labour immigration arose when (mostly Indonesian) migrants began to move to urban areas and, more specifically, to those economic sectors reserved for local (particularly Malay) workers. It was thus the demand to protect the national labour market that ultimately displaced ethnicity as a component of migration policies and their implementation. In Spain, the first demands for closure preceded the arrival of immigrants. In fact, it was Spain's entry into the European Community that led it to regulate the entry and stay of foreigners. This means that restrictive policies were not introduced to control migration flows resulting from increasing labour demands, but represented an attempt to ensure, under EU pressure, that Spain would not become a transit country for migrants to Western Europe.

In the I990s, the demand for closure intensified in both countries. In Malaysia, it continued to be associated with protecting national workers. Although it had always been one of the most conspicuous requirements of Malaysian unions, it was also inextricably entangled with the raison d'être of the state of Malaysia itself. Basically, the increasing presence of immigrant workers was starting to be seen as a threat to state programmes aiming to restructure the colonial society - which is to say, to promote the Malays socio-economically vis-à-vis Chinese and Indians. After 2002, the demand for lessening dependence on Indonesian immigrants (along with their mere presence) was added to that of protecting the national labour market. The Malaysian government argued at the time that the existence 
of Indonesian migrants in the country represented a threat to national security and that, accordingly, they had to be replaced by immigrant workers of other nationalities. This shift in the position and perception of Indonesian immigrants in Malaysia, who went from being potential bumiputera citizens to a threat to national security, is incomprehensible if one does not take into account the context of a general change in nationalist discourse. Until the I980s, the 'national' was defined in ethnic terms (which included many Indonesians inasmuch as they were putative Malays) but, throughout the I990s, it progressively came to be defined in relation with national territory (which automatically turned Indonesians into foreigners or outsiders).

In Spain, the demand for closure continued to be determined by pressure from the EU. This should be understood not only as arising from the fact that Spain was now a member state (after I986), but also as a result of its new role as guardian of Europe's southern frontier. In particular, Spain's ratification of the Convention implementing the Schengen Agreement (1993) and the two subsequent European treaties (Amsterdam and Maastricht) led to an expansion of its border infrastructure and more restrictive entry policies. It is not sufficient, however, to believe that the demand for closure came exclusively from outside. Throughout the I990s, as the numbers of immigrants kept increasing, protection of national workers was another reason for closure. Spanish trade unions have systematically wielded this argument. Nevertheless, as in the case of Malaysia, they were not alone. In Spain, too, the legitimacy of the Spanish state depended in great part on its ability to guarantee this protection. While in Malaysia it was a matter of protecting the state-planned, socio-economic advance of Malays, in Spain the motive was keeping the doors closed in the face of persistent high unemployment figures. In both countries, the official argument has been that of giving priority to the national worker over the foreigner. In other words, as long as there were national workers without jobs - or wanting to work permitting the contracting of foreign workers was deemed unjustified.

These demands for closure had the effect of building up border controls and a progressive hardening of the dividing line between citizens and foreigners. Exemplifying this intensifying closure was the position of Indonesians in Malaysia and of South Americans in Spain. Each group ceased to have the status of quasi-membership in the community and gradually took on outsider status. However, the process of exclusion was different in the two countries. In Malaysia, closure occurred in relation to access to membership rather than entry to the country. In other words, immigration policy did not restrict the entry of immigrant workers, though it did limit period of residence, immobilise their presence in the labour market and pare back rights (for example, of association, family reunification and medical attention). In this regard, Malaysia is the perfect 
example of a policy of high numbers and low rights. Letting immigrant workers come into the country while limiting their presence and membership, Malaysia thus seemed able to reconcile the demands for foreign labour with those for closure.

Unlike Malaysia, closure in Spain occurred mainly at the point of entry or, in other words, in relation to legal access to the country. Until 2005, the entry of immigrant workers was subjected to strict evaluation of the situation of the labour market. The result was particularly low numbers of people coming into the country legally. This low-numbers policy was not accompanied by any policy of high levels of rights. While immigrants in Spain have never been subject to restrictions to the extent they are in Malaysia, in Spain they were also received and recognised in their capacity of immigrant labourers. The temporary nature of residence permits, which depended in the first five years on effective and formal integration in the labour market, meant that their membership was conditional and, in the numerous cases of lapsing into illegal status, variable. In this sense, we might conclude that the situation in Spain has long been characterised by low numbers and conditioned rights. Unlike in Malaysia, this policy that is restrictive with regard to entry, and partially so in the case of membership, highlights how demands for closure were apparently given priority over demands for foreign labour.

\subsection{The market response}

Both the Malaysian and Spanish states opted for some degree of restriction. In both countries, the demands for closure were too weighty to be ignored. The requirement in both countries to protect the national labour market was not just a claim from the unions; the very legitimacy of the state depended on it. Nevertheless, as just noted, the forms the closure took were different. In Malaysia, access to membership was restricted. This means that immigrants could keep entering the country to cover the demand for foreign labour but, once they had come in, their stay was strictly controlled. In the Spanish case, entry was restricted and so too was membership, at least in temporal terms. Unlike Malaysia, the Spanish markets thus had only limited access to foreign labour. A question that then arises is: how did these policies actually function? Namely, how did the Malaysian policy of relatively 'open entry' work, and to what extent were membership limitations fitted to market demands? As for Spain, how did the policy of relatively 'closed borders' work, and what were its effects in view of the major demand for foreign labour? What was the markets' response to the difficulty of legally gaining access to foreign labour?

Entry policies in Malaysia have always sought to delimit the number and profile of foreign workers in keeping with specific (and variable) labour 
demands. The basic idea has been to open up entry in periods of economic growth and major labour shortages and to close it down again at times of crisis and increased unemployment. While this has been the logic and discourse of immigration policies, the reality has been a relative, continuous open entry. When the Malaysian state closed down or restricted entry, for example during the economic downturns of I997 and 200I, employers' reaction was swift. Even in times of crisis and growing unemployment, the market depended on foreign labour. Thus, the employers argued, if the state wanted to continue promoting economic growth, it would have to open up entry again. Given how dependent the state's legitimacy was on its ability to guarantee this growth, the government complied immediately on each occasion. We can thus conclude that, while on paper (and in the discourse) entry policies were subordinate to the situation of the labour market, in practice they always ended up responding to the employers' demands for foreign labour.

In the case of Spain, the restrictive character of entry policies should also be analysed not only as they appear on paper, but in practice. As in Malaysia, the aim was always to open and close entry in response to demands for labour and protection of the labour market. Nevertheless, in contrast with Malaysia, this policy was manifested in very restrictive practice until 2005. There are several reasons for this. First, for a long period, contracting foreign workers was subject to very stringent evaluation of the national labour market. Second, when prior evaluation of the demands for foreign workers started to be carried out after 2000, the proposed annual quotas tended to be particularly low. This is explained, on the one hand, by the unions' fearful attitude vis-à-vis the entry of new foreign workers and, on the other, by lack of foresight on the part of businesspeople with regard to needs of medium-term contracts, as well as under-representation of small and medium-sized companies (which are the majority after all) in the process of determining quotas. Third and finally, entry policies ended up being more restrictive than initially envisaged due to the complexities of entry procedures and the difficulty of contracting immigrants in their countries of origin.

Indeed, the policy of 'contracting in the country of origin', which requires a job contract prior to arrival, has been one of the great obstacles to legal entry into Spain. In the I990s, the main reason for this was a lack of mediation mechanisms. If the worker did not have some acquaintance in Spain or if the employer had no helpful contacts in the country of origin, it was practically impossible to contract migrant workers. After 2002, when the Spanish government set about trying to manage this mediation with the collaboration of the governments in the countries of origin, there were still several other obstacles. First, not all governments in the countries of origin, which were ultimately responsible for recruitment, were capable of fulfilling this function. Second, even in situations 
where mediation functioned properly, not all employers were willing to approve such contracting of their workers. In sectors such as domestic service, small business and the hotel and catering trade, the significance of the prior working relationship and trust between employer and worker made contracting through governments an especially difficult process. Third, contracting in the country of origin through the different branches of the administration was only feasible where previous bilateral agreement had been reached. This has been yet another element giving rise to tension between state and employers: the state interests that led to the signing of these agreements did not always coincide with those of the employers who had other ideas and preferences about the countries of origin of their workers.

The main effect of these restrictive entry policies has been the creation of a true model of illegal immigration in Spain. In this sense, the market response was very clear: if it was impossible or difficult to contract immigrants legally in their countries of origin, they were found illegally after arriving in the country. In other words, even though legal entry of immigrant workers was restricted, migrants kept coming in anyway to cover the increasing labour demands. Faced with this situation, the Spanish government kept insisting on the need to channel labour immigration legally and thereby to prevent illegal immigration. Nonetheless, it was not until 2005, after numerous and voluminous processes of regularisation, that the government introduced a relatively open entry policy for the first time. This shift seems to suggest that the demands for labour had finally managed to prevail over demands for closure. At the same time, what made this change feasible was the establishment of significant networks between immigrant communities in Spain and prospective immigrants in countries of origin. These social networks came to play the mediating role between labour supply and demand that the state had previously been unable to perform. In other words, thanks to the immigrants' networking, contracting in the countries of origin - the only legal way for an immigrant worker to enter Spain - finally became possible.

While in Spain mediation between labour demand and supply remained in the hands of employers (who ended up turning to the social networks of the immigrants once they had consolidated) or the governments involved, Malaysia's recruitment of labour immigrants has always been run by private agencies. These private agencies, called outsourcing companies since 2006 , have worked as mediators not only between the worker in the country of origin and the employer at destination, but also between employer and state, primarily because they have taken charge of all procedures pertaining to labour immigration - which is to say, contracting the immigrant worker, processing the paperwork for entry and renewal of permit and eventually returning the immigrant to his or her country of origin. Privatisation of the migrant labour system in Malaysia 
has thus ensured, first, that the complexity of procedures associated with contracting immigrant workers has not become, as in Spain, a deterrent factor in the legal contracting of immigrants. Second, the presence of the recruitment agencies has given rise to a system of 'importing' and 'exporting' labour, which the state alone, or the state and businesspeople combined, seemed unable to manage. This explains why the state and the employers have always ended up resorting, however much it goes against the grain, to the intervention of the recruitment agencies.

If privatisation and commercialisation of recruitment eased the functioning of the migrant labour system, it also meant greater costs for the immigrant. Besides paying for a passport, induction courses, medical examinations and levies, the immigrants also had to finance the flourishing business of the recruitment agencies. This led many immigrants to opt for illegal (jalur belakang meaning 'backdoor') or semi-legal (documents that are counterfeited by someone on 'the inside', the so-called aspal documents) entry so as to avoid paying for legal entry's entailed costs. This resort to illegality has occurred in particular with immigrants entering the country in border zones near Malaysia. In these places, illegally crossing the border (which is cheaper, easier and faster) seems to be simply a matter of rational choice: why pay so much and go through so much red tape if Malaysia is right there, just across the sea? In contrast, long-distance immigration (from more-distant Indonesian islands or countries like Bangladesh, Nepal and Pakistan) has mostly taken the legal route, via recruitment agencies. With the distance involved, there seemed to be no other alternative. Finally, as we saw in section 3.4, the presence of these agencies and their irregular practices has tended to place migrants in a vulnerable situation and, directly or indirectly, has led many of them to fall into illegality.

In general terms, we can conclude that Malaysia has presented a relatively open entry policy that is expedited by recruitment agencies. Until 2005, Spain had a relatively closed entry policy, with major deficiencies in mediation between labour demand and supply. After 2005, in order to clamp down on continued illegal immigration, the Spanish government introduced a more open entry policy for the first time. Meanwhile, the consolidation of significant immigrant networks facilitated what had thus far been just an immigration policies myth: employment of immigrant workers in their countries of origin. As for policies regulating residence and hence access to membership, there has been restriction in both cases. While in Malaysia this restriction has been total and indefinite, in Spain it has been partial and temporary - which is to say, it has been applied in specific domains, only during the early years of residence. Nonetheless, it is again important to distinguish between policies on paper and policies in practice because here, too, the markets tended to counteract the conditions that the immigration policies were trying to impose. 
In Malaysia, on the one hand, the immobilisation of immigrant workers, not only within an economic sector, but also in relation to a single employer, has benefited the employers. It has prevented any leaking of foreign workers into other better-paid sectors and, again, the link between residence permit and job contract has truncated the labour rights of foreign workers. On the other hand, related time constraints (a two-year minimum contract and a five-year maximum subject to renewal) have tended to clash with market demands. With regard to the two-year minimum, many employers have deplored the difficulty in contracting foreign workers for temporary projects. This led to sub-contracting workers (since 2006 , via recruitment agencies) and the employment of illegal immigrants. Here, sub-contracting or contracting illegal immigrants, practices frequently related to each another, have been perceived as synonymous with flexibility. As for the five-year maximum, the employers have also complained about the immense turnover entailed. The reason for imposing this time limit has been to prevent 'foreign workers' from becoming 'settled immigrants'. For the labour market, it has meant a constant loss of skills acquired by workers. As such, the resort to illegality has been seen as a way to gain access to immigrant workers whenever needed and for as long as desired.

As for the limits on membership for immigrants in Spain, two major issues should be highlighted. First, the position of the immigrant on the job market is restricted to a particular economic sector and province in the first year. The basic idea is temporary limitation of the immigrant's stay to the kind of work authorised by the entry permit. However, when the year is up, the immigrant can work wherever he or she wants. This means that, unlike Malaysia, the immigrant has unlimited access to the labour market. In fact, this arrangement has not been exempt of tensions. Immigrants' mobility is feared by employers in the lowest-paid sectors, which tend to have high worker turnover rates. It has also been a matter of concern for trade unions and the Spanish government itself, which has sometimes noted with no little dismay how immigrants have moved into economic sectors reserved for national workers so that the worst-paid sectors rely on the entry of new immigrant workers. Second, further limiting the presence of immigrants in Spain has been the factor of time, as fixed in the residence permit. In the first five years, the residence permit is subject to official and effective integration in the labour market. This legality, which is contingent on a formal job in an economy characterised by a high degree of informality, has only led to the legal precariousness of immigrants, who often lapse or relapse into illegality. 


\subsection{Rights' constraints}

The restrictions imposed on access to membership, which are, in practice, restrictions on immigrants' rights, have been incomparably more draconian in Malaysia than Spain. In Malaysia, the presence of migrant workers has been limited in three fundamental ways. First, their work permit is issued for a specific economic sector and tied to a particular employer. As denounced by most Malaysian and international NGOs, this has resulted in a situation of 'sanctioned bondage', as migrants do not have the freedom to move from job to job and their labour rights are actually restricted since their legal presence in the country depends on their employer. Second, the shift whereby the levy changed from being a tax imposed on employers to an income tax on foreign workers has raised the price of being legal and, indirectly, the immigrants' dependence on their employers. Now their bondage is not only defined by conditions of the work permit, but also through the debt that restarts each year when the employer advances the payment of the levy and deducts it monthly from the immigrants' wages. Third, immigrant workers' stay in Malaysia is deterministically temporary due to three stipulations: being 'returned' or 'repatriated' in times of economic downturn, due to illness or pregnancy and/or after five or seven years of working in the country. The final aim of these different time stipulations has thus been to get 'workers' instead of 'migrants'.

In Spain, I985's first LOE only envisaged short-term visas and did not recognise the right to family reunification. Later, though, this started to change. The increasing inflow of immigrants and consequent pressure coming from civil society and opposition parties forced the Spanish government to regulate the right to family reunification (I994 and I996), to extend the duration of permits and to introduce the permanent residence permit for the first time (I996). The new Ley de Extranjería of 2000 introduced the right to family reunification in terms that were coherent with laws of the European Court of Human Rights and that tended towards equality of rights between legal residents and citizens (freedom of circulation, assembly, association, etc.). However, as already shown, two basic constraints remained: the restriction of work permit to a certain sector and province during the first year and dependence on a formally recognised job for legal residence during the first five years. Despite these limitations, the rights of immigrants in Spain are much more robust than those in Malaysia. Besides recognition of their social rights (for example, the right to unemployment or to family reunification), the former have been able to settle in the country and obtain not only permanent residence, but also citizenship.

To sum up, immigrants' rights are very limited in Malaysia and they can be limited with ease. In Spain, immigrants' rights were relatively limited, but expanded as the burgeoning presence of immigrants in the 
country made it necessary to make their rights equal to those of Spanish nationals. Civil society and the opposition parties have played a highly significant role in the legal inclusion of immigrants. Their demands for equality could not be opposed by the government before the law, for otherwise its own democratic credentials would be jeopardised. As the Catalan government argued when an employers' association proposed contractually binding newly arrived immigrants to their employers, such discrimination is illegal and anti-constitutional. This explains why Spain did not opt, as Malaysia did, for a policy that drastically restricted access to membership. As a liberal democracy, it simply could not do so. This raises further questions. What actually did transpire? To what extent has Malaysia, as its policies suggest, been able to convert immigrants into mere temporary workers or, in other words, labour that can be imported or exported at will? And to what extent has Spain really been inclusive of its immigrants?

In Malaysia, the restrictions imposed on migrants' stay have tended to make legality a disadvantage so that, in many cases, resorting to illegality or remaining illegal has been advantageous. First, unlike legal immigrants, the illegal are not bound to an employer. Not having a signed contract means that immigrants tend to be freer to change jobs when they want and hence have more opportunities for negotiating pay and working conditions. Second, being illegal can be cheaper. It circumvents all costs associated with legal entry and, once in the country, there is no levy to pay. Third, illegality tends to make the stay in Malaysia rather less temporary. Unlike legal immigrants, illegal immigrants are not automatically repatriated in instances of economic crisis, illness or pregnancy, or after five years of working in the country. In short, the resort to illegality both for migrants who enter the country illegally and those who become illegal after 'running away' from their employers has made the immigrant worker situation in Malaysia less manageable than the country's immigration policies would suggest. On paper, the policies do indeed trim down the rights of immigrants. In practice - and this is quite curious when considered from a Western standpoint - the limiting of rights has encouraged illegality as the better alternative.

If in Malaysia illegality has been one way of getting around the restrictions imposed on the presence and rights of immigrants, in Spain illegal immigration has brought about a rather different situation: having immigrants but without recognising their rights - or at least trying not to. Unlike legal immigrants, the illegal only have limited social rights. They do not have the right to unemployment benefits or to family reunification and they actually lack labour rights. These rights may be formally recognised, but illegality often means they cannot be exercised. Finally, their position on the labour market is mainly confined to the informal economy or to those sectors most marked by a high degree of labour precariousness. 
If we bear in mind that a major proportion of labour immigration in Spain has been illegal at some point, we might wonder to what extent illegal immigration has not been a de facto way of obtaining immigrant workers without rights, or with only minimal rights.

This seems, in fact, to be the case. Illegal immigration has effectively constituted a way of covering the demand for cheap foreign labour without needing to open up the borders to entry and membership. In this regard, we might conclude that, in the Spanish case, illegal immigration seems to have enabled reconciliation between demands for foreign labour and demands for closure. Nonetheless - and here rights constraints enter the picture again - illegal immigrants could not be completely excluded. If the first LOE hardly recognised any rights of illegal immigrants, different legal rulings and multiple modifications to immigration law have changed this situation. Legal rulings have constituted progressive recognition of their basic rights. The new immigration law of 2000 made access to health services and education contingent on registration in el Padrón, not legal residence. This means that illegal immigrants obtained access to minimal social services. Due to the rule of law and the political process, illegal migrants thus could not be totally excluded. Nevertheless, while they were gradually included in some aspects of the social sphere, in work terms they continued to represent a legally non-existent and hence rightless labour force.

\subsection{Regaining control}

As we have seen, demands for closure were met differently in Spain and Malaysia. Despite the differences, the measures introduced to restrict entry and/or membership tended in both cases to produce illegality. In Malaysia, the costs associated with legal entry and the commercialisation of recruitment made illegal entry a faster, cheaper option. Obstacles to membership also tended to make illegality an advantage. In Spain, the difficulty of contracting workers in their countries of origin meant that illegal contracting on arrival was to become the norm. Factors leading to many immigrants losing their legal status were the fact that legality is contingent on having a formally recognised job in the first five years of residence and the snail's pace of permit renewal paperwork. In both countries, while the main aim of immigration policies was to regulate and control immigration, one of its consequences has been illegal immigration - characterised precisely by lack of regulation and control.

Malaysia and Spain responded to the situation with different kinds of regularisation programmes. Both attempted to regulate and control those immigrants who had escaped from regulation and control. More than being a form of inclusion, these regularisation campaigns should be un- 
derstood as a means of regaining control. Since the meanings and forms of this control were different in each country, the motives and mechanisms of regularisation also present significant differences. Malaysia's basic goal was, as one national official declared, 'to keep track of their number, location and origin' (Business Times 25 July I996). In other words, an attempt to reintroduce illegal immigrants into the labour system was made by determining their number and origins, guaranteeing their immobilisation within the labour market, making their residence temporary and tied to a single employer and obliging them to pay taxes. Inasmuch as immigrants were exclusively perceived as workers, it is not surprising that the regularisation only applied to workers with a job. In fact, on each occasion, it was the employers that regularised their workers. While the employers' associations tended to welcome these processes, the trade unions and the opposition parties systematically opposed such measures, viewing them as yet another episode of backing down by a government that was yielding to employers' insatiable demands for more and more foreign workers.

Up until 200I, Spain's regularisation procedures functioned-and were so presented on each occasion - as corrective measures a posteriori to immigration policies that had failed in their most basic aim: regulation of immigration. Whether it was because legal entry was so difficult or because the few immigrants who entered legally (or were subsequently regularised) lost their legal status with the years, or because many illegal immigrants were excluded from the regularisation processes, the government was obliged to introduce frequent regularisation programmes (in I985-I986, I99I, I996, 2000 and 200I). Each was an attempt to achieve what immigration policies were hitherto unable to do, and also to bring the numbers of illegal immigrants down to zero before introducing new immigration policies or laws. In these processes, duration of residence, rather than having a job, was the main requisite for regularisation. Those unable to produce proof of their registry in the municipality tried to produce as many bits of paper as evidence of the length of their stay. In many situations, then, regularisation depended on amassing back-up documents and the willingness of provincial administrations to recognise them as valid.

The regularisation process of 2005 was different. After five years of a particularly restrictive entry policy (which coincided with the PP's second mandate), this time the aim was to regularise those workers (and employers) for whom immigration policies had left no alternative other than illegality. Unlike previous attempts, the aim of the exercise this time was clearly to regularise those workers with a job and even, it might be said, their employers. Moreover, it was the result of a clear agreement between the government, employers and the trade unions. With this regularisation, the government sought to gain greater capacity for control - at a time when over a million illegal immigrants were calculated - and to ensure that more people would be making social security contributions. The employers saw 
in this regularisation a recognition of their demands for foreign workers, as a way of having foreign workers within the law and therefore on more stable terms. Trade unions pushed for this regularisation process with the aim of stamping down on the informal economy and thereby imposing minimal wage and working conditions.

A perusal of the results of the regularisation processes in Spain and Malaysia reveals one significant difference. While in Malaysia the results were always numerically limited, in Spain the numbers of people involved kept rising. Explaining why the regularisation processes had limited results in Malaysia, employers have always referred to the long, complex and costly procedures of regularisation both in the countries of origin (normally Indonesia) and in Malaysia. This would explain why in 1992 and I996 most of the immigrants who were initially registered never came to be regularised or, in other words, were lost somewhere along the way. Another explanation for the limited results of regularisation processes in Malaysia is that one might suppose that not all the employers were keen to regularise their workers. As noted above, illegality was also a means of increasing the flexibility and length of stay of foreign labour. Just as not all employers were interested in regularising their workers, many workers might not have been willing to be regularised either. If illegality was a way of getting around the limitations imposed on legal immigrants, the regularisation processes would seemingly have little to offer those immigrants who had opted to become or remain illegal.

Meanwhile, three factors may explain the success of the regularisation processes in Spain. First, many employers did opt to regularise their workers. This was especially clear with the regularisation of 2005 , which suggests that in many cases (and particularly in the early 2000 s) employment of illegal migrants was more the result of entry policies' restrictiveness than a way for employers to access a cheap, malleable labour force. Second, in all the regularisation processes, the state was the most interested party in the drive to regularise illegal immigrants. If the state did not reduce the already existing numbers of illegal immigrants, it would be difficult to introduce policies and laws that would finally lead to regulation and control of immigration. This would explain why, for example, the state decided in $200 \mathrm{I}$ to revise applications that had been denied in the regularisation of 2000 . Third, analysis of the implementation of Spain's regularisation processes highlights the key role of social organisations, immigrants' associations and trade unions. From the early i99os, these organisations, which saw in regularisation a form of recognition and extension of immigrants' rights, were crucial for publicising and conveying information and in the selection and processing procedures prior to the applications being filed.

At a more general level, this difference in the results of the regularisation drives in Malaysia and Spain should be understood in relation to the 
meaning of illegality itself. In Malaysia, illegality came in tandem with legality. In 2006 , there were almost two million legal immigrants and an estimated one million illegal immigrants. The latter either came from zones close to Malaysia or had become illegal upon escaping from their employers. In contrast, thanks to a tremendously restrictive entry policy, illegality in Spain was, until 2005, the only way of entering the country. If one wished to work in Spain, the only alternative was essentially to come into the country (usually as a tourist), stay on, work illegally and eventually apply for regularisation. Unlike Malaysia, regularisation processes have long worked as the entry policy. Joint analyses of entry policies and regularisation processes would lead one to a very different conclusion concerning how the dilemma of markets and citizenship was resolved in Spain. As noted above, it is not that until 2005 the state gave priority to demands for closure over demands for labour. While the entry policies apparently responded to the demands for closure, the regularisation processes effectively made it legally possible to cover the demands for labour.

However, this use of regularisation processes as entry policy has two significant implications. First, it makes illegality a requisite for legality. Thus, in order to live and work legally in Spain, one had to live and work illegally beforehand. This means fewer social rights and few (or very few) labour rights. Semi-recognition in the social sphere and non-recognition in the labour domain became an antechamber to what was eventually 'earned' social and labour recognition. Second, using regularisation processes as the main form of entry, while residence (in the first five years) was contingent on formal integration in the labour market, has only produced more illegality. This is basically because, until 200I, while period of residence rather than holding a job was the chief requisite for regularisation (with the first renewal after one year), work and not residence became the sine qua non for staying legal (see section 4.6). This means that even if the immigrant might have managed to become regularised, this would be of no help at all if, after the one-year period had expired, he or she were unable to demonstrate effective, formal integration into the labour market. As such, many regularised immigrants became illegal yet again.

\subsection{Final exclusion}

If regularisation is an instrument for regaining control, deportation policies have been presented in both Spain and Malaysia as the way of reducing illegal immigration by, namely, resorting to the physical expulsion of illegal immigrants. Expulsion of individuals without residence permits has been justified in both countries under the pretext of national 
sovereignty, alluding to the idea that the state not only has the right - but also legitimate authority - to control any activity in national territory, and thus to determine who can and cannot enter the territory and come to live there. National sovereignty has functioned not only as a way of justifying these policies, but also as an end in itself. The policies have aimed to demonstrate and stage state control over national territory, something normally conducted with much media fanfare and political acclaim. Moreover, in Malaysia and Spain, discourse on deportation has sought the penalisation of the immigrants' illegal status. In both cases, the logic has been punishing by deportation those individuals who dared to enter the country and remain without permission. Frequently presented in terms of 'just deserts', the punishment has taken the form of removing the illegal immigrants as fast and as far as possible from national territory.

While the discourse on the deportation of illegal immigrants has been notable in both countries for its emphatic bluntness, its policy implementation has been somewhat limited. First of all, the shortfall is explained by the high costs associated with deporting illegal immigrants. These arise from monitoring and detention campaigns, the expenses incurred in maintaining illegal immigrants in detention camps and, finally, deportation itself. Second, deportation policies have also been constrained by legal considerations. In both Malaysia and Spain, the state has always wanted more control, or more capacity thereof, than it actually had. This has led both states to extend its control by increasingly swifter and more expeditious measures, essentially by reducing judicial control. In Malaysia, this has taken the form of the privatisation of detention processes, which have been handed over to the paramilitary civil volunteer corps RELA. Spain has acted by prohibiting judicial suspension of expulsion orders. Moreover, lacking the power to extend its capacities without restraint, the state has tended in both cases to infringe on legally imposed limits. Defined by Malaysian immigration officers as 'extra-official practices' or 'backdoor policies', this has implied deportation practices (with orders of collective expulsion, expulsions at the border or deportation to third-party countries) that can be labelled as 'illegal'.

One of the major differences between Malaysia and Spain emerges in terms of the state's possibilities to control and deport immigrants. In Malaysia, it has been possible to whittle away the rights and legal protection of illegal immigrants in favour of greater and allegedly more effective state control. In political terms, the Malaysian state has been able to practise its so-called backdoor policies relatively openly, without having to retract or justify them. In contrast, the Spanish state has been doubly constrained. On the legal plane, for example, when the first immigration law of I985 aimed to 'equip the executive with the legal means to defend Spanish society more effectively against gangsters and delinquents' (Spanish Parliament, ig February I985), a number of constitutional and legal rul- 
ings almost simultaneously limited the possibilities of detention and deportation, creating a body of laws that were critical of administrative excess. On a more political level, and also by way of example, when the PP government collectively deported a hundred African immigrants without legal guarantees, immediate outcries came from the ombudsman, trade unions, NGOs and opposition parties denouncing this action. As a result, the Ministry of Interior had to offer an explanation before the Parliamentary Commission for Justice and the Internal Affairs.

In this regard, we may conclude that, in Spain, it is not so much the case that the state has not attempted to restrict the rights of illegal immigrants as a means of increasing its control, but rather that, in both legal and political realms, it has been kept in check by judiciary power, civil society and opposition parties. If one bears these constraints in mind, it is not so surprising that the space from which the greatest deportations have occurred has shifted from the heartland of national territory to the border and 'beyond'. Along the fringes, the Spanish state has deported would-be immigrants without having to open up administrative procedures, to know the origins of the immigrants or to count on governments of countries of origin agreeing to repatriation. Similarly, beyond the border, in so-called transit countries, it has been possible to detain immigrants, including prospective ones, and deport them without major accountability. Perfect examples of this are the detention camps in countries like Morocco and Mauritania (frequently financed, if not directly constructed, by the Spanish state) and the way immigrants rejected at the Spanish border are dealt with: deported and subsequently dumped in the desert.

This outwards displacement of migratory control clearly contrasts with the Malaysian model. In the post-colonial state of Malaysia, the outer frontiers have mostly been of only peripheral interest to the national elites located in the centre. While these 'remote places' have tended to remain at the margins of the border logic, migratory control has tended to be carried out well within the national territory. It is Kuala Lumpur, in particular, where the detention campaigns have taken place. It is there that the migratory control has been staged and, as a result, there, above all, where illegality has become synonymous with deportability. This has a particularly significant implication with regard to deported illegal immigrants: while in Spain deportability looms over those immigrants who are trying to enter the country, in Malaysia it affects those who are already in the country and, in most cases, working. Here, deportation of illegal immigrants has another meaning. If one bears in mind that, in Malaysia, deportation campaigns tend to coincide with periods of economic crisis, it might be said that deportation is not only a form of control over the territory, but also a way of imposing temporality on the work of illegal immigrants. Although illegal immigrants tend to escape state control and its temporalities, deportation campaigns also seek to turn illegal immi- 
grants into a flexible labour force that is 'importable' and 'exportable' at will.

Finally, it would be too simplistic to conclude that Malaysia's deportation policies unfold within national territory while Spain's are carried out on the borders and beyond. What has happened in Spain is rather more complex. While the state keeps asserting its authority in deciding who can and cannot stay, legal and political restraints thwart its chances of deporting illegal immigrants once they have entered national territory. It is not that there is no control, but often this control cannot be translated into deportation. Unlike Malaysia, where the majority of detained illegal immigrants is deported, in Spain only one in every five is. The rest, after 40 days of detention, are freed pending an expulsion order. This implies that the risk for illegal immigrants once in Spain is not so much deportation, but rather being legally expelled despite actually being non-expellable (see section 4.7). Until 2008, having a non-executed expulsion order meant not being able to opt for regularisation, which meant being non-expellable but unregularisable. Legal limbo - resulting from the internal contradictions of a system that aims to expel the immigrants but is unable to see the project through - is precisely what characterises the Spanish model. Once inside the country, an illegal immigrant runs fewer risks of being physically 'outside', yet this does not mean that he or she is legally 'inside'. 



\section{Conclusions}

\subsection{State response to labour demands}

After the guestworker experiences in Europe and the US during the I950s and ig6os, there was general consensus that guestworker programmes had failed wherever and whenever they had been tried (Castles I986; Martin 2000; Martin \& Teitelbaum 200I). In particular, the conclusion was that they were inherently flawed because, as the saying goes, there is nothing more permanent than temporary foreign workers. Prominent among the reasons given in the academic literature to explain temporary workers' propensity to settle was the argument that foreigners in liberal democracies are entitled to rights under the aegis of liberal constitutions (Hollifield I992). In a similar vein, Freeman (I995) concluded that immigration politics in liberal democracies are 'expansionist and inclusive' because the benefits related with immigration are concentrated whereas the costs tend to be diffuse. More recently, along similar lines, Martin and Ruhs (2006) have argued that there is a trade-off - which is to say, an inverse relationship - between the number of migrants employed in lowskilled jobs and the rights accorded them: the more immigrants, the fewer rights. A similar argument leads Arango (2003: 3) to conclude that while democratic countries tend to restrict numbers, non-democratic or autocratic societies tend to restrict rights (see section I.4).

The comparison between Spain and Malaysia seeks, in the first place, to test this argument. By first considering how the Spanish and the Malaysian states have responded to the demand for foreign labour, this book aimed to analyse to what extent we are looking at such distinct models. To be more specific, the question might be worded as follows: to what point has Spain had a policy of low numbers and high rights and Malaysia one of high numbers and low rights? At first sight, a review of entry policies over the past twenty years leads one to the conclusion that, in effect, the state of Malaysia has opted for a policy of high numbers and low rights. The state has not restricted the entry of migrant workers, though has placed limits on time of residence, position in the labour market and social and labour rights. In Malaysia as many foreign workers as demanded for by employers have entered the country. Restrictions do not appear at the point of entry, but are enforced once the immigrants are 
in the country by limiting their access to membership. In contrast, the Spanish state opted for a particularly restrictive entry policy until 2005. While demands for labour kept growing throughout the I990s, with particularly acute needs from 2000 to 2007 , the government did not respond accordingly by adjusting its immigration policy to let in greater numbers of workers. In this regard, unlike Malaysia and post-war Western European countries, Spain exhibited a clear contrast between the economics and politics of immigration. Not seemingly applicable to the Spanish case are the well-known words of Berger (Berger \& Mohr 1975: 87): 'To those who have machines, men are given.'

In order to explain the high-numbers policy in Malaysia one needs to refer not only to the role of employers in immigration policymaking, but also to the development-oriented project of the state. As noted in section 3.2.3, the New Economic Policy (I97I-I990) and its derivations sought to restructure the legacy of colonial society by means of promoting economic growth. While social programmes aimed at situating the Malay in a better position on the labour market, economic growth continued to depend on cheap labour. In this context, there was (and still is) general consensus that employment of migrant workers was necessary for both social stability and economic growth. In Spain, by contrast, the nature of immigration policies arose from very different priorities. First, the demand for closure was determined by EU requirements. Second, given that unemployment figures had risen to over 20 per cent by the mid-I990s, immigration policies and their implementation tended more to guarantee protection for national workers than to heed the employers' demands (see section 4.4.I). Finally, some restrictive aspects of Spanish immigration policy should be understood vis-à-vis policies not working well and, more specifically, the slowness of procedures and the politically much-vaunted myth of recruitment in countries of origin.

However, to conclude that Malaysia is characterised by an open entry policy and Spain by a restrictive one would be to remain on the surface of things, or to settle for an analysis of written policy and its implementation without inquiring into its effects. This distinction between policy on paper and in practice is especially significant for Spain. In Malaysia, immigration policies produced what they claimed: many immigrants with very few rights. What happened in Spain was very different. Despite the restrictiveness of its policies, immigrants kept coming in all the same. As many scholars and the stakeholders themselves (starting from the leading political parties) have noted, the mismatch between significant demands for foreign labour and highly restrictive entry policies led to an out-and-out model of illegal immigration. In this regard, if one focuses on how the labour demands were actually covered, one would conclude that, in Spain, too, the demand for labour led to a situation of high numbers and low rights: high numbers in the sense - to go back to Berger's formulation - 
that people with machines obtained men to work them; low rights in the sense that, in their capacity as 'illegal', immigrant workers entered the country and worked without having a legal existence. They were bereft of minimal social and labour rights, and their presence did not afford access to permanent residence or citizenship. Like workers in Malaysia, migrant workers in Spain also 'entered' though, once 'inside', they were still 'outside' in any social, labour-related and symbolic sense.

Joint analysis of entry policies and regularisation programmes leads one to a similar conclusion, although there is further nuance. As observed throughout this study, the Spanish regularisation programmes operated for a long time as the real entry policy (see in particular section 4.6). Until 2005, legal entry as an immigrant worker was so difficult that people usually entered the country, stayed on and worked illegally until eventually becoming regularised. In this regard, while entry policies were particularly restrictive, the mechanisms of regularisation ended up making entry relatively open. However, entry via regularisation has always meant deferment since an immigrant could only opt for regularisation if he or she had been in the country illegally for some time. Making illegality a requisite for legality meant that those who entered the country had to come in with very few rights. This was undeniably a policy of high numbers and low rights, though the big difference here is that once they were regularised and after some years of conditional residence (see section 4.5.3), most of the immigrants ended up obtaining a permanent residence permit or even Spanish citizenship. In the long term, the regularisation policy thus eventually led to a situation of high numbers and high rights.

Finally, to conclude this account of the Spanish model, 2005 represented a major change in policy. Along with a final regularisation process that involved almost 700,000 applications, the government finally switched to a relatively open entry policy. The main reason for this, as repeatedly proclaimed in recent years by the government (regardless of different parties and political hues), was to channel immigration legally, thus cutting down the numbers of illegal immigrants. No doubt, illegal immigration combined with periodical regularisation processes could not continue ad infinitum without undermining the legitimacy of the state, for it had to be seen fulfilling its role of controlling immigration flows. Accordingly, to extricate itself from the unmanageable situation of continuous correction of a non-functioning migratory system, the government finally opted for an entry policy that was more visibly in keeping with demands for foreign workers. The result was a policy of high numbers and conditioned rights, which eventually led to a situation characterised by high numbers and high rights. 


\subsection{Markets, citizenship and rights}

This research started out from the assumption that the state is required to respond simultaneously to contradictory demands in the field of migration control. In chapter I, these contradictory demands were identified as a double dilemma. First, while markets require a policy of open borders to provide as many foreign workers as demanded for by employers, citizenship seems to require some degree of closure to the outside. Second, while the exclusive character of citizenship demands closed membership, civil and human rights seem to undermine the state capacity to exclude foreigners once in the country. This double dilemma or trilemma between markets, citizenship and rights leads one to the question of how states manage to reconcile such conflicting demands. In the context of this research, the key question to consider is how the states of Malaysia and Spain attempted to solve this trilemma. As the countries seem similar in terms of markets and different in terms of citizenship and rights (see chapter 2), this question implicitly entails two other questions: first, whether different features in terms of citizenship and rights lead to different arrangements, compromises or choices in terms of migration control; and second, given these differences, what Malaysia and Spain tell us about the relationship between markets, citizenship and rights.

It should first be recalled that, as we have just seen in the previous section, both cases present a policy (either on paper or in practice) of high numbers. Hence, in each of the two countries the market has ruled. In both Malaysia and Spain - to return yet again to Berger's formulation those who have machines always obtained men. This conclusion coincides with that reached by other scholars vis-à-vis countries 'without immigration', or better said although it is not the same thing, 'with zero-immigration policies' (Groenendijk \& Hampsink I994; De Lange 2007). In all these scenarios, employers always found a way (direct or indirect, explicit or implicit) to obtain migrant workers. In Malaysia, entry policies have been notable for their sustained openness. When faced with economic crisis or increased unemployment, the state of Malaysia closed or restricted entry, employers reacted by protesting at serious labour shortages and the state always responded by immediately reopening the border. Although Malaysian scholars have interpreted these swings in immigration policy as a demonstration of its ad hoc nature and lack of coherence, they were really part of a continuum. The present study reveals how the entry of migrant workers was in fact never a matter for negotiation: entry policies simply responded to the market demand.

In Spain, the response to markets was for a long time more a question of policy outcomes than policy objectives and implementation. As we have seen throughout chapter 4, immigration policy in Spain gave priority to demands for closure until 2005. In this regard, if we analysed entry 
policies alone, we would agree with Joppke (I998a: I9-20) who states that Western European immigration policies have tended to be guided by restrictionist national interest. Nevertheless, as we have seen, the clash between the politics and economics of immigration ended up giving rise to an outright model of illegal immigration. This has had two significant implications. First, it means that immigrants kept coming in and that labour demands could be covered despite the restrictive immigration policies. Second, if the desire was to re-establish state control over migratory flows, the presence of these immigrants had to be recognised (by means of regularisation drives), while the further entry of immigrants had to be legally channelled by means of more open entry policies. This suggests that, in the long term, the factor of markets ended up determining not only migration flows, but also migration policies.

Given the predominance of markets in both cases, I have explored how the fact that 'markets ruled' affected, transformed or adapted to the demands for closure and the extent to which rights posed constraints on the state capacity to control migration. If we take the existing literature into account, Malaysia would seem to have fewer demands for closure and fewer rights constraints than Spain (see section 2.2). The former assumption in the literature of few demands for closure has been argued on the basis of Sadiq's (2005) study, which shows that the distinction between citizens and non-citizens is largely meaningless in Malaysia, resulting in what he defines as weakly institutionalised citizenship. The latter argument of low rights constraints is generally inferred from Malaysia's being a less liberal or even authoritarian state. However, detailed analysis of the formulation, implementation and outcomes of migration policies in Malaysia and Spain leads one to slightly different conclusions. First, this study makes clear that both countries had significant demands for closure. The main difference is how these demands were met. Second, although rights constraints are indeed characteristic of Spain as a liberal state, this does not mean that Malaysia could completely restrict migrants' presence in the country or that Spain was constrained by rights at all times or in all domains and geographies of migration control.

As we saw throughout chapter 3, Malaysia's demands for closure certainly played an important role. They took on significant dimensions when Indonesian migrants started to move into urban areas, namely in economic sectors reserved for local workers. My main argument is that the frontiers tended to close to the extent that immigration was perceived as a threat to social restructuring programmes and, particularly, to the socioeconomic promotion of Malays. In fact, only by referring to this gradual closure of borders in combination with recognised weighty demands for labour can we explain the establishment of a guestworker programme in the early I990s. Like any guestworker programme (see Garcés-Mascareñas 2004), this policy responded to the demands for foreign workers 
by opening up entry and to the demands for closure by restricting access to membership. In other words, by letting people in as workers, but keeping them out as immigrants, the state of Malaysia attempted to cope with the dilemma between markets and citizenship. However, it is important to note that this situation applies exclusively to Peninsular Malaysia because, as noted earlier, Eastern Malaysia is another story. Given the fact that Sadiq's (2005) observations on Malaysia are based on research done in Eastern Malaysia, it is hardly a coincidence that he comes to such dissimilar conclusions.

Diversity of worlds within the same national territory should not be overlooked. Although the issue lies beyond the scope of this research, it is important to note that such variation may have something to do with the nature or the 'genealogy' of the state of Malaysia. As observed by Wong (2006: 9I), in post-colonial states, border regions tend to remain, to a large extent, rather peripheral to the interests of the national elites installed in the centre. State indifference towards border regions - this perceived and ideologically constructed 'beyond' within the national territory - would explain the existence of this dual logic. On the one hand, in border regions like Eastern Malaysia, ethnicity rather than citizenship would continue to play a crucial role in drawing the boundary between insiders and outsiders. Therefore, as observed by Sadiq (2005), the distinction between citizens and non-citizens would be largely meaningless there. On the other hand, in the administrative centre of Peninsular Malaysia, the borders and boundaries of the new Malaysian nation-state would finally be imposed. So, too, would there be demand to distinguish between nationals and foreigners. In this regard, we could conclude that, when focusing on the hearth of the nation-state rather than on its periphery, Malaysia does not differ significantly from Spain in terms of claims to sovereignty and forms of citizenship.

Spain's concrete reasons for closure were multiple. As shown throughout chapter 4 and again in section 5.I, closure was determined by pressure from the EU and a demand to protect the national labour market. These demands for closure turned into severe restrictions on entry and partial restrictions on migrants' access to membership. While restrictions on entry were thwarted by the market factor, restrictions to membership were challenged by the rights factor. The latter circumstances may be explained by, as Hollifield, Joppke and Guiraudon have all pointed out regarding Western Europe, the presence of a strong, independent judiciary and its power to curtail the state's capacity to restrict immigration. However, in contrast with what Guiraudon (I998, 2000) concludes, most social rights were not achieved behind the closed doors of the bureaucracy and the courtroom. The political process, as Freeman (I995) notes referring to the US, played a major role. In Spain, some of the rights obtained by immigrants came by way of new immigration policies and laws with 
origins not only in Parliament, but notably in a political debate that began outside it, with the ombudsman, opposition parties, immigrants' and social organisations and trade unions. Yet it would be erroneous to suppose, as Freeman does, that the state's position has been neutral or merely reactive to the different interest groups. The very legitimacy of the state depends on its ability to guarantee these rights. When mainly civil society, but also opposition parties, started demanding more rights for foreign residents or greater equality between them and citizens, the state thus had no alternative but to acquiesce.

However, it would be a mistake to conclude that in Malaysia immigrants can be or are objects of exclusion, while in Spain the situation is notable for legal inclusion. Both cases have significant if subtle distinctions. It is precisely such nuances that signal this study's distance from a line of academic literature (mainly represented by Hollifield, Joppke and Guiraudon) emphasising the role of rights in liberal democracies. Many of these authors tend to assume that the governments of non-liberal democracies get around rights-based impediments 'because there are fewer legal or institutional constraints on the behaviour of states vis-à-vis foreign nationals' (Hollifield 2004: II). A quick overview would seem to uphold this conclusion: unlike Spain, immigration policies in Malaysia can immobilise immigrant workers, make them dependent on their employers and ensure that their stay be purely temporary. Nevertheless, by attending to how these policies actually worked, this study makes it clear that restrictions on migrants' rights have also had their limits in Malaysia. They were not imposed by legal or political means, but rather by the immigrants themselves directly challenging the legal and political system in escaping from state control by means of resorting to illegality.

In Spain, one should not forget that the policy of high rights was the outcome only in the last instance. First, given the mismatch between the politics and economics of migration, most immigrants in Spain were there illegally. Hence, we speak here of low rights in the sense that illegal immigrants were only partially recognised in the social domain and not recognised in the labour domain, while their presence in the country did not pave the way for their remaining in the country as permanent residents or citizens. Although a number of court cases and a series of modifications to the immigration laws extended the rights of illegal immigrants (see section 4.3.3), in general terms their situation has been one of vulnerability in the legal, social and labour spheres. Second, in the early years of residence, immigrants acquired only conditioned rights. As I have noted repeatedly, legal residence has depended on the first five years of formal, effective integration into the labour market. While the rights of legal immigrants were being extended throughout the I990s, this dependence ensured that legality (and its associated rights) was nothing more than a status contingent to having a formally recognised job. As a result, given 
the significant immigrant presence in the informal sector of the Spanish economy, this status was in reality changeable and precarious.

To conclude, in both Malaysia and Spain, entry has been determined by markets. Basically, in each case, as many immigrants as have been required by employers have entered the country. Characterised - explicitly or implicitly, directly or indirectly - by what might be described as 'open borders to foreign labour', in this situation both states have attempted to block access to membership. The main difference lies in the factor of time. While in Malaysia the aim has been to make exclusion total and indefinite, in Spain it has only been feasible in a partial, temporary form. In both cases, then, the functioning of citizenship's external exclusive dimension has led to inflicting forms of exclusion from within. However, in Spain, the possibility of indefinite exclusion, with regard to both legal and illegal immigrants, has been foiled by rights constraints. In Malaysia, neither legal nor political processes have been able to restrain the state's power to control or limit the presence of immigrants in the country. In this sense, Hollifield would be correct in stating that the non-democratic states are less encumbered. Nonetheless, to think that in the absence of legal or political limits there are no limits at all, is to think exclusively within the parameters of la pensée d'état. In Malaysia, too, the words of Max Frisch apply: the state 'asked for workers, but human beings came'. Here, as we will see in section 6.4, the humanity of migrant workers has not been upheld by the courts or by social and political actors, but rather by the immigrants themselves through opting for illegality.

\subsection{The illusion of migration 'management'}

By the I970s and I980s, as noted, there was general consensus that guestworker programmes had failed as instruments for managing temporary labour migration. Ever since, most studies in Western Europe have focused on family immigration, refugees or the processes of integration. As different scholars have discussed labour immigration, they have tended to confine their focus to analysing entry policies, while overlooking the effects of these policies on migratory flows and how they have combined with other measures such as regularisation programmes. If we take the whole - which is to say, entry policies plus their effects and in combination with other migration policies - the scenario appears very different from the one 'imagined' from the state perspective and, frequently, from the standpoints of social and political sciences. For instance, if we think that Spain's situation can be defined in terms of open borders to foreign labour and partial exclusion of migrant workers in the first years of residence, the result is actually not so different from that of the notorious (more than once 'dead' pronounced) guestworker programmes. 
One major difference in Europe is that, in the past, the partial and temporary exclusion of migrant workers was part of an explicit policy. In recent decades, it has to some extent come about as a result of policy effects or, put plainly, what was not committed to writing. This brings us to another important difference. As I have prior remarked regarding that which is inexplicit and unwritten, unspoken policy has run the risk of undermining the state's legitimacy vis-à-vis its function of controlling migration flows. In contrast with the past, this has not always been policy agreed on by three parties (state, employers and trade unions), or one with broadbased social and political support. It has been more a case of the effects of a 'want-to-but-can't' policy, which has therefore needed constant revision by means of periodical regularisation drives. On the one hand, migrants were demanded for by employers. On the other hand, they were not wanted in the newly risen contexts of the EU and high levels of unemployment in Spain. This 'want-to-but-can't' policy was resolved in practice by policy outcomes (illegal migration) and the combination of different migration policy measures (entry policy plus regularisations). At the same time, in being inexplicit and unwritten, this policy runs the risk of being experienced - and labelled - as 'failed policy'. This explains why the Spanish government decided in 2005 to opt for a more open entry policy that would ultimately demonstrate a certain degree of state regulation and control over migratory flows.

Despite these differences, the great similarity between past and present in Europe is to be found in the tension between demands for foreign labour and those for closure or, more specifically, between wanted foreign workers and unwanted migrants. There are also some common points in the outcome of this dilemma. In the cases both of post-war guestworker programmes and Spain's situation in recent decades - with a model that has combined illegality with regularisation programmes and, subsequently, legal entry with conditional membership - we have a policy essentially marked by: I) high numbers, low or conditioned rights in the first years and 2) high rights in the long term. The first part of the equation is the result of immigrants being purely taken as 'temporary workers'. In this sense, the resemblance with the Malaysian case is clear. In post-war guestworker programmes, in Spain and in Malaysia, migrants found themselves in similar circumstances: authorised by governments to cross their borders to look for wages on a temporary basis; being guests and aliens in states that have defined them essentially as workers; and, finally, expected to leave the country upon expiry of their contracts or conclusion of the period of economic growth that brought them there. To sum up, both in the past and in more recent decades in Spain and Malaysia, states have operated under the illusion that immigration is an 'economic matter' and that migrants are thus commodities that can be imported and exported at will. 
The second part of the equation is the result, as we have seen, of constraints imposed by the legal and political systems. A conclusion to be drawn is as follows: it is not that immigrants could not be excluded in liberal democracies, but rather that they have only been excluded in a partial, temporary way. This is the big difference with Malaysia, where it has been possible to exclude migrants totally and indefinitely. Yet, the attempt to turn foreign workers into mere merchandise for import and export as and when demanded has not been completely successful either. Here, too, the deluded notion that immigration is a purely economic matter to be managed by the state has been challenged by the fact that 'human beings came'. While in Europe, via the guestworker programmes and Spain's situation in recent decades, the humanity of migrant workers has translated both in the medium and long term into permanent residence, in Malaysia it has been translated into illegality. One might well ask to what point these two outcomes can be explained by the political context and the role of rights. To be more precise, to what point has the illusion of migration 'management' as an economic matter been translated over time into permanent migration in liberal democracies and illegal migration in non-liberal democracies?

Europe, past and present, would constitute the perfect example of the former. The Gulf States and other Asian countries would exemplify the latter. Several studies have revealed how, as with Malaysia, in other countries illegality has been a way of escaping state control (see e.g. Moors \& De Regt 2008: 163). While these examples would seem to confirm the relationship between rights and policy outcomes, this observation should also be fine-tuned. First, as in the Spanish case, a very restrictive policy vis-à-vis low-skilled immigrants, despite huge labour demands, does not in the short run produce permanent residence, but rather illegal migration. In the case of the US, as there have been no regularisation programmes in recent decades, illegality has turned into a rather indefinite status. It is true there is always the promise of future legalisations but, without ever materialising, this promise translates into a mechanism of disciplining illegal migrants - by encouraging them to ensure their identifiability and traceability and being 'good' illegal migrants - rather than as a door to legal recognition and permanent residence (see Chauvin \& Garcés-Mascareñas forthcoming). Second, Taiwan and Singapore are examples that would almost tempt one to think that the dream of migration 'management' is possible in some places. In both these countries, the state appears to have managed to regulate and control labour immigration in all three aspects of entry, stay and return (see e.g. Lu 2008). Though a closer look is needed to confirm this conclusion, one might ask here to what extent the 'success' of immigration policies is due to a better balance between markets and citizenship in a context of few rights and high migration control, or to what point, given the insular nature of 
the two places, geography would primarily account for the difference.

\subsection{The state's production of illegality}

Illegal immigration has tended to be explained as a socio-economic phenomenon that just happens, despite migration policies and states. From this standpoint, many scholars have reached the conclusion that socio-economic factors make it difficult, if not impossible, to enforce policy restrictions. The next conclusion has been that states have failed to control migration flows or that they simply do not have the capacity to do so (Cornelius et al. 2004). In contrast with these approaches, this study makes clear that illegal immigration is not an independent phenomenon that simply occurs, whatever the state or its immigration policies. While immigrant flows are indeed motivated by the importance of the structurally embedded demand for foreign workers in different receiving societies and of cross-national economic disparities and transnational economic, social and historical ties, these factors alone do not explain why a significant part of these flows takes place illegally. The option (or the opportunity) to migrate legally or illegally cannot be understood without taking into account the obvious factor of the state and its migration policies. This is not only because it is the state that defines who may or may not enter, but also because the state itself produces the migrants' illegality.

In speaking of the state's production of illegality, I do not mean, as other authors have argued (see e.g. Calavita 2005), that the non-legal recognition of the immigrant's existence and work seeks to create a cheap, flexible labour force. It is true that borders might be instrumental in this. As Sassen (I988:7) observes, border enforcement facilitates 'the extraction of cheap labour by assigning criminal status to a segment of the working class - illegal immigrants'. The case of Spain is, in fact, a very clear example. Yet the state's production of illegality is much more than this. It is linked with the intractable antagonism between demands for foreign labour and demands for closure. Attempts were made to find a solution to the dilemma in both Spain and Malaysia by means of an aforementioned gambit of 'the illusion of migration management' and the conviction or intention that foreign labour can be 'imported', controlled, limited and, where necessary, 'exported' at will. However, labour is not, and never has been, just a commodity. In neither of the two cases, with or without rights, has the state succeeded in commodifying foreign labour. The first and foremost result of this 'failed' attempt has been the production of the illegal immigrant or what others (see Cornelius et al. I994, 2004) have dubbed the gap between migration policies and outcomes.

In Malaysia, illegality has been the result, first, of a bureaucratised and commercialised border. Entering Malaysia as a foreign worker has in- 
volved a great deal of red tape and paying out for an endless series of papers to the governments in countries of origin as well as the Malaysian embassies. Moreover, the existence of a chain of intermediaries has only increased the costs of a journey, which, for people just across the border, are exorbitant and unnecessary. Due to the bureaucratisation and commercialisation of the border, illegal entry has represented for would-be immigrants in nearby zones a much faster and cheaper option. Second, as I have mentioned, control over immigrants has clashed with the interests of employers who want a more flexible as well as permanent workforce. Then again, there is immigrants' resistance to being turned into mere manpower in thrall of the state's interests.

In Spain, the state's production of illegality resulted from two different processes. First, as already noted, the mismatch between the economics and politics of migration led to nothing less than an outright model of illegal immigration. This discrepancy is related to restrictionist national interest, but also with a bureaucracy that was unable to cope with burgeoning, 'unforeseen' requests for entry. Second, the policy of periodical regularisations both reduced and produced illegality. If each regularisation campaign was launched with the aim of taking the illegality count back to zero, each regularisation process produced new or recurrent illegality. This must be explained by the fact that, until 200I, time of residence rather than holding a job was the main requisite for regularisation while, with the first renewal after a year, having a job, not residence, was the chief requirement for maintaining legal status. What ended up creating illegality, then, was the combination of relative (though deferred) open entry by means of regularisation and the preservation of a form of conditioned membership. In other words, illegality - what Spanish scholars have called 'relapse into illegality' - was the aftermath of a regularisation policy that applied to residents and a renovation policy that only covered workers with a (formally recognised) job.

It could be asserted that any kind of regulation entails its opposite or, to put it slightly differently, legality bears the seeds of illegality within it. While this may be true, there is more to it than that. In particular, this study shows how it is precisely 'the illusion' of considering and treating immigrants as mere workers - as manpower that can be imported, kept under constraints and exported at will - that produces this illegality. The reason for this is simply that immigrants are more than merely braceros 'arm' men - or a commodity that can be subjected to barriers, tariffs and limits. This does not mean that borders and state control do not matter. In fact, illegality is proof of their existence and relevance. It means, rather, that illegality - and this is the main thrust of my argument - should not be explained in outside terms but from within, from the context of immigration policy itself and the contradictions besetting the nation-state with regard to labour demands. Here, the historical perspective throws some 
light on the matter. If one compares the cases of Malaysia and Spain with the earliest forms of world labour transfer (basically to the colonies), there are three outstanding differences that also reveal why labour demands tend to produce illegality in the context of modern nation-states.

First, during colonial times, the contradiction between the politics and economics of migration that may nowadays appear (as in the case of Spain) did not arise. Second, although the colonial situation was essentially one of forced labour and forced migration, the immigrants arrived in the country to stay. As noted in the first chapter of this book, slaves belonged to an employer until the end of their days, while indentured workers were generally encouraged to stay on after their contracts expired. Third, those who emigrated outside (or who left) the state-regulated migration system (for example, the Chinese in colonial Malaya) were not located outside the law. In other words, irregularity - being outside the regular system - did not mean illegality (see Garcés-Mascareñas 2008a). These three differences - the fact that as many workers as needed were allowed to enter, indefinitely and independently of whether they migrated within or outside the state-regulated system - are essentially explained because the presence of these workers never represented any challenge to the polity. Their presence gave them no access to membership. It was precisely because of this that as many people as were required by employers could enter and even stay for good.

In contrast, sovereignty led to an identification of community or polity with territory. Accordingly, the entry of foreigners into the territory was seen as a potential threat to the economic, social, political and cultural boundaries. In the context of the nation-state, migrants have been seen as competing with local workers, as a burden on the welfare state and its limited distributive power, as non-legitimate voters or as cultural aliens. As I remarked at the outset, a tendency towards universalist inclusion within nation-states is intrinsically interlocked with systematic exclusion of people classified as non-members, non-citizens or foreigners (Bader I995: 2I2). The key question has been how to achieve this exclusion in the face of huge labour demands. In Malaysia, the attempt was made by imposing the exclusion from within: letting them in, but only as temporary foreign workers with few rights. In Spain, exclusion was imposed at the point of entry and during the first years of residence. However, as this study shows, the balance between inclusion and exclusion has always been shaky: in Malaysia this is because it has not been easy to restrict and control migrants' presence in the country; in Spain, because the markets are unwilling to do without migrant workers and because migrants tend to stay on even when they have not fulfilled the function assigned to themthat is, that of being formally employed workers. In both cases, this everprecarious equilibrium between inclusion and exclusion is precisely the bottom-line when it comes to explaining illegality. 


\subsection{Meanings of illegality}

The literature on migrant illegality, as we saw in chapter I, presents different approaches. Some scholars analyse the implications of legal exclusion with regard to illegal immigrants' lives. These writers speak, for example, of how the category of 'illegal' tends to construct a subordinate labour force, pure manpower without access to social services and facilities, non-legal subjects or 'bare life' excluded from legal existence (Agamben I998). Other scholars bring out the ways in which illegal immigrants are incorporated through informal, everyday practices. This strand of the literature is concerned with how individual and collective coping strategies of the migrants themselves, NGOs and sympathetic civil servants have paved the way for an opening up of loopholes for illegal immigrants on the job market or in the realm of the welfare state. This book is a blend of both types of research.

With regard to the first set of scholars, suffice to say that illegality does not always mean confinement to a subordinate identity or imprisonment within the bounds of non-recognition. Better said, it is not always more the case than it is with legality. As I have reiterated throughout this study, in Malaysia, the resort to illegality by people who entered the country illegally and those who became illegal immigrants on leaving their employers has made it possible to 'escape' the restraints imposed by the state-regulated migrant labour system. Illegal immigrants, unlike 'legal' immigrants, can change jobs, to some extent negotiate their salary and working conditions, enter or remain in the country without paying extra and prolong their stay regardless of the economic situation, their state of health or whether their five years stipulated by law is up. This resort to illegality is not unique to the Malaysian case. There were the 'spontaneous migrants' to Northern Europe in the I960s and early I970s and the Eastern European migrants recruited by commercial employment agencies from the late I990s onwards who found themselves in extreme coercive situations. They also escaped restrictions imposed by the migrant labour system by migrating or looking for work on their own. In all such circumstances, illegality constitutes a form of resistance - one not so different from the kinds of resistance adopted by Malay peasants in colonial times, as described by Scott (I985). This resistance is not organised or collective by nature. Neither is it verbalised or staged in any way. Rather, it is carried out on the basis of small, everyday, individual actions, leading an invisibleor 'invisibilised' - existence that precisely as such contrives to escape from, and thereby reveal itself to, state control.

As for the dichotomy between exclusion in the formal sphere and inclusion in the informal one, the Spanish case is paradigmatic in the way its legal system at once excludes and includes. By this I mean the way in which the tension between illegal status and certain citizenship rights 
does not always set up an opposition between formal law, on the one hand, and informal practices, on the other: it is also located within the law itself (Chauvin \& Garcés-Mascareñas forthcoming). First of all, while illegal immigrants are undocumented on the national level (by the central government), their registration in el Padrón gives them documents at the local level. Second, while legal and, particularly, political processes were including illegal immigrants in some spheres of the social domain, in terms of work, they still fell into the category of legally non-existent, and hence right-less manpower. This flexible line between exclusion and inclusion, between outside and inside, reveals how illegality should be understood as a differentiated form of inclusion rather than as absolute shutting-out. Furthermore, it makes it possible to identify the more sheltered aspects of citizenship. In the Spanish case, it would seem clear that the dividing lines that affect illegal immigrants are much less permeable in the national domain and with respect to the labour market than they are in the local domain and with respect to the welfare state.

Finally, if we compare the meanings of illegality in Malaysia and Spain, it is important to identify a number of major differences and similarities. If illegality is defined as an in-between state of regularisability (the potential of being regularised) and deportability (the potential of being deported), we could conclude that the situation of illegal immigrants would tend more to deportability in Malaysia and more to regularisability in Spain. Related to this, another difference between the two countries appears with the relationship between legality and illegality. In Malaysia, illegality should be understood, above all, as an alternative to legality with regard to both arrival and stay. Moreover, illegality tends to represent a cul-desac in terms of rights and legal recognition. In contrast with Malaysia, illegality in Spain has ended up representing a transition, path or requisite for legality. Despite these fundamental differences, both cases make it clear how legal status and illegal status are not fixed. On the contrary, immigrants move from one status to the other (from legality to illegality in Malaysia, and from illegality to legality and vice versa in Spain) with relative ease. Finally, in both cases, one can see that to speak of illegality is also to speak of what might be called the theatre of illegality - which is to say, the staging of migratory control over the illegal immigrant (De Genova 2002: 436).

As De Genova (ibid.: 436- 437) has demonstrated for the US, this show of migratory control is mainly carried out by means of arrests, detentions and deportations. Through deprivation of free movement and forced physical expulsion state control is deployed in its most heightened expression. If, in the labour sphere, the illegal immigrant is stripped of his or her rights as a worker, with deportation he or she is directly dispossessed of freedom of movement (De Genova 2009). The aim of deportation policies is not so much to reduce illegal immigration as it is to delimit a 
symbolic precinct of illegality. While this is common to both Malaysia and Spain, the basic difference between the two countries is to be found in the space where the show of illegality is staged. In Malaysia, deportation policies are practised in the very heart of national territory. In Spain, they are particularly carried out on the geographic frontier and beyond. This difference between the geographies of deportability suggests that the deportees are different in each case. In Malaysia, essentially workers are deported, while in Spain deportation is mostly applied - and one might almost say in a preventive fashion - to those who have not yet managed to get in.

\subsection{Towards a theory of borders and confines}

This comparison between two such different countries - what some would call a comparison of the incomparable - has aimed to trace relationships and deconstruct categories that are too often taken for granted in particular historical and national contexts. First, the comparison has shown how the trilemma between markets, citizenship and rights develops differently in liberal and non-liberal states although with unexpected and relevant similarities as well. For instance, in both cases, markets have ruled. In both cases, demands for closure were met by attempting to block access to membership. In both cases, the state illusion of migration management and, in more general terms, the intractable antagonism between the demands of markets and the demands of citizenship, or those for foreign labour and those for closure, have produced illegal migration. Second, the comparison has revealed that, contrary to what it is assumed from a Western perspective, illegal migration does not mean the same everywhere. Illegality mirrors the contours of legality and, in those places where these contours are very narrow, illegality therefore does not necessarily mean a more subordinated form of existence. Finally, although this goes beyond the scope of this research, the comparison shows how borders act in very different ways or, to be more specific, have various implications and meanings when considered in the light of migratory flows.

In these closing paragraphs, I should like to sketch by way of conclusion what we might call an incipient theory of borders and confines. By border I understand the territory where one state ends and another begins, the geographic line between different states. By confine I mean, using Mezzadra's (2005: II2; original in Spanish) term, the 'line of division and protection of constituted and consolidated political, social and symbolic spaces'. Comparing borders and confines, I have the impression - which is not to be taken as any kind of conclusion, but rather as a window looking out onto future research - is that in Malaysia it is the confine and in Spain it is the border that is engraved on the immigrant experience. 
Malaysia's geographic border is not erected as a wall separating those inside from outside. Via the country's airports or aboard small boats, legal and illegal immigrants cross the country's borders without much difficulty. Once they are inside, however, the confine is imposed on both groups. For legal immigrants, the confine is established when they are immobilised in the job market, made dependent on their employers and defined as purely and exclusively temporary labour. The confine of legality is marked by reducing legal immigrants to the condition of being mere 'foreign workers'. As for illegal immigrants, the confine is constructed over the threat of deportation or being physically 'expelled' from national territory in a more or less judicial and arbitrary fashion.

In this regard, I would conclude as argued elsewhere (Garcés-Mascareñas 20Iо), that what marks the experience of immigrants in Malaysia is not so much crossing the border (legally or illegally), but rather being on the outside even when physically inside. This may be explained by referring to two different factors. First, we should once more refer to the rights factor. As recalled throughout this book, because rights can be highly restricted, the state of Malaysia has been able to implement a policy of letting migrants in, albeit only as temporary foreign workers. In other words, the border to legal entry could be minimised since the confine would be awaiting legal migrants inside. Second, the ease of illegally crossing the border should be explained by the fact that this frontier does not work as an impenetrable wall between different worlds. As observed earlier, border territories of post-colonial states have largely remained at a great remove from the interests of the national elites installed in the centre. The elites' indifference towards these regions explains why most migration control takes place in the heart of the nation-state (Peninsular Malaysia and particularly Kuala Lumpur) instead of at the geographic border. Therefore, in contrast to what we increasingly see in Western countries, the experience of being identified - and named - as an unwanted outsider does not take place when the immigrant is en route or trying to 'get in', but when he or she is in the heartland of the national territory.

In Spain - and this point can be extended to most Western countries it is especially on the border where the largest-scale, most frequent forms of exclusion occur. It is at the border, and beyond it in the countries of origin, where the meagre trickle of those who may enter are separated from those who may not, or where those who seem to be trying to get in are anyway rejected and turned back. In contrast with Malaysia, it is especially on the border where not only the illegality show is staged, but also the ultimate performance of immigration policies. As I have observed throughout this book, the border's dominance over the confine is a form of excluding immigrants where exclusion is still possible-which is to say, where the state can still get around the constraints imposed by the legal and political systems. From this point of view, we might conclude that the 
relationship between border and confine is connected with the nature of the state (post-colonial state versus old nation-state), the market factor in migration policymaking processes (favouring the entry of workers or not) and the role played by rights (and their application) within national territory. Regarding the last aspect, it would be facile to conclude, however, that the confine is characteristic of non-democratic or autocratic countries while the border is imposed as the only form of exclusion in liberal democracies. In short, it is not a question of either/or.

Several reasons could be argued here. Whether entering by sea, through the Pyrenees Mountains or simply with a tourist visa on arrival, Spain's borders have been much more porous than one would expect from the mainstream discourse of Fortress Europe. The present study shows how in Spain there are also significant confines that affect both legal and illegal immigrants. The difference with Malaysia does not lie so much in the existence or absence of the confine, but rather in its duration. As I have noted in the last few pages, the important fact is not that, in Spain, there has been no exclusion from within, but that it has only been possible to enforce this exclusion during the first years in the country. In the long term, both legal and illegal immigrants have ended up being recognised as permanent residents or fully fledged citizens. Finally, several studies (Balibar 2005; Bigo 2002; Salter 2004; Mezzadra 2005; Walters 2006) have signalled a tendency towards 'de-localisation', 'de-territorialisation' and 'disegregation' from the border inwards. Along with the reinforcement of exterior walls and the externalisation of the border towards the countries of origin, new borders within the space of the nation-state are under construction. It remains to be seen how far this exclusion from within will go and to what extent - in a growing climate of securitisation and anti-immigrant discourses - the rule of law and its accompanying rights will matter. 


\section{References}

Anderson, B. (1983), Imagined communities: Reflections on the origin and spread of nationalism. London: Verso.

Agamben, G. (1998), Homo sacer: Sovereign power and bare life. Stanford: Stanford University Press.

Aguilera Izquierdo, R. (2006), 'El acceso de los inmigrantes irregulares al mercado de trabajo: Los procesos de regularización extraordinaria y el arraigo social y laboral', Revista del Ministerio de Trabajo y Asuntos Sociales 63: I75-I94.

Aja, E. (2006), 'La evolución de la normativa sobre inmigración', in E. Aja \& J. Arango (eds.), Veinte años de inmigración en España: Perspectiva jurídica Y sociológica (1985-2004), I7-47. Barcelona: CIDOB.

Andaya, B. \& L. Andaya (I982), A history of Malaysia. London: Macmillan Asian Histories Series.

Amin, I. (I988), 'Labour migration in the plantation industry: Employers' point of view', Current issues in labour migration in Malaysia, Kuala Lumpur.

Amnesty International (I997), AI Report I997. www.amnesty.org/ailib/aireport/ ar97/ASA28.htm. Accessed ro October 2009.

Aparicio Wilhelmi, M. \& E. Roig Molés (2006), 'La entrada por razones laborales y el trabajo de los extranjeros: El progresivo desarrollo de un sistema ordenado de entrada laboral', in E. Aja \& J. Arango (eds.), Veinte años de inmigración en España: Perspectiva jurídica y sociológica (1985-2004), I45-I75. Barcelona: CIDOB.

Aragón Bombín, R. (I996), 'Diez años de política de inmigración: Implicaciones de las distintas áreas de gestión: Educación, cultura, salud, vivienda, empleo y servicios sociales', Migraciones o: 45-6o.

Aragón Bombín, R. (I995), 'Política migratoria e inmigración marroquí en España', in J.B. Vilar (ed.), Murcia: Frontera demográfica en el Sur de Europa, I03-II6. Murcia: Universidad de Murcia.

Aragón Bombín, R. (I993), 'Migration and international co-operation: Challenges for OECD countries', paper presented at the OECD conference Migration and International Co-Operation: Challenges for OECD Countries, Madrid, 29-3I March I993.

Aragón Bombín, R. \& J. Chozas Pedrero (I993), La regularización de inmigrantes durante 1991-1992. Madrid: Ministerio de Trabajo y Seguridad Social.

Arango, J. (2003), 'Dificultades y dilemas de las políticas de inmigración', Circunstancia. Revista de Ciencias Sociales del IUIOG I (2): 3-7.

Arango, J. \& R. Sandell (2004), Inmigración: Prioridades para una nueva política española. Madrid: Instituto Universitario Ortega y Gasset.

Arango, J. \& L. Suárez Navaz (2002), La regularización de extranjeros del año 2000. Madrid: Centro para el Estudio de las Migraciones y la Ciudadanía, Instituto Universitario Ortega y Gasset. 
Asian Migrant Centre (I999), Asian migrant yearbook 1999: Migration facts, analysis and issues in 1998. Hong Kong: Asian Migrant Centre.

Asociación Pro Derechos Humanos de Andalucía (2007), Derechos humanos en la frontera sur 2006. www.proasyl.de/fileadmin/proasyl/.../informeinmigrazoo6. doc. Accessed 5 October 2009.

ASTI (I99I), 'Propuestas sobre regularización de extranjeros'. Madrid: Delegación Diocesana de Migraciones-ASTI.

Babiano, J. \& A. Fernández Asperilla (2002), El fenómeno de la irregularidad en la emigración española de los años sesenta. Madrid: Fundación Iํ de Mayo.

Bach, R.L. (1978), 'Mexican immigration and the American state', International Migration Review I2: 536-558.

Bader, V. (2005), 'The ethics of immigration', Constellations I2 (3): 33I-360.

Bader, V. (I995), 'Citizenship and exclusion: Radical democracy, community and justice. Or, what is wrong with communitarism?', Political Theory 23 (2): 2II-246.

Bagoes Mantra, I. (I999), 'Illegal Indonesian labour movement from Lombok to Malaysia', Asia Pacific Viewpoint 40 (I): 59-68.

Baldwin-Edwards, M. \& A. Kraler (2009), Regularisations in Europe: Study on practices in the area of regularization of illegally staying third-country nationals in the member states of the EU. Vienna: ICMPD.

Bauböck, R. (1994) Transnational citizenship: Memberships and rights in international migration. Aldershot: Edward Elgar.

Balibar E. (2005), Europe constitution frontière. Bègles: Editions du Passant.

Battistella, G. (2002), 'Unauthorized migrants as global workers in the ASEAN Region', Southeast Asian Studies 40 (3): 350-37I.

Beeman, M.A. (I985), The migrant labor system: The case of Malaysian rubber workers, PhD dissertation, University of Illinois.

Bentolila, S. \& O. Blanchard (I992), 'Spanish unemployment', Economic Policy Io: 233-265.

Berger, J. \& J. Mohr (I975), A seventh man. Baltimore: Penguin.

Bigo, D. (2002), 'Security and immigration: Toward a critique of the governmentality of unease', Alternatives 27 (I): 63-92.

Bloch, M. (I953), 'Toward a comparative history of European societies', in F.C. Lane \& J.C. Riemersma (eds.), Enterprise and secular change: Readings in economic history, 494-521. London: Allen \& Unwin.

Bosma, U. (2004), 'Citizens of empire: Some comparative observations on the evolution of creole nationalism in colonial Indonesia', Comparative Studies in Society and History 46 (4): 656-68I.

Boswell, C. (2007), 'Theorizing migration policy: Is there a third way?', International Migration Review 4I (I): 75-I00.

Bover, O. \& P. Velilla (I999), 'Migration in Spain: Historical background and current trends', Discussion Paper Series 88, December 1999.

Brettell, C-B. \& J.F. Hollifield (2000), Migration theory: Talking across disciplines. New York: Routledge.

Brochmann, G. \& T. Hammar (eds.) (I999), Mechanisms of immigration control: A comparative analysis of European regulation policies. Oxford: Berg.

Brown, D. (2002), The state and ethnic politics in South-East Asia. London/New York: Routledge.

Brubaker, R. (I995), 'Comments on "Modes of immigration politics in liberal democratic states"', International Migration Review 29 (4): 903-908. 
Brubaker, R. (1992), Citizenship and nationhood in France and Germany. Cambridge: Harvard University Press.

Bullón Fernández, R. (I9I4), El problema de la emigración y los crímenes de ella: Orientaciones más convenientes para la política económica de España. Barcelona: Casa Provincial de Caridad.

Bruquetas-Callejo, M., B. Garcés-Mascareñas, R. Morén-Alegret, R. Penninx \& E. Ruiz-Vieytez (2008), 'Immigration and integration policymaking in Spain', IMISCOE working paper no. 2I. http://library.imiscoe.org/en/record/2709I7.

Bustamante, J.A. (I976), Espaldas mojadas: Materia prima para la expansión del capital norteamericano. México: El Colegio de México.

Burawoy, M. (1976), 'Structural and ideological conditions of Mexican undocumented immigration to the United States', American Behavioral Scientist I9 (3): $364-376$.

Cabellos Espiérrez, A. \& E. Roig Molés (2006), 'El tratamiento jurídico del extranjero en situación regular', in E. Aja \& J. Arango (eds.), Veinte años de inmigración en España. Perspectiva jurídica y sociológica (1985-2004), II3-I29. Barcelona: CIDOB/Edicions Bellaterra.

Cachón, L. (2009), La España inmigrante: Marco discriminatorio, mercado de trabajo y políticas de integración. Madrid: Anthropos.

Cachón, L. (2008), 'La experiencia internacional en regularizaciones extraordinarias de inmigrantes indocumentados: España en el modelo del sur de Europa', powerpoint presentation.

Cachón, L. (2004), 'Inmigracion y mercado de trabajo en España', Economia Exterior 28: $49-57$.

Cachón, L. (2003), 'La Inmmigración en España: Los desafíos de la construcción de una nueva sociedad', Migraciones I4: 219-304.

Cachón, L. (2002a), 'La formación de la "España inmigrante”: Mercado y ciudadanía', Revista Española de Investigaciones Sociológicas 97: 95-I26.

Cachón, L. (2002b), 'Inmigración y segmentación de los mercados de trabajo en España', Documentos de Trabajo, 2003/2002. Fundación Centro de Estudios Andaluces.

Cachón, L. (I997), 'Segregación sectorial de los inmigrantes en el mercado de trabajo en España', Cuadernos de Relaciones Laborales io. Madrid: UCM.

Cachón, L. (I995), 'Marco institucional de la discriminación y tipos de inmigrantes en el mercado de trabajo en España', Revista Española de Investigaciones Sociológicas 69: I05-I24.

Calavita, K. (2005), Immigrants at the margins: Law, race and exclusion in Southern Europe. Cambridge: Cambridge University Press.

Calavita, K. (I992), Inside the state: The Bracero Program, immigration and the INS. New York/London: Routledge.

Calavita, K. (I990), 'Employer sanctions violations: Toward a dialectical model of white-collar crime', Law and Society Review 24 (4): 104I-I069.

Calavita, K. (1989), 'Recent works on immigration policymaking: A review essay and agenda for the future', Law and Society Review 23 (5): 799-820.

Calavita, K. (I984), US immigration law and the control of labor, 1820-1924. London: Academic Press.

Carmona, J. \& J. Simpson (2003), El laberinto de la agricultura española: Instituciones, contratos y organización entre 1850 y 1936. Zaragoza: Prensas Universitarias de Zaragoza. 
Casey, J. (I998), 'Las políticas de inmigración: La regulación de admisión y la acción integradora', in J. Subirats \& R. Gomá (eds.), Las políticas públicas en España. Contenidos, redes de actores y niveles de gobierno, 3I7-34O. Madrid: Ariel.

Castells, M. (I975), 'Immigrant workers and class struggles in advanced capitalism: The Western European experience', Politics and Society 5 (I): 33-66.

Castles, S. (1993), 'Migrations and minorities in Europe: Perspectives for the I990s: Eleven hypotheses', in J. Wrench \& J. Solomos (eds.), Racism and migration in Western Europe, I7-34. Oxford: Berg Publishers.

Castles, S. (I986), 'The guest-worker in Western Europe: An obituary', International Migration Review 20 (4): 76I-778.

Castles, S. \& Kossack, G. (I973), Immigrant workers and class structure in Western Europe. Oxford: Oxford University Press.

Chang, G. (2006), 'Disposable domestics: Immigrant women workers in the global economy', in M.K. Zimmerman, J.S. Litt \& C.E. Bose (eds.), Global dimensions of gender and carework, 39-48. Stanford: Stanford University Press.

Chang, G. (2000), Disposable domestics. Cambridge: South End Press.

Chauvin, S. \& B. Garcés-Mascareñas (forthcoming), 'Beyond informal citizenship: The moral economy of migrant illegality in cross-national perspective', International Political Sociology 6.

Chelliah, S.J. (I988), 'Problems of migrant and immigrant workers in the plantation industry: Employers' point of view', Current issues in labour migration in Malaysia. Kuala Lumpur.

Chin, C. (2002), "The "host" state and the "guest" worker in Malaysia: Public management of migrant labour in times of economic prosperity and crisis', Asia Pacific Business Review 8 (4): 19-40.

Chin, C. (2000), 'The state of the state in globalization: Social order and economic restructuring in Malaysia', Third World Quarterly 2I (6): I035-1057.

Chin, C. (I998), In service and servitude: Foreign female domestic workers and the Malaysian 'modernity' project. New York: Columbia University Press.

Chin, C. (I997), 'Walls of silence and late twentieth century representations of the foreign female domestic workers: The case of Filipina and Indonesian female servants in Malaysia', International Migration Review 3I (2): 94-97.

Cohen, D. (2004), 'Comparative history: Buyer beware', in D. Cohen \& \& O'Connor (eds.), Comparison and history: Europe in cross-national perspective, 23-33. New York: Routledge.

Consejo Económico y Social (2004), La inmigración y el mercado de trabajo en España. Madrid: Consejo Económico y Social.

Consejo General de la Abogacía Española (2006), 'Informe sobre la problemática de la asistencia letrada en las fronteras interiores Schengen'. http://intermigra.info/ extranjeria/informefronteras.pdf. Accessed ig November 2010.

Cornelius, W.A. (2005), 'Controlling “unwanted” immigration: Lessons from the United States, I993-2004', Journal of Ethnic and Migration Studies 3I (4): 775-794.

Cornelius, W.A. (2004), 'Spain: The uneasy transition from labor exporter to labor importer', in W.A. Cornelius, T. Tsuda, P.L. Martin \& J.F. Hollifield (eds.), Controlling immigration: A global perspective, 387-429. 2nd ed. Stanford: Stanford University Press.

Cornelius, W.A., P.L. Martin \& J.F. Hollifield (2004 [I994]), Controlling immigration: A global perspective. Stanford: Stanford University Press. 
Cornelius, W.A. \& T. Tsuda (2004), 'Controlling immigration: The limits of government intervention', in W.A. Cornelius, P. Martin \& J. Hollifield (eds.), Controlling immigration: A global perspective, 3-48. 2nd ed. Stanford: Stanford University Press.

Coutin, S.B. (2005), 'Contesting criminality: Illegal immigration and the spatialization of legality', Theoretical Criminology 9: 5-33.

Coutin, S.B. (2000), Legalizing moves: Savadoran immigrants' struggle for US residency. Ann Arbor: University Michigan Press.

Coutin, S.B. (1996), 'Differences within accounts of U.S. immigration law', PoLAR I9 (I): II-2O.

Cross, G.S. (1983), Immigrant workers in industrial France: The making of a new labouring class. Philadelphia: Temple University Press.

De Genova, N. (2009), 'The deportation regime: Sovereignty, space, and the freedom of movement', in N. De Genova \& N. Peutz (eds.), The deportation regime: Sovereignty, space, and the freedom of movement, 33-65. Durham: Duke University Press.

De Genova, N. (2002), 'Migrant "illegality" and deportability in everyday life', Annual Review of Anthropology 3I: 4I9-447.

De Lange, T. (2007), Staat, markt en migrant: De regulering van arbeidsmigratie naar Nederland 1945-2006. Nijmegen: Boom Juridische uitgevers.

Department of Immigration, Malaysia (I998), Annual Report.

Detienne, M. (2004), Comparer l'incomparable. Paris: Seuil.

Dorall, R. (I989), 'Foreign workers in Malaysia: Issues and implications of recent illegal economic migrants from the Malay world', in Asian Pacific and Development Center (ed.), The trade in domestic helpers: Causes, mechanisms and consequences. Kuala Lumpur: Asian and Pacific Development Centre.

Emerson, R. (I964), Malaysia: A study in direct and indirect rule. Kuala Lumpur: University of Malaya Press.

Ezquerra, S. (2008), The regulation of the South-North transfer of reproductive labor: Filipino women in Spain and the United States. Dissertation presented to the Department of Sociology, University of Oregon.

Ezquerra, S. \& B. Garcés-Mascareñas (2008), 'Towards transnationalism from above: The case of the Philippine state in Malaysia', paper presented at the International Sociological Association conference, Barcelona, 7-8 September 2008.

Faist, T. (2000), 'Lacunae of migration and post-migration research', in T. Faist (ed.), The volume and dynamics of international migration and transnational social spaces, I-29. Oxford: Clarendon Press.

Fernandez, I. (I997), 'Migrant workers and employers in Malaysia', Asian Migrant Io (3): 94-97.

Fernández Suárez, B. (2007), 'La política de admisión en materia de extranjería: El impacto sobre el flujo de inmigración latinoamericana hacia España', paper presented at the conference Conmemoración de los 50 Años de la Facultad Latinoamericana de Ciencias Sociales (FLACSO), Quito, 29-3I October 2007.

Ferrero, R. \& G. Pinyol (2007), 'El reto de la inmigración irregular: Los procesos de regularización en Europa', paper presented at the Congreso sobre la Inmigración en España. Valencia, 2I-24 March 2007.

Finotelli, C. (2007), 'Italia, España y el modelo migratorio mediterráneo en el siglo XXI', ARI 58. Madrid: Real Instituto Elcano. 
Ford, M. (2006), 'After Nunukan: The regulation of Indonesian migration to Malaysia', in A. Kaur \& I. Metcalfe (eds.), Mobility, labour migration and border controls in Asia, 228-247. Hampshire: Palgrave Macmillan.

Freeman, G.P. (I986), 'Migration and the political economy of the welfare state', Annals, AAPSS 485: 5I-63.

Freeman, G.P. (1995), 'Modes of immigration politics in liberal democratic states', International Migration Review 29 (4): 88I-902.

Froebel, F., O. Kreye \& J. Heinrichs (I980), The new international division of labour: Structural unemployment in industrialized countries and industrialization in developing countries. Cambridge: Cambridge University Press.

Gabinet d'Estudis Socials (GES) (2002), 'La contratación en origen de trabajadores extranjeros en la Unió de Pagesos'. www.gabinet.ath.cx/downloads/ ContrataOrigen.pdf. Accessed 3 November 2009.

Galarza, E. (1964), Merchants of labor: The Mexican Bracero story. California: McNally $\&$ Loftin.

Garcés-Mascareñas, B. (20I0), 'Fronteras y confines de un estado post-colonial: El caso de Malasia', in M.E. Anguiano \& A. López Sala (eds.), Migraciones $y$ fronteras: Estudios de caso y aproximaciones metodológicas, 259-279. Barcelona: Icaria/ CIDOB.

Garcés-Mascareñas, B. (2008b), 'Producing irregularity, constructing illegality, deporting migrants: Migration policies in Malaysia', paper presented at the ASEF workshop 'Now you see them, now you don't: Defining irregular migrants in Europe and Asia and the immigration measures applied to them', Kuala Lumpur, 7-9 January 2008.

Garcés-Mascareñas, B. (2008a), 'Continuities and discontinuities of labour migration regulations in Malaysia: From colonial times to the present', in M. Schrover, J. Van der Leun, L. Lucassen \& C. Quispel (eds.), Gender and illegal migration in a global and historical perspective, I05-I26. IMISCOE Research Series. Amsterdam: Amsterdam University Press.

Garcés-Mascareñas, B. (2004), The creation of temporary labour schemes: A comparison between guestworker programs in the United States, Western Germany, Malaysia and Kuwait. Master's thesis, University of Amsterdam.

Garrido Medina, L. (2003), Para cuantificar a los extranjeros. www.ced.uab.es/jperez/ PDFs/Garridoo3.pdf. Accessed 3 November 2009.

Glick Schiller, N., L. Basch \& C.S. Blanc (I995), 'From immigrant to transmigrant: Theorizing transnational migration', Anthropological Quarterly 68 (I): 48-63.

Glick Schiller, N., L. Basch \& C.S. Blanc (I992), 'Transnationalism: A new analytic framework for understanding migration', Annals of the New York Academy of Sciences 645: I-24.

González, L.E. \& R. MacBride (2000), 'Fortress Europe: Fear of immigration? Present and future of immigration law and policy in Spain', UC Davis Journal of International Law and Policy 6 (2): I53-I9I.

González-Enríquez, C. (2009), 'Spain, the cheap model: Irregularity and regularisation as immigration management policies', European Journal of Migration and Law II: I39-I57.

Green, N.L. (I997), 'The comparative method and poststructural structuralism: New perspectives for migration studies', in J. Lucassen \& L. Lucassen (eds.), Migration, migration history, history: Old paradigms and new perspectives, 4I-56. Bern: Peter Lang AG. 
Groenendijk, K. \& R. Hampsink (I995), Temporary employment of migrants in Europe. Nijmegen: Reeks Recht \& Samenleving.

Guiraudon, V. (2002), 'The constitution of a European immigration policy domain: A political sociology approach', Journal of European Public Policy Io (2): 263-282.

Guiraudon, V. (2000), 'The Marshallian triptych reordered: The role of courts and bureaucracies in furthering migrants' social rights', in M. Bommes \& A. Geddes (eds.), Immigration and welfare: Challenging the borders of the welfare state, 72-89. London: Routledge.

Guiraudon, V. (1998), 'Citizenship rights for non-citizens: France, Germany and the Netherlands', in C. Joppke (ed.), Challenge to the nation-state: Immigration in Western Europe and the United States, 272-318. New York: Oxford University Press.

Gurowitz, A. (2000), 'Migrant rights and activism in Malaysia: Opportunities and constraints', The Journal of Asian Studies 59 (4): 863-888.

Hahamovitch, C. (2003), 'Creating perfect immigrants: Guestworkers of the world in historical perspective', Labour History 44 (I): 69-94.

Halim, F. (I986), 'Capital labour and the state: The West Malaysian case', Journal of Contemporary Asia I2 (3): 259-80.

Hammar, T. (ed.) (I985), European immigration policy: A comparative study. Cambridge: Cambridge University Press.

Harris, N. (I995), The new untouchables: Immigration and the new world worker. New York: I.B. Tauris Publishers.

Hatton, T.J. \& J.G. Williamson (I994), The age of mass migration: Causes and economic impact. New York: Oxford University Press.

Herbert, U. (I990), A history of foreign labour in Germany, 1880-1980: Seasonal workers/forced laborers/guest workers. Ann Arbor: University of Michigan Press.

Hollifield, J. (2005), 'The emerging migration state', in I. Toshio \& I. Masako (eds.), Motion in place / place in motion, I9-44. JCAS Symposium Series 22. Osaka: The Japan Center for Area Studies.

Hollified, J. (2004), 'Migration and international relations: The liberal paradox', in H. Entzinger, M. Mariniello \& C. Wihtol de Wenden (eds.), Migration between states and markets. Aldershot, England: Ashgate.

Hollifield, J. (2000), 'The politics of international migration: How can we bring the state back in?', in C.B Brettell \& J.F. Hollifield (eds.), Migration theory: Talking across disciplines, I32-I60. New York: Routledge.

Hollifield, J. (I992), Immigrants, markets and states: The political economy of postwar Europe. Cambridge: Harvard University Press.

Hugo, G. (I995), 'Labour export from Indonesia: An overview', ASEAN Economic Bulletin I2 (2).

Hugo, G. (I993), 'Indonesian labour migration to Malaysia: Trends and policy implications', Southeast Asian Journal of Social Sciences 2I (I): 36-70.

INE (2007), Nota de prensa sobre Encuesta Nacional de Inmigrantes 2007. www.ine.es/ jaxi/menu.do?type=pcaxis\&path=\%2Ft20\%2Fp3I9\&file=inebase. Accessed 3 November 2009 .

International Bar Council (2000), Justice in jeopardy: Malaysia 2000. www.ibanet. org/misc/pressrel.asp. Accessed ig November 2009.

ISIS (2007), 'Study to review the process and procedures involved in employing foreign maids from Indonesia', Consultancy report commissioned by EPU/ MTEN/NID, Prime Minister's Department.

Izquierdo, A. (2006), 'La inmigración irregular en el cambio de milenio: Una panorámica a la luz de las regularizaciones y de los contingentes anuales de 
trabajadores extranjeros en España', in C. Solé \& A. Izquierdo (eds.), Integraciones diferenciadas: Migraciones en Catalunya, Galicia y Andalucía, 73-88. Barcelona: Anthropos.

Izquierdo, A. (1996), La inmigración inesperada. Madrid: Trotta.

Izquierdo, A. (I989), La inmigración en España. Madrid: Instituto Español de Emigración.

Izquierdo, A. \& B. Fernández Suárez (2006), 'La inmigración en España 2005-2006: Entre la normalización y el flujo de cayucos', in V. Navarro (eds.), La situación social en España, 219-256. Madrid: Editorial Biblioteca Nueva.

Izquierdo, A. \& S. León (2008), 'La inmigración hacia dentro: Argumentos sobre la necesidad de la coordinación de las políticas de inmigración en un Estado multinivel', Política y Sociedad 45 (I): II-39.

Jabardo, M. (I995), 'Etnicidad y mercado de trabajo: Inmigración africana en la agricultura catalana', Perspectiva Social 36: 8I-95.

Jackson, J.C. (I96I), Planters and speculators: Chinese and European agricultural enterprise in Malaya, I756-I921. Kuala Lumpur: University of Malaya Press.

Jenkins, J.C. (I978), 'The demand for immigrant workers: Labor scarcity or social control?', International Migration Review I2 (4): 514-535.

Jimeno, J. \& L. Toharia (I994), Unemployment and labour market flexibility: Spain. Geneva: International Labour Office.

Jomo, K.S. (2003), 'Growth with equity in East Asia', in K.S. Jomo (ed.), Southeast Asian paper tigers? From miracle to debacle and beyond, I96-219. London: RoutledgeCurzon.

Jones, S. (2000), Making money off migrants: The Indonesian exodus to Malaysia. Hong Kong: Centre for Asia Pacific Social Transformation Studies.

Joppke, C. (2005), 'Exclusion in the liberal state: The case of immigration and citizenship policy', European Journal of Social Theory 8 (I): 43-6I.

Joppke, C. (I998a), Challenge to the nation-state: Immigration in Western Europe and the United States. New York: Oxford University Press.

Joppke, C. (I998b), 'Why liberal states accept unwanted immigration', World Politics $50(2): 266-293$.

Kanapathy, V. (2006), 'International migration and labour market developments in Asia: Fine-tuning the policy and institutional framework for managing crossborder labour flows', paper presented at the workshop 'International migration and labour markets in Asia', Tokyo, I7 February 2006.

Kanapathy, V. (2004), 'International Migration and Labour Market Developments in Asia: Economic Recovery, the Labour Market and Migrant Workers in Malaysia', paper presented at the workshop 'International migration and labour markets in Asia', Tokyo, 5-6 February 2004.

Kanapathy, V. (200I), 'International migration and labor market adjustments in Malaysia: The role of foreign labor management policies', Asian and Pacific Migration Journal Io (3-4).

Kassim, A. (2008a), 'Irregular migrants in Malaysia: Explaining their persistence', paper presented at the ASEF workshop 'Now you see them, now you don't: Defining irregular migrants in Europe and Asia and the immigration measures applied to them', Kuala Lumpur, 7-9 January 2008.

Kassim, A. (2008b), 'Assessing the need for foreign workers and its impact on Malaysian economy', paper presented at the National Symposium on Foreign Workers Policy in Malaysia, Kuala Lumpur, 20-22 October 2008. 
Kassim, A. (I998), 'International migration and alien labour employment: The Malaysian experience', Megacities, labour and communications, Singapore: ISEAS.

Kassim, A. (I997), 'Management of foreign labour: A Malaysian experiment' paper presented at the Second Asia Pacific Conference of Sociology, University of Malaya, I8-20 September 1997.

Kassim, A. (1996), 'Labour migration in ASEAN: Issues and problems from the Malaysian perspective', paper presented at the Seventh Southeast Asia Forum, Kuala Lumpur, 3-6 March 1996.

Kassim, A. (I995), 'Foreign workers in Malaysia: An analysis of sanctioned bondage', paper presented at the Regional Conference of the International Council of Psychologists on Psychological Issues in a Growing Global Community, Manila, IO-I2 August I995.

Kassim, A. (I994a), 'Within and beyond the kitchen: The experience of female immigrant workers in Malaysia', paper presented at the conference Linking our Histories: Asian and Pacific Women as Migrants, University of Melbourne, 3 May I994.

Kassim, A. (I994b), 'Foreign labour in Malaysia', in W. Gooneratne, P.L. Martín \& H. Sazanami (eds.), Regional development impacts of labour migration in Asia, 95-II4. United Nation Centre.

Kassim, A. (I993a), 'Immigrant workers in Malaysia: Issues, problems and prospects', in B.H. Lee, \& S. Oorjitham (eds.), Malaysia and Singapore: Experiences in industrialisation and urban development, I-32. Kuala Lumpur: Faculty of Arts and Social Sciences, University of Malaya.

Kassim, A. (I993b), 'The registered and the illegals: Indonesian immigrants in Malaysia' paper presented at the Movement of Peoples in Southeast Asia Seminar organised by PMB-LIPI, Jakarta, I7-I9 February I993.

Kaur, A. (2004), 'Mobility, labour mobilisation and border controls: Indonesian labour migration to Malaysia since I990', paper presented at the I5th Biennial Conference of the Asian Studies Association of Australia, Canberra, 29 June- 2 July 2004 .

Kaur, A. (I999), 'Women's work: Gender and labour relations in Malaysia', Working Papers on Asian Labour, IIAS. www.iisg.nl/clara/publicat/clara6.pdf. Accessed 29 August 20II.

Kejser, L. (2006), 'Illicit transnational movements: Impact and responses in South East Asia', paper presented at the conference Challenges of Global Migration and Forced Displacement, Kuala Lumpur, I-2 August 2006.

King, R., A. Fielding \& R. Black (I997), 'The international migration turnaround in Southern Europe', in R. King \& R. Black (eds.), Southern Europe and the new immigrations, 56-68. Sussex: Sussex Academic Press.

King, R. \& I. Rodríguez-Melguizo (I999), 'Recent immigration to Spain: The case of Moroccans in Catalonia', in F. Anthias \& G. Lazaridis (eds.), Into the margins: Migration and exclusion in Southern Europe, 55-82. Aldershot: Ashgate.

Kyle, D. \& C.A. Siracusa (2005), 'Seeing the state like a migrant: Why so many noncriminals break immigration laws', in W. van Schendel \& I. Abraham (eds.), Illicit flows and criminal things: States, borders, and the other side of globalization, I53-I77. Bloomington: Indiana University Press.

Kymlicka, W. \& W. Norman (I994), 'Return of the citizen: A survey of recent work on citizenship theory', Ethics I04: 352-38I.

Landman, T. (2003), Issues and methods in comparative politics: An introduction. 2nd ed. New York: Routledge. 
Lascoumes, P. \& P. Le Gales (2007), 'Introduction: Understanding public policy through its instruments - From the nature of instruments to the sociology of public policy instrumentation', Governance: An Introduction Journal of Policy, Administration, and Institutions, 20 (I): I-2I.

Laubenthal, B. (2007), 'The emergence of pro-regularization movements in Western Europe', International Migration 45 (3): IOI-I33.

Lee, H.P. (2003), 'Competing conceptions of rule of law in Malaysia', in R. Peerenboom (ed.), Asian Discourses of Rule of Law: Theories and implementation of rule of law in twelve Asian countries, France and the US, 225-249. London/New York: Routledge.

Lijphart, A. (I969), 'Consociational democracy', World Politics 2I (2): 207-225.

Liow, J.C. (2004), 'Malaysia's approach to its illegal Indonesian migrant labour problem: securitization, politics or catharsis?', in IDSS-Ford workshop on nontraditional security in Asia, Singapore, 3-4 September 2004.

Liow, J.C. (2003), 'Malaysia's illegal Indonesian migrant labour problem: In search of solutions', Contermporary Southeast Asia 25 (I): 44-64.

López Sala, A. (2010), 'La nueva arquitectura política del control migratorio en el Sur de Europa', in M.E. Anguiano \& A. López Sala (eds.), Migraciones y fronteras: Estudios de caso $y$ aproximaciones metodológicas, 75-IO2. Barcelona: Icaria/CIDOB.

López Sala, A. (2000), Inmigrantes y estados: La respuesta política ante la cuestión migratoria. El caso español en el contexto de las democracias occidentales. Universidad Complutense de Madrid, PhD dissertation.

Lu, M. (2008), 'Wives, workers or illegal migrants? Migration and immigration policies in Taiwan', paper presented at the ASEF workshop 'Now you see them, now you don't: Defining irregular migrants in Europe and Asia and the immigration measures applied to them', Kuala Lumpur, 7-9 January 2008.

Lucassen, L. (2007), 'Migration and world history: Reaching a new frontier', International Review of Social History 52 (I): 89-96.

Lucassen, L. (2005), The Immigrant threat: The integration of old and new migrants in Western Europe since 1850. Urbana \& Chicago: University of Illinois Press.

Lucassen, L. (I998), 'The Great War and the origins of migration control in Western Europe and the United States (I880-I920)', in A. Bocker, K. Groenendijk, T. Havinga \& P. Minderhoud (eds.), Regulations of Migration: International Experiences, 45-72. Amsterdam: Het Spinhuis.

Marshall, T.S. (I992), Citizenship and social class. London: Pluto Press.

Marzal Yetano, E. (2009), El proceso de constitucionalización del derecho de inmigración. Madrid: Colegio Registradores.

Martin, P. (2000), 'Guest worker programmes for the 2Ist century', Backgrounder, Washington, D.C.: Center for Immigration Studies.

Martin, P. \& M. Teitelbaum (200I), 'The mirage of Mexican guest workers', Foreign Affairs 80 (6): II7-I3I.

Martín Rojo, L. \& T. van Dijk (I998), 'Había un problema y se ha solucionado', in L. Martín Rojo \& R. Whittaker (eds.), Poder decir o el poder de los discursos, I68-229. Madrid: Arrecife Producciones.

Mascareñas, T.M. (I986), 'Puerto Rico en el segle XIX: Quantificació de l'emigració catalana', Master's thesis presented at the Universitat de Barcelona, Facultat de Geografia i Història.

Massey, D.S. (I999), 'International migration at the dawn of the twenty-first century: The role of the state', Population and Development Review 25 (2): 303-322. 
Massey, D.S. (I998), 'March of folly: US Immigration Policy after NAFTA', The American Prospect 9 (37): 22-33.

Mayeur, C. (I997), 'Discursos y prácticas migratorias: Contradicciones, hipocresías y efectos perversos de las políticas actuales', Migraciones 2: 9-26.

McKeown, A. (2004), 'Global migration, I846-I940', Journal of World History I5 (2): I55-I89.

Mehmet, O. (I988), 'Development in Malaysia: Poverty, wealth and trusteeship', Kuala Lumpur: Insan.

Mezzadra, S. (2005), Derecho de fuga: Migraciones, ciudadanía y globalización. Madrid: Traficantes de Sueños.

Mill, J.S. (I909), Principles of political economy: With some of their applications to social philosophy. London: Longmans.

Miller, M.J. (I986), 'Introduction', International Migration Review 20 (4): 740-760.

Ministerio del Interior (2000, 2002, 2003, 2004, 2005, 2006, 2007, 2008), Anuario Estadístico. www.mir.es/MIR/PublicacionesArchivo/publicaciones/catalogo/ anuariosestadisticos. Accessed 3 November 2009.

Ministerio de Trabajo y Asuntos Sociales (2004, 2005, 2006, 2007, 2008), Anuario. www.mtin.es/estadisticas/anuario2005/welcome.htm. Accessed 3 November 2009.

Ministry of Finance (2005), Economic report 2004/2005. Kuala Lumpur: Malaysia National Printers Berhad.

Ministry of Human Resources (I991), Labour and manpower report 1987-88. Kuala Lumpur.

Ministry of Human Resources (I994), Report on the impact of foreign workers on the Malaysian economy. Kuala Lumpur.

Moch, L.P. (2003), Moving Europeans: Migration in Western Europe since 1650. Indiana: Indiana University Press.

Moha Asri A. \& Morshidi S. (I996), 'Globalized manufacturing activity, local economic development and the demand for labor in Malaysia', paper presented at the international conference Globalization and Development: Lessons for the Malaysian Economy, Kuala Lumpur, I2-3 August 1996.

Mongia, R. (2005), 'Abolition and "free" migration: On historicity and eurocentricity in migration studies', in I. Toshio \& I. Masako (eds.), Motion in Place/Place in Motion, 45-64. JCAS Symposium Series 22. Osaka: The Japan Center for Area Studies.

Moreno Fuentes, F.J. (2005), 'The regularisation of undocumented migrants as a mechanism for the 'emerging' of the Spanish underground economy', CSIC working paper 05-06. Madrid: CSIC.

Moya, J. (I998), Cousing and strangers: Spanish immigrants in Buenos Aires, I850-I930. Berkeley: University of California Press.

Moya Malapeira, D. (2006), 'La evolución del sistema de control migratorio de entrada en España', in E. Aja \& J. Arango (eds.), Veinte años de inmigración en España: Perspectiva jurídica y sociológica (1985-2004), 47-84. Barcelona: CIDOB.

Mullan, B. (I998), 'The regulation of international migration: The US and Western Europe in historical comparative perspective', in A. Böcker et al. (eds.), Regulation of Migration: International Experiences, 27-44. Amsterdam: Het Spinhuis.

Nadal, J. (I975), El fracaso de la revolución industrial en España: I8I4-I9I3. Barcelona: Ariel.

Narayanan, S. \& Y.W. Lai (2005), 'The causes and consequences of immigrant labour in the construction sector in Malaysia', International Migration 43 (5): 3I-57. 
Navamukundan, A. (I988), 'Labour shortage in plantations: A trade union view', Current issues in labour migration in Malaysia. Kuala Lumpur.

Netto, G (1961), Indians in Malaya: Historical facts and figures. Singapore: Netto.

Noiriel, G. (I99I), La tyrannie du nationa: Le droit d'asile en Europe 1793-1993. Paris: Calmann-Levy.

North, D.C. (I990), Institutions, institutional change and economic performance. Cambridge: Cambridge University Press.

Observatorio Permanente de la Inmigración (2006), Anuario estadístico de extranjería 2005. http://extranjeros.mtin.es/es/InformacionEstadistica/Anuarios. Accessed I9 November 2010.

Oliver Alonso, J. (2007), 'Inmigración y mercado de trabajo en 2006: Razones de la acentuación del choque inmigratorio', in E. Aja \& J. Arango (eds.), La inmigración en España en 2006: Anuario de inmigración y políticas de inmigración, 44-67. Barcelona: Edicions Bellaterra.

Oliver Alonso, J. (2005), 'Efecto llamada e inmigración: Razones del choque inmigratorio e impacto en el mercado de trabajo español I995-2005', Índice Laboral Manpower.

Ong, A. (I99I), 'The gender and labor politics of postmodernity', Annual Review of Anthropology 20: 279-309.

Pajares, M. (2007), 'Inmigración y mercado de trabajo. Informe 2007. Análisis de datos de España y Cataluña'. Madrid: Documentos del Observatorio Permanente de la Inmigración.

Palupi, S. \& N. Yasser (2002), 'Laporan investigasi buruh migran Indonesia (TKI) di Nunukan: Korban praktek perbudakan terselubung Indonesia - Malaysia', unpublished report produced by the Jaringan Relawan Kemanusaiaan untuk Nunukan.

Papademetriou, D., P. Martin \& M. Miller (I983), 'US Immigration policy: The guestworker option revisited', International Migration 2I (I): 39-55.

Parmer, J.N. (I960), Colonial labour policy and administration: A history of labour in the rubber plantation industry in Malaya, c. 1980-1941. New York: JJ Austin.

Parreñas, R.S. (200I), Servants of globalization: Women, migration, and domestic work. Stanford: Stanford University Press.

Parreñas, R.S. (2000), 'Migrant Filipina domestic workers and the international division of reproductive labor', Gender \& Society I4 (4): 560-58I.

Penninx, R. \& J. Roosblad (2000), Trade unions, immigration, and immigrants in Europe, 1960-1993. New York/Oxford: Berghahn Books.

Pereira, V. (2007), 'How states can use illegal emigrations: Illegal migrations from Southern Europe to France and Germany, I945-I974', paper presented at SSHA Annual Conference, Chicago, I6 November 2007.

Pérez Rubalcaba, A. (2008), 'Ministerio del Interior e Inmigración', in M. Balado Ruiz-Gallegos (dir.), Inmigración, estado y derecho, 73-79. Barcelona: Editorial Bosch.

Pierson, P. (2004), Politics in time: History, institutions, and social analysis. Princeton: Princeton University Press.

Pillai, P. (2005), Indonesian labour immigrants in Malaysia: A case study of Kampung Sungai Kayu Ara, Selangor, Malaysia, Kuala Lumpur: PhD dissertation. Institut Pengajian Siswazah. Universiti Malaya.

Pillai, P. (2000), 'Labour market developments and international migration in Malaysia', in Organisation for Economic Co-operation and Development (ed.), Migration and the Labour Market in Asia, I37-I49. Paris: OECD. 
Pillai, P. (I999), 'The Malaysian state's response to migration', Sojourn I4 (I): I78-197.

Pillai, P. (1992), People on the move: An overview of recent immigration and emigration in Malaysia. Kuala Lumpur: Institute for Strategic and International Studies.

Piore, M. (I979), Birds of passage: Migrant labour and industrial societies. New York: Cambridge University Press.

Portes, A. (2003), 'Conclusion: Theoretical convergencies and empirical evidence in the study of immigrant transnationalism', International Migration Review 37 (3): $874-892$.

Portes, A. (200I), 'Introduction: The debates and significance of immigrant transnationalism', Global Network I (3): I9I-I93.

Portes, A. (I999), 'Conclusion: Towards a new world: The origins and effects of transnational activities', Ethnic and Racial Studies 22 (2): 463-477.

Portes, A. (I978), 'Illegal Mexican immigrants to the US', International Migration Review I2 (Winter): Special Issue.

Portes, A. (I977), 'Labor functions of illegal aliens', Society I4 (6): 3I-37.

Portes, A. \& R. Bach (I985), Latin journey: Cuban and Mexican immigrants in the United States. Berkeley: University of California Press.

Portes, A. \& J. Walton (198I), Labor, class and the international system. New York: Academic Press.

Prados de la Escosura, L. (I988), De imperio a nación: Crecimiento y atraso económico en España (1780-1930). Madrid: Alianza.

Purcell, M. \& J. Nevins (2005), 'Pushing the boundary: State restructuring, state theory, and the case of U.S-Mexico border enforcement in the I99os', Political Geography 24: 215-235.

Ramachandran, S. (I994), Indian plantation labour in Malaysia. Kuala Lumpur: S. Abdul Majeed for INSAN.

Ramos Gallarín, J. \& I. Bazaga Fernández (2002), 'Gestión intergubernamental y política de inmigración en España: El caso de los procesos de regularización en España', paper presented at VII Congreso Internacional del CLAD Reforma del Estado y de la Administración Pública, Lisbon, 8-II October 2002. www.unpanI. un.org/intradoc/groups/public/.../cladoo444II.pdf. Accessed 3 November 2009.

Rius Sant, X. (2007), El libro de la inmigración en España. Barcelona: Almuzara.

Roig Molés, E. (2007), 'La entrada por razones laborales en Cataluña', in Inmigración y transformación social en Cataluña, 287-334. Bilbao: Fundación BBVA.

Rose, R. (I973), 'Comparing public policy: An overview', European Journal of Political Research I (I): 67-94.

Rudnick, A. (2009), Temporary migration experiences of Bangladeshi women in the Malaysian export industry from a multi-sited perspective. Amsterdam: Amsterdam University Press.

Ruhs, M. \& P. Martin (2006), 'Numbers vs rights: Trade-offs and guest worker programmes', Working paper no. 40. University of Oxford. www.compas.ox.ac. uk/publications/working-papers/wp-o6-40. Accessed 29 August 20II.

Ruppert, E. (I999), 'Managing foreign labour in Singapore and Malaysia', in World Bank Policy Research working paper 2053. http://papers.ssrn.com/sol3/papers. cfm?abstract_id=597250. Accessed 20 November 2009 .

Sadiq, K. (2005), 'When states prefer non-citizens over citizens: Conflict over illegal immigration into Malaysia', International Studies Quarterly 49: IOI-I22.

Sabater, A. \& A. Domingo (20IO), 'Earned legalisation by means of attachment in Spain: A sociodemographic perspective', paper presented at the ESF workshop 
'Migrant legality and employment in contemporary Europe', Institute for Migration and Ethnic Studies, University of Amsterdam, IO-II June 20 IO.

Sagarra i Trías, E. (2002), 'Un nuevo "status” de extranjero en España: El inmigrante, irregular, empadronado, residente trabajando y con orden de expulsión', Derecho de Extranjería I: 89-97.

Salter, M. (2004), 'Passports, mobility and security: How smart can the border be?', International Studies Perspectives 5: 7I-9I.

Sánchez Albornoz, N. (I988), 'Medio siglo de emigración masiva de España hacia América', in N. Sánchez Albornoz (ed.), Españoles hacia America: La emigración en masa, 1880-1930, I3-29. Madrid: Alianza.

Sánchez-Albornoz, N. (I977), España hace un siglo: Una economía dual. Madrid: Alianza.

Sánchez Alonso, B. (I995), Las causas de la emigración española, 1880-1930. Madrid: Alianza.

Sandhu, K.S. (I969), Indians in Malaya: Some aspects of their immigration and settlement. Cambridge: Cambridge University Press.

Sartori, G. (I994), 'Compare why and how: Comparing, miscomparing and the comparative method', in M. Dogan \& A. Kazancigil (eds.), Comparing nations: concepts, strategies, substance, I4-34. Oxford: Blackwell.

Sassen, S. (2002), 'Towards post-national and denationalized citizenship', in E.F. Isin \& B.S. Turner (eds.), Handbook of citizenship studies, 277-293. London: Sage.

Sassen, S. (1996), Losing control? Sovereignty in an age of globalisation. New York: Columbia University Press.

Sassen, S. (I99I), The global city. Oxford: Princeton University Press.

Sassen, S. (I988), The mobility of labor and capital: A study in international investment and labor flow. Cambridge: Cambridge University Press.

Sassen-Koob, S. (1978), 'The international circulation of resources and development: The case of migrant labor', Development and Change 9: 509-545.

Sayad, A. (I994), 'Le mode de génération des générations “immigrées”', L’Homme et la Société III: I54-I74.

Schneider, F. (2004), 'The size of the shadow economies of I45 countries all over the world: First results over the period I999 to 2003', IZA discussion paper no. I43I.

Schrover, M., J. van der Leun, L. Lucassen \& C. Quispel (eds.) (2008), Illegal migration and gender in a global and historical perspective. IMISCOE Research Series. Amsterdam: Amsterdam University Press.

Sciortino, G. (2002), 'Immigration in a Mediterranean welfare state: The Italian case', paper presented at the conference in honor of Tomas Hammar.

Sciortino, G. (2000), 'Toward a political sociology of entry policies: Conceptual problems and theoretical proposals', Journal of Ethnic and Migration Studies 26 (2): $2 \mathrm{I} 3-228$.

Scott, J.C. (I985), Weapons of the weak: Everyday forms of peasant resistance. New Haven: Yale University Press.

Selvaratnam, R. (I980), 'Indian plantation workers in Peninsular Malaysia: Peasants or proletarians', paper presented at the conference Development: The Peasantry and Development in the ASEAN Region, University Kebangsaan Malaysia, Bangi, 26-29 May I980.

Shamsul, A.B. (I998), 'Bureaucratic management of identity in a modern state: Malayness in postwar Malaysia', in D.C. Gladney (ed.), Making majorities: Constituting the nation in Japan, Korea, China, Malaysia, Fiji, Turkey, and the United States, I35-I5O. Stanford: Stanford University Press. 
Shughart, W., R. Tollison \& M. Kimenyi (eds.) (I986), 'The political economy of immigration restrictions', Yale Journal on Regulation 51: 79-97.

Silcock, T.H. (1965), 'The effects of industrialization on race relations in Malaysia', in G. Hunter (ed.), Industrialisation and Race Relations: A Symposium. Oxford: Oxford University Press.

Silveira Gorski, H. (2006), 'La biopolítica ante los flujos migratorios: El regreso de los "campos", paper presented at the V Congreso de las Migraciones en España, Valencia, 7 September 2006.

Silvestre, J. (2007), 'Temporary internal migrations in Spain, I860-I930', Social Science History 3I (4): 539-574.

Solanes, A. (2003a), 'La paradoja del principio de control de flujos migratorios', paper presented in XIX Jornadas de la Sociedad Española de Filosofía Jurídica y Política, Las Palmas de Gran Canaria, 6-7 March 2003.

SOS Racisme (2004), Informe anual. www.sosracisme.org/reflexions/informeanual. php. Accessed 3 November 2009

SOS Racisme (1996), Informe anual. www.sosracisme.org/reflexions/informeanual. php. Accessed 3 November 2009.

Soysal, Y. (I994), Limits of citizenship: Migrants and postnational membership in Europe. Chicago: University of Chicago Press.

Spaan, E., T. van Naerssen \& G. Kohl (2002), 'Re-imagining borders: Malay identity and Indonesian migrants in Malaysia', Tijdschrift voor Economische en Sociale Geografie 93 (2): I60-I72.

Stenson, M.R. (1980), Class, race and colonialism in West Malaysia. Brisbane: University of Queensland Press.

SUARAM (2006), Malaysia, civil and political rights status report 2006.

Suárez Navaz, L. (2000), 'Inmigración irregular, regularizaciones y efectos en la identidad de los inmigrantes', paper presented to the II Congreso de Inmigración, Madrid, 5-7 October 2000.

Suárez-Navaz, L. (I997), 'Political economy of the Mediterranean rebordering: New ethnicities, new citizenships', Standford Electronic Humanities Review 5 (2). http://shr.stanford.edu/shreview/5-2/navaz.html. Accessed 2 April 2003.

Summugam a/l Rengasamy (2006), 'History of plantation labour in (Malaya) Malaysia', The Planter 82 (96I): 26I-272.

Syed Shahir (2006), 'Protection of migrant and refugee rights in Malaysia', paper presented at the conference Challenges of Global Migration and Forced Displacement, Kuala Lumpur, I-2 August 2006.

Tenaganita (2005), Migrant workers: Access denied. Kuala Lumpur: Tenaganita Sdn. Bhd.

Tenaganita (1995), Memorandum on abuse, torture and dehumanised treatment of workers at detention camps. Kuala Lumpur: Tenaganita.

Thielemann, E. (2003), 'Does policy matter? On governments' attempts to control unwanted migration', LSE European Institute working paper 2003-2.

Tokunaga, R. (2005), 'Outsourcing care work: The case of migrant women in Malaysia', unpublished paper.

Torpey, J. (2000), The invention of the passport: Surveillance, citizenship and the state. New York: Cambridge University Press.

Tortella, G. (I994), El desarrollo de la España contemporánea: Historia económica de los siglos XIX Y XX. Madrid: Alianza.

Tortella, G. (I987), 'Agriculture: A slow-moving sector, I830-I935', in N. Sánchez- 
Albornoz (ed.), The Economic modernization of Spain, 1980-1930, 43-62. New York: New York University Press.

Tyrrell, I. (I99I), 'American exceptionalism in an age of international history', American Historical Review 96: I03I-I056.

UN Human Development Report 2007/2008. www.undp.org/en/reports/global/ hdr2007-2008. Accessed 24 August 2009.

Van Amersfoort, H. (200I), 'Will the welfare state survive globalisation? International migration and the loss of territorial control', in G. Dijkink \& $\mathrm{H}$. Knippenberg (eds.), The territorial factor: Political geography in a globalizing world, I53-I76. Amsterdam: Vossiuspers UvA.

Van Amersfoort, H. (2008), 'Citizenship, ethnicity and mainstream society: The European welfare states navigating between exclusion and inclusion', paper presented at the Cronem Annual Conferece, University of Surrey (UK), 30 June- I July 2008.

Van der Leun, J. (2003), Looking for loopholes: Processes of incorporation of illegal immigrants in the Netherlands. Amsterdam: Amsterdam University Press.

Van Schendel, W. \& I. Abraham (2005), Illicit flows and criminal things: States, borders, and the other side of globalization. Bloomington: Indiana University Press.

Varsanyi, M. (2006), 'Interrogating “urban citizenship” vis-à-vis undocumented migration', Citizenship Studies Io (2): 229-249.

Venturini, A. (2004) Postwar migration in Southern Europe, 1950-2000: An economic analysis. Cambridge: Cambridge University Press.

Vernant, J. (1953), The refugee in the Post War World. London: Allen \& Unwin.

Vincenti, E. (I908), Estudio sobre emigración: Guías especiales del emigrante español en América Y Argelia. Madrid: Imp. de los H. de M.G. Hernández.

Walters, W. (2006), 'Border/control', European Journal of Social Theory 9 (2): I87-203.

Walzer, M. (1983), Spheres of justice. New York: Basic Books.

Wang, G. (I992), 'Migration patterns in history: Malaysia and the region', in G. Wang, (ed.), Community and nation: China, Southeast Asia and Australia. Kensington: Allen and Unwin.

Watts, J.R. (I999), 'Italian and Spanish labour leaders' unconventional immigration policy preferences', in M. Baldwin-Edwards \& J. Arango (eds.), Immigrants and the informal economy in Southern Europe, I29-I48. London: Frank Cass.

Watts, J.R. (I998), 'Strange bedfellows: How Spanish labor union leaders and employers find common ground on immigration', Policy Studies Journal 26 (4): 657-675.

Wong, D. (2006), 'The recruitment of foreign labour in Malaysia: From migration system to guest worker regime', in A. Kaur \& I. Metcalfe (eds.), Mobility, labour migration and border controls in Asia, 213-227. Hampshire: Palgrave Macmillan.

Wong, D. (2005), 'The rumor of trafficking: Border controls, illegal migration and the sovereignity of the nation-state', in W. Van Schendel \& I. Abraham (eds.), Illicit flows and criminal things: States, borders and the other side of globalization, II9-I3I. Bloomington: University of Indiana Press.

Wong, D. (2002), 'The national context of migration research in Malaysia: Which nation, what state, whose migration?', Osnabruck.

Wong, D. \& T. Afrizal Teuku Anwar (2003), 'Migran Gelap: Indonesian migrants in Malaysia's irregular labour economy', in G. Battistella \& M.B. Asis (eds.), Unauthorised migration in Southeast Asia, I69-227. Manila: Scalabrini Migration Centre. 
Woolard, K.A. (1986), "The "crisis in the concept of identity" in contemporary Catalonia, I976-I982', in G. McDonough (ed.), Conflict in Catalonia: Images of an urban society, 54-7I. Gainesville: University of Florida Press.

World Bank (I995), Malaysia: Meeting labor needs, more workers and better skills. Washington, D.C.

Yin, R.K. (I994), Case study research: Design and methods. 2nd ed. London: Sage.

Zapata-Barrero, R. (I997), 'Ética y política de inmigración', Revista de Treball Social I46: 68-87.

Zapata-Barrero, R. \& N. De Witte (2007), 'The Spanish governance of EU borders: Normative questions', Mediterranean Politics I2 (I): 85-90.

Zapata-Barrero, R., R. Faúndez García \& E. Sánchez Montijano (2009), 'Temporary and circular labour migration: Reassessing established public policies', GRITIM working paper I. http://recercat.test.cesca.es/handle/2072/4I897. Accessed 29 August 20II.

Zolberg, A. (1999), 'Matters of state: Theorizing immigration policy', in C. Hirschman, P. Kasinitz \& J. De Wind (eds.), The handbook of international migration, 7I-79. New York: Russell Sage Foundation.

Zolberg, A. (1989), 'The next waves: Migration theory for a changing world', International Migration Review 23 (3): 403-4 


\section{Annex 1: Maps of Malaysia and Spain}

Map 1 Malaysia and its main countries of immigration

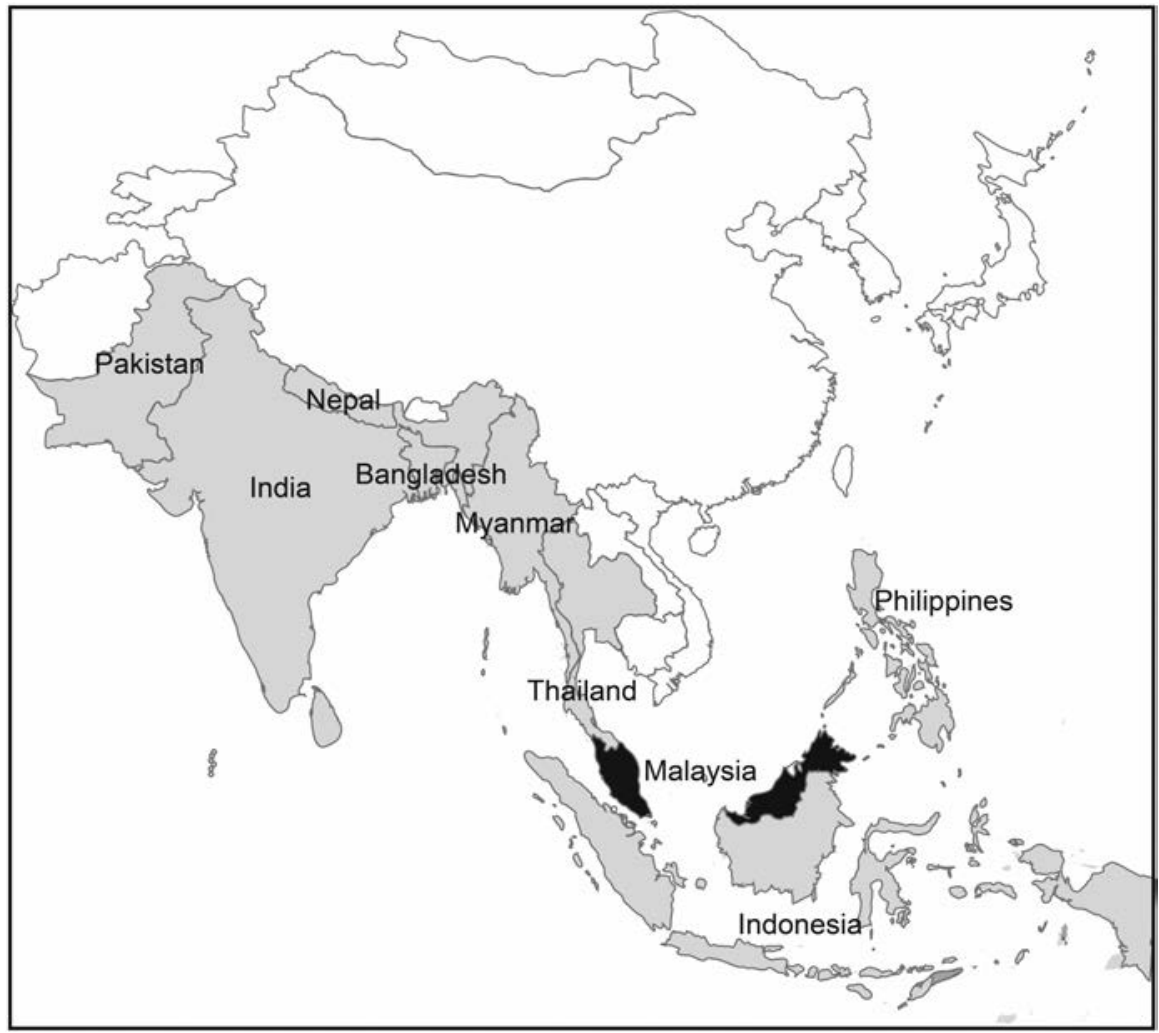

Source: Author 
Map 2 Spain and its main countries of immigration

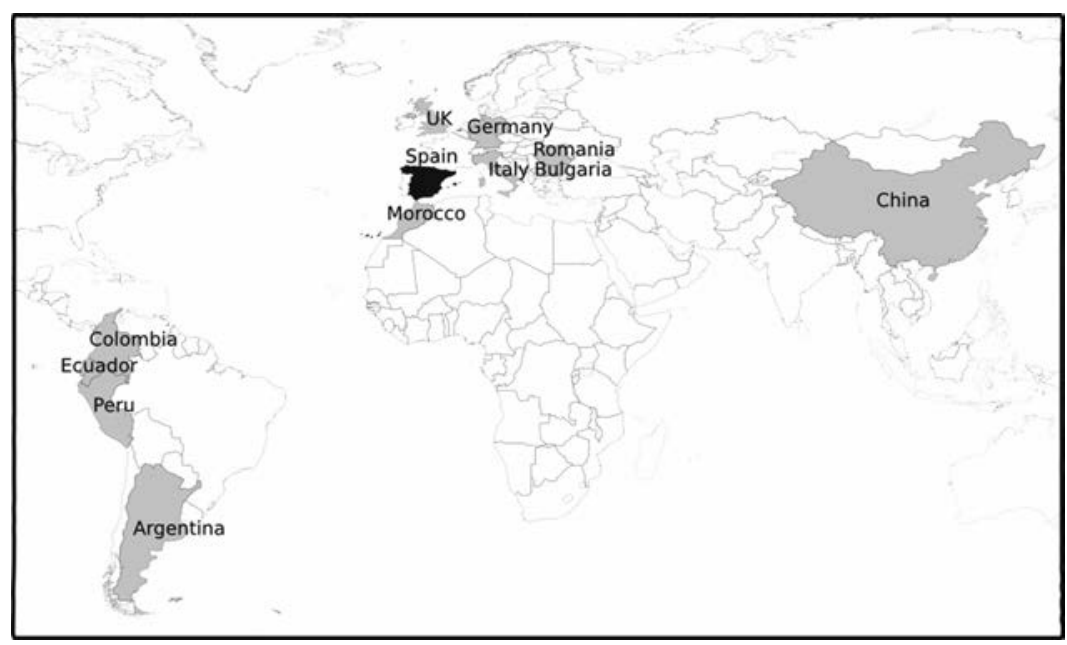

Source: Author 


\section{Annex 2: Acronyms}

In Malaysia

CIDB: Construction Industry Development Board Malaysia

CLAB: Construction Labour Exchange Centre Berhad

DAP: Democratic Action Party (Chinese opposition party)

FMM: Federation of Malaysian Manufacturers

PAPA: Malaysian Association of Foreign Maid Agencies

MAPA: Malaysian Agricultural Producers' Association

MBAM: Master Builders Association Malaysia

MCA: Malayan Chinese Association

MEF: Malaysian Employers Federation

MIC: $\quad$ Malayan Indian Congress

MPOA: Malaysian Palm Oil Association

MTUC: Malaysian Trade Union Congress

NEP: $\quad$ New Economic Policy

NUPW: National Union of Plantation Workers

UMNO: United Malays National Organisation

In Spain

ASTI: Asociación para la Solidaridad con los Trabajadores Inmigrantes (Association for Solidarity with Immigrant Workers)

ATIME: Asociación de Trabajadores Inmigrantes Marroquíes (Association of Moroccan Immigrant Workers)

CEAR: Comisión Española de Ayuda al Refugiado (Spanish Commission for Refugee Aid)

CES: Consejo Económico y Social (Social and Economic Council)

CCOO: Comisiones Obreras (Workers' Commissions)

EEC: European Economic Community

LOE: Ley Orgánica de Extranjería (Organic Law on Foreigners)

PSOE: Partido Socialista Obrero Español (Socialist Party)

PP: $\quad$ Partido Popular (Popular Party)

UGT: Unión General de Trabajadores (General Workers Union) 


\section{Annex 3: Migration policies}

In Malaysia (1980-2006)

\begin{tabular}{|c|c|c|c|}
\hline Date & Policy & Content & Result \\
\hline 1984 & $\begin{array}{l}\text { Agreement with } \\
\text { Indonesia }\end{array}$ & $\begin{array}{l}\text { To recruit workers for } \\
\text { plantations }\end{array}$ & \multirow{3}{*}{$\begin{array}{l}\text { From } 1985 \text { to } 1989 \text {, a } \\
\text { total of } 31,420 \text { work } \\
\text { permits issued against } \\
\text { an estimated } 550,000 \\
\text { foreign workers } \\
\text { employed in the labour } \\
\text { market }\end{array}$} \\
\hline 1985 & $\begin{array}{l}\text { Agreement with } \\
\text { the Philippines }\end{array}$ & $\begin{array}{l}\text { To recruit workers for } \\
\text { domestic services }\end{array}$ & \\
\hline 1986 & $\begin{array}{l}\text { Agreement with } \\
\text { Bangladesh and } \\
\text { Thailand }\end{array}$ & $\begin{array}{l}\text { To recruit workers for } \\
\text { plantations }\end{array}$ & \\
\hline 1989 & $\begin{array}{l}\text { 1st regularisation } \\
\text { programme }\end{array}$ & $\begin{array}{l}\text { Regularisation of illegal } \\
\text { workers in plantations }\end{array}$ & $\begin{array}{l}20,000 \text { foreign workers } \\
\text { regularised, although } \\
\text { estimated number of } \\
\text { illegal migrants was } \\
\text { much higher }\end{array}$ \\
\hline 1991 & $\begin{array}{l}\text { Comprehensive } \\
\text { Policy on the } \\
\text { Recruitment of } \\
\text { Foreign Workers }\end{array}$ & $\begin{array}{l}\text { Policy regulating recruitment, } \\
\text { entrance and stay of foreign } \\
\text { workers }\end{array}$ & $\begin{array}{l}769,566 \text { work permits } \\
\text { issued up until } 2002\end{array}$ \\
\hline 1992 & $\begin{array}{l}\text { Imposition of } \\
\text { annual levy }\end{array}$ & $\begin{array}{l}\text { Levy imposed by sector and } \\
\text { skill to raise employment cost } \\
\text { of foreign workers and } \\
\text { therefore discourage } \\
\text { employers from being over- } \\
\text { dependent on migrant } \\
\text { workers }\end{array}$ & $\begin{array}{l}\text { Levy deducted from } \\
\text { foreign workers' wages } \\
\text { and increases costs of } \\
\text { legality }\end{array}$ \\
\hline 1992 & $\begin{array}{l}\text { 2nd regularisation } \\
\text { programme }\end{array}$ & $\begin{array}{l}\text { Regularisation of illegal } \\
\text { workers in domestic services, } \\
\text { construction, plantations, } \\
\text { manufacturing and service }\end{array}$ & $\begin{array}{l}442,276 \text { workers } \\
\text { registered but only } 20 \% \\
\text { ultimately applied for } \\
\text { work permits }\end{array}$ \\
\hline
\end{tabular}




\begin{tabular}{|c|c|c|c|}
\hline Date & Policy & Content & Result \\
\hline 1992 & $\begin{array}{l}\text { Amendments of } \\
\text { the Private } \\
\text { Employment } \\
\text { Agencies Act } 1981\end{array}$ & $\begin{array}{l}\text { Introduced requirement to } \\
\text { use private agents for } \\
\text { recruitment of foreign labour }\end{array}$ & $\begin{array}{l}\text { Recruitment agencies } \\
\text { officially recognised }\end{array}$ \\
\hline $1993-1994$ & $\begin{array}{l}\text { Several bans on } \\
\text { new recruitment }\end{array}$ & $\begin{array}{l}\text { Introduced to promote } \\
\text { recruitment of illegal } \\
\text { migrants from detention } \\
\text { camps }\end{array}$ & $\begin{array}{l}\text { Repeatedly lifted } \\
\text { following employers' } \\
\text { demands }\end{array}$ \\
\hline 1995 & Task force & $\begin{array}{l}\text { Took over all foreign worker } \\
\text { recruitment, except for } \\
\text { domestic workers and store } \\
\text { salespeople }\end{array}$ & $\begin{array}{l}\text { Agents become } \\
\text { 'consultants' to handle } \\
\text { paperwork for employers }\end{array}$ \\
\hline 1996 & $\begin{array}{l}\text { 3rd regularisation } \\
\text { programme }\end{array}$ & $\begin{array}{l}\text { Regularisation of illegal } \\
\text { workers in plantations, } \\
\text { manufacturing, construction } \\
\text { and service }\end{array}$ & $\begin{array}{l}423,180 \text { workers } \\
\text { registered but many did } \\
\text { not get work permits }\end{array}$ \\
\hline $\begin{array}{l}\text { February } \\
1997\end{array}$ & $\begin{array}{l}\text { Amendments of } \\
\text { the Immigration } \\
\text { Act }\end{array}$ & $\begin{array}{l}\text { Introduced heavier fines for } \\
\text { illegal migrants, employers } \\
\text { and agents }\end{array}$ & $\begin{array}{l}\text { Penalisation of illegal } \\
\text { migrants (much more } \\
\text { severe than employers } \\
\text { and agents) }\end{array}$ \\
\hline $\begin{array}{l}\text { March } \\
1997\end{array}$ & $\begin{array}{l}\text { Task force } \\
\text { disbanded due to } \\
\text { ineffectiveness }\end{array}$ & $\begin{array}{l}\text { Functions taken over by } \\
\text { Foreign Workers Division of } \\
\text { the Immigration Department }\end{array}$ & $\begin{array}{l}\text { Speedier and less } \\
\text { cumbersome processing } \\
\text { of work permits }\end{array}$ \\
\hline $\begin{array}{l}\text { August } \\
1997\end{array}$ & \multicolumn{2}{|c|}{ Ban on new recruitments following financial crisis } & $\begin{array}{l}\text { Reduction in number of } \\
\text { work permits issued }\end{array}$ \\
\hline $\begin{array}{l}\text { September } \\
1997\end{array}$ & \multicolumn{3}{|c|}{$\begin{array}{l}\text { Ban lifted on domestic workers and foreign workers in island hotel resorts } \\
\text { following protests from employers }\end{array}$} \\
\hline $\begin{array}{l}\text { January } \\
1998\end{array}$ & $\begin{array}{l}\text { Ban on renewal of } \\
\text { work permits }\end{array}$ & $\begin{array}{l}\text { Ban imposed on foreign } \\
\text { workers in manufacturing, } \\
\text { construction and service } \\
\text { sectors }\end{array}$ & $\begin{array}{l}\text { Policy of redeployment } \\
\text { of workers to plantations } \\
\text { and repatriation of many } \\
\text { 're-categorised' migrants }\end{array}$ \\
\hline 1998 & $\begin{array}{l}\text { Increased annual } \\
\text { levy }\end{array}$ & $\begin{array}{l}\text { Levies on foreign workers in } \\
\text { service, construction and } \\
\text { manufacturing increased; } \\
\text { though remained the same in } \\
\text { domestic service and } \\
\text { plantations }\end{array}$ & $\begin{array}{l}\text { Increased costs of } \\
\text { legality }\end{array}$ \\
\hline
\end{tabular}

July 1998 Ban lifted on renewal of work permits for the service sector following protests from employers 


\begin{tabular}{|c|c|c|c|}
\hline Date & Policy & Content & Result \\
\hline $\begin{array}{l}\text { October } \\
1998\end{array}$ & $\begin{array}{l}\text { Ban lifted on new } \\
\text { from employers }\end{array}$ & recruitments following protests & $\begin{array}{l}120,000 \text { new work } \\
\text { permits approved in } \\
\text { plantations and } \\
\text { construction sector }\end{array}$ \\
\hline 1999 & $\begin{array}{l}\text { Reduction in } \\
\text { annual levy }\end{array}$ & \multicolumn{2}{|c|}{$\begin{array}{l}\text { To facilitate employment of foreign workers and hence } \\
\text { promote economic recovery }\end{array}$} \\
\hline 2001 & $\begin{array}{l}\text { New limit of } \\
\text { temporary work } \\
\text { pass }\end{array}$ & $\begin{array}{l}\text { Work pass reduced from } 5 \text { to } 3 \\
\text { years due to economic } \\
\text { slowdown following increase } \\
\text { in unemployment rate }\end{array}$ & $\begin{array}{l}\text { Many legal migrants } \\
\text { suddenly become illegal }\end{array}$ \\
\hline 2002 & $\begin{array}{l}\text { 'Hire } \\
\text { Indonesians Last' }\end{array}$ & $\begin{array}{l}\text { To reduce Indonesian share in } \\
\text { labour market following riots } \\
\text { of Indonesian workers in work } \\
\text { places and detention camps }\end{array}$ & $\begin{array}{l}\text { Policy rescinded after two } \\
\text { weeks as the structural } \\
\text { position of Indonesian } \\
\text { workers in the Malaysian } \\
\text { economy gets recognised }\end{array}$ \\
\hline 2002 & $\begin{array}{l}\text { Amnesty for } \\
\text { voluntary return }\end{array}$ & $\begin{array}{l}\text { Illegal migrants 'invited' to } \\
\text { leave Malaysia without } \\
\text { penalties }\end{array}$ & $\begin{array}{l}570,000 \text { (mostly } \\
\text { Indonesian) immigrants } \\
\text { accept amnesty, thus } \\
\text { producing huge labour } \\
\text { shortages }\end{array}$ \\
\hline 2002 & $\begin{array}{l}\text { Amendments } \\
\text { Immigration Act }\end{array}$ & $\begin{array}{l}\text { Illegal entry is sanctioned with } \\
\text { maximum fine of RM 10,000 } \\
\text { or jail term not exceeding } 5 \\
\text { years and a mandatory caning; } \\
\text { those found guilty of } \\
\text { harbouring or employing } \\
\text { illegal migrants are fined RM } \\
10,000-\mathrm{RM} 50,000 \text { per } \\
\text { employee and a jail term not } \\
\text { exceeding one year }\end{array}$ & $\begin{array}{l}\text { Increased penalisation of } \\
\text { illegal migrants; } \\
\text { employers and agents } \\
\text { also penalised }\end{array}$ \\
\hline $2004-2005$ & $\begin{array}{l}\text { Amnesty for } \\
\text { voluntary return }\end{array}$ & $\begin{array}{l}\text { Illegal migrants invited to } \\
\text { leave Malaysia without } \\
\text { penalties; subsequently invited } \\
\text { to come back to Malaysia } \\
\text { legally }\end{array}$ & $\begin{array}{l}\text { About } 500,000 \text { migrants } \\
\text { leave the country; only a } \\
\text { few return to Malaysia }\end{array}$ \\
\hline 2006 & $\begin{array}{l}\text { Legal recognition } \\
\text { of outsourcing } \\
\text { companies }\end{array}$ & $\begin{array}{l}\text { Agencies recognised not only } \\
\text { as recruiters, but also as legal } \\
\text { employers to outsource their } \\
\text { labour to 'real' employers }\end{array}$ & $\begin{array}{l}\text { Recruitment and em- } \\
\text { ployment of foreign wor- } \\
\text { kers in Malaysia facil- } \\
\text { itated; also gives many } \\
\text { opportunities for employ- } \\
\text { ers to escape legal obli- } \\
\text { gations and payment }\end{array}$ \\
\hline
\end{tabular}


In Spain (1980-2007)

\begin{tabular}{|c|c|c|c|}
\hline Date & Policy & Content & Result \\
\hline 1985 & $\begin{array}{l}\text { Ley Orgánica de } \\
\text { Extranjería (LOE) }\end{array}$ & $\begin{array}{l}\text { Introduction of the requirements } \\
\text { for residence and work permits; } \\
\text { exclusion and criminalisation of } \\
\text { illegality }\end{array}$ & $\begin{array}{l}\text { Followed by several } \\
\text { constitutional } \\
\text { sentences and } \\
\text { modifications of the } \\
\text { law as a result of } \\
\text { pressure from } \\
\text { immigrants' } \\
\text { organisations, NCOs } \\
\text { and opposition parties }\end{array}$ \\
\hline 1985 & 1st regularisation & $\begin{array}{l}\text { Process of 'documentation' of } \\
\text { immigrants already in the country }\end{array}$ & $\begin{array}{l}43,814 \text { applications } \\
(38,181 \text { authorised); } \\
\text { only } 58 \% \text { of those } \\
\text { regularised still in a } \\
\text { legal situation in } 1990\end{array}$ \\
\hline 1986 & $\begin{array}{l}\text { Entry to the } \\
\text { European } \\
\text { Economic } \\
\text { Community }\end{array}$ & $\begin{array}{l}\text { Freedom of circulation and free } \\
\text { access to the labour market for } \\
\text { EEC citizens }\end{array}$ & $\begin{array}{l}\text { New category } \\
\text { emerged for privileged } \\
\text { foreigners: } \\
\text { community citizens }\end{array}$ \\
\hline 1991 & $\begin{array}{l}\text { Proposición no de } \\
\text { Ley (Green Paper) }\end{array}$ & $\begin{array}{l}\text { First formulation of an integrated } \\
\text { immigration policy }\end{array}$ & $\begin{array}{l}\text { Towards a } \\
\text { comprehensive } \\
\text { immigration policy }\end{array}$ \\
\hline 1991 & 2nd regularisation & Regularisation of migrant workers & $\begin{array}{l}135,393 \text { applications } \\
(116,469 \text { authorised); } \\
28,000 \text { do not renew } \\
\text { the permit }\end{array}$ \\
\hline 1993 & $\begin{array}{l}\text { Establishment of } \\
\text { the quota system }\end{array}$ & $\begin{array}{l}\text { Annual labour immigration } \\
\text { ceiling; needs of the labour } \\
\text { market are determined prior to } \\
\text { the offer of employment }\end{array}$ & $\begin{array}{l}\text { Quota system used as } \\
\text { a mechanism for } \\
\text { regularisation of those } \\
\text { migrants workers } \\
\text { already in Spain }\end{array}$ \\
\hline 1991 & \multicolumn{2}{|c|}{$\begin{array}{l}\text { Introduction of visa requirements for citizens from } \\
\text { Maghreb and Peru }\end{array}$} & $\begin{array}{l}\text { Increased border } \\
\text { closure }\end{array}$ \\
\hline 1993 & \multicolumn{2}{|c|}{$\begin{array}{l}\text { Introduction of visa requirements for citizens from } \\
\text { Dominican Republic }\end{array}$} & $\begin{array}{l}\text { Increased border } \\
\text { closure }\end{array}$ \\
\hline 1993 & \multicolumn{2}{|c|}{$\begin{array}{l}\text { Ratification of the application of the Schengen } \\
\text { Agreement }\end{array}$} & $\begin{array}{l}\text { Transformed EU } \\
\text { internal borders and } \\
\text { expanded } \\
\text { infrastructure at } \\
\text { external borders }\end{array}$ \\
\hline
\end{tabular}




\begin{tabular}{|c|c|c|c|}
\hline Date & Policy & Content & Result \\
\hline 1996 & $\begin{array}{l}\text { New Law on } \\
\text { Foreigners } \\
\text { Regulations }\end{array}$ & $\begin{array}{l}\text { First permanent residence } \\
\text { permit, regulation of family } \\
\text { reunification }\end{array}$ & $\begin{array}{l}\text { Less restrictive policy } \\
\text { for the regulation of } \\
\text { migrants' stay; } \\
\text { recognised } \\
\text { permanence of } \\
\text { migrants in Spain }\end{array}$ \\
\hline 1996 & 3 rd regularisation & $\begin{array}{l}\text { Regularisation of migrants who } \\
\text { did get a permit but had returned } \\
\text { to a status of illegality }\end{array}$ & $\begin{array}{l}24,691 \text { applications } \\
\text { (22,000 accepted) }\end{array}$ \\
\hline 2000 & $\begin{array}{l}\text { Ley Orgánica (LO) } \\
\text { 4/2000 }\end{array}$ & $\begin{array}{l}\text { More rights for legal migrants; } \\
\text { access to health care and } \\
\text { education for illegal migrants; } \\
\text { introduction of individual } \\
\text { regularisation programme; illegal } \\
\text { residence sanctioned with a fine } \\
\text { instead of expulsion }\end{array}$ & $\begin{array}{l}\text { Law modified just few } \\
\text { months after it was } \\
\text { passed }\end{array}$ \\
\hline 2000 & LO $8 / 2000$ & $\begin{array}{l}\text { Limits imposed on permanent } \\
\text { residence, representation at } \\
\text { municipal level and right to } \\
\text { family reunification; expulsion } \\
\text { reinstated for illegality of } \\
\text { residence or work }\end{array}$ & $\begin{array}{l}\text { Approach to } \\
\text { immigration became } \\
\text { more restrictive } \\
\text { though maintained } \\
\text { important rights for } \\
\text { legal and illegal } \\
\text { migrants, e.g. access } \\
\text { to health care and } \\
\text { education for } \\
\text { migrants who are } \\
\text { registered (in El } \\
\text { padrón, municipal } \\
\text { census) albeit illegal }\end{array}$ \\
\hline 2000 & 4th regularisation & $\begin{array}{l}\text { Regularisation programme } \\
\text { following legislative change (LO } \\
4 / 200 \text { ) }\end{array}$ & $\begin{array}{l}246,086 \text { applications } \\
(146,781 \text { authorised) }\end{array}$ \\
\hline 2000 & $\begin{array}{l}\text { Closure of the } \\
\text { Régimen General; } \\
\text { entry only through } \\
\text { the quota system }\end{array}$ & $\begin{array}{l}\text { Agreements with Morocco (1991, } \\
2001) \text {, Colombia and Ecuador } \\
(2001) \text {, Romania (2002), } \\
\text { Dominican Republic (2002), } \\
\text { Poland (2002), Bulgaria (2003) to } \\
\text { make administration of the } \\
\text { countries of origin ultimately } \\
\text { responsible for candidate } \\
\text { selection }\end{array}$ & $\begin{array}{l}\text { Very restrictive entry } \\
\text { policy. Legal } \\
\text { production of illegal } \\
\text { migration }\end{array}$ \\
\hline
\end{tabular}




\begin{tabular}{|c|c|c|c|}
\hline Date & Policy & tent & Result \\
\hline 2001 & $\begin{array}{l}\text { Post-4th } \\
\text { regularisation }\end{array}$ & $\begin{array}{l}\text { sion of applications rejected } \\
\text { rmer process, regularisation } \\
\text { cuadorian citizens and } \\
\text { nsion of regularisation } \\
\text { cedures to other illegal } \\
\text { rants }\end{array}$ & $\begin{array}{l}351,269 \text { applications } \\
(223,428 \text { authorised })\end{array}$ \\
\hline 2001 & $\begin{array}{l}\text { Introduction of visa requ } \\
\text { Cuba and Peru }\end{array}$ & ements for citizens from & $\begin{array}{l}\text { Increased border } \\
\text { closure }\end{array}$ \\
\hline 2002 & $\begin{array}{l}\text { Introduction of visa requ } \\
\text { Colombia }\end{array}$ & ements for citizens from & $\begin{array}{l}\text { Increased border } \\
\text { closure }\end{array}$ \\
\hline 2003 & $\begin{array}{l}\text { Introduction of visa requ } \\
\text { Ecuador }\end{array}$ & ements for citizens from & $\begin{array}{l}\text { Increased border } \\
\text { closure }\end{array}$ \\
\hline 2004 & $\begin{array}{l}\text { New Law on Foreigners } \\
\text { Regulations }\end{array}$ & $\begin{array}{l}\text { The Régimen General is } \\
\text { reopened with the so-called } \\
\text { catalogue of hard-to-fill jobs; } \\
\text { reintroduction of individual } \\
\text { regularisation procedures } \\
\text { (arraigo social y laboral, } \\
\text { social and labour stability) }\end{array}$ & $\begin{array}{l}\text { Entry policy became } \\
\text { more open; ongoing } \\
\text { individual } \\
\text { regularisation process }\end{array}$ \\
\hline 2005 & $5^{\text {th }}$ regularisation & $\begin{array}{l}\text { Regularisation of migrant } \\
\text { workers to reduce 'informal } \\
\text { economy' (regularisation of } \\
\text { employers) }\end{array}$ & $\begin{array}{l}691,655 \text { applications } \\
(83.6 \% \text { granted, thus } \\
578,375 \text { authorised) }\end{array}$ \\
\hline 2006 & Plan Africa & $\begin{array}{l}\text { Concrete measures on } \\
\text { migration control in } \\
\text { countries of origin and } \\
\text { transit and on repatriation } \\
\text { of illegal migrants; bilateral } \\
\text { agreements with Senegal, } \\
\text { Mali, Ghana, Cameroon, } \\
\text { Ivory Coast, Cape Verde, } \\
\text { Guinea-Conakry and } \\
\text { Gambia }\end{array}$ & $\begin{array}{l}\text { Agreements with } \\
\text { countries of origin or } \\
\text { transit serving more } \\
\text { as agreements on } \\
\text { border monitoring } \\
\text { and control than as } \\
\text { readmission } \\
\text { agreements }\end{array}$ \\
\hline 2007 & \multicolumn{2}{|c|}{$\begin{array}{l}\text { Introduction of visa requirements for citizens from } \\
\text { Bolivia }\end{array}$} & $\begin{array}{l}\text { Increased border } \\
\text { closure }\end{array}$ \\
\hline
\end{tabular}




\section{Annex 4: List of interviews}

In Malaysia

\begin{tabular}{|c|c|c|}
\hline No. & Date & Institution/function \\
\hline 1 & $13 / 09 / 2006$ & Malaysian Employers Federation \\
\hline 2 & $14 / 09 / 2006$ & Malaysian Agricultural Producers' Association (MAPA) \\
\hline 3 & $15 / 09 / 2006$ & Federation of Malaysian Manufacturers \\
\hline 4 & $16 / 09 / 2006$ & Domestic workers agency \\
\hline 5 & $18 / 09 / 2006$ & Employer of an electronic industrial company \\
\hline 6 & $18 / 09 / 2006$ & Outsourcing company \\
\hline 7 & $20 / 09 / 2006$ & Small and Medium Industries Development Corporation \\
\hline 8 & $21 / 09 / 2006$ & Malaysian Palm Oil Association \\
\hline 9 & $22 / 09 / 2006$ & Master Builders Association Malaysia \\
\hline 10 & $26 / 09 / 2006$ & Malaysian Association of Foreign Maid Agencies \\
\hline 11 & $26 / 09 / 2006$ & Indonesian embassy in Kuala Lumpur \\
\hline 12 & $28 / 09 / 2006$ & Labour Department - Ministry of Human Resources \\
\hline 13 & $29 / 09 / 2006$ & Outsourcing company \\
\hline 14 & $29 / 09 / 2006$ & $\begin{array}{l}\text { Malaysian Administrative Modernisation and Management } \\
\text { Planning Unit (MAMPU) }\end{array}$ \\
\hline 15 & $02 / 10 / 2006$ & Researcher on immigration \\
\hline 16 & $04 / 10 / 2006$ & Tenaganita \\
\hline 17 & $06 / 10 / 2006$ & Immigration Department \\
\hline 18 & $06 / 10 / 2006$ & $\begin{array}{l}\text { Malaysian Administrative Modernisation and Management } \\
\text { Planning Unit (MAMPU) (2nd interview) }\end{array}$ \\
\hline 19 & $09 / 10 / 2006$ & National Union of Plantation Workers \\
\hline 20 & $10 / 10 / 2006$ & Construction Industry Development Board Malaysia \\
\hline 21 & $10 / 10 / 2006$ & Malaysian Trade Union Congress \\
\hline 22 & $11 / 10 / 2006$ & Labour and immigration lawyer \\
\hline
\end{tabular}




\begin{tabular}{lll}
\hline No. & Date & Institution/function \\
\hline 23 & $12 / 10 / 2006$ & Construction Labour Exchange Centre Berhad \\
24 & $13 / 10 / 2006$ & Malaysian Association of Foreign Maid Agencies (2) \\
25 & $16 / 19 / 2006$ & Amnesty International \\
26 & $17 / 10 / 2006$ & Tenaganita (2) \\
27 & $16 / 10 / 2006$ & Filipino embassy in Kuala Lumpur \\
28 & $20 / 10 / 2006$ & Cabinet Committee on Foreign Workers \\
29 & $09 / 01 / 2008$ & Tenaganita (3) \\
30 & $09 / 01 / 2008$ & Immigration lawyer \\
31 & $11 / 01 / 2008$ & Migrant Care \\
32 & $14 / 01 / 2008$ & Democratic Action Party \\
33 & $14 / 01 / 2008$ & Indonesian embassy in Kuala Lumpur (2) \\
34 & $16 / 01 / 2008$ & Tenaganita (4) \\
35 & $17 / 01 / 2008$ & Journalist at The Star \\
36 & $20 / 01 / 2008$ & Tenaganita (5) \\
\hline
\end{tabular}




\begin{tabular}{|c|c|c|}
\hline No. & Date & Institution/function \\
\hline 1 & $03 / 10 / 2007$ & Employers' organisation CECOT (Barcelona) \\
\hline 2 & $08 / 10 / 2007$ & NGO Bayt Al-Thaqafa (Barcelona) \\
\hline 3 & $31 / 10 / 2007$ & Employers' organisation: Foment del Treball (Barcelona) \\
\hline 4 & $31 / 10 / 2007$ & Immigration lawyer (Barcelona) \\
\hline 5 & $06 / 11 / 2007$ & Employers' organisation: PIMEC (Barcelona) \\
\hline 6 & $12 / 12 / 2007$ & Servei d'Ocupació de Catalunya (Barcelona) \\
\hline 7 & $12 / 12 / 2007$ & NGO Bayt-Al-Thagafa (2) (Barcelona) \\
\hline 8 & $17 / 12 / 2007$ & NGO APIP (Barcelona) \\
\hline 9 & $18 / 12 / 2007$ & Immigration lawyer (Barcelona) \\
\hline 10 & $05 / 02 / 2008$ & Researcher on immigration (Madrid) \\
\hline 11 & $05 / 02 / 2008$ & Rumiñahui (Madrid) \\
\hline 12 & $06 / 02 / 2008$ & CCOO (Madrid) \\
\hline 13 & $06 / 02 / 2008$ & ATIME (Madrid) \\
\hline 14 & $07 / 02 / 2008$ & CEOE (Madrid) \\
\hline 15 & $07 / 02 / 2008$ & Recode (Madrid) \\
\hline 16 & $08 / 02 / 2008$ & Ministerio del Interior (Madrid) \\
\hline 17 & $11 / 02 / 2008$ & CCOO (Barcelona) \\
\hline 18 & $12 / 02 / 2008$ & UGT (Barcelona) \\
\hline 19 & $14 / 02 / 2008$ & Researcher on immigration (Barcelona) \\
\hline 20 & $16 / 02 / 2008$ & Migrants' organisation ATIMCA (Barcelona) \\
\hline 21 & $11 / 03 / 2008$ & $\begin{array}{l}\text { Former Secretary of Immigration of the Catalan Government } \\
\text { (Barcelona) }\end{array}$ \\
\hline 22 & $12 / 03 / 2008$ & Employer in agriculture (Barcelona) \\
\hline 23 & $17 / 03 / 2008$ & Immigration lawyer (Barcelona) \\
\hline
\end{tabular}




\begin{tabular}{lll}
\hline No. & Date & Institution/function \\
\hline 24 & $20 / 03 / 2008$ & Employers' organisation Gremi d'Hostaleria (Barcelona) \\
25 & $25 / 03 / 2008$ & Employer in construction (Barcelona) \\
26 & $08 / 04 / 2008$ & Collegi d'Advocats (Barcelona) \\
27 & $11 / 04 / 2008$ & NGO Caritas (Barcelona) \\
28 & $14 / 04 / 2008$ & CITE, CCOO (Barcelona) \\
29 & $16 / 04 / 2008$ & Researcher (Barcelona) \\
30 & $21 / 04 / 2008$ & Subdelegació de Govern (Barcelona) \\
31 & $09 / 05 / 2008$ & Federación Española de Hostelería (Madrid) \\
32 & $12 / 05 / 2008$ & Confederación Nacional de la Construcción (Madrid) \\
33 & $13 / 05 / 2008$ & Ministerio de Asuntos Exteriores (Madrid) \\
34 & $13 / 05 / 2008$ & Secretaría de Inmigración (Madrid) \\
35 & $13 / 05 / 2008$ & Colegio de Abogados de Madrid (Madrid) \\
36 & $13 / 05 / 2008$ & PSOE (Madrid) \\
37 & $30 / 05 / 2008$ & Employer of a domestic worker (Barcelona) \\
\hline
\end{tabular}




\section{Annex 5: Graph of immigration trends by nationality in Spain}

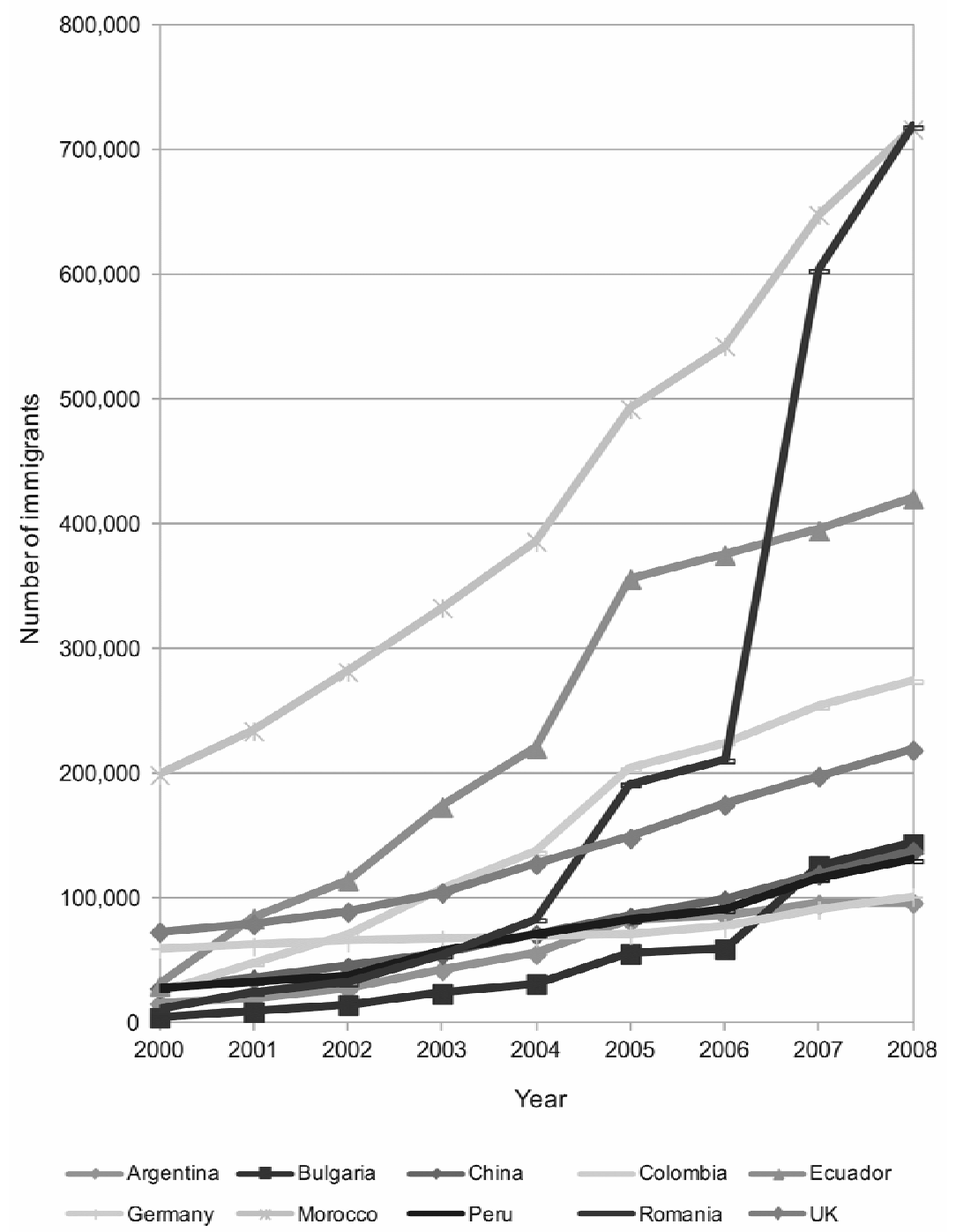

Sources: Ministry of Interior (2000: 27: 2001: 102; 2002: 107-108; 2003:165-166); Ministry of Labour and Social Affairs (2004: 191-192; 2005: 78; 2006: 154; 2007: 189; 2008: 167) 


\section{Notes}

\section{Chapter 1}

I As Portes (I977: 33-34) pointed out, United States immigration policies that have historically benefited capital are not the consequence of a 'political stranglehold exercised by a particular group' (in this case, employers), but rather are determined by 'the latent structure of economic relationships and related political concerns'. Calavita (I984: I2) puts it similarly: [T] he objective relation between capitalism and the state is based on the fact that the capitalist state's function is, and must be, that of actively perpetuating the political economy, so that ultimately the state's interests and the long-term interests of capital are similar.

2 Calavita shows how the INS promoted the Bracero Program as a way to realise its own agenda of reducing illegal migration. At the same time, this policy was contested by the US Department of Labour, which was pressed by organised labour to impose restrictions on the contract system. In Calavita's (I992: IO) words: "Ultimately the two agendas were forced to present a "united front", to compromise, and to coordinate their policies, but they did so reluctantly and only after sometimes prolonged and hostile negotiation.'

3 Noiriel (I99I) describes in historical terms how French citizens became more interested in national politics and started to claim preferential treatment for themselves (including access to work and welfare) vis-à-vis foreigners when they were given the vote. Hence, it would seem that the exclusion of foreigners was encouraged by the process of state formation and democratisation within the state.

4 In the I920s and I930s, the French government negotiated directly with foreign governments, concluding agreements with Poland, Czechoslovakia and Italy. Although formally not part of a guestworker programme, these agreements meant increased state intervention in immigration matters to channel workers into jobs where they would not be directly competing with natives, to reduce competition among employers for scarce labour and to mollify the governments of sending countries that began insisting on protecting the working and living conditions of their nationals (Cross I983). In this regard, these agreements foreshadowed the post-World War II guestworker programmes.

5 This coincides with what Portes (I977:34) observed several decades earlier, stating: 'The more immigrants acquire a legitimate foothold in the host society, the less advantageous their presence is and the more they come to resemble the native proletariat. Conversely, the more they can be kept at the political fringes of the society, the more useful they are in fulfilling significant functions for the economy.'

6 Migration tends to take place during active professional years. This means that, in many cases, the costs of social reproduction remain in the countries of origin.

7 This refers to what have recently been called forms of 'informal citizenship'. 
Sassen (2002: 282) puts it as follows: 'Certain dimensions of citizenship, such as strong community ties and participation in civic activities, are being enacted informally through these [mainly migrants'] practices. These practices produce an at least partial recognition of the individuals as full social beings.' Sassen thus concludes that some degree of citizenship is partly produced by the practices of the excluded. Although this approach has contributed important insights concerning the limited yet relevant set of rights granted to (or asserted by) illegal migrants, it has also been criticised for emphasising 'postmodern' practical citizenship and ignoring forms of exclusion. In Varsanyi's (2006: 138) words: 'For instance, imagine saying to an "illegal immigrant" who is robbed on the way home from work but is scared to contact the police for fear of deportation that he should not be thinking of citizenship as "merely" a "legal right" but should rather be thinking of it as a "practice" or "identity".

\section{Chapter 2}

I As shown both by Groenendijk and Hampsink (1995) and De Lange (2007), the demand for immigrant labour did not disappear after I973. This need for foreign labour was met by immigrants from the former colonies, family migrants, asylum seekers, new temporary labour migrants and illegal migrants.

2 This Western bias and its effect on theory has been criticised particularly by historians. Mongia (2005), for instance, has pointed to an urgent need for migration studies to abandon Eurocentric models. In her view, the idea that the widespread state control of migration is a distinctly twentieth-century phenomenon (Caestecker I998; Lucassen I998; Mullan I998) ignores the fact that, as historians working in the field have repeatedly noted, indentured Indian migration was a state-regulated and state-managed system. McKeown (in Lucassen 2007) has contested the idea that mass migration across the Atlantic during the nineteenth century was unique, as many Western scholars seem to assume. Contrary to mainstream assumptions, he argues that the greater part of labour migrants in Asia at that time consisted of free migrants and that their reasons for moving were similar to those of migrants in Europe today.

3 This workshop was funded by the Asia-Europe Foundation and the Asia Alliance, and organised by Professor Shamsul and myself with the support of the Institute for Migration and Ethnic Studies (University of Amsterdam), the Centre for Migration Law (Radboud University of Nijmegen) and the Institute of Occidental Studies (University Kenbangsaan Malaysia).

4 This does not differ very much from the situation of most European countries until the I970s or I980s. Although policies nowadays are usually published, administrative procedures continue to be treated as 'confidential' or 'internal'. This means that the specific requirements (for instance, becoming 'regularised' in Spain) can only be known by analysing administrative practices. 


\section{Chapter 3}

I In I970, Malays, even though they comprised about 50 per cent of the population, owned less than 2.5 per cent of share capital. Other Malaysians (mainly Chinese and Indians) owned 32.3 per cent and foreigners, 63.3 per cent (Chin I998: 56).

2 It is difficult to give data on gender since the variable is missing both in the academic literature and official statistics. When academic literature does focus on gender, it is mainly on women, alone, rather than a comparison of both sexes and, in most cases, it refers to domestic workers or trafficking. Second, official statistics and reports systematically ignore gender as a variable. For instance, the government-issued 'Report on the impact of foreign workers in the Malaysian economy' (2004) provides the number of legal and illegal migrant workers, their nationality, occupational categories, location, skill levels and duration of employment, but no data regarding the numbers or work characteristics of female and male migrant workers.

3 Proponents of the concept of consociationalism argue that it represents the only effective way of organising democracy in an ethnically plural society. At the same time, it is commonly accepted that the kind of democratic institutions it generates have certain features that are intrinsically anti-democratic. For instance, decisionmaking takes place through secret negotiations within the grand coalition. This means that consociational democracy contains significant elements of elite control, the political decisions being monopolised by an exclusive coalition (Lijphart I969: 213). This leads Brown (2002: 2I4) to argue that the ethnically consociational state should be rather understood in terms of class: '[T]he post-colonial Malaysian state was the result of the alliance between bourgeois class fractions through the political institutions of an alliance between racial groups, in which subordinate racial class fractions were persuaded to ally with dominant racial class fractions within patronage parties structured on avowedly ethnic communal lines.' 'These programmes were launched by the NEP, endeavouring to restructure society by dismantling the identification of ethnicity with economic function and geographic space. Actions included the introduction of quotas for the public and private employment of Malays and the creation of the Bumiputera Commercial and Industrial Community (BCIC). Bumiputera literally means 'sons of the soil', a category that encompasses Malays and the country's other indigenous peoples.'

5 Although gradually changing due to the employment quotas implemented under the NEP, Malays still dominate public-sector unions, such as those pertaining to civil defence and agriculture. The percentage of non-Malays is higher in privatesector unions in the banking and service sectors. Indians dominate union membership in the plantation sector (Chin 2000: 1045).

6 These organisations are primarily concerned with sheltering migrant workers and providing them with legal support. Voicing discontent through their press releases and at conferences, the organisations push the government for comprehensive policies on recruitment procedures, the monitoring of local recruiters, equal treatment between non-citizens and citizens and the development of support mechanisms.

7 The concept of 'Asian values' came into vogue in the I990s, referring to a unique set of Asian institutions and political ideologies. The concept was particularly popular in Malaysia, Singapore, Indonesia and India. Although there is no clear single definition, upholders of Asian values refer to the following: a predisposition for strong, stable leadership rather than political pluralism; respect for social 
harmony and an inclination towards consensus as opposed to a tendency towards dissent or confrontation; acceptance of wide-ranging and thoroughgoing state and bureaucratic intervention in social and economic affairs; concern for socio-economic well-being instead of civil liberties and human rights; and preference for the welfare and collective food security of the community over individual rights.

8 On the trial of Irene Fernandez, see section 3.7.I in this chapter.

9 The present exchange rate for the Malaysian ringgit (RM) (May 20II) is I EUR = 4.33 RM. The family average income is 3,000 RM per month. Although Malaysia has no comprehensive law on minimum wage, in 2009 , some 30,000 plantation workers nationwide received a minimum wage of RM500-600 per month (The Malaysian Insider 6 June 2009).

Io A few years later, in 2003, the Malaysian government attempted to restrict the employment of domestic workers to households in which both parties shared religious beliefs. The aim of this regulation was to restrict employment of Muslim domestic workers to Muslim households. As stated in local newspapers, the purpose was 'Muslim maids for Muslim households' (The Sun I5 April 2003). However - again following (Chinese) employers' protests - this 'same-religion rule' was withdrawn immediately after its announcement. Employers' main concern, as observed by Tokunaga (2005), was that it would diminish their choices - at the time, about 90 per cent of all legal domestic workers were Indonesian and most of them Muslim - in the purchase of care services. There also existed concerns that this new regulation could threaten Malaysia's 'multiracial society' and its goals for pluralistic integration.

II According to the public relations officer of the Immigration Department, the security bond can only be refunded to the employers after showing proof that their workers have left the country. In 'running away' cases, 'the employer must lodge a police report and a copy of the report must be filed with the department for its enforcement officers to try and locate the worker.' Money collected through the security bond 'will finance the cost of deporting any worker who fails to adhere to the conditions stipulated in his temporary employment pass' (New Sunday Times I5 November I992).

I2 As often stated by the Immigration Department, money earned through the levy has often exceeded all these costs. For instance, while in 1994 the government collected RM 276 million from levies imposed on migrant workers, the Immigration Department's expenditure only totalled RM 77 million (New Sunday Times 6 February 1994). In 1998, money obtained through levies on migrant workers came to RM 4I5 million (Department of Immigration 1998). Referring to these amounts, a lawyer from the bar council was of the opinion that 'The levy is just government revenue and they make a lot of money with it' (interview II October 2006, Kuala Lumpur).

I3 In 2006, grave human rights violations relating to RELA activities were denounced in the press and by many human rights organisations. For instance, on II February 2006 , the BBC reported that five bodies had been retrieved from a lake in Selayang after undocumented migrants allegedly tried to flee a RELA raid. Other violations include the detention of refugees with UNHCR-recognised status, asylum seekers, newborn babies, children and pregnant women. As denounced by the human rights organisation SUARAM: 'Cases revealed a consistent pattern of theft, deliberate damage to properties, physical assault, humiliation and degrading treatment of suspected "illegal immigrants"' (SUARAM 2006). 


\section{Chapter 4}

I The HDI measures the average achievements in a country along three basic dimensions of human development: I) a long and healthy life, as measured by life expectancy at birth; 2) knowledge and education, as measured by the adult literacy rate (with a two-thirds weighting) and the combined primary, secondary and tertiary gross enrolment ratio (with a one-third weighting); and 3) decent standard of living, as measured by the natural logarithm of GDP and purchasing power parity (PPP) in US dollars.

2 The Czech Republic, Estonia, Hungary, Latvia, Lithuania, Poland, Slovakia, Slovenia, Malta and Cyprus joined the EU in May 2004. Romania and Bulgaria followed in January 2007 . For those migrants without a residence permit, becoming EU citizens meant sudden legality. This was particularly the case for Romanians and Bulgarians citizens in Spain on I January 2007.

3 Contemporary historical research has shown that actual cases of 'white slavery' were very few (Doezema 2000). In her interesting article on the rumour of trafficking and border controls, irregular migration and nation-state sovereignty, Wong (2006) observes a strong parallelism between the white slavery scare that raged (particularly in the UK and the US) at the turn of the last century and the current discourse on 'human trafficking'. According to Wong (ibid.: 73): 'both discourses were centered around the issue of prostitution and female migration. Both shared the motif of innocent victimhood, as well as a similar absence of material basis to the enraged claims of the virulence and scale of the phenomena'. Moreover, both cases show an enormous amount of transnational state interventionism and 'political and social boundary-maintenance' (ibid.: 70). The difference is that, while at the beginning of the twentieth century this discourse was meant to keep wanted citizens in, at the end of the twentieth century, it was meant to keep unwanted foreigners out.

4 Illegality among Spanish migrants should also be explained by the situation in countries of destination. To illustrate, Pereira (2007: 13) observes how, in the French case, employers saw illegal migrants as an advantage, not only because they offered cheaper labour, but also because their illegality enabled circumventing what were perceived as inadequate immigration laws. As shown in the Spanish case some decades later, employers saw the legal immigration process as being too slow and expensive. Moreover, they preferred to choose their employees 'at the factory door', rather than asking the government to recruit workers they did not know and whose skills they could not directly check into.

5 Colombian intellectuals protested, pleading historic ties of solidarity with Spain. Jesús Caldera, a PSOE member and future Minister of Labour and Social Affairs, described the PP government's decisive abstention from voting in the EU Council of Ministers - which made it possible to impose the obligatory visa for Colombians - as a 'shameful and inadmissible attack on Spanish-speaking America' (El País 24 March 200I in Fernández Suárez 2007: 6).

6 As former PP Minister for Labour and Social Affairs (January I999-February 2000) Manuel Pimentel observed: 'Well, yes, the quota was always much lower than the demand in our society and it was used on many occasions to legalise the ones that were already here. So it wasn't much use in terms of its initial function, which was to regulate the entry of people. This insufficient quota, combined with the exasperating slowness of the Régimen General has had a distressing consequence: almost 85 per cent of the immigrants came in illegally and were subsequently regularised. We know we need 
immigrants but we never established any legal way of entry. Result: we de facto pushed them into illegal channels' (El País 9 March 2002).

7 When the quota for 2002 was announced (the first to be approved since the Laws $4 / 2000$ and $8 / 2000$ ), it was expressly stated that applications processed through the Régimen General would be inadmissible so long as the quota remained open. After numerous protests, several court rulings pronounced this measure illegal both in its formal dimensions (the decision being made by merely announcing the quota) and its content (the law did not stipulate abolishing the Régimen General). As a result, the Régimen General remained open in legal terms, although it was virtually inoperative because the national labour market situation continued to be interpreted in very stringent terms.

8 In the context of Argentina's serious economic crisis during this period, the jobseeking visa for children and grandchildren of Spanish-born people endeavoured to open up a possibility for second- and third-generation Spaniards to emigrate to Spain. Nonetheless, the measure was more symbolic than anything else, first, because many later-generation Spaniards still kept or applied for Spanish (or, in other cases, Italian) citizenship and thus had all the rights of European citizens; second, even though 500 of these visas were offered in 2007, the Ministry of Labour and Social Affairs acknowledged how not a single such visa was issued. According to the Migration Department of the Confederación Intersindical Galega (Galician Union Federation, CIG), Spanish consulates in Argentina were not processing them due to a lack of information about the procedure (see the Zaragoza Lawyers Institute's Extranjería webpage concerning foreigners and aliens: www.intermigra.info/extranjeria/modules.php?name=News\&file=article\&sid=I304; last accessed I5 April 2008.)

9 The term 'arraigo' is used quite indiscriminately in official circles to refer, rather loosely, to employment stability or social consolidation. I shall henceforth indicate, where possible, the sense in which it is used.

Io Referring to one NGO, a Congolese immigrant in Madrid stated: 'No, they didn't let me [apply for a permit] because even though I've been here a long time and they know it because they'd seen me and because I'd gone there before, I didn't have good documents so I couldn't present. And now I'm sorry because I see that a lot of people got it [a permit], even without papers because I know about plenty of people who are getting it and they haven't got papers' (in Arango \& Suárez Navaz 2002: 500).

II As spokeswoman of the Ecuadorian organisation Rumiñahui Dora Aguirre pointed out: '[...] the only thing the Ecuadorian does is to orientate himself towards the madre patria in order to escape from the poverty in our country. And he comes for reasons of kinship, language and history' (La Opinión I4 January $200 \mathrm{I}$ in Laubenthal 2007: II7). Another example is the highly publicised action of a collective blood donation that aimed to show to 'the Spanish society our will to integrate ourselves and to collaborate in everything' ( $L a$ Verdad 22 January 200I). As one immigrant voiced out: 'I give you my blood, what more do you ask for?' (El País 8 February 200I).

I2 SOS Racismo (2004: 3) criticised the government as follows: 'The government has not heeded the background ideas expressed by the associative movement. It has limited itself to just one, which is that of adopting an extraordinary measure. This, in turn, has shifted things into the domain where illegality has one main cause and that is the black economy and the illegal job offer in the Spanish economy [...]. Without underestimating this issue, which is the subject of many different discussions, although also a theme much loved by the unions, we feel that this is a one-sided standpoint when it comes to analysing the causes of illegality.' 
I3 Caldera was referring to 'Communication 4I2' (June 2004), a document on the links between legal and illegal migration. As Ferrero and Pinyol (2007: 9) remarked in assessing both positive and negative aspects of the regularisation programmes, this document dodged making a definitive statement on the matter.

I4 This situation seems to have pertained particularly to men who were regularised in the domestic service sector with the aim of achieving regularisation directly (not through their employer) and without a formal contract. If they did not subsequently find work in the same sector and province or keep up social security payments while working on the black market, renewal procedures implied falling back into illegality after a year.

I5 The fact that chances for regularisation via arraigo social depended, at least in part, on a local town council-issued report of an immigrant's social integration (specifying his or her duration of residence, means of support, extent of knowing the official language or languages, degree of participation in social networks and training programmes, enzovoort) once again accords a high degree of discretionary judgement and variation to the territory.

I6 This relationship has to be proven by way of a judicial or administrative decision by the Department of Labour Inspection. To achieve this, the foreign worker must denounce the employer for his or her working - or having been working - illegally, or sue the employer in court for dismissal or non-payment of salary. As Aguilera Izquierdo (2006: I9I) notes, the main problem, given the absence of documents (written contract, payslips, social security registration) is to prove the duration of the employment relationship. Often the only chance is thus via a declaration by witnesses, which is deemed to be inherently weak, both in the social order courts and in the employment administration.

I7 Curiously, although the permit obtained through regularisation does not depend on the general situation of the job market, the initial stay is limited to the characteristics of the job that makes the regularisation possible.

I8 Using an original administrative-based dataset from the government sub-delegate's office, Sabater and Domingo (2010) conclude that in the province of Barcelona, over I,000 new migrants applied for arraigo laboral (852 granted) and over 47,000 applied for arraigo social (31,328 granted) between January 2006 and December 2009 .

I9 To obtain regularised status in the 2005 process it was necessary to be registered in el Padrón prior to 8 August 2004. Those who registered too late could obtain regularisation through arraigo social three years later, which is to say after 8 August 2007.

20 Cause for expulsion under the LOE included: I) being in Spain illegally; 2) working without a work permit, even if holding a resident's permit; 3) being engaged in activities counter to public order or domestic and foreign security; 4) being prior convicted for certain crimes; 5) concealing, in certain cases, information pertaining to changes in personal situation; and/or 6) lacking lawful means of support, engaging in mendacity or other illegal activities. With the new regulation of 1996, infractions and sanctions were graded under headings of slight, serious or very serious, by which means it was possible to avoid indiscriminate expulsion for any type of infraction.

2I In 2004, deportation costs were $€ 6,750$ for Chinese citizens, $€ 3,834$ for Ecuadorians and $€ 2,000$ for Senegalese (El País 27 May 2004).

22 This law stipulates a fine or expulsion order as the penalty for illegal residence, depending on the personal circumstances of the foreigner. Although several court 
rulings have confirmed that illegal presence in the country should be subject to a fine rather than expulsion, it is in fact systematically penalised with an expulsion order (interviews with lawyers I8 December 2007 and 8 April 2008, Barcelona).

23 In 2008, the maximum custody length in member states was as follows: 32 days (France, Cyprus), 40 days (Italy, Spain), eight weeks (Ireland), 6o days (Portugal), three months (Luxembourg, Greece), six months (Slovenia, Slovakia, Czech Republic, Hungary, Romania), eight months (Belgium), ten months (Austria), twelve months (Poland), eighteen months (Malta, Germany), twenty months (Latvia) and unlimited duration (Denmark, Estonia, Finland, Lithuania, the Netherlands, the UK, Sweden). The data are obtained from the European Parliament website (www.europarl.europa.eu/sides/getDoc.dotype=IMPRESS\&reference $=20080609$ BKG31068\&language $=E N$; last acceded 16 December 2009).

24 In 2007 , fewer expulsion orders were carried out than in 2006 , partly because Romanians and Bulgarians became European citizens in 2007 and were thus no longer deportable.

25 According to Girona's immigration office, 6,750 travellers were turned back each month at the La Jonquera border in 2004. The figure dropped to 3,700 in 2006 while, in 2007, it was only 200 . In 2004,80 per cent of the people turned back were Romanians and 15 per cent were Bulgarians. At present, the average figure of 200 people turned back each month at this border crossing comprises some 50 nationalities (El País 5 January 2008).

26 In May 2006, Spain's repatriation of 99 Senegalese and the resulting protests led the Senegalese government - then in the middle of its electoral campaign - to suspend return of the immigrants. 


\section{Other IMISCOE titles}

\section{IMISCOE Research}

Rinus Penninx, Maria Berger, Karen Kraal, Eds.

The Dynamics of International Migration and Settlement in Europe: A State of the Art

2006 (ISBN 9789053568668 )

(originally appearing in IMISCOE Joint Studies)

Leo Lucassen, David Feldman, Jochen Oltmer, Eds.

Paths of Integration: Migrants in Western Europe (1880-2004)

2006 (ISBN 978905356883 5)

Rainer Bauböck, Eva Ersbøll, Kees Groenendijk, Harald Waldrauch, Eds. Acquisition and Loss of Nationality: Policies and Trends in 15 European Countries, Volume 1: Comparative Analyses

2006 (ISBN 9789053569207 )

Rainer Bauböck, Eva Ersbøll, Kees Groenendijk, Harald Waldrauch, Eds. Acquisition and Loss of Nationality: Policies and Trends in 15 European Countries, Volume 2: Country Analyses

2006 (ISBN 978905356 92I 4)

Rainer Bauböck, Bernhard Perchinig, Wiebke Sievers, Eds.

Citizenship Policies in the New Europe

2007 (ISBN 978905356922 I)

Veit Bader

Secularism or Democracy? Associational Governance of Religious Diversity 2007 (ISBN 9789053569993 )

Holger Kolb, Henrik Egbert, Eds.

Migrants and Markets: Perspectives from Economics and the Other Social

Sciences

2008 (ISBN 9789053566848 )

Ralph Grillo, Ed.

The Family in Question: Immigrant and Ethnic Minorities in Multicultural Europe

2008 (ISBN 9789053568699 ) 
Corrado Bonifazi, Marek Okólski, Jeannette Schoorl, Patrick Simon, Eds. International Migration in Europe: New Trends and New Methods of Analysis 2008 (ISBN 978905356894 I)

Maurice Crul, Liesbeth Heering, Eds.

The Position of the Turkish and Moroccan Second Generation in Amsterdam and Rotterdam: The TIES Study in the Netherlands 2008 (ISBN 978908964 o6I I)

Marlou Schrover, Joanne van der Leun, Leo Lucassen, Chris Quispel, Eds. Illegal Migration and Gender in a Global and Historical Perspective 2008 (ISBN 9789089640475 )

Gianluca P. Parolin

Citizenship in the Arab World: Kin, Religion and Nation-State 2009 (ISBN 978908964045 I)

Rainer Bauböck, Bernhard Perchinig, Wiebke Sievers, Eds. Citizenship Policies in the New Europe: Expanded and Updated Edition 2009 (ISBN 978908964 I08 3)

Cédric Audebert, Mohamed Kamel Dorai, Eds.

Migration in a Globalised World: New Research Issues and Prospects 20I0 (ISBN 978908964 I57I)

Richard Black, Godfried Engbersen, Marek Okólski, Cristina Pantîru, Eds. A Continent Moving West? EU Enlargement and Labour Migration from Central and Eastern Europe 20I0 (ISBN 978908964 I56 4)

Charles Westin, José Bastos, Janine Dahinden, Pedro Góis, Eds. Identity Processes and Dynamics in Multi-Ethnic Europe 20IO (ISBN 9789089640468 )

Rainer Bauböck, Thomas Faist, Eds. Diaspora and Transnationalism: Concepts, Theories and Methods 20I0 (ISBN 978908964238 7)

Liza Mügge

Beyond Dutch Borders: Transnational Politics among Colonial Migrants, Guest Workers and the Second Generation 20IO (ISBN 9789089642448 ) 
Peter Scholten

Framing Immigrant Integration: Dutch Research-Policy Dialogues in Comparative Perspective

2OII (ISBN 9789089642844 )

Albert Kraler, Eleonore Kofman, Martin Kohli, Camille Schmoll, Eds.

Gender, Generations and the Family in International Migration

2OII (ISBN 978908964285 I)

Michael Bommes, Giuseppe Sciortino, Eds.

Foggy Social Structures: Irregular Migration, European Labour Markets and the Welfare State

2OII (ISBN 978908964 34I 4)

Giovanna Zincone, Rinus Penninx, Maren Borkert, Eds.

Migration Policymaking in Europe: The Dynamics of Actors and Contexts in Past and Present

2OII (ISBN 9789089643704 )

Marcel Maussen, Veit Bader, Annelies Moors, Eds.

Colonial and Post-colonial Governance of Islam: Continuities and Ruptures 2OII (ISBN 978908964356 8)

Bram Lancee

Immigrant Performance in the Labour Market: Bonding and Bridging Social Capital 2OII (ISBN 9789089643575 )

Julie Vullnetari

Albania on the Move: Links between Internal and International Migration 2OII (978 90 8964 355 I)

\section{IMISCOE Reports}

Rainer Bauböck, Ed.

Migration and Citizenship: Legal Status, Rights and Political Participation 2006 (ISBN 978905356888 o)

Michael Jandl, Ed.

Innovative Concepts for Alternative Migration Policies:

Ten Innovative Approaches to the Challenges of Migration in the 21st Century 2007 (ISBN 978905356990 o) 
Jeroen Doomernik, Michael Jandl, Eds.

Modes of Migration Regulation and Control in Europe

2008 (ISBN 978905356689 3)

Michael Jandl, Christina Hollomey, Sandra Gendera, Anna Stepien,

Veronika Bilger

Migration and Irregular Work In Austria: A Case Study of the Structure and Dynamics of Irregular Foreign Employment in Europe at the Beginning of the 21st Century

2008 (ISBN 9789089640536 )

Heinz Fassmann, Ursula Reeger, Wiebke Sievers, Eds.

Statistics and Reality: Concepts and Measurements of Migration in Europe 2009 (ISBN 9789089640529 )

Karen Kraal, Judith Roosblad, John Wrench, Eds.

Equal Opportunities and Ethnic Inequality in European Labour Markets

Discrimination, Gender and Policies of Diversity

2009 (ISBN 978908964 I26 7)

Tiziana Caponio, Maren Borkert, Eds.

The Local Dimension of Migration Policymaking

20I0 (ISBN 978908964232 5)

Raivo Vetik, Jelena Helemäe, Eds.

The Russian Second Generation in Tallinn and Kohtla-Järve: The TIES Study in Estonia

20I0 (ISBN 9789089642509 )

\section{IMISCOE Dissertations}

Panos Arion Hatziprokopiou

Globalisation, Migration and Socio-Economic Change in Contemporary

Greece: Processes of Social Incorporation of Balkan Immigrants in

Thessaloniki

2006 (ISBN 9789053568736 )

Floris Vermeulen

The Immigrant Organising Process: Turkish Organisations in Amsterdam and Berlin and Surinamese Organisations in Amsterdam, 1960-2000 2006 (ISBN 978905356875 o) 
Anastasia Christou

Narratives of Place, Culture and Identity: Second-Generation

Greek-Americans Return 'Home'

2006 (ISBN 978905356878 I)

Katja Rušinovic

Dynamic Entrepreneurship: First and Second-Generation Immigrant

Entrepreneurs in Dutch Cities

2006 (ISBN 9789053569726 )

Ilse van Liempt

Navigating Borders: Inside Perspectives on the Process of Human Smuggling

into the Netherlands

2007 (ISBN 9789053569306 )

Myriam Cherti

Paradoxes of Social Capital: A Multi-Generational Study of Moroccans

in London

2008 (ISBN 978905356032 7)

Marc Helbling

Practising Citizenship and Heterogeneous Nationhood: Naturalisations

in Swiss Municipalities

2008 (ISBN 978908964034 5)

Jérôme Jamin

L'imaginaire du complot: Discours d'extrême droite en France et aux Etats-Unis 2009 (ISBN 978908964048 2)

Inge Van Nieuwenhuyze

Getting by in Europe's Urban Labour Markets: Senegambian Migrants'

Strategies for Survival, Documentation and Mobility

2009 (ISBN 9789089640505 )

Nayla Moukarbel

Sri Lankan Housemaids in Lebanon: A Case of 'Symbolic Violence' and 'Every Day Forms of Resistance'

2009 (ISBN 978908964 05I 2)

John Davies

'My Name Is Not Natasha': How Albanian Women in France Use

Trafficking to Overcome Social Exclusion (1998-2001)

2009 (ISBN 9789053567074 ) 
Dennis Broeders

Breaking Down Anonymity: Digital Surveillance of Irregular Migrants

in Germany and the Netherlands

2009 (ISBN 978908964 I59 5)

Arjen Leerkes

Illegal Residence and Public Safety in the Netherlands

2009 (ISBN 978908964049 9)

Jennifer Leigh McGarrigle

Understanding Processes of Ethnic Concentration and Dispersal:

South Asian Residential Preferences in Glasgow

2009 (ISBN 978905356 67I 8)

João Sardinha

Immigrant Associations, Integration and Identity: Angolan, Brazilian

and Eastern European Communities in Portugal

2009 (ISBN 9789089640369 )

Elaine Bauer

The Creolisation of London Kinship: Mixed African-Caribbean and White British

Extended Families, 1950-2003

2010 (ISBN 978908964235 6)

Nahikari Irastorza

Born Entrepreneurs? Immigrant Self-Employment in Spain

20I0 (ISBN 978908964243 I)

Marta Kindler

A Risky Business? Ukrainian Migrant Women in Warsaw's Domestic Work Sector 2OII (ISBN 9789089643278 )

\section{IMISCOE Textbooks}

Marco Martiniello, Jan Rath, Eds.

Selected Studies in International Migration and Immigrant Incorporation 20I0 (ISBN 978908964 I60I) 